\title{
Proposed Industrial Recovered Materials Utilization Targets for the Metals and Metal Products Industry
}

MASTER

May 1979

Prepared for:

U.S. Department of Energy

Assistant Secretary for Conservation and Solar Applications

Office of Industrial Programs

Under Contract No. EC-77-C-03-1692

\section{RECEIVED}

DFC 181980

DOE OFFICE OF PAMENT 


\section{DISCLAIMER}

This report was prepared as an account of work sponsored by an agency of the United States Government. Neither the United States Government nor any agency Thereof, nor any of their employees, makes any warranty, express or implied, or assumes any legal liability or responsibility for the accuracy, completeness, or usefulness of any information, apparatus, product, or process disclosed, or represents that its use would not infringe privately owned rights. Reference herein to any specific commercial product, process, or service by trade name, trademark, manufacturer, or otherwise does not necessarily constitute or imply its endorsement, recommendation, or favoring by the United States Government or any agency thereof. The views and opinions of authors expressed herein do not necessarily state or reflect those of the United States Government or any agency thereof. 


\section{DISCLAIMER}

Portions of this document may be illegible in electronic image products. Images are produced from the best available original document. 
This document was prepared by Arthur D. Little, Inc. under direction by the Office of Industrial Programs, Office of lhe Assistant Secretary for Conservation and Solar Applications, U.S.

Department of Energy. The analysis and determinations indicated in this document have been used as a basis to propose recovered materials utilization targets for the metals and metal product industry. This target is required to be established by Section 374A of the Energy Policy and Conservation Act as amended by the National Energy Conservation Policy Act. 


\section{Proposed Industrial Recovered Materials Utilization Targets for the Metals and Metal Products Industry}

May 1979

Prepared by:

Arthur D. Little, Inc.

Cambridge, Mass.

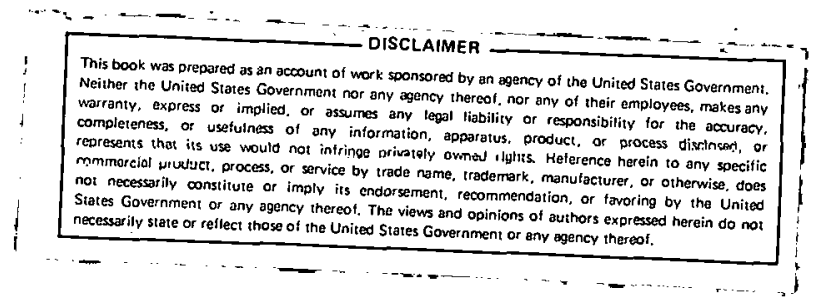

Prepared for:

U.S. Department of Energy

Assistant Secretary for Conservation

and Solar Applications

Office of Industrial Programs

Washington, D.C. 20585

Under Contract No. EC-77-C-03-1692 
PRINCIPAL PARTICIPANTS IN THE STUDY

Bennett Bovarnick (Consultant)

Kirkor Bozdogan

Glenn DeSouza

Kurt Doelling

Jane Gray

Richard Hyde

David Kinneberg

David Kleinschmidt

Raymnnd Marhacek

Stanley Margolin

- Sliasliarik Nadgauda.

Edvard Uhlsson

Charles $\Omega^{\prime}$ Neil

Krishna Parameswaran

David Wheeler (Consultant)

Asslstant Prujecl Diıeclür, Subhash Malhotra

Project Director, Ravindra Nadkarni

DOE Technical Project Officer, Lewis Newmar. 
List of Tables

Page

vii

List of Figures

xi

1.0 SUMMARY

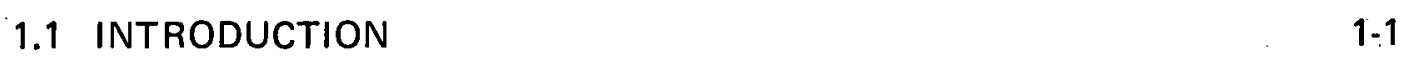

1.2 PURPOSE AND SCOPE $1-1$

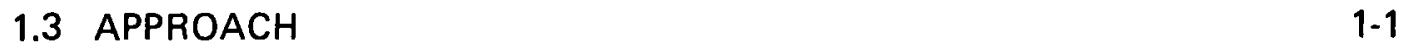

1.4 FINDINGS $1-2$

1.4.1 General Discussion of Metals Recycling 1-2

1.4.2 Economics of Scrap Recycling 1-4

$\begin{array}{lll}1.4 .3 & \text { Ferrous Industry } & 1-6\end{array}$

$\begin{array}{ll}1.4 .4 \text { Aluminum Industry } & 1-7\end{array}$

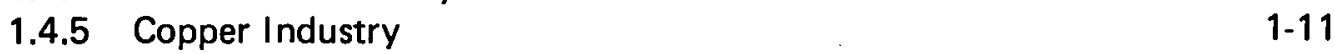

$\begin{array}{ll}\text { 1.4.6 Zinc Industry } & 1-114\end{array}$

$\begin{array}{lr}1.4 .7 \text { Lead Industry } & 1-19\end{array}$

1.5 IMPACT OF GOVERNMENT ACTIONS ON RECYCLING

2.0 INTRODUCTION $2-1$

2.1 GENERAL DISCUSSION OF METALS RECYCLING 2-1

2.1.1 Resource Characteristics 2-1

2.1.2 Industry Techinology 2-3

2.1.3 Pollution Control 2-3

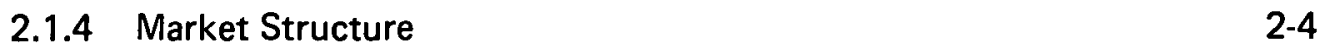

2.1.5 Economics of Scrap Recycling 2-4

2.1.6 Econometric Estimates of Scrap Supply Elasticity 2-6

$\begin{array}{lr}2.2 \text { METHODOLOGY } & 2-10\end{array}$

2.2.1 Mẹthodology Overview 2-10

2.3 IMPACT OF GOVERNMENT ACTIONS ON RECYCLING 2-15

REFERENCES $\quad 2-16$ 
3.1.1 Definition of SIC 33

3.1.2 Subdivision of SIC 33 by Industry Groups

3.2 FERROUS 3-2

3.2.1 Industry Definition

3.2.2 Industry Structure

3.2.3 Process Technology

3.2.4 Materials Flow

3.2.5 Future Trends

3.3.1 Industry Definition

3.3.2 Industry Structure

3.3.3 Process Technology

3.3.4 Materials Flow

3-63

3.3.5 Future Trends

3-69

3.4 COPPER

3-69

3.4.1 Industry Definilioun

3.4.2 Industry Structure

3-72

3.4.3 Process Technology

3-79

3.4.4 Materials Flow

3-86

3.4.5 Future Trends

3.5.1 Industry Definition

3.5.2 Industry Structure

3.5.3 Proccss Techuulugy

3-95

3.5.4 Materials Flow

3-95

3.5.5 Future Trends

3.6.1 Industry Definition

3.6.2 Industr.y Structure 


\section{TABLE OF CONTENTS (Continued)}

3.6.3 Process Technology

Page

3.6:4 Materials Flow

3-112

3.6.5 Future Trends

3-117

3-120

REFERENCES

3-122

\subsection{EVALUATION OF RECYCLING TARGETS BY INDUSTRY GROUPS IN SIC 33}

\subsection{INTRODUCTION}

4.1.1 Selection of Recoverable Materials 4-1

4.1.2 Selection of Process Subdivisions for Inclusion in the Target

4-2

4.1.3 Technical Considerations

4-2

4.1.4 Economic Considerations

4-3

4.1.5 Special Considerations

4-3

4.1.6 Target Estimation

4-3

4.1.7 Sensitivity of Target to Key Factors

\subsection{FERROUS}

$4-4$

4.2.1 Selection of Recoverable Materials

4.2.2 Selection of Process Subdivisions for Inclusion in the Target

4.2.3 Technical Considerations

4-22

4.2.4 Economic Considerations

4.2.5 Special Considerations

4.2.6 Target Estimation

4-51

4.2.7 Sensitivity of Targets to Key $\Gamma$ actors

4-55

\subsection{ALUMINUM}

4.3.1 Selection of Recoverable Materials

4-60

4.3.2 Selection of Process Subdivisions for Inclusion in the Target

4.3.3 Technical Considerations

4-65

4.3.4 Economic Considerations

4-67

4.3.5 Special Considerations

4-75

4.3.6 Target Estimation

4.76

4.3.7 Sensitivity of Target to Key Factors

4-78 


\section{TABLE OF CONTENTS (Continued)}

Page

$\begin{array}{ll}\text { 4.4 COPPER } & \mathbf{4 - 8 0}\end{array}$

4.4.1 Selection of Recoverable Materials $\quad 4-80$

4.4.2 Selection of Process Subdivisions for Inclusion in the Target 4-84

4.4.3 Technical Considerations $\quad 4-84$

4.4.4 Economic Considerations in Recycling 491

4.4.5 Special Considerations 4 4-93

4.4.6 Target Estimation 4-93

4.4.7 Sensitivity of Target to Key Factors 4-97

4.5 ZINC

4.5.1 Selection of Recoverable Materials $\quad$ 4-98

4.5.2 Selection of Process Subdivisions for Inclusion in the Target 4-100

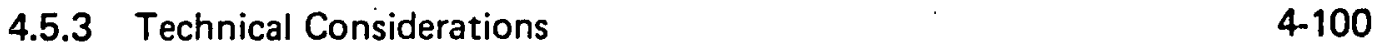

4.5.4 Economic Considerations in Recycling 4-103

4.5.5 Special Considerations 4-104

4.5.6 Target Estimation 4-104

4.5.7 Sensitivity of Target to Key Factors 4-104

4.6 LEAD 4-105

4.6.1 Selection of Recoverable Matcrial3 4-105

4.6.2 Selection of Process Subdivisions for Inclusion in the Target 4-107

4.6.3 Technical Considerations $\quad$ 4-107

4.6.4 Economic Considerations $\quad$ 4-112

$\begin{array}{lr}\text { 4.6.5 Special Considerations } & 4-112\end{array}$

4.6.6 Target Estimation $\quad 4.114$

4.6.7 Sensitivity of Target to Key Factor 4-114

REFERENCES $\quad$ 4-117

BIBLIOGRAPHY B-1 


\section{LIST OF TABLES}

Table No.

Page

1.4-1 Recovered Material Targets for $1987 \quad 1-12$

3.2.1 Raw Steel Production: 1950.1976

3-4

3.2.2 Purchased Energy Use in the Iron and Steel Industry by SIC Category - 1974-1976

Number of Foundries and Casting Shipments - 1976

Ferroalloys Produced and Shipped - 1976

Primary Aluminum Plants - Ranges of Raw Materials and Energy Requirements

3.4-3 Estimated Secondary Refined Copper Produced by Primary and Secondary Producers - 1960-1976

3.4-4 Production of Secondary Copper, Refined and Unrefined Recovered from Purchased Scrap, 1974-1976 


\section{LIST OF TABLES (Continued)}

Table No.

Page

3.5-1 Primary Zinc Smelters - 1976

3.5-2 Secondary Zinc Distillers 3-94

3.5-3 Comparison of Domestic Zinc Production and Demand 1957-1977 and $1985 \quad 3-104$

3.6-1 Lead Consumption by End-Use Market - 1976

3.6-2 Lead Smelters/Refiners 3-108

3.6-3 Integrated Secondary Lead Smelters and Refiners 3-110

3.6-4 Independent Secondary Lead Smelters and Refiners . $\quad 3-111$

3.6-5 Estimated 1987 Lead Consumption : $\quad$ 3-121

4.2-1 Selection of Recoverable Materials - Iron and Steel Segment 4-5

4.2-2 Consumption of Recoverable Materials (1970-1976) 4-7

4.2-3 Consumption of Scrap by Grade (1971-1976) 4-8

4.2-4 Selection of Recoverable Materials - Ferrous Foundry Segment $\quad$ 4-9

4.2-5 Consumption of Recoverable Materials (1971-1976) 4-11

4.2-6 Selection of Recoverable Materials - Ferroalloys Segment 4-12

4.2-7 Consumption of Recoverable Materials (1970-1976) 4-14

4.2-8 Recoverable Material Source - Industry Matrix - Iron and
Steel Segment

4.2-9 Consumption of Recoverable Materials by Process in $1976-$
Iron and Steel Segment

4.2-10-A Consumption of Recoverable Materials by the Sinter Plant
$(1970-1976)$ - Iron and Steel Segment

4.2-10-B Consumption of Recoverable Materials by the Blast Furnace

4.2-10-C Consumption of Recoverable Materials by the Basic Oxygen

4.2-10-D Consumption of Recoverable Materials by the Electric Arc
Furnace (1970-1976) - Iron and Steel Segment

4.2-10-E Consumption of Recoverable Materials by the Open Hearth
Furnace (1970-1976) - Iron and Steel Segment

4.2-11 Consumption of Scrap - 1976 - Ferrous Foundry Segment 4-22

4.2-12 Consumption of Scrap (1971-1976) - Ferrous Foundry

4.2-13 Consumption of Recoverable Materials - 1976 - Ferroalloy 4-24

4.2-14 Distribution of Elements Between Slag and Metal in an Open

4.2-15 Composition Ranges of Iron for Steelmaking 4-30

4.2-16 Ferrous Foundry Specifications 4-31

4.2-17 Ferroalloy Specifications $\quad$ 4-32

4.2-18 Ferrous Scrap Mass Balance - $1976 \quad$ 4-39

4.2-19 Equations of the Ferrous Scrap Model 4-44

4.2-20 Definition of Variables - Ferrous Scrap Model 
LIST OF TABLES (Continued)

Table No.

Page

4.2-21 Definition of Parameters - Ferrous Scrap Model

4-47

4.2-22 Scrap in Furnace Charge as a Percentage of Raw Steel

Production - by Furnace Type (1960-1976): Iron and

Steel Segment

4-49

4.2-23 List of Model Parameters and Assumptions for the Seven

Scenarios Analyzed - Ferrous Industry $\quad \mathbf{4 - 5 2}$

4.2-24 Recycling Ratios for Ferrous Industry for Seven Scenarios - $1987 \quad 4-56$

4.2-25 Recycling Ratios for the Iron \& Steel Segment for Seven

Scenarios - $1987 \quad 4-57$

4.2-26 Recovered Material Target for Ferrous Industry (1987) 4-58

4.2-27 Sensitivity of Targets to Key Factors - Ferrous Industry $\quad 4-59$

4.3-1 Selection of Recoverable Materials - Aluminum Industry 4-61

4.3-2 Consumption of Recoverable Materials by Industry

Subdivision (1970-1976) $\quad$ 4-63

4.3-3 Recoverable Material Source - Industry Matrix - Aluminum
Industry

4.3-4 Aluminum - Composition Limits and Uses of Some Aluminum
Wrought and Casting Alloys

4.3-5 1976 Material Balance for Aluminum Scrap 4-68

4.3-6 Aluminum Can Reclamation Data $\quad$ 4-70

4.3-7 Equations of the Aluminum Scrap Model 4-72

4.3-8 Definition of Variables and Parameters - Aluminum

4.3-9 Values of Parameters Used in Target Evaluation - Aluminum

4.3-10 Recycling Ratios for Aluminum Industry for Four Scenarios - 1987 4-79

4.3-1.1 Recovered Material Target for Aluminum Industry - $1987 \quad 4-79$

4.3-12 Sensitivity of Targets to Key Factors - Aluminum Industry

4.4-1 Selection of Recoverable Materials - Copper Industry 4-82

4.4-2 Recoverable Material - Suurce - Industry Matrix -
Copper Industry

4.4-3 Consumption of Recoverable Materials 1976 - Copper Industry 4-86

4.4-4 Price/Quantity Data for Recoverable Materials (1970-1976) -
Copper Industry

4.4-5 Consumption of Recoverable Material 1970-1976 - Copper
Industry

4.4-6 Copper Production by Refineries (by Input Source), 1974-1976 4-92

4.4-7 Histnrica! Recycling Data - 1970-1876 Copper Industry 4-94

4.4-8 Copper Industry Estimated Increase (1974-1987) 4-95

4.4-9 Recovered Material Target for Copper Industry (1987) 4-95

4.4-10 Copper Recycling Ratios, 1970-1976 4-96

4.5-1 Selection of Recoverable Materials - Zinc Industry 4-99

4.5-2 Recoverable Material - Source - Industry Matrix - Zinc Industry 4-101 


\section{LIST OF TABLES (Continued)}

Table No.

Page

4.5-3 Consumption of Recoverable Materials - 1976 4-102

4.5-4 Recovered Material Target for Zinc Industry

4-105

4.6-1

Selection of Recoverable Materials - Lead Industry

4-106

4.6-2

Scrap Consumption in the Lead Industry (1970-1976)

4-108

4.6-3

Standard Specifications for Pig Lead

4-110

4.6-4

Composition of Lead Alloys

4-111

4.6-5

Recovered Material Target for Lead Industry

4-115 


\section{LIST OF FIGURES}

Figure No.

Page

$2 \cdot 1$

An Illustration of the Simultaneity Problem

Methodology Network Energy Saving Recovered Materials

Targets

2-11

$2 \cdot 3$

Recoverable Materials Sources - Industry Subdivision Matrix

2-13

Pictorial Representation of Process Unit Interrelationships -

Process Flow Diagram of a Typical Foundry

Schematic Illustration of an Integrated Manganese

Smelting and Refining Facility

Materials Flow in the Iron and Steel Industry - 1976

Materials Flow - Ferrous Foundries

Flow Diagram in the Ferroalloys Industry 


\subsection{SUMMARY}

\subsection{INTRODUCTION}

The National Energy Conservation Policy Act, signed by the President on November 9, 1978, directs the Secretary of the Department of Energy (DOE) to set targets for increased utilization of energy-saving recovered materials for certain industries. These industries are: metals and metal products, paper and allied products, textile mill products, and rubber. These targets are to be established at levels representing the maximum feasible increase in the utilization of recovered materials that can be achieved progressively by January 1, 1987 and is consistent with technical and economic factors. DOE is also required to consider all actions that could be taken to increase each industry's utilization of energy-saving recovered materials. In addition, the Act requires that the Chief Executive Officer of eligible corporations (i.e., those consuming over a trillion Btu per year) in these industries include in their reports to DOE a statement of the volume of energy-saving recovered materials used, and their plans, if any, to increase the utilization of such materials.

\subsection{PURPOSE AND SCOPE}

Arthur D. Little, Inc. is under contract to DOE to assist in implementing the various provisions of the Act for the metals sector within the time period defined in the Act. The scope of Arthur D. Little's involvement emphasizes the following four major elements:

- data preparation and methodology development;

- analysis of the technological and economic factors in the metals industry in order to prepare draft targets for the use of recovered materials;

- technical support for public hearings to be held in the summer of 1979; and

- assistance in preparing the notice of final targets for Federal Register publication prior to November 9,1979

This report is the product of work done for the first two tasks enumerated above.

\subsection{APPROACH}

This study was carried out over a four-month period and relied principally on published information and inputs from various government and industry sources and industry trade associations listed below

- U.S. Department of Energy

- U.S. Bureau of Mines

- U.S. Department of Commerce

- U.S. Environmental Protection Agency

- National Association of Recycling Industries, Inc.

- Institute of Scrap Iron and Steel, Inc. 
- American Iron and Steel Institute

- Aluminum Recycling Association

- The Aluminum Association

- Copper Development Association

- Zinc Institute, Inc.

- Lead Industries Association, Inc.

- Brass and Bronze Ingot Institute

The following approach was used to arrive at draft targets for energy-saving recovered materials in each industry category.

- Wherever appropriate, the industry wàs subdivided for analytical convenience.

- Sources of recoverable materials were defined on the basis of data availability, whether they could replace any virgin material used by an industry subdivision, and whether such replacement was feasible betore $198 \%$.

- Technical constraints on the use of these recoverable materials were analyzed. Finally, the economic constraints on the availability of these recoverable materials were analyzed. Because of the voluntary nature of these targets, the level of utilization of recovered materials will primarily be determined by economics. Thus, a key feature of the approach is the use of econometric modeling techniques to estimate the targets for recovered materials for 1987. The modeling used 1976 as a base year. The technical/economic analysis considered such factors as capacity growth, impurity specifications, and other factors that would affect the demand for recoverable materials. On the supply side, the price responsiveness of the supply was evaluated in order to arrive at draft targets for these recoverable materials. The sensitivity of the targets to variations in key variables was also evalualed.

A benefit to be derived from the increased use of recoverable materials is in energy savings, as stated in the Act. Therefore, emphasis on different industries in the metals sector has been related to their energy consumption. The ferrrous industry (Iron and steel, ferrous fuundries dnd ferroalloys), as defined here, accounts for approximately $83 \%$ of the energy consumed in the metals sector (i.e., SIC 33), aluminum for about $11 \%$, copper for about $3 \%$, and all others for the remaining $3 \%$. Energy consumed in the lead and zinc segments is less than $1 \%$ each. Therefore, most of the effort in this study is focused on the ferrous scrap users, followed by the aluminum and copper industries.

\subsection{FINDINGS}

\subsubsection{General Discussion of Metals Recycling}

'The primary metals industries (i.e., those that supply metals mainly by extracting them from virgin raw materials or ores) and the secondary metals industries (i.e., those that mainly supply scrap and/or refined metals from scrap) differ from each other in many important respects, although their products are usually perfect substitutes for each other.

The primary industry relies on the exploitation of mineral deposits where a given metal is concentrated as a result of various types of geological activity. A mineral deposit is called an "ore' only if it can be exploited economically. That is, the difference between an ore deposit and a 
resource is that an ore deposit can be exploited economically under a given set of market conditions, whereas a resource has to wait for different market conditions before it can be exploited. Ore grade (the concentration of metal in the ore) and ore tonnage generally follow a lognormal distribution. Thus, the quantity of ore available for exploitation (ore reserves) will increase with rising prices. In the past, the richest deposits have been exploited first and, as the cost of extraction and processing decreased because of advances in technology, lower and lower grade deposits have been exploited. In this century, the reduction in the costs of extraction and processing through technological change has usually kept pace with ore grade degradation, so the real price of many metals has either remained constant or has declined somewhat. Many metallic ore deposits contain valuable byproducts such as gold, silver or molybdenum, which increase the economic value of the ore. Alternately, some ore deposits contain associated impurities, which require more complicated processing and decrease the value of the ore. Transportation costs are important in the primary metals industry; plants are usually located near the ore deposits in order to minimize transportation costs for raw materials or are in areas at nodes in existing transportation networks, or in areas that offer other benefits, such as low-cost energy.

The secondary metal industry is scrap-based and tends to locate near the source of its raw materials, which is typically near large urban centers. On an aggregate level, the raw materials used by the secondary industries can be classified into three groups: home scrap, prompt industrial scrap, and obsolete scrap. Home scrap, also referred to as runaround, is generated internally within a plant, usually because of downstream fabricating operations within the same plant or corporation. Home scrap, obviously compatible in composition, is remitted and used within the corporation. Prompt industrial scrap, also referred to as new scrap, generated as a result of manufacturing operations, is sold by the generator to a scrap dealer such as a scrap broker, a scrap collector, or a scrap reprocessor (which could include segments of the primary industry). Thus, home scrap and prompt industrial scrap are generated and used in identical fashion and are differentiated only by the absence or presence of a transaction. The quantity of home scrap generated in a particular industry reflects the technology of the industry, the presence or absence of vertical integration in the industry, and the geographical distribution of the plants belonging to a single corporation. Statistical data on home scrap generation and consumption are available for only a few industries; data on prompt industrial scrap are generally better. The two categories are not clear and distinct however. Essentially all the home and prompt industrial scrap is utilized directly. The supply of this scrap depends on the overall level of industrial activity in the manufacturing sector that generates the scrap, and it is quite price inelastic. Improvements in manufacturing technology have generally tended to reduce the availability of such scrap. Also, it is important to note that even more energy is saved when less home and prompt industrial scrap is generated than when this scrap is recycled.

The third category of scrap is obsolete scrap, recovered from materials that have reached the end of their useful life and/or have been discarded. This category of scrap is distinct from the other two categories in many ways. Because home and prompt industrial scrap are generated in specific locations and in predictable quantities, they have been reliable sources of scrap to the scrap dealers/collectors in the same fashion that ore deposits are a reliable source of raw materials to the primary industry. Obsolete scrap is also referred to as old scrap.

The generation of obsolete scrap, on the other hand, is usually very diffuse. It is often collected as a part of industrial or municipal waste collection operations. Whether this obsolete scrap is recycled or is lost to a landfill/wastc dump depends a great deal on the mode of collection 
(e.g., source segregation vs. a single collection of mixed wastes), the prevailing economic conditions in the scrap market, and the existing infrastructure for handling scrap. This infrastructure is composed of scrap collectors, scrap preprocessors, and upgraders, who can be distinct and separate from the people that melt the scrap. Because obsolete scrap is traded, it is often mixed with prompt industrial scrap at the preprocessing stage, and available statistics do not always distinguish between the two categories. The supply of obsolete scrap is somewhat more price elastic than for the other two categories. Besides source segregation, the technology for waste processing, transportation costs, and alternative disposal costs (e.g., landfill costs) are all important factors in obsolete scrap supply.

The primary metals industries are highly concentrated on the supply side, containing features of oligopolistic market structure (i.e., capacity and output are dominated by a small number of firms selling nearly identical products). In contrast, the secondary industries, by virtue of the large number of firms in the industry, resemble more closely the competitive model of economic theory.

Processing technology in the primary industry is usually more complex than in the secondary industry, and typically involves upgrading the ore, reducing it to metallic form, and refining the metal. The primary industry is much more capital-intensive per unit of output than the secondary industry because of high capital costs associated with extraction and with processing complexity. The equipment used in upgrading, reduction, and refining is specialized and can usually use only virgin raw materials, although some scrap can sometimes be substituted. Generally, equipment for melting, based on an external heat source, can substitute virgin and scrap materials freely; equipment based on internally-generated heat (pneumatic processes in the steel and cooper industries) requires a fixed amount of scrap for thermal balance.

The equipment used in the secondary industry is generally designed for the treatment of metallic materials and usually involves equipment for melting and for refining to remove impurities. This equipment cannot accept ores or concentrates since it is generally not capable of performing upgrading and reduction functions.

Both industries, and the secondary industry in particular, rely on the dilution of impurities in order to meet product specifications. The pedigree of prompt industrial and home scrap is easier to trace than that of obsolete scrap. Therefore the dilution technique can be used with the first two scrap sources in a predictable fashion. Of course, some impurities are valuable (gold and silver in copper scrap) and require refining techniques for their recovery.

In recent years, the economics of both primary and secondary industries have been affected by more stringent requirements for controlling in-plant emissions as well as emissions to the environment. Requirements for air pollution control are significant for most high-temperature operations. The emissions from the secondary industry tend to be complex because of the nature of the feedstock (expecially obsolete scrap). Furthermore, the small size of secondary plants and the batch nature of most secondary processes, lead to other problems not faced by the primary industry.

\subsubsection{ECONOMICS OF SCRAP RECYCLING}

Since the amount of new scrap generated is a function of technological factors in the metalproducing and metal-fabricating industries and is totally price inelastic in both the short and 
long run, the problem of recycling can best be addressed by considering the market for old scrap, which is the output of past production. During any given period, the market clears at some level of scrap delivery and price. This price-quantity combination will be determined primarily by the steepness of the supply and demand curves (i.e., their degree of price responsiveness or elasticity), by the length of the market period being considered, ("short-run" curves may well be different from "long-run" curves), and by exogenous factors such as levels of economic activity that move the two curves around.

The Demand Curve : Basically, the steepness of the demand curve for old scrap is set by the ease with which new ore or primary metal can be substituted for it in production at prevailing price levels. The greater the degree of substitution, the flatter the demand curve. This steepness is not immutable of course. It depends fundamentally on the mix of metal-using activities in the economy and the technical conditions of production that prevail at any given time. It is also likely that the short-run demand curve for scrap will be steeper than the long-run curve.

The Supply Curve: The scrap supply curve can also be thought of in terms of slope and position. Over longer periods, the price responsiveness of the old scrap supply is likely to be greater than in the short run. Just as in the case of the demand curve, the supply curve can also shift in response to changes in exogenous factors. Technical progress in the design of scrapping equipment will result in an outward shift of the supply curve as production of any quantity of scrap becomes less costly. On the other hand, increased prices for a number of factors (e.g., wages, implicit rental rates for capital) will cause an inward shift of the curve. Finally, the curve can shift around significantly in response to yearly fluctuations in scrapping as a result of variable investment rates in the distant past.

Market Dynamics: Obviously, the determination of price and output in the secondary scrap industry is a complex phenomenon, and no simple explanation for changes in the rate of recycling is possible. With sume significant degree of inelasticity of both supply and demand for scrap, however, one thing is clear: natural demand-side fluctuations from the present business cycle and supply-side fluctuations from past business cycles are themselves sufficient to guarantee substantial price instability in the scrap market. Furthermore, these major sources of instability are largely unpredictable to scrap suppliers, so a substantial element of risk is inescapable in the industry.

Scrap suppliers generally run small-scale operations and, in the absence of appropriate insurance or buffering mechanisms, must tend to be somewhat averse to risk.

Econometric Estimation: As noted earlier, a key feature of the approach used in this study is the use of econometric modeling for the estimation of the targets for recovered materials which address the question of how much more scrap will be forthcoming if scrap prices rise. The models used in this report, while limited by the availability of data resources and time, have been specified and estimated taking into account the "simultaneity" problem, the "identification" problem, and the statistical validity of the estimated parameters. 


\subsubsection{Ferrous Industry}

Industry Definition: The ferrous industry is defined as that collection of industries that consume iron and steel scrap. The major segments in this industry are:

- The iron and steel industry (SIC 3312,3315, 3316, and 3317). This segment includes fully integrated establishments engaged in manufacturing iron and steel from virgin sources as well as from scrap (including blast furnaces) as well as cold metal shops that rely on scrap and the fabricators of iron and steel into basic shaped by hot or cold rolling.

- Ferrous foundries (SIC 3321, 3322, 3324, and 3325). This segment includes establishments that produce gray iron, ductile iron, malleable iron, and steel castings.

- Ferroalloys (SIC 3313). 'This segment includes establishments engaged in ferroalloy manufacture by blast furnace, electro-metallurgical, or metallo-thermic processes.

Selection of Recoverable Materials: In each of the sectors, four general types of recoverable materials can potentially be consumed: ferrous scrap (home, prompt industrial, and obsolete); slags (from any smelting operation); dusts and sludges (generated from air pollution control or water pollution control operations); and mill scale (generated during fabrication operations). Of these, the principal marginal source of recoverable materials, whose utilization could increase in the near term, is obsolete scrap. Tables 4.2-9, 4.2-11, and 4.2-13

present data on the consumption of these recoverable materials by process units within each industry category.

The recycling of recovered materials can be constrained by the limitations of existing process equipment and/or by limitations imposed by the impurity content of the recoverable material. For sinter strands and blast furnaces, any limitations on the use of recovered material primarily derive from the impurity content, although there are also other process limilaliuns. The quantity of ferrous scrap the basic oxygen furnace (BOF) process is limited by the amount of energy available for melting. In current practice, a BOF can use nu mure than about $30 \%$ scrap without the addition of fuel energy to the furnace or to the scrap. Other processes do not have such a thermal process constraint but only constraints imposed by the impurity content of the recovered material.

Economic Considerations: In 1976, the ratio of ferrous scrap consumption to production of raw steel and castings (hot metal equivalent) was about $50 \%$. Whether this percentage can be raised by 1987 depends on the demand and supply dynamics of the ferrous scrap market. On the demand side, the amount of scrap that can be utilized is constrained by such technical factors as the split in steelmaking capacity between BOF's, open hearths, and eleclric furnaces. The supply consists of new scrap generuted by current industrial activity and old scrap extracted from discarded steel-containing products. New scrap generation is a function of technolugical factors and should be totally price-inelastic in both the short and long run. The supply of old scrap, however, would be price-elastic.

We have prepared an eclectic econometric model of the ferrous scrap market incorporating both engineering and economic parameters in an attempt depict realistically the technological and microeconomic factors that characterize the dynamics of demand and supply. This model 
incorporates information on the process characteristics of scrap-using and scrap-generating activities, the inventory of obsolete iron and steel, and the price elasticity of obsolete scrap supply, in order to generate draft targets that are both technically feasible and economically achievable.

Any draft target for the ferrous industry is affected by a number of factors, such as the growth rate of the industry to 1987 , the mix of steelmaking processes in 1987, scrap demand coefficients for the basic oxygen furnace and foundries, availability of scrap substitutes, and scrap exports. Because of this complexity, seven different scenarios were tested in the Arthur D. Little model. The results of these seven scenarios are shown in Table 4.2-24 reproduced here for convenience. Case I, the base case, is considered the most likely; the other cases are considered plausible. Cases II, III, and V are based on variations in the mix of steelmaking furnaces. Cases IV and VI presume a higher foundry scrap charge coefficient; and Case VII projects a lower overall annual growth rate for the iron and steel sector. In order to minimize the number of scenarios, the percentage of continuous cast steel has been fixed at $25 \%$ of total steel production for all cases. It is important to note that scrap exports are a major factor; the estimated draft target could change significantly if the level of scrap exports were to change because of structural changes in the international iron and steel industry. Table 1.4-1 presented on page 1-9 shows the 1987 base case targets for the ferrous and other industries.

\subsubsection{Aluminum Industry}

Industry Definition: The aluminum industry includes the following segments.

- Primary aluminum (SIC 3334) - establishments that produce aluminum from alumina.

- Secondary smelting and refining (SIC 3341 - aluminum-related sector only) establishments involved in the production of aluminum and aluminum-based alloys from scrap or dross.

- Aluminum foundries (SIC 3361) - establishments primarily engaged in manufacturing castings of aluminum and aluminum-based alloys.

- All others (SIC 3353, 3354, 3355, 3357, 3361, 3399, and 3463).

Many of these establishments are primarily engaged in fabrication of aluminum and generally send the scrap generated during fabrication to the other segments. However, some fabricators with melting facilities are also able to use aluminum scrap.

Selection of Recoverable Materials: Several types of recoverable materials can potentially be used. These include scrap (home, prompt industrial, and obsolete - with several subcategories based on chemical composition); low-grade drosses, skimmings and residues; and other solid wastes that contain metallics or that could be new non-bauxite sources of alumina. Of these, the principal marginal source of recoverable material is old scrap, whose availability could increase between now and 1987. The three major categories of old scrap where an increase is possible are: aluminum recovered via source segregation of beverage cans and other aluminum items; aluminum recovered from municipal solid wastes in resource recovery systems; and mixed scrap recovered from automobile shredding. Table 3.3-8 presents the available data on the consumption of these materials by the different sectors within the aluminum industry. 
TABLE 4.2-24.

RECYCLING RATIOS FOR FERROUS INDUSTRY FOR SEVEN SCENARIOS - 1987

Scenario

$19 \% 5=$

$1976=$

$1987=$

Case 1: Base case

Case I1: Base case except

- Production by open hearth furnaces equals $10 \%$ total raw steel production.

Case III: Base case except

- Growth in raw stccl production split 2:1 between basic oxygen and electric arc shops.

Case IV: Base case except

- Scrap demand coefficlent for foundries equals 1,3 ton/ton shipments.

Case V: Base case except

- Growtn in raw steel production split 2:1 between basic oxygen and electric arc shops.

- Production by open hearth furnaces equals $10 \%$ total raw steel production.

Case VI: Base case except

- Growth in raw steel production split $2: 1$ between basic oxygen and electric arc shops.

- Scrap demand coefficient for foundries equals 1.3 ton/ton shipments.

Case VII: Base case except

- Growth rate for finished steel production eyudls $1.6 \%$ per annum.
Target Expressed As Ratio of:

\begin{tabular}{|c|c|c|c|c|c|c|c|}
\hline $\begin{array}{l}\text { Total } \\
\text { Scrap } \\
\text { Consumed }\end{array}$ & $\begin{array}{l}\text { Purchased } \\
\text { Scrap } \\
\text { Consumed }\end{array}$ & $\begin{array}{l}\text { Obsolete } \\
\text { Scrap } \\
\text { Consumed }\end{array}$ & $\begin{array}{l}\text { Total } \\
\text { Scrap } \\
\text { Consumed }\end{array}$ & $\begin{array}{l}\text { Purchased } \\
\text { Scrap } \\
\text { Consumed }\end{array}$ & $\begin{array}{l}\text { Obsolete } \\
\text { Scrap } \\
\text { Consumed }\end{array}$ & $\begin{array}{l}\text { Total } \\
\text { Scrap } \\
\text { Consumed }\end{array}$ & $\begin{array}{l}\text { Purchased } \\
\text { Scrap } \\
\text { Consumed }\end{array}$ \\
\hline
\end{tabular}

to

to

Pig I ron and Scrap Charged ${ }^{3}$

$\begin{array}{lll}0.507 & 0.224 & 0.115 \\ 0.509 & 0.226 & 0.117\end{array}$

Raw Metal Equivalent 4

to

\begin{tabular}{|c|c|c|c|c|c|}
\hline 0.591 & 0.261 & 0.134 & 0.866 & 0.382 & 0.196 \\
\hline 58 & $0.26 !$ & 0.135 & 0.847 & 0.376 & 0.194 \\
\hline
\end{tabular}

0.536

0.264

0.137

0.597

0.294

0.153

0.839

0.413

0.214

0.538

0.266

0.139

0.600

0.297

0.156

0.843

0.418

0.219

0.520

0.249

0.122

0.581

0.278

0.136

0.816

0.390

0.191

0.539

0.269

0.143

0.605

0.302

0.160

0.849

0.424

0.225

0.522

0.251

0.124

0.584

0.281

0.139

0.820

0.394

0.195

0.524

0.254

0.128

0.588

0.285

0.144

0.826

0.400

0.202

0.533

0.261

0.135

0.593

0.291

0.150

0.834

0.409

0.211

1. Includes home, prompt industrial and obsolete scrap.

2. Includes prompt industrial and obsolete scrap.

3. Charged to steelmaking furnaces, ferrous foundries and ferroalloy plants.

4. Raw steel plus hot metal equivalent in the ferrous foundries.

5. Finished steel plus ferrous casting shipments. 
TABLE $\quad 1.4-1$

RECOVERED MATERIAL TARGETS FOR 1987

Industry Segment

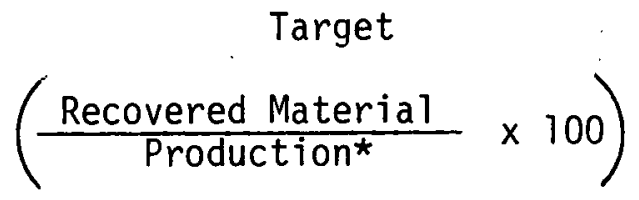

Ferrous

Aluminum

Copper

Zinc

Lead

* Domestic shipments or primary and secondary production.
$41.3 \%$

$34.7 \%$

$50.4 \%$

$36.0 \%$

$60.0 \%$ 
TABLE 3.3-8

\section{CONSUMPTION OF ALUMINUM SCRAP BY TYPE - 1976*}

$(1,000 \text { short tons })^{\star \star}$

Type of Scrap

New Scrap

Solids and Clippings

Borings and Turnings

Foil

Dross and Skimmings

Other

Total New Scrap

01d Scrap

Castings, Sheet and

Clippings

Aluminum Cans

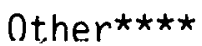

Subtotal

Sweated Pig

Total 01d Scrap

TUTAL
Secondary

Smelters
Primary Producers

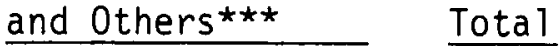

231

136

1

126

24

518

121

35

101

17

153

170

707

159

82

759

537

\begin{tabular}{l}
$17 \quad 99$ \\
\hline 22
\end{tabular}

581

152

7

230

85

1,055

$\begin{array}{rr}350 & 581 \\ 16 & 152 \\ 6 & 7 \\ 104 & 230 \\ 61 & 85 \\ 537 & 1,055\end{array}$

$\begin{array}{rr}350 & 581 \\ 16 & 152 \\ 6 & 7 \\ 104 & 230 \\ 61 & 85 \\ 537 & 1,055\end{array}$

156

109

*Includes imported scrap. The reporting companies reported that $6.62 \%$ of total receipts of aluminum-based scrap or 97,800 short tons was received on toll arrangements.

$\star \star$ Rounded to the nearest thousand.

$\star \star \star 0$ thers include foundries, fabricators, and chemical plants.

$\star \star \star \star$ Includes data on aluminum-copper radiators.

Source: Aluminum, Preprint from ilinerals Yearbook, 1976. 
In general, recycling can be constrained by limitations of existing process equipment and by limitations imposed by the impurity content of the recoverable materials. All industry subdivisions utilize melting furnaces and there is no process constraint concerning the amount of scrap that can be melted in the furnaces. However, the furnaces used by some segments of the industry are better suited for melting given types of scrap than others. The principal refining step in the recycling of aluminum-based scrap is the removal of magnesium by treating the molten metal with chlorine or aluminum fluoride. Any other impurities in the metal are usually controlled by dilution of the charge with pure metal. Stainless steel and zinc are considered the major metallic impurities, while nonmetallic contaminants such as paint, oil, plastic, insulation, and rubber have a nuisance value because they are a major source of air pollution.

Economic Considerations: Table 4.3-5 shows the balance of sources and uses for purchased aluminum scrap for 1976. In that year, old scrap accounted for about $11 \%$ of supply. Whether the amount of old scrap consumed can be raised by 1987 depends on the supply and demand dynamics of the aluminum market. On the demand side, technology imposes no relevant physical constraint. The economic aspects of scrap demand relate to the price of scrap in relation to the price of virgin aluminum.

A simple model has been designed to predict the volume of aluminum scrap that will be generated under a variety of scenarios. This volume is then used to calculate the draft target. The model contains five equations that predict the supply of scrap from new scrap, obsolete scrap from cans, as well as the withdrawal rate for other old scrap from the inventory of aluminum available for scrapping. This inventory is adjusted to exclude the contribution by the increasing aluminum content of cars and Class I trucks. U.S. scrap consumption is calculated by adding scrap supply as predicted and subtracting exogenous scrap exports. These data are then used to calculate the draft targets.

The draft targets are directly affected by the maximum withdrawal rate for old scrap and by variations in new scrap generation, scrap reclamation from cans, scrap recovery from municipal solid waste, growth rate in aluminum consumption, and the level of imports. Table 4.3-10 presents the recycling targets for 1987, where the targets are expressed as different ratios to domestic primary plus domestic secondary production. Case I, the base case, is considered the most likely; the other cases are considered plausible. Case II is identical to the base case except that the real price of scrap is higher. In Case III, exports are assumed to drop to zero to simulate a policy of restricting scrap exports. In Case IV, new scrap generation rate is assumed to be lower, consistent with predicted improvement in fabrication yields. The base case target is also shown in Table 1.4-1.

\subsubsection{Copper Industry}

Industry Definition: The copper industry is defined as that group of industries that consume copper-bearing scrap. The major segments in this industry are:

- Primary copper industry (SIC 3331) - This segment includes establishments engaged in producing copper from virgin ore sources.

- Secondary copper industry (SIC 33412) - This segment includes establishments engaged in recovering copper from copper and copper-based scrap. 
TABLE 4.3-5

1976 MATERIAL BALANCE FOR ALUMINUM SCRAP

(Militions of Pounds)

Sources

\begin{tabular}{|c|c|}
\hline $\begin{array}{l}\text { Purchased Scrap } \\
\text { New Scrapl }\end{array}$ & 2,490 \\
\hline O1d Scrap & \\
\hline Aluminum Cans & 217 \\
\hline Other 01d Scrap 1,2 & 946 \\
\hline Purchased Scrap & 3,653 \\
\hline Home Scrap ${ }^{3}$ & 6,675 \\
\hline Total & 10,328 \\
\hline
\end{tabular}

Uses
U.S. Consumption of Purchased Scrap 3,482

U.S. Consumption of Home Scrap $3 \quad 6,675$

Exports $^{2}$

171

Source: Arthur D. Little, Inc. estimates derived from:

1 Aluminum, Preprint 1976 Minerals Yearbook.

2 Aluminum Statistical Review, 1976.

3 Communication, The Aluminum Association, May 8, 1979. 
TABLE $4.3-10$

RECYCLING RATIOS FOR ALUMINUM INDUSTRY

FOR FOUR SCENARIOS - 1987

Scenario

$1976=$

$1987=$

Case I

Base Case

Case II

Base Case except

Price of scrap $=13.1 \% / 1 \mathrm{~b}$

$W D=0.00461$

Case III

Base Case except

Exports $=0$

Case IV

Base Case except New Scrap Generation

Coefficient $=0.19$
Target Expressed as Ratio of

\begin{tabular}{cccc}
\hline 0ld Scrap & 0ld Scrap & Total Scrap & Total Scrap \\
Consumption & Metallic Recovery & Consumption & Metallic Recovery
\end{tabular}
to

Domestic Primary Production Plus Secondary Metallic Production

0.100

0.0845

0.319

0.269

0.118

0.100

0.347

0.293

0.146

0.123

0.373

0.315

0.129

0.109

0.357

0.302

0.118

0.100

0.333

0.281 
- Fabricators (SIC 3351) - This segment includes establishments engaged in rolling, drawing and extruding copper in copper-based alloys.

- Foundries (SIC 3362) - This segment includes establishments engaged in casting of copper-based alloys.

Selection of Recoverable Materials: The materials available for recycling cover a range of scraps varying from No. 1 wire, which is essentially pure copper, to low-grade scrap, and include a wide variety of unalloyed and alloyed copper scrap grades. A somewhat special category is the utilization of mine waste by leaching for extraction of additional copper; copper produced in this fashion is normally considered primary copper. Table 4.4-3 shows available data on the consumption of these recoverable materials in each industry subcategory.

The secondary industry relies primarily on scrap, and its different segments purchase and handle the entire range of high- and low-grade alloyed and unalloyed scrap as well as residues. 'I'hus, there are no constraints other than those imposed by the impurity content of the scrap. The scrap-handling ability of the primary smelters is limited. Although smelting furnaces can, in principle, accept scrap, they are actually designed to accept only finely powdered materials. Lowgrade scrap can be added to the converter, and higher-grade scrap is acceptable in any amount at the cathode melting stage. Brass mills and foundries do not have process constraints, but only technical constraints based on the composition of the recoverable materials.

Economic Considerations: As with other metals, obsolete copper scrap is the principal source of incremental recoverable material. In the past, obsolete scrap has played an important role in meeting fluctuating levels of excess demand as indicated in Table 4.4-5. Table 4.4-10 shows that the recycling ratio (defined as copper from recovered materials divided by copper from recovered material plus primary copper production) has been relatively stable between 1970 and 1976. 'I'he econometric results given in the literature, price and output projections that incorporate the anticipated impact of pollution abatement legislation during the coming decade, and the size of the recoverable copper reservoir have been used to calculate the draft target that appears technically and economically teasible. 'T'able 4.4-9 shows the draft target for 1987.

\subsubsection{Zinc Industry}

Industry Definition: The zinc industry is defined here as:

- Establishments engaged in primary smelting and refining of zinc (SIC 3333)

- Establishments engaged in smelting zinc from scrap materials (SIC 33414)

- Zinc Foundries (SIC 33691).

Selection of Recoverable Materials: The zinc industry recovers zinc (and zinc oxide) from a broad spectrum of home, prompt industrial, and obsolete scrap. Zinc can also be recovered from steelmaking dusts, although this process is not practiced on any significant scale in this country. As with other metals, obsolete scrap represents a principal marginal source of recoverable material. Table 4.5-3 presents data on consumption of different grades of recoverable material within each industry subcategory.

Different types of processes are used by different segments of the zinc industry and each process has certain constraints. For example, oxidized zinc materials are acceptable to vertical 
TABLE 4.4-3

CONSUMPT ION OF RECOVERABLE MATERIALS 1976 - COPPER INDUSTRY'

(Gross Weight in Tons)

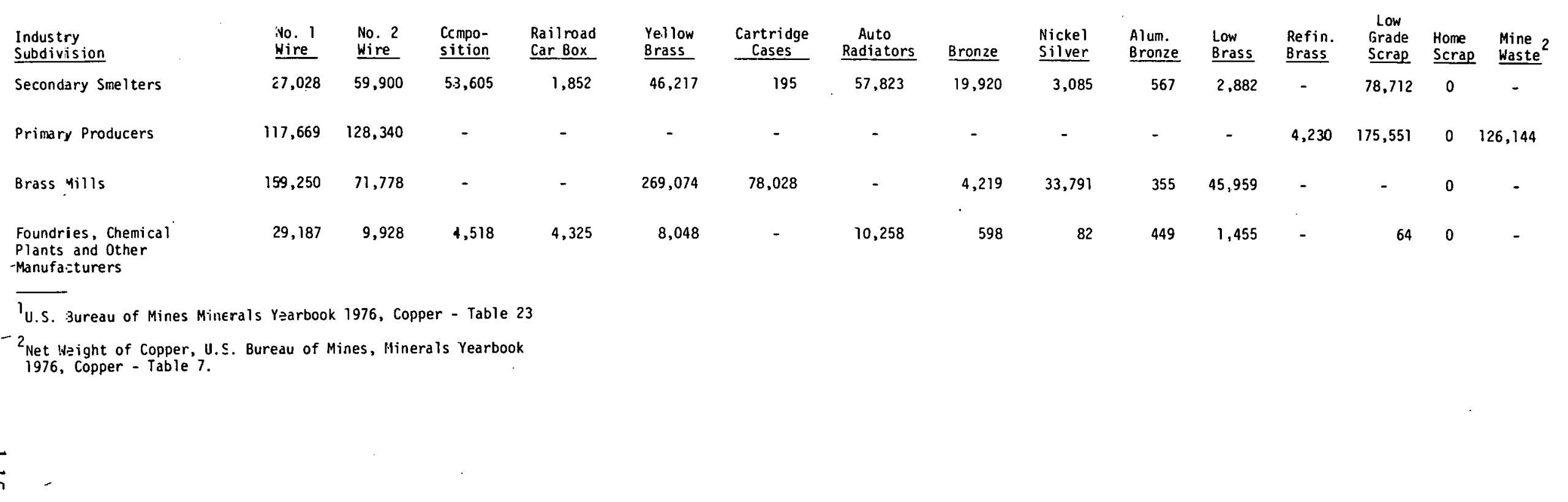


TABLE $4.4-10$

COPPER RECYCLING RATIOS, 1970-1976*

$\begin{array}{ll}\text { Year } & \frac{\text { Ratio }}{1970} \\ 1971 & 45.6 \% \\ 1972 & 48.5 \% \\ 1973 & 46.4 \% \\ 1974 & 47.4 \% \\ 1975 & 49.4 \% \\ 1976 & 44.8 \% \\ & 46.9 \%\end{array}$

Mean Ratio: $47.0 \%$

* Ratios derived from Table 4.4-7. 
TABLE 4.4-9

RECOVERED MATERIAL TARGET FOR COPPER INDUSTRY (1987)

$\frac{\text { Recovered Material* }}{\text { Domestic Primary \& Secondary Production }} \times 100=50.4 \%$

* Prompt industrial and old scrap, plus precipitate copper from mine waste. 
TABLE $4.5-3$

CONSUMFTION OF RECOVERABLE KATERIALS - 1976

ZINC INDUSTRY

Types of Recovered Materials in Tons of Zinc Contained

Process

Galvanizers' New Die Chemical Home ald Die Cast General

Residues

Cast Sorap Residues

Scrap

Scrap

Scrap Total

Electrolytic

Reduction

NA

NA

$\stackrel{\dot{\omega}}{\infty}$ Vertical Distillation
Reports

$31,5 \mathrm{CO}$

10,500

NA

43,000

Secondary Distillers

$55,3 \mathrm{CO}$

7,900

1,500

NA

53,300

10,800

129,300

Foundries

NA

2,200

2,200

Chemical and Pigment

plants

8,300

22,700

NA

0

37,000

NA: Data not available.

Source: Estimates tased on unpublished Tables 13, 14, 15 for Zinc to be in the 1976 Mineral Yearbook, Volume i, Ne:als, Minerals and Fuels, U.S. Department of the Interior, Bureau of Fines. 
distillation retorts and to chemical and pigment plants. The foundries recover zinc from scrap that has a high metallic content and controlled impurities. The secondary distillers process all zinc scrap but can recover only metallic zinc in the scrap. The primary electrolytic reduction plants do not consume any recoverable material. The major constraints from the viewpoint of product quality are in the foundries and in other applications such as galvanizing and zinc oxide products.

Economic Considerations: Economic considerations were not evaluated for the zinc industry, but are incorporated in the assumptions used in this analysis. Increased recovery of zinc will center on old scrap, particularly old die castings recovered from automobiles. Table 4.5-4 shows the estimated target for 1987 . This target, equivalent to $36 \%$ of the domestic zinc smelted by 1987 , is sensitive to galvanizer zinc consumption, the rate of increase in automobile shredders where nonferrous fractions are separated, and any increase in recovery of flue dust chemical residues and changes in domestic production rates.

\subsubsection{Lead Industry}

Industry Definition: The lead industry is defined in this report as:

- Establishments engaged in the primary smelting and refining of lead (SIC 3332)

- Establishments engaged in the secondary smelting and refining of lead (SIC 3341)

Selection of Recoverable. Materials: The recoverable materials fall broadly into four groups - namely, new scrap, old scrap, slags and dusts. Table 4.6-2 presents available data on the consumption of these materials in the lead industry.

Theoretically, there is no technical limit to the amount of recoverable material that can be recycled. 'I'here are, however, constraints dictated by the composition of the recoverable materials. For example, high-antimony lead batteries are normally recycled back into the same product. Similarly, blast furnaces cannot accept a large quantity of dust without agglomeration.

Economic Considerations: Economic factors were not directly evaluated in this industry analysis, but they are incorporated in the assumptions used. Table 4.6-5 shows the draft target for the lead industry (defined as the recycling ratio; that is, the ratio of secondary production to primary plus secondary production) for 1987 . The two most critical assumptions are that primary lead production will remain at 700,000 short tons annually, and that the ultimate recovery rate for scrap batteries is 0.75 . The other variables have relatively little effect on the target.

\subsection{IMPACT OF GOVERNMENT ACTIONS ON RECYCLING}

Many government policies can potentially have an impact on the degree of recycling in all types of primary and secondary metals industries. Analyses of the impact of policy changes in these areas was outside the scope of the present study. The significant areas are:

- Tax Policy

- Freight Rates

- Product Specifications

- Residuals (Pollution Control)

- Market Structure

- Export Controls on Scrap 
TABLE $4.5-4$

RECOVERED MATERIAL TARGET FOR ZINC INDUSTRY (1987)

Recovered Material*

Domestic Primary \& Secondary Production

$$
x 100=36 \%
$$

* Purchased scrap, i.e., prompt industrial and obsolete scrap. 
TABLE $4.6-2$

SERAP CONSUMPTION IN THE LEAD INDUSTRY (1970-1976)

(Gross Tons)

\begin{tabular}{|c|c|c|c|c|c|c|c|}
\hline & 1970 & 1971 & 1972 & 1973 & 1974 & 1975 & 1976 \\
\hline $\begin{array}{l}\text { New Scrap: } \\
\text { Drosses \& Residues }\end{array}$ & 121,766 & 143,382 & 158,881 & 154,682 & 129,400 & 136,066 & 141,923 \\
\hline Home Scrap & NA & NA & NA & NA & NA & NA & NA \\
\hline $\begin{array}{l}\text { Old Scrap: } \\
\text { Battery Plates }\end{array}$ & 512,030 & 486,792 & 509,858 & 544,438 & 614,364 & 623,448 & 589,797 \\
\hline Cable Lead & 26,544 & 29,455 & 26,775 & 26,397 & 45,507 & 50,569 & 47,738 \\
\hline Soft Lead & 52,426 & 48,925 & 46,668 & 36,279 & 33,641 & 32,642 & 29,172 \\
\hline Hard Lead & 19,015 & 27,254 & 27,641 & 51,992 & 54,778 & 26,912 & 30,395 \\
\hline Type Metal & 32,001 & 25,813 & 23,690 & 27,950 & 25,745 & 19,820 & 14,292 \\
\hline Mixed Common Babbitt* & 11,799 & 11,665 & 11,049 & 13,534 & 12,025 & 8,552 & 7,839 \\
\hline Solders \& Tinny Lead & 10,640 & 11,464 & 9,815 & 11,991 & 13,663 & 11,250 & 3,517 \\
\hline $\begin{array}{l}\text { Slag : } \\
\quad \text { Secondary Reverberatory }\end{array}$ & --- & $-5-5$ & $--\cdots$ & -- & -- & $-\cdots$ & $-\cdots-$ \\
\hline $\begin{array}{l}\text { Dust : } \\
\quad \text { Primary Blast Furnace }\end{array}$ & --- & --- & --- & - & -- & --- & $-\cdots-$ \\
\hline Secondary Blast Furnace & --- & --- & -- & - & -- & --- & ---- \\
\hline Secondary Reverberatory & --- & -- & --- & - & -- & -- & $-\cdots$ \\
\hline
\end{tabular}

*includes corisumption at foundries

NA: Not avajlable.

Source: U.S. Bureau of Mines Minerals Yearbook, 1976.

Arthur D. Little, Inc. 
TABLE 4.6-5

RECOVERED MATERIAL TARGET FOR LEAD INDUSTRY (1987)

Recovered Material*

Domestic Primary \& Secondary Production

$\times 100=60 \%$

* Purchased scrap, i.e., prompt induslrial and obsolete scrap. 


\subsection{INTRODUCTION}

This chapter provides an introductory discussion of the factors that affect the recovery and reuse of secondary materials and the competition between the primary and secondary metals industries.

Section 2.1 discusses these industries in terms of resource characteristics, industry technology, pollution control requirements, market structure, the economics of recycling, and the issues involved in econometrically estimating scrap supply response behavior.

Section 2.2 presents the methodology established by the Department of Energy (DOE) for the metals, textiles, rubber, and pulp and paper industries, which was adapted to this study.

Section 2.3 notes the areas in which government policies might have a significant impact on the utilization of primary and secondary metals and, therefore, on any recycling targets between now and 1987.

\subsection{GENERAL DISCUSSION OF METALS RECYCLING}

The primary metals industries (i.e., those that supply metals mainly by extracting them from virgin raw materials or ores) and the secondary metals industries (i.e., those that mainly supply scrap and/or refined metals from scrap) differ from each other in many important respects. Although their products are usually perfect substitutes for each other, the two industries differ in terms of sources of feedstocks and feedstock availability, supply response, market structure, growth rates over the historical period, and, in some cases, somewhat specialized enduse applications, in spite of the non-differentiated nature of their products. The discussion below examines the differences between the two industries and the way in which such differences might affect the selection of economically feasible targets for increasing the use of energy-saving recovered materials.

\subsubsection{Resource Characteristics}

The primary industry relies on the exploitation of mineral deposits where a given metal is concentrated as a result of various types of geological activity. A mineral deposit is called an "ore" only if it can be exploited economically. That is, the difference between an ore deposit and a resource is that an ore deposit can be exploited economically under a given set of market conditions, whereas a resource has to wait for different market conditions before it can be exploited. Ore grade (the concentration of metal in the ore) and ore tonnage generally follow a lognormal distribution. Thus, the quantity of ore available for exploitation (ore reserves) will increase with rising prices. In an operating mine, prevailing economic conditions define the "cutoff" grade for a given deposit. Any operating mine always contains rock that is below the cut-off grade, which is removed and dumped in surface mining or is left in place in underground mining. (Thus, in general mine waste in surface mining does not meet prevailing economic criteria for extraction and is not an economic source of energy-saving recovered material at the time of mining for primary metal recovery.)

Thus, any portion of the deposit above the cut-off grade may be exploited economically, while those portions of the deposit below the cut-off grade are treated as sub-marginal and are not 
extracted. In the past, the richest deposits have been exploited first and, as the cost of extraction and processing decreased because of advances in technology, lower and lower grade deposits have been exploited. In this century, the reduction in the cost of extraction and processing through technological change has usually kept pace with ore grade degradation, so the real price of many metals has either remained constant or has declined somewhat. As economic conditions (prices) change, the cut-off grade is increased or decreased, with an equivalent change in total economic reserves. That is, supply response is conditioned by the prevailing as well as the expected metal price. At the present time, the cut-off ore grades in the major metals industries are: at least $30 \%$ iron $\mathrm{fc}$ : magnetite ores and up to $65 \%$ iron for direct shipping ores; $30 \%$ alumina for bauxite; $0.4 \%$ copper for sulfide ores; and 2-3\% metal for lead and zinc ores. Many metallic ore deposits contain valuable byproducts such as gold, silver or molybdenum, which increase the economic value of the ore. Alternately, some ore deposits contain associated impurities, which require more complicated processing and decrease the value of the ore. Transportation costs are important in the primary metals industry; plants are usually located near the ore deposits in order to minimize transportation costs for raw materials or at nodes in existing transportation networks, or in areas that offer other benefits, such as low-cost energy.

The secondary metal industry is scrap-based and tends to locate near the source of its raw materials, which is typically near large urban centers. On an aggregate level, the raw materials used by the secondary industries can be classified into three groups: home scrap, prompt industrial scrap, and obsolete scrap.

Home scrap is generated internally within a plant, usually because of downstream fabricating operations within the same plant or corporation. Home scrap is also referred to as runaround scrap. Home scrap, obviously compatible in composition, is remelted and used within the corporation.

Prompt industrial scrap, generated as a result of manufacturing operations, is sold by the generator to a scrap dealer such as a scrap broker, a scrap collector, or a scrap reprocessor (which could include segments of the primary industry). Prompt industrial scrap is also referred to as new scrap. Home scrap and prompt industrlal scrap are generaled and used in identical fashlivin and are differentiated only by the absence or presence of a transaction. The quantity of prompt and home scrap generated in a particular industry reflects the technology of the industry, the presence or absence of vertical integration in the industry, and the geographical distribution of the plants belonging to a single corporation. Statistical data on home scrap generation and consumption are available for only a few industries; data on prompt industrial scrap are generally better. The two categories are not clear and distinct however. Essentially all the home and prompt industrial scrap is utilized directly. The supply of this scrap depends on the overall level of industrial activity in the manufacturing sector that generates the scrap, and it is quite price inelastic. Improvements in manufacturing technology have generally tended to reduce the availability of such scrap. Also, this reduction in home and prompt scrap generation contributes more towards energy saving than scrap recycle.

Obsolete scrap is recovered from materials that have reached the end of their useful life and/or have been discarded. It is also referred as old scrap or post-consumer scrap. 'This category of scrap is distinct from the other two categories in many ways. Because home and prompt industrial scrap are generated in specific locations and in predictable quality and quantities, they have been reliable sources of scrap to the scrap dealers/collectors in the same fashion that ore deposits are a reliable source of raw materials to the primary industry. 
The generation of obsolete scrap, on the other hand, is usually very diffuse. It is often collected as a part of industrial or municipal waste collection operations. Whether this obsolete scrap is recycled or is lost to a landfill/waste dump depends a great deal on the mode of collection (e.g., source segregation vs. a single collection of mixed wastes), the prevailing economic conditions in the scrap market, and the existing infrastructure for handling scrap. This infrastructure is composed of scrap collectors, scrap preprocessors, and upgraders, who can be distinct and separate from the people that melt the scrap. Because obsolete scrap is traded, it is often mixed with prompt industrial scrap at the preprocessing stage, and available statistics do not always disiinguish between the two categories. The supply of obsolete scrap is somewhat more price elastic than for the other two categories. Besides source segregation, the technology for waste processing, transportation costs, and alternative disposal costs (e.g., landfill costs) are all important factors in obsolete scrap supply. It is important to note that if products are exported, the obsolete scrap will be generated in the country that purchased the product and not the country that manufactured them.

\subsubsection{Industry Technology}

Processing technology in the primary industry is usually more complex than in the secondary industry, and typically involves upgrading the ore, reducing it to metallic form, and refining the metal. The primary industry is much more capital-intensive per unit of output than the secondary industry because of high capital costs associated with extraction and with processing complexity. The equipment used in upgrading, reduction, and refining is specialized and can usually use only virgin raw materials, although some scrap can sometimes be substituted. Generally, equipment for melting, based on an external heat source, can substitute virgin and scrap materials freely; equipment based on internally-generated heat (pneumatic processes in the steel and copper industries) requires a fixed amount of scrap for thermal balance.

The equipment used in the secondary industry is generally designed for the treatment of metallic materials and usually involves equipment for melting and for refining to remove impurities. This equipment cannot accept ores or concentrates since it is generally not capable of performing upgrading and reduction functions.

Both industries, but the secondary industry in particular, rely on the dilution of impurities in order to meet product specifications. The pedigree of prompt industrial and home scrap is easier to trace than that of obsolete scrap. Therefore, the dilution technique can be used with the first two scrap sources in a predictable fashion. Of course, some impurities are valuable (gold and silver in copper scrap) and require refining techniques for their recovery.

\subsubsection{Pollution Control}

In recent years, the economics of both primary and secondary industries have been affected by more stringent requirements for controlling in-plant emissions as well as emissions to the environment. In the primary industries, solid waste generation is heaviest at the mining and concentration stage, while air and water pollution control requirements affect the different segments to varying degrees. Requirements for air pollution control are significant for most hightemperature operations. 
The emissions from the secondary industry tend to be complex because of the nature of the feedstock (especially obsolete scrap). Furthermore, because of the small size of secondary plants and the batch nature of most secondary processes, the economic impact of pollution control requirements tends to be more severe on the secondary industry.

\subsubsection{Market Structure}

The primary metals industries are highly concentrated on the supply side, containing features of oligopolistic market structure (i.e., capacity and output are dominated by a small number of firms selling nearly identical products). In contrast, the secondary industries, by virtue of the large number of firms in the industry, resemble more closely the competitive model of economic theory.

A recent study has shown that market structure of these industries and the degree of competition does not have much bearing on the rate of recycling. ${ }^{(1)}$ In the nonferrous melals industries, the degree of recycling is determined primarly by:

- the structure of the end-use spectrum peculiar to each metal;

- the magnitude and average age of the in-service inventory of each metal;

- the price of both primary and secondary metal; and cyclical fluctuations in the level of economic activity.

The study concludes that positive actions designed to increase the rate of recycling will have to focus on the demand side (i.e., on the end-use spectrum) for each metal and that the rapidly rising cost of energy will provide a stimulus for increasing nonferrous metals scrap recovery.

\subsubsection{Economics of Scrap Recycling}

The supply of scrap consists of "new" scrap (home and prompt industrial) and "old" or obsolete scrap. The amount of new scrap generated is a function of technological factors in the metal-producing and metal-fabricating industries and is totally price inelastic in both the short and long run.

The problem of recycling, therefore, can best be addressed by considering the market for old scrap, which is the output of past production. (New scrap may be regarded as a byproduct of current production and cannot be said to have a market in any meaningful sense.) During any given period, the market clears at some level of scrap delivery and price. This price/quantity combination will be determined primarily by the steepness of the supply and demand curves (i.e., their degree of price responsiveness or elasticity), by the length of the market period being considered ("short-run" curves may well be different from "long-run" curves), and by exogenous factors such as the level of economic activity that move the two curves around.

\subsubsection{The Demand Curve}

Basically, the steepness of the demand curve for old scrap is set by the ease with which new ore or primary metal can be substituted for it in production at prevailing price levels. The greater the degree of substitution, the flatter the demand curve. (Intuitively, this means that a fairly small increase in the price of old scrap at a given ore price will result in a relatively large drop in the demand for old scrap as users substitute toward primary sources, and, conversely, as the old 
scrap price decreases.) This steepness is not immutable of course. It depends fundamentally on the mix of metal-using activities in the economy and the technical conditions of production that prevail at any given time.

It is also likely that the short-run demand curve for scrap will be steeper than the long-run curve. In the short run, industrial plants may be set for a particular rate of scrap input, and higher scrap prices will not have any immediate impact on the sales of scrap-using products. In the longer run, however, production processes can be adjusted to use less scrap (and more ore). At the same time, price-responsive market demand will shift in favor of products from relatively oreintensive as opposed to scrap-intensive processes. For both these reasons, long-run demand for scrap will be considerably more price-responsive than short-run demand.

While the steepness of the demand curve depends on substitutability in aggregate metals production as well as the length of the time period being considered, the position of the curve is affected by the price of new ore and the level of demand for metal products (which is itself a function of the generalized price of metal products). The higher the price of new ore, the more scrap will be demanded at any given scrap price. Similarly, the higher the demand for metal products, the higher the demand for scrap at any given price.

\subsubsection{The Supply Curve}

The scrap supply curve can also be thought of in terms of slope and position. Basically, the steepness of the curve in the short run will reflect the extra cost at which variable production inputs can be obtained. Short-run response may require the payment of overtime wages or multiple shifting of the available facilities, with a consequent increase in the rate of depreciation. Furthermore, the stock of "minable" refuse for scrap recovery is limited in any period, and diminishing returns are bound to apply (unit increases in supply will require ever-greater intensities of extraction effort, since the most readily available scrap will be utilized first).

Over longer periods, the price responsiveness of the old scrap supply is likely to be greater than in the short run. More labor can be hired at the going (non-overtime) wage, and old, relatively inefficient, scrapping equipment can be profitably pressed back into service. In addition, users of capital equipment will adjust their scrapping rates to the higher scrap value of their equipment so that a higher volume of scrap will be forthcoming.

Just as in the case of the demand curve, the supply curve can also shift in response to changes in exogenous factors. Technical progress in the design of scrapping equipment will result in an outward shift of the supply curve as production of any quantity of scrap becomes less costly. On the other hand, increased prices for a number of factors (e.g., wages, implicit rent rates for capital) will cause an inward shift of the curve. Finally, the curve can shift around significantly in response to yearly fluctuations in scrapping as a result of variable investment rates in the distant past.

\subsubsection{Market Dynamics}

Obviously, the determinatio: of price and output in the secondary scrap industry is a complex phenomenon, and no simple explanation for changes in the rate of recycling is possible. With some significant degree of inelasticity of both supply and demand for scrap, however, one thing is clear: natural demand-side fluctuations from the present business cycle and supply-side 
fluctuations from past business cycles are themselves sufficient to guarantee substantial price instability in the scrap market. Furthermore, these major sources of instability are largely unpredictable to scrap suppliers, so a substantial element of risk is inescapable in the industry. Scrap suppliers generally run small-scale operations and, in the absence of appropriate insurance or buffering mechanisms, must tend to be somewhat averse to risk. Thus, any factor that would reduce this price instability would tend to increase the equilibrium production level for scrap even if the average price remained unchanged.

\subsubsection{Econometric Estimates of Scrap Supply Elasticity}

\subsubsection{Introduction}

The scrap market plays an essential role in recycling, and it is important to know how much more scrap will be forthcoming if scrap prices rise. While econometric models of scrap metals markets are obviously useful in this context, they must be properly specified and estimated if they are to yield meaningful results. This discussion provides an introduction to the econometric. analysis of scrap supply.

\subsubsection{The Simultaneity Problem}

At any given time, the markets for scrap, ore, and metal products are observed to clear simultaneously at some set of prices and quantities. Since all of these quantities and prices are established interdependently, it is not possible to observe the behavior of one market in isolation from the others and draw any firm conclusions. In econometric parlance, this is known as "the simultaneity problem," and any attempt to estimate the parameters of an equation that describes one part of the system must take simultaneity into account.

In attempting to focus on the supply schedule for scrap, i.e., how the quantity of scrap supplied varies with price, it is not sufficient simply to observe the time paths of scrap price and quantity delivered and hope that this information will yield adequate information about price responsiveness. Demand-side variables will inevitably have intervened, as will exogenous forces that have shifted the supply schedule. Shifts in the price of metal products and ore may have shifted the demand curve, for example, while the introduction of new equipment or shifts in the costs of other inputs to scrap production (e.g., labor, capital) may well have acted on the supply side. Thus, the observed path of prices and delivered quantities in the scrap industry is the result of a simultaneous interaction of supply and demand schedules for scrap. This interaction might weli generate a time path of prices and quantities as shown in Figure 2-1.

It is along the supply curve in this figure that any demand-induced increase in price will have to trace out its consequences for the output of scrap. Although it is not immediately obvious how to deduce the shape of the supply curve from the record of price-quantity combinations generated by the interaction of supply and demand, econometricians have developed a series of methods for doing so. No econometric estimates of price responsiveness on the supply side can be taken seriously unless they have been generated by a technique which takes this problem of "simultaneity" into account.

\subsubsection{The Problem of Supply Equation Specification}

A second major problem in estimating price-responsiveness in the scrap industry is the identification of short-run and long-run behavior. While a sudden change in price may not have 


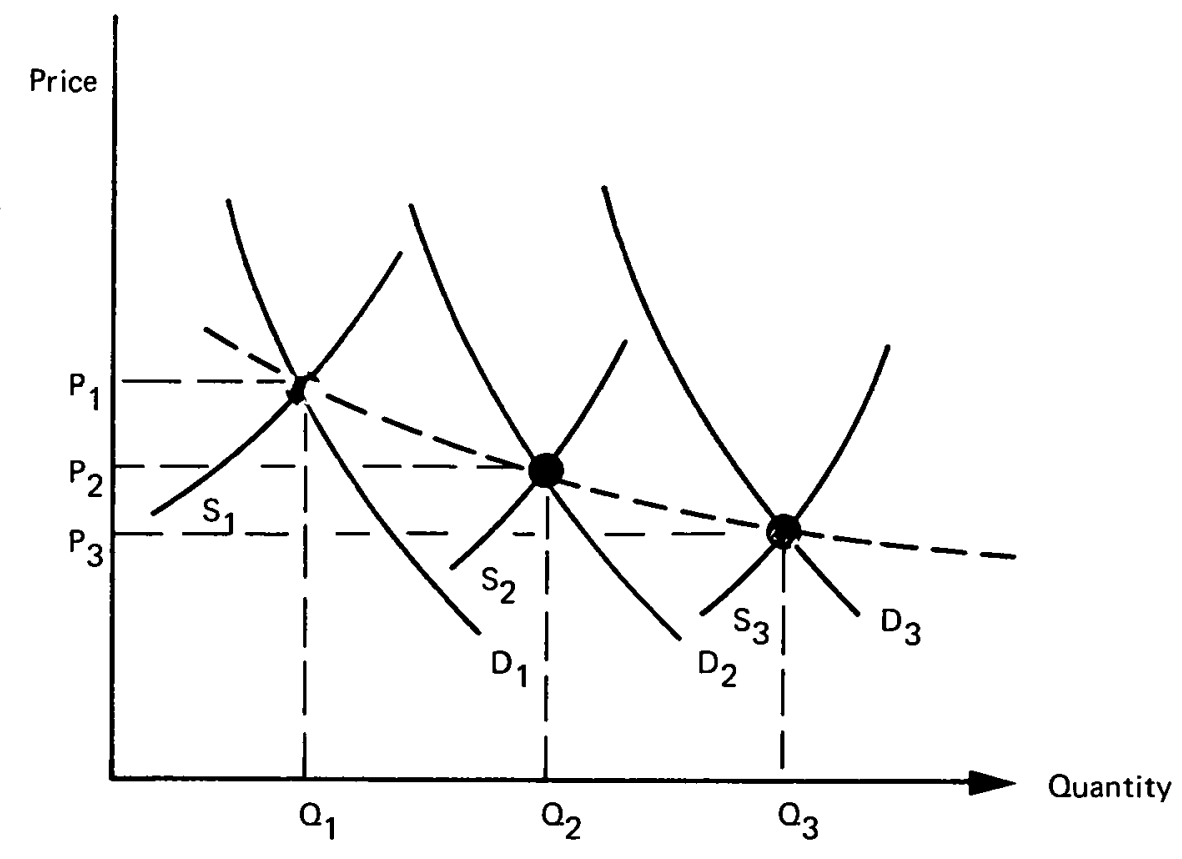

FIGURE 2-1 AN ILLUSTRATION OF THE SIMULTANEITY PROBLEM 
much immediate effect on supply, adjustments of factor inputs over a somewhat longer time period will often permit a significant response. It is therefore necessary to specify the scrap supply equation in such a way that the difference between short- and long-run responsiveness can be accounted for. The way in which this is generally done can be described with the aid of a brief example.

In modeling the price-responsiveness of scrap, the problem of simultaneity has been corrected for by the appropriate means. Estimates of the price-responsiveness of scrap supply in both short-run and long-run terms could then be obtained by econometrically estimating an equation of the following type:

$$
Q_{\mathrm{t}}=\beta_{\mathrm{o}}+\beta_{1} \mathrm{P}_{\mathrm{t}}+\beta_{2} \mathrm{Q}_{\mathrm{t}-1}
$$

where $\quad Q_{\mathrm{t}}=$ quantity of scrap supplied at time $\mathrm{t}$

$$
\begin{aligned}
\mathrm{Q}_{\mathrm{t}-\mathrm{b}}= & \text { quantity of scrap supplied during the } \\
& \text { previous time interval } t-1
\end{aligned}
$$

$P_{t}=$ price of scrap at time $t$

$$
\beta_{0}, \beta_{1}, \beta_{2}=\text { constants }
$$

Here, the present quantity of scrap supplied is taken to be a function both of the present price of scrap and of the supply of scrap in the period immediately preceding the present. It may be helpful to think of this latter term as an "inertia factor" which describes the importance of recent activity levels in determining the current level. Given this specification of the pricequantity relationship, it is easy to follow through the effects of an increase in the price of metal. The immediate impact of the price increase is indicated by the response parameter $\beta_{1}$, which predicts some resulting increase in scrap output during the period in question.

Now, note that the current period's output $\mathrm{Q}_{\mathrm{t}}$ will become $\mathrm{Q}_{\mathrm{t}-1}$ in the next period. The price increase will therefore make itself felt again in the future, and some "echo" effects will still be present several periods hence. This is the simplest sort of dynamic equation, which can be solved by considering the situation after a once-for-all price increase has worked its way through the system. Once the transient price effect has been completely dampened by the passage of time, the condition $\mathrm{Q}_{\mathrm{t}}=\mathrm{Q}_{\mathrm{t}-1}$ will prevail. Substituting appropriately into the original equation gives the following long-run equilibrium condition:

$$
\begin{gathered}
Q_{t}=\beta_{0}+\beta_{1} P_{1}+\beta_{2} Q_{t} \\
Q_{t}-\beta_{2} Q_{t}=\left(1-\beta_{2}\right) Q_{t}=\beta_{0}+\beta_{1} P_{t} \\
Q_{t}=\beta_{0} /\left(1-\beta_{2}\right)+P_{t} \beta_{1} /\left(1-\beta_{2}\right)
\end{gathered}
$$


The appropriate measure of the long-run impact of the price increase now appears to be the parameler $\beta_{1} /\left(1-\beta_{2}\right)$. Thus, the appropriate means for estimating the long-run effect is implicit in the original specification of the scrap supply equation.

While this kind of lagged-effect model is quite useful for distinguishing between short- and long-run price responsiveness, it is subject to another set of serious econometric problems that must be accounted for. Professor Ray Fair has developed an appropriate correction technique.(2) Any estimation of an equation of the above type that does not employ the Fair technique is not to be trusted because the parameter values will be biased away from the true values in systematic ways.

Some attention should also be devoted to the units in which the relevant variables are measured. Equation (1) above is in what is generally termed the "linear" form, and the parameter values indicate the short- and long-term changes in scrap output (measured in whatever units have been employed for the econometric work - most probably thousands of tons) that will result from a one-unit change in scrap price (generally, price is measured in cents/lb, or $\$ /$ ton). Although it has been convenient to use this linear equation form in introducing the notion of short- and long-run response measurement, the implied relationship between scrap supply and scrap price is not, in fact, a very realistic one. Generally, the workings of the market are captured much bettcr by equations that describe responsiveness in proportional terms. Equations that are linear in the logarithms of the relevant variables have this property. Suppose, for example, that the original supply equation was respecified in the following way:

$$
\log Q_{t}=\beta_{0}+\beta_{1} \log P_{t}+\beta_{2} \log Q_{t-1}
$$

In this "log-linear" form, the estimated parameters can be interpreted as ratios of percentage changes. Thus, $\beta_{1}$ in this revised form would measure the percent change in quantity that would result from a percent change in price in the short run, and similarly for $\beta_{1} /\left(1-\beta_{2}\right)$ in the long run. Since these interpretations coincide precisely with the standard definition of price elasticity of supply, the log-linear specification is quite convenient for empirical work.

\subsubsection{Statistical Questions}

Typically, the parameter values for equations like those above are estimated using a computer algorithm that minimizes the sum of the squared differences between the actual supply obscrvations and the observations that would be predicted by the simple model specified. These "least-squares" estimates are no more than approximations, of course, and the history they describe is only one sample from a multitude of possible outcomes. Had history been allowed to repeat itself, the observed supply levels would undoubtedly have been different, even if the associated prices had been exactly the same. To acknowledge this is simply to acknowledge the role of random changes in the environment for which the simple model does not compensate.

Thus, observations used for "least-sruares" estimation are roally random draws from the population of possible outcomes, and the resulting parameter estimates must be subject to uncertainty. Using linear algebra and the Central Limit Theorem of Statistics, econometricians have been able to devise a means for estimating the range within which the "true" parameter values for any equation probably lie, given only the assumption that intervening changes in the environment are essentially random. In most reports of econometric results, the estimated uncertainty level is presented as the "standard error" of the estimaled parameter. A good rule of 
thumb for constructing the range within which the true parameter could plausibly lie is to double the reported standard error, add it to the estimated parameter value to form the upper bound for the plausible range, and subtract it from the estimated parameter to form the corresponding lower bound. As an example, suppose that a log-linear supply equation has been estimated for scrap with the following results (the estimated standard errors are included in parentheses underneath the estimated parameter values):

$$
\log Q_{t}=1.26+0.49 \log P_{t}+0.27 \log Q_{t-1}
$$

Using the calculated standard errors, the interval within which the true short-run price elasticity can be plausibly supposed to lie will be:

$$
0.31 \leq \beta_{1} \leq 0.67
$$

At the same time, the best estimate of the long-run elasticity will be:

$$
\left(\beta_{1} / 1-\beta_{2}\right) \equiv 0.49 / 1-0.27=0.67
$$

Obviously, there is an illusory degree of certainty that will prevail if only the estimated parameter values themselves are considered. At the same time, thcre is a good argument for considering the actual parameter estimates as the best ones, if only one prediction of the consequences of a price change is needed.

As a conclusion to this general discussion of econometric estimation of price responsiveness equations, a word should be said about the interpretation of $\mathrm{R}^{2}$, which is commonly used as the measure of the degree to which an equation has successfully "explained" the observed variation in the hehavior of some variable (in this case, the supply of scrap). In econometric work that involves the analysis of movements of variables through time, $\mathrm{R}^{2}$ is frequently of little practical use. Given the tendency of variables such as output to exhibit persistent strong trends and the fact that conventional supply equations frequently specify present output as a function of past output (among other things), it is not at all surprising that such equations tend to exhibit very high $\mathrm{R}^{2}$ values. Such a high value obviously does not mean much when the behavior of a variable is being "explained" by its own behavior in the immediate past. Thus, the important measures in econometric estimates of supply behavior are the parameter values and the standard errors, not the estimated $R^{2}$ values.

\subsection{METHODOLOGY}

\subsubsection{Methodology Overview}

This section describes the general methodology established by.DOE for the metals, pulp and paper, rubber, and textile industries. ${ }^{(3)}$

Figure 2-2 indicates a series of steps required for developing draft targets for rccoverable materials (RM) for all industries. 'These steps are discussed below. 


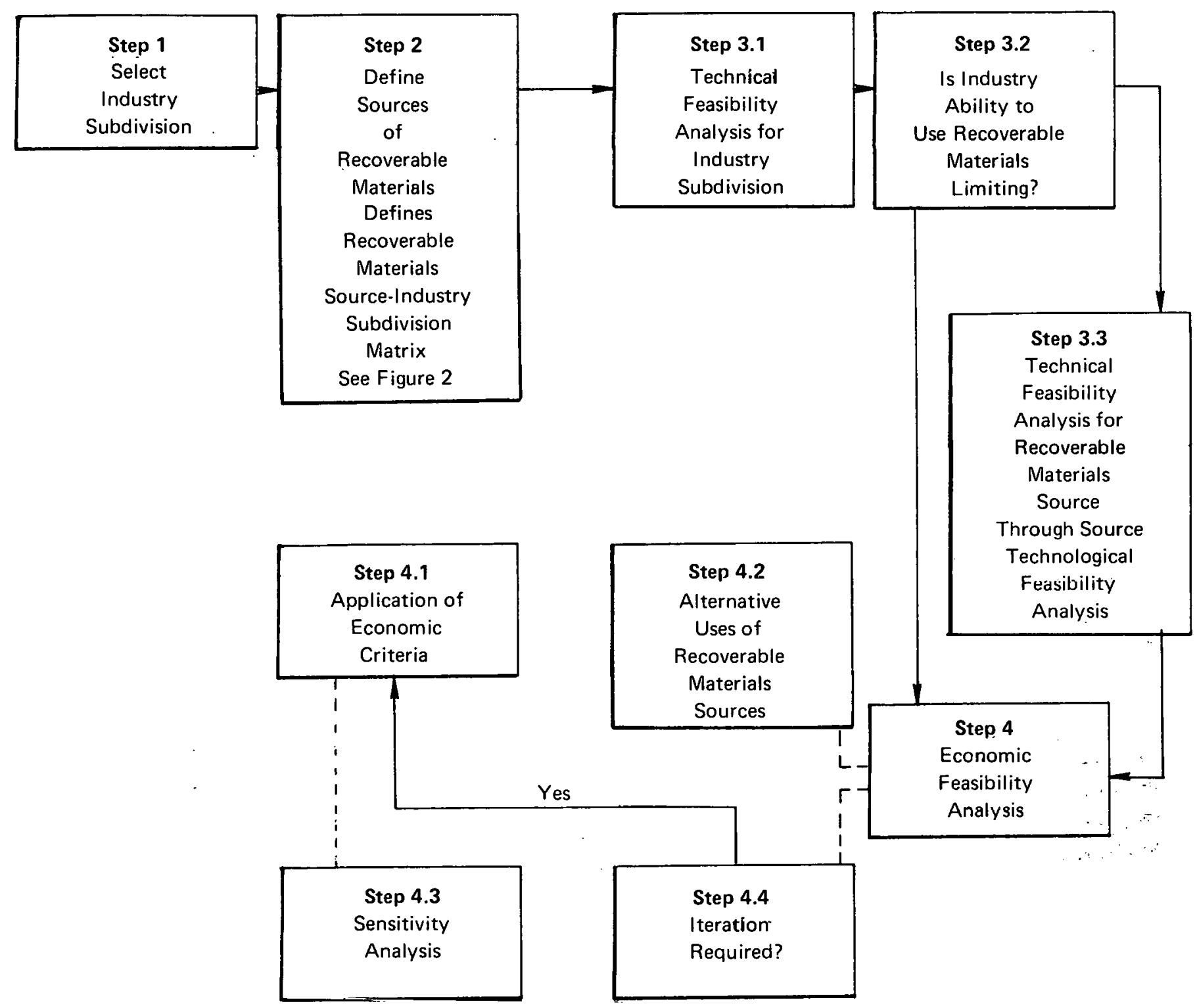

FIGURE 2-2 METHODOLOGY NETWORK ENERGY SAVING RECOVERED MATERIALS TARGETS 
A. The following factors were considered in determining portions of an industry to be studied further:

1. Historical and current use of recovered materials in the industry

2. Sales of industry components

3. Energy consumption levels

4. Parts of the industry that historically and currently use recovered materials

5. Potential for use of recovered materials between now and 1987

6. All materials identified in the legislation.

B. Portions of the industry (e.g., fabricating plants) were excluded from further consideration since additional study of these segments would not contribute anything useful to the results.

C. Each industry segment was carefully studied to determine whether an SIC, process, product type (other than SIC) or some other sub-division of the industry was most appropriate.

D. The result of Step 1 was one ordinate of the "industry RM source matrix," shown in Figure 23.

Step 2: Select Sources of Recoverable Materials

A. The following factors were considered in determining sources of recoverable materials:
1. Quality of waste
2. Dispersion of waste
3. Quantity of waste
4. Potential new sources, and their quality, dispersion, quantity, etc.
5. Changes in existing sources.

B. Sources of RM do include:

1. Wastes that contain materials listed in the Act (e.g., mine wastes). (As discussed in Section 2.2.1, however, mine wastes do not meet the economic feasibility criterion in the legislation.)

2. Wastes frum outside the United States (none were found).

3. Any waste that may provide RM to replace any virgin material used by any of the industry subdivisions defined in Step 1.

C. Snıırees of RM do not include:

1. Waste materials not among those listed in the Act (none were found).

2. Situations where a clear case can be made that the potential sources will never be realistically used as RM, for whatever reason - technical, economic, institutional, etc. 


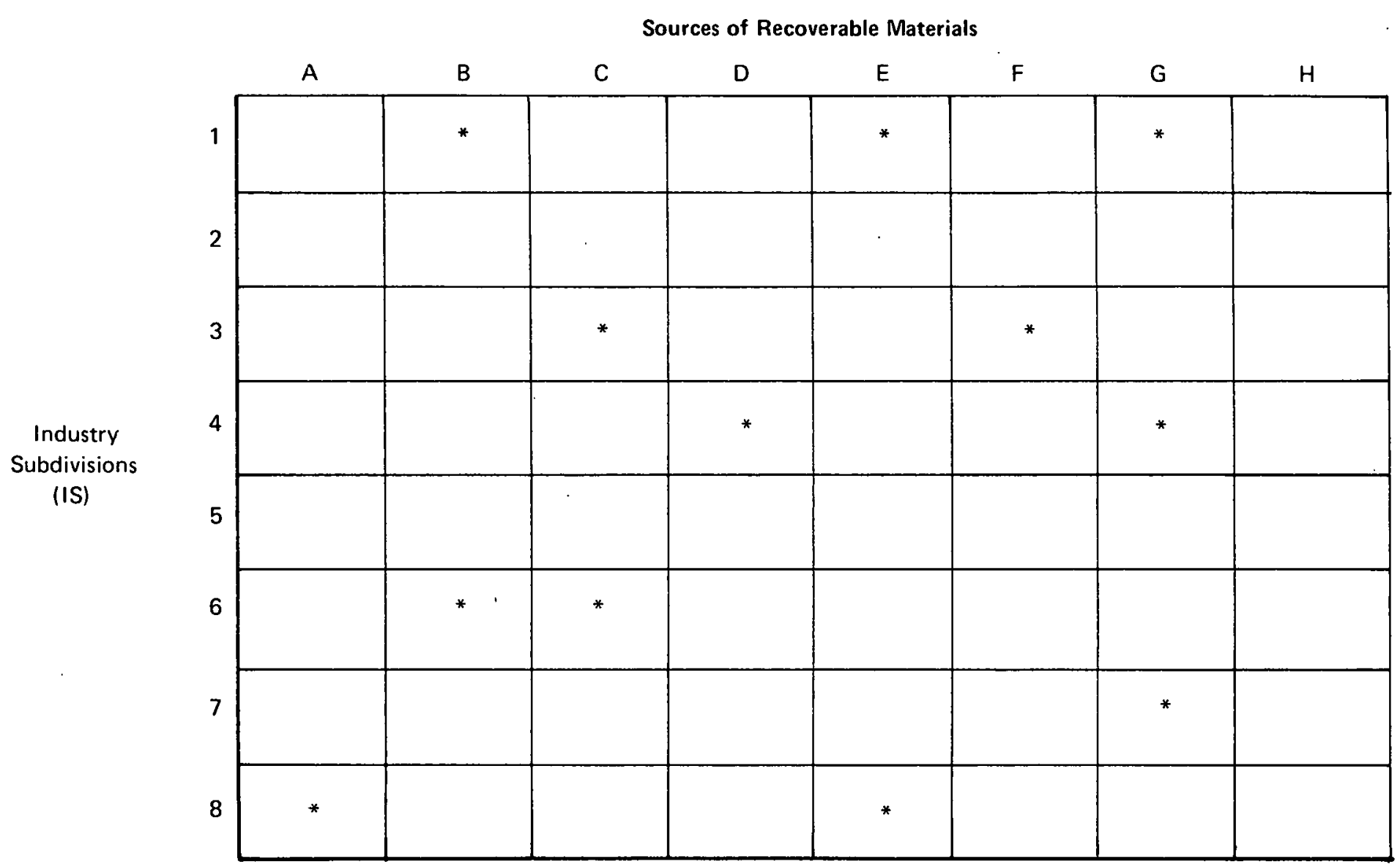

Objective: Define $\%$ output of IS, where $x$ is the economically feasible amount of recovered materials for each Industry Subdivision. 
3. Waste materials generated and introduced back into the process within the same plant. Because home scrap and prompt industrial scrap are identical except for the absence/presence of a transaction, home scrap was tracked as a separate category when data were available. Since almost all home scrap is recycled, this does not affect any draft target.

D. The result of Step 2 is completion of the basic "industry RM source matrix," shown in Figure 2-3. This figure shows present and future sources for recovered materials for an industry subdivision.

\section{Step 3: Technological Feasibility Analysis}

A. Current and historical use of RM within each industry sub-division, by source of RM, for each source defined by a marked cell in the matrix was quantified wherever data were available.

B. Present technical limits on industry's ability to utilize RM were analyzed. Typically, such limits are related to an industry's existing equipment and plant (capital stock).

C. Future technical limits represented by decisions already made (e.g., plant expansions, new plant construction, etc.) were determined.

D. Realistic technologies that could alter these technical limits were assessed if they could be physically in place and operational between now and 1987, and could have some minimum level of impact on use of the recovered material.

\section{Step 4. Econumic Feasibility Anulysis}

The approach used in the economic analysis by Arthur D. Little, Inc., was adapted from DOE's guidelines. Arthur D. Little's approach used econometric techniques to estimate the supply of scrap in 1987. Since the purpose of this project is to increase energy savings via the use of recovered materials, it is important to remember that the ferrous industry (iron and steel, ferrous foundries, and ferroalloys), as defined here, accounts for approximately $83 \%$ of the energy consumed in the metals sector (i.e., SIC 33), aluminum for about $11 \%$, copper for about $3 \%$, and all others for the remaining $3 \%$. Energy consumed in the lead and zinc segments is less than $1 \%$ each. 'I'herefore, most of the effort in econometric modeling was focused on the ferrous scrap users, followed by aluminum and copper. For lead and zinc, draft targets were estimated on the basis of published forecasts of trends in these industries relating to growth rates, changes in industry structure and changes in market structure.

A. Actions that affect the target: Major actions that could realistically increase the use of RM by a defined industry subdivision were addressed. These incentives could be financial, regulatory, institutional, etc. in nature.

B. Sensitivity analysis: The sensitivity of the target to key economic variables was addressed.

C. Upon completion of Step 4, the economically feasible level of RM use by each industry subdivision was defined. 


\subsection{IMPACT OF GOVERNMENT ACTIONS ON RECYCLING}

Many government policies can potentially have an impact on the degree of recycling in all types of primary and secondary metals industries. The significant areas are:

- Tax Policy

- Freight Rates

- Product Specifications

- Residuals (pollution control)

- Market:Structure

- Export Controls on Scrap 


\section{REFERENCES}

\section{REFERENCES: SECTION 2.0 INTRODUCTION}

1 Fink, D.A., Market Structure and Recycling in the Nonferrous Metals Industries, Resource Conservation, D.W. Pearce \& I. Walter eds., New York: New York University Press, 1977.

2 Fair, Ray C., Estimation of Simultaneous Equation Modẹls with Lagged Endogenous Variable and First Order Serially Correlated Errors, Econometrica, 28, 507-516, May 1970.

3 Gross, T., Energy Saving Recovered Materials Targels Guidance to Methodology, Internal Memorandum, Department of Energy, January 10, 1979. 


\subsection{INDUSTRY PROFILE}

\subsection{INTRODUCTION}

This section presents general profiles for the major industrial segments comprising SIC 33. The profiles include such topics as industry structure, process technology, materials and recycling flow, and future trends. These profiles are designed to give a general overview of the respective industry segments as well as to provide a framework with which to analyze current and future recycling practices.

\subsubsection{Definition of SIC 33}

As defined by the U.S. Office of Management and Budget, this major industrial group includes "establishments engaged in the smelting and refining of ferrous and nonferrous metals from ore, pig or scrap; in the rolling, drawing and alloying of ferrous and nonferrous metals; in the manufacture of castings and other basic products of ferrous and nonferrous metals; and in the manufacture of nails, spikes and insulated wire and cable." Establishments engaged primarily in manufacturing metal forgings or stampings are classified in SIC 34 and are, therefore, excluded from this analysis.

\subsubsection{Subdivision of SIC 33 by Industry Groups}

In order to facilitate data collection, analysis and presentation, the major industry group, SIC 33, was subdivided into six four-digit SIC categories. Each of the four-digit SIC categories was reviewed to eliminate sections not pertinent to recycling. For example, SIC 3398 (Metal Heat Treating) does not involve recycling and is, therefore, excluded from further analysis. The remaining four-digit SIC categories were regrouped into five major industrial metal categories:

- Ferrous Industry (including Iron \& Steel, Ferrous Foundries, and Ferroalloys)

- Aluminum

- Copper

- Zinc

- Lead

The resulting industry subdivisions and the SIC categories included are given below:

\section{Industry Subdivision}

Ferrous Industry

Aluminum

Copper

Zinc

Lead

\section{SIC Categories}

$3312,3315,3316,3317,3321$, $3322,3324,3325,3313$

$3334,3353,3354,3355$, (33417) (33418)

$3331,3351,(33412)$

3333, (33414)

3332, (33413)

1. SIC 3341 has been allocated by a five-digit SIC number into the appropriate major industrial categories. 
Industry profiles for each subdivision are described in the following sections.

\subsection{FERROUS}

\subsubsection{Industry Definition}

The Ferrous Industry is comprised of the following segments:

- Iron and Steel, which includes SIC 3312, 3315, 3316 and 3317;

- Ferrous Foundries, which includes SIC 3321, 3322, 3324 and 3325;

- Ferroalloys, which includes SIC 3313.

\subsubsection{Iron and Steel}

SIC 3312 includes "establishments primarily engaged in manufacturing hot metal, pig iron, silvery pig iron, and ferroalloys from iron ore and iron and steel scrap; converting pig iron, scrap iron and scrap steel into steel; and in hot rolling iron and steel into basic shapes such as plates, sheets, strips, rods, bars and tubing and cold finishing and processing these products in the same plant." Also included are merchant blast furnaces.

SIC 3315 is comprised of "establishments primarily engaged in drawing wirc from purchased iron or steel rods, bars, or wire and which may be engaged in the further manufacture of products made from wire." Also included in this segment are establishments primarily engaged in manufacturing steel nails and spikes from purchased materials.

SIC 3316 includes those "establishments primarily engaged in (1) cold rolling steel sheets and strip from purchased hot rolled sheets, (2) cold drawing steel bars and steel shapes from purchased hot rolled steel bars and (3) producing other cold finished steel."

SIC 3317 is composed of those "establishments primarily engaged in the production of welded or seamless steel pipe and tubes and heavy riveted steel pipe from purchased malerials."

\subsubsection{Ferrous Foundries}

The domestic ferrous foundry industry includes establishments primarily engaged in manufacturing iron and steel castings. Establishments classified in other industries frequently operate their own foundry departments to produce castings to be incorporated into such products as stoves, furnaces, plumbing fixtures, motor vehicles, etc. Establishments primarily engaged in the manufacture and rolling of steel and classified in the Iron and Steel subcategory also make steel rastings.

SIC, 3321 includes establishments primarily engaged in manufacturing gray iron castings, including cast iron pressure and soil pipes and fittings. SIC 3322 primarily produces malleable iron castings. SIC 3324 primarily produces steel investment castings. SIC 3325 produces steel castings not elsewhere classified. The bulk of steel castings production falls into the SIC 3325 category.

\subsubsection{Ferroalloys}

SIC 3313 contains "establishments primarily engaged in manufacturing ferro- and nonferrous additive alloys by electrometallurgical or metallothermic processes, including high per- 
centage ferroalloys and high percentage nonferrous additive alloys." Ferroalloys produced by the hlast furnace process will also be included in the analysis for this report.

\subsubsection{Industry Structure}

\subsubsection{Iron and Steel}

The United States consistently ranks first or second among world producers of raw steel. ${ }^{2}$ Table 3.2-1 compares U.S. raw steel output with the world total for the years 1950-1976. Geographic distribution of raw steel production has shifted steadily and dramatically in that time; the United States produced nearly half of the world's steel in 1950, but only $17 \%$ by 1976 . Compared with a consistent annual growth rate of $5.8 \%$ worldwide, U.S. steel production has had only sporadic growth on the order of $1.5-2.5 \%$ annually. In 1976 , U.S. production equalled $80.9 \%$ of calculated raw steel capacity of 158 million short tons. ${ }^{2}$

The U.S. steel industry produces raw steel in some 165 steelmaking plants, ${ }^{3}$ with about $85 \%$ of the production accounted for by 15 large companics..$^{5}$ Including associated steel rerolling and steel finishing plants, the U.S. industry is composed of some 400 plants employing $520,000 .{ }^{6}$

In 1976 reported net shipments were about 90 million short tons. ${ }^{4}$ Total revenues for firms accounting for nearly $90 \%$ of the nation's raw steel production (128 million short tons) amounted to about $\$ 36.4$ billion. $^{5}$

The iron and steel industry consumed about $70 \%$ of all energy used in the SIC 33 classification in 1976. Purchased energy consumption by SIC category for the iron and steel industry is given in Table 3.2-2 for 1974-1976.

Plants producing raw steel may be categorized into three broad groups - fully integrated, cold metal shops and non-integrated. Fully integrated plants are engaged in both iron and steelmaking operations. The integrated plants start with iron ore and coking coal, from which pig iron (or hot metal) is produced in blast furnaces. The resulting hot metal, along with scrap, is charged into steelmaking furnaces to produce molten raw steel, which is subsequently cast and fabricated to finished steel products. In 1976, a total of 58 integrated plants were in operation. ${ }^{3}$

The cold metal shops operate their steel furnaces with cold metal charge - scrap, pig iron, or, more recently, sponge iron made by direct reduction - which is melted and refined in the steelmaking furnaces. These plants do not produce hot metal from ore. Most cold metal plants in the United States use electric arc furnaces, which offer economic advantages and flexibility of operation. A special group of smaller cold metal plants comprises the so-called mini-mills; many of these mills have annual capacities of less than 200,000 short tons and limit their production to bar mill products, rebars and merchant bars. In 1976, a total of 107 cold metal plants were in operation. ${ }^{3}$.

The third category of plants in the steel industry are the non-integrated plants. These plants purchase semi-finished steel from integrated or cold metal producers for finish rolling and additional fabrication to final products. Many of the non-integrated plants are satellite finishing operations for the raw steel producers. This group includes facilities that reroll carbon steel products and others that finish alloy steel intermediates. 
TABLE 3.2-1

RAW STEEL PRODUCTION: $1950-1976$

$$
\begin{aligned}
& \text { Production } \\
& \text { (million short tons) }
\end{aligned}
$$

\begin{tabular}{|c|c|c|c|}
\hline Year & World & U.S. & $\begin{array}{l}\text { U.S. as \% of } \\
\text { the World }\end{array}$ \\
\hline 1950 & 207 & 97 & 46.9 \\
\hline 1952 & 234 & 93 & 39.7 \\
\hline 1954 & 246 & 88 & 34.8 \\
\hline 1956 & 313 & 115 & 36.7 \\
\hline 1958 & 299 & 85 & 28.4 \\
\hline 1960 & 382 & 99 & 29.5 \\
\hline 1962 & 395 & 38 & 24.8 \\
\hline 1964 & 479 & 127 & 26.5 \\
\hline 1966 & 519 & 134 & 28.8 \\
\hline 1968 & 583 & 131 & 22.5 \\
\hline 1970 & 654 & 132 & 20.2 \\
\hline 1971 & 640 & 121 & 18.9 \\
\hline 1972 & 694 & 133 & 19.2 \\
\hline 1973 & 763 & 151 & 19.6 \\
\hline 1974 & 783 & 146 & 18.6 \\
\hline 1975 & 712 & 117 & 16.4 \\
\hline 1976 & 753 & 128 & 17.0 \\
\hline
\end{tabular}

Source: AISI Statistical Reports, 1950-1977 
TABLE $3.2-2$

PURCHASED ENERGY USE IN THE IRON AND STEEL

INDUSTRY BY SIC CATEGORY - 1974-1976

\begin{tabular}{lrrr} 
& \multicolumn{3}{c}{ Purchased Energy Consumption, $10^{12}$ Btu } \\
\cline { 2 - 4 } SIC Category & $\underline{1974}$ & $\underline{1975}$ & $\underline{1976}$ \\
3312 & 1599.5 & 1321.8 & 1427.4 \\
3315 & 15.4 & 12.2 & 13.7 \\
3316 & 19.8 & 13.4 & 15.8 \\
3317 & 18.1 & 15.3 & 12.2
\end{tabular}

Source: U.S. Department of Commerce, Annual Survey of Manufacturers, "Fuels and Electric Energy Consumed", 1974-1976. 
The six states bordering the Great Lakes - New York, Pennsylvania, Ohio, Indiana, Illinois, and Michigan - have historically accounted for over $75 \%$ of total U.S. steel output. ${ }^{2}$ Within these states are about $80 \%$ of the integrated plants and $70 \%$ of the cold metal and nonintegrated steel plants. ${ }^{3}$ This industry concentration results from the favorable location of raw material sources, transportation arteries, and steel-consuming industries. ${ }^{2}$

\subsubsection{Ferrous Foundries}

In 1976 , more than 1750 ferrous foundry plants were in operation, and the industry produced about 16.8 million short tons of castings valued at $\$ 10$ billion (Table 3.2-3). The industry makes metal parts that range from tiny, specialized stainless steel heart valves to huge components for machine tools and hydroelectric turbines. Purchased energy consumption by ferrous foundries for 1976 equalled $155.0 \times 10^{12} \mathrm{BTU}$ equivalents. Of this amount, gray (including ductile) iron foundries consumed $67 \%$, steel foundries $23 \%$ and malleable iron foundries $10 \%{ }^{7}$

Gray iron foundries are the largest segment of the ferrous foundry industry with $68 \%$ of total output in $1976 .{ }^{6}$

In 1976 , a total of 1195 foundries poured gray iron as their major product. About $80 \%$ of these foundries were small, employing fewer than 250 employees. ${ }^{6}$ However, the number of small foundries has dropped dramatically over the past 15 years and this trend is expected to continue.

Gray iron foundries are concentrated in the Great Lakes region, but the industry is dispersed across the nation with plants located in all 50 states. Gray iron foundries have a strong jobbing orientation, and $62 \%$ of the establishments sell all of their output to outside customers. ${ }^{6}$

Production of ductile iron castings started in the United States in the late 1940's, and has had the highest growth rate of all cast ferrous materials over the last 20 years. ${ }^{6}$ The physical properties of ductile iron are close to those of carbon steel, and can be produced in a manner similar to gray iron. Consequently, a large part of the growth of ductile iron has been at the expense of other ferrous castings.

In 1976, 88 foundries produced ductile iron as their major metal product. Of these, $42 \%$ had 50-250 employees and 37\% had 10-49 employees. ${ }^{9}$ Most of the ductile iron foundries are located in the Great Lakes and East South Central regions and most are iob-oriented with $60 \%$ of the foundries selling all of their output. ${ }^{6}$

Malleable iron has been produced since the 1800's. Its position in the industry is now relatively minor in terms of tonnage and value of shipments. Because production of malleable iron is energy-intensive, its position in the future will be even less competitive.

In 1976, 59 foundries produced malleable iron castings as their major product. Most of these were large foundries with about half having more than 250 employees. ${ }^{9}$ The malleable iron foundries are concentrated in the Great Lakes and Middle Atlantic regions and $66 \%$ of them are independent jnhhers. ${ }^{6}$

Steel is the second largest segment of the ferrous foundry industry. More than $95 \%$ of production is carbon and low alloy steel, with the remainder high alloy material. ${ }^{6}$ Most of the 
TABLE 3.2-3

NUMBER OF FOUNDRIES AND CASTING SHIPMENTS - 1976

\begin{tabular}{|c|c|c|c|}
\hline \multirow[t]{2}{*}{ Major Metal Cast } & \multirow[t]{2}{*}{$\begin{array}{c}\text { Number of } \\
\text { Establishments }\end{array}$} & \multicolumn{2}{|c|}{ Shipments } \\
\hline & & $\begin{array}{l}\text { thousands } \\
\text { of tons }\end{array}$ & $\begin{array}{c}\text { millions } \\
\text { of dollars }\end{array}$ \\
\hline Gray Iron & 1,195 & 11,900 & 7,010 \\
\hline Ductile Iron & 88 & 2,200 & \\
\hline Malleable Iron & 59 & 850 & 740 \\
\hline Steel & 422 & 1,800 & 2,330 \\
\hline Total & 1,764 & 16,750 & 10,080 \\
\hline
\end{tabular}

Source: Bureau of Census

Arthur D. Little, Inc., estimates

Penton Publications 
output goes to railroad equipment and heavy capital goods. The main advantages of steel castings are weldability, strength, ductility, and impact resistance; premium price and casting difficulties limit its applicability.

Steel foundries have been steadily declining and numbered only 422 in 1976 . Of these, about $80 \%$ had fewer than 250 employees. ${ }^{6}$ Steel foundries are heavily concentrated around the Great Lakes and Middle Atlantic regions. These foundries are also jobbing oriented with $69 \%$ being independent producers. ${ }^{6}$ The present trend is toward even more jobbing orientation.

\subsubsection{Ferroalloys}

In 1976, 33 companies in the United States operated a total of 54 ferroalloy-producing plants in 18 states and employed approximately 8,300 people. ${ }^{3}$ Eleven companies operated more than one plant. A list of plants is given in Table 3.2-4. These plants produced 1.9 million short tons of ferroalloys valued at close to $\$ 1$ billion (Table 3.2-5). ${ }^{10}$ Ferroalloys containing either manganese, silicon, or chromium accounted for slightly over $90 \%$ of production. ${ }^{10}$ These materials were produced by 19 companies, which operated 37 plants. ${ }^{10}$

\subsubsection{Process Technology}

\subsubsection{Iron and Steel}

The flow of material and the functions of the unit operations in the iron and steelmaking and steel-forming sequences of an integrated plant are portrayed in Figure 3.2-1. The left side of the figure represents the iron and steelmaking end and shows the flow of raw materials into hot metal (molten pig iron) and steel. Along with scrap (about half of which is recycled from subsequent operations) the hot metal may be fed into any of three different types of refining furnaces to produce molten steel. The molten steel is then either cast into ingots and rolled in primary breakdown mills to semifinished forms by conventional praclice, or direct cast into semifinished forms (blooms, slabs, or billets) by the continuous casting process. As indicated in the figure, the semifinished raw steel is routed through various rolling mills to be finished into a wide range of products such as structural shapes, bars, plates, and hot or cold rolled sheet.

The principal components of the iron and steel technology that are relevant to this study are:

- Sinter plant

- Blast furnace (for producing pig iron)

- Direct reduction (for producing prereduced iron)

- Panaic oxygen furnacc

- Open hearth furnace

- Electric arc furnace

- Continuous casting

- Rolling and finishing operations 
TABLE $3.2-4$

FERROALLOY PRODUCERS

PRODUCER

AIRCO ALLOYS DIV.

Airco, Inc.

3801 Highland Ave.

Niagara Falls, NY

ALABAMA ALLOY CO, INC

Bessemer, AL

CHROMIUM MINING \&

SMELT ING CORP. DIV.

Chromasco Ltd.

Memphis, TN

CLIMAX MOLYBDENUM CO.

Div. of Amax, Inc.

1270 Ave. of Americas

New York, NY

DIAMOND SHAMROCK CORP.

Chemetals Div.

711 Pittam Road

Baltimore, MD

DUVAL CORP.

900 Southwest Tower

Houston, TX

ENGLEHARD MINERALS \&

CHEMICALS CORP.

299 Park Avenue

New York, NY

FMC CORP.

Industrial Chemicals Div Pocatello, ID

633 Third Avenue

New York, NY

FOOTE MINERAL CO.

Ferroalloys Div.

Route 100

Exton, PA

Mobile, AL

Bessemer, AL

Woodward, AL

Woods tock, TN

Lange loth, PA

Kingwood, WV

Sahuarita, $A Z$

Rockwood, IN

Strasburg, VA

Cambridge, $\mathrm{OH}$

Graham, WV

Keokuk, IA
PLANT LOCATIONS

Calvert City, KY

Charleston, SC

Niagara Falls, NY

New Johnsonville, TN
FeMo

metallothermic

PRODUCTS FURNACE TYPE

$\mathrm{FeCr}$, FeMn electric

Fecrsi,

FeSi, SiMn

FeMo

FeSi

electric

FeCr, FeSi electric

FeMo

metallothermic

FeMn

electrolytic

reMn, FeSi electric

$\mathrm{FeV}$

metallothermic

FeP

electric

FeCrSi, FeV electric $\mathrm{FeCr}$, FeSi

FeSiMg, Mn

CaSi, silvery

pig iron 
GLOBE METALLURGICAL DIV.

Interlake, Inc.

1556. Union Commerce B $1 \mathrm{dg}$

$\mathrm{Cleveland}, \mathrm{OH}$

GULF \& WESTERN INC.

New Jersey Zinc Co.

2045 City Line Rd.

Bethlehem, PA

HANNA MINING CO.

Ion Frleview Plaza

Cleveland, $\mathrm{OH}$

HOOKER CHEMICAL DIV. Uccidental Petroleum 600 Union Street

Niagara Falls, NY

INTERNATIONAL MINERALS

\& CHEMICAL CORP.

Tennessee Alloys Div.

818 Hamilton Bank Bldg

Chattanooga, TN

KAWECKI BERYLCO IND.

P.0. Box 1462

Reading, PA

KERR MCGEE CHEMICAL

Kerr McGee Center

Oklahoma City, OK

METALLURG, INC.

Shieldalloy Corp.

West Boulevard

Newfield, NJ

MOBIL CHEMICAL CO.

Mobil 0il Corp.

150 E. 42nd Street

New York, NY

MOLYCORP, INC.

280 Park Avenue

New York, NY
Beverly, $\mathrm{OH}$

Selma, AL

Toledo, $\mathrm{OH}$

Palmerton, PA

Riddle, OR

Wenatchee, WA

Columbia, TN

FeP

electric

Bridgeport, AL

Kimball, TN

Springfield, OR

Revere, PA

$\mathrm{Si}$

$\mathrm{FeCb}$

electric

metal lothermic

Oklahoma City, OK Mn

Newfield, NJ

FeV,

FeCh, FeTi, elertrir, $\mathrm{FeAl}, \mathrm{FeB}$ metallothermic

Nichols, FL

FeP

electric

Washington, PA

FeB, FeMo

FeW

electric metallothermic 
TABLE 3.2-4. (Continued)

PRODUCER

MONSANTO COMPANY

Industrial Chemicals

$800 \mathrm{~N}$. Lindbergh Blvd.

St. Louis, MO

NAT IONAL NICKEL ALLOY

Seven Parkway Center

Pittsburgh, PA

OHIO FERRO ALLOYS

83930 th St., N.W.

Canton, $\mathrm{OH}$

THE PESSES COMPANY

29605 Hall Street

Solon, $\mathrm{OH}$

REACTIVE METALS \& ALLOYS

Niles, $\mathrm{OH}$

READING ALLOYS

P.0. BOX 53

Robesonia, PA

REYNOLDS METALS

Richmond, $V A$

SABIN METAL CORP.

310 Messerole St.

Brooklyn, NY

SATRALLOY INC.

625 Stanwix Street

Pittsburgh, PA

STAUFFER CHEMICAL C.

Industrial Chemicals Div

Nyala Farm Road

Westport, CT

TENN-TEX ALLOY CORP

Div. of Sandgate Corp.

13501 Industrial Road

Housturi, TX
PLANT LOCATIONS

Columbia, TN

Soda Springs, ID

Marietta PA

Brilliant, $\mathrm{OH}$

Philo, $\mathrm{OH}$

Powhatan Pt., OH

Montgomery, AL

Pepper Pike, $\mathrm{OH}$

Newcastle, PA

West Pittsburgh, PA

Robesonia, PA

Sheffield, AL

Brooklyn, NY

Steubenville, $\mathrm{OH}$

Mt. Pleasant, TN

Silver Bow, MT

Tarpon Springs, FL

Muscle Shoals

Houston, TX
PRODUCTS

FURNACE TYPE

FeP electric

$\mathrm{NiCr}$,

NiCrMo electric

$\mathrm{FeB}, \mathrm{FeMn}$

FeSi, Si,

SiMn

electric

FeSiAl, FeSiMg, electric, FeSiT, FeSizr, metallothermic $\mathrm{FeAl}, \mathrm{FeB}, \mathrm{FeCb}$

FeSi, FeTi electric

FeCb, Few

metallothermic

Si

electric

FeNi, rew

FeCr, FeMn, electric FeCrSi

FeP

electric

FeMn, SiMn, electric 
TENNESSEE VALLEY AUTHORITY

Muscle Shoals, AL

Muscle Shoals, AL

FeP

electric

UNION CARBIDE CORP.

Alloy, WV

Ashtabula, $\mathrm{OH}$

Metals Division

270 Park Avenue

New York, NY

Marietta, $\mathrm{OH}$

Niagara Falls, NY

Portland, OR

Sheffield, AL

UNITED STATES STEEL CORP

600 Grant Street

Pittsburgh, PA

Mckeespurt, PA

Clairton, PA

$\mathrm{FeB}, \mathrm{FeCr}$ electric

Fecrsi, FeMn, $\mathrm{FeSi}, \mathrm{FeV}$,

Fel, Si 
T.ABLE $3.2-5$

FERROALLOYS PRODUCED AND SHIPPED - 1976

\begin{tabular}{|c|c|c|c|c|}
\hline & \multicolumn{2}{|c|}{1975 Production } & \multicolumn{2}{|c|}{1976 Shipments } \\
\hline & $\begin{array}{l}\text { Gross Weight } \\
\text { (short tons) }\end{array}$ & $\begin{array}{c}\text { Alloy } \\
\text { Element } \\
\text { Contained } \\
\text { (average \%) }\end{array}$ & $\begin{array}{l}\text { Gross weight } \\
\text { (short tons) }\end{array}$ & $\begin{array}{l}\text { Value } \\
\text { (thousands \$) }\end{array}$ \\
\hline Ferromanganese & 482,662 & 79 & 494,222 & $\$ 207,505$ \\
\hline Silicomanganese & 128,917 & 66 & 132,362 & 52,649 \\
\hline Ferrosilicon & 860,799 & 57 & 890,844 & 409,726 \\
\hline \multicolumn{5}{|l|}{ Chromium Alloys } \\
\hline \multicolumn{5}{|l|}{ Ferrochromí um } \\
\hline High carbon & 167,125 & 66 & 161,757 & 82,774 \\
\hline Low carbon & 28,140 & 69 & 30,912 & 39,059 \\
\hline Ferrochromium-sil icon & 54,182 & 37 & 50,680 & 32,620 \\
\hline Other Alloys & 19,800 & 60 & 20,195 & 21,481 \\
\hline TOTAL & 269,247 & 60 & 263,544 & 175,934 \\
\hline Eerrocolumbium & 1,205 & 65 & 933 & 6,359 \\
\hline Eerrophosphorus & 110,903 & 24 & 92,689 & 11,178 \\
\hline others & 56,485 & $x x$ & 50,942 & 134,322 \\
\hline GRAND TOTAL & $1,910,218$ & $x x$ & $1,925,538$ & 997,668 \\
\hline
\end{tabular}

Source: U.S. Bureau of Mines Minerals Yearbook, 1976. 

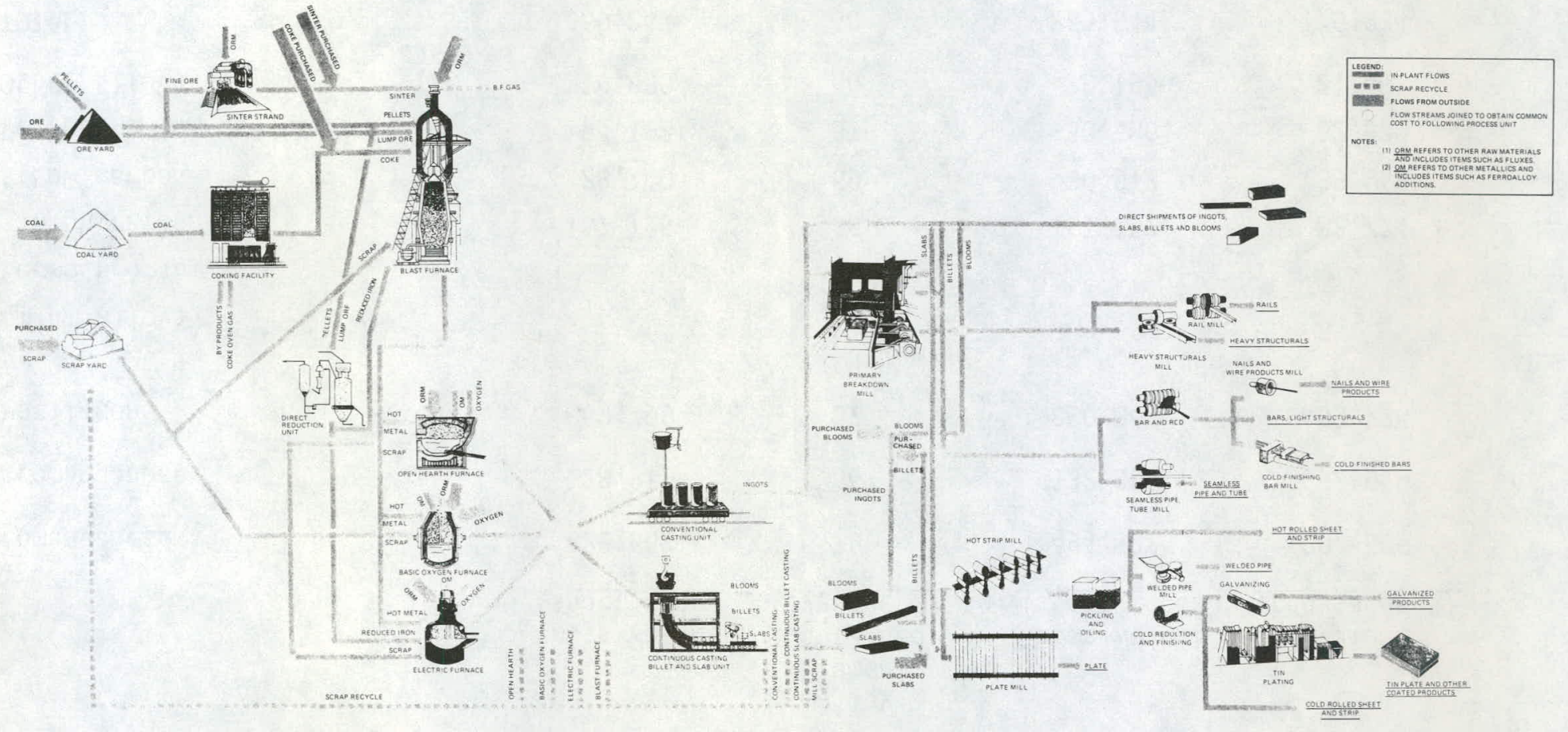

PICTORIAL REPRESENTATION OF PROCESS UNIT INTERRELATIONSHIPS - 


\subsection{Sinter Plant}

A sinter plant has the dual function of beneficiating finely divided iron ore and agglomerating various iron-bearing materials such as blast furnace flue dust, mill scale, and similar iron units generated within a steel plant. Sintered materials are more suitable for blast furnace feed than untreated materials because of improved physical properties, higher iron content, less moisture and, in some cases, less sulfur. The use of sinter in blast furnaces has significantly improved furnace performance and productivity.

A sinter machine is a continuous traveling grate. A mixture of fine ore and fine powders from various carbon sources (e.g., anthracite and coke breeze) is placed on a grate traveling over a series of windboxes. The mixture is ignited with a burner and the ignition zone moves down through the mixer as air is drawn through the ore by fans. The generated heat sinters the ore particles together into a relatively hard, porous mass.

\subsection{Blast Furnace}

The blast furnace is the workhorse of the iron and steel industry and is the basic process unit of all integrated steel plants. It is a vertical shaft reactor that burns solid carbon fuel (coke) and liquid or gaseous hydrocarbons (oil, tar, natural gas) in the presence of iron oxide rich raw materials (ore, pellets and sinter) and flux (limestone and dolomite), reducing the iron oxide to metallic iron as the burden descends. Furnace off-gases are cleaned to supply șome of the plant fuel needs, and the recovered flue dust is usually sent to the sinter plant for recycling. As a result of improvements, blast furnace production records have increased markedly from about 1200 to 10,000 short tons per day over the past 30 years. ${ }^{(11)}$

\subsection{Direct Reduction}

Many direct reduction processes have been developed, but only a few have been commcrcialized. Of these, the static bed reduction prucesses and shaft furnace account for most of the world's installed direct reduction capacity. Both processes utilize gaseous reductants. The only static bed process used on a commercial basis is the HyL process. The shaft furnace processes now operated in this country are the Midrex process and the Armco process, while other available processes include the Purofer process, as well as several others.

Direct reduction/arc-furnace combination plants may be increasingly attractive to the developing countries in the future as an alternative route to conventional steelmaking, especially in the lower capacity ranges, and when plentiful supplies of low-cost natural gas or other fossil fuels are readily available. However, at the present time direct reduced iron is not a large scale viable alternative in the U.S. mainly because of the limited supply of natural gas.

\subsection{Basic Oxygen Furnace}

The BOF process was first introduced into the United States in 1954; since that time raw steel production by this process has grown to more than 80 million short tons. ${ }^{4}$ This growth has been largely at the expense of the less economical open hearth shops. This is shown in Table 3.2-6.

Hot metal from blast furnaces is the largest and most important source of iron for the BOF, and usually comprises $70.80 \%$ of the ferrous charge materials. ${ }^{4}$ Other metallic charge materials include scrap and cold pig iron. 
TABLE 3.2-6

BASIC OXYGEN STEEL PRODUCTION - 1957-1976

(thousand)

\begin{tabular}{|c|c|c|c|}
\hline Year & $\begin{array}{c}\text { Total Raw } \\
\text { Steel Production }\end{array}$ & $\begin{array}{c}\text { Basic 0xygen } \\
\text { Production }\end{array}$ & $\begin{array}{l}\text { Basic Oxygen Steel } \\
\text { as \% of Total Raw } \\
\text { Steel Production }\end{array}$ \\
\hline 1957 & 112,715 & 611 & 0.5 \\
\hline 1958 & 85,255 & 1,323 & 1.6 \\
\hline 1959 & 93,446 & 1,864 & 2.0 \\
\hline 19.60 & 99,282 & 3,346 & 3.4 \\
\hline 1961 & 98,014 & 3,967 & 4.0 \\
\hline 1962 & 98,328 & 5,553 & 5.6 \\
\hline 1963 & 109,261 & 8,544 & 7.8 \\
\hline 1964 & 127,076 & 15,442 & 12.2 \\
\hline 1965 & 131,462 & 22,879 & 17.4 \\
\hline 1966 & 134,101 & 33,928 & 25.3 \\
\hline 1967 & 127,213 & 41,434 & 32.6 \\
\hline 1968 & 131,162 & 48,812 & 37.1 \\
\hline 1969 & 141,262 & 60,236 & 42.6 \\
\hline 1970 & 131,514 & 53,330 & 48.7 \\
\hline 1971 & 120,443 & 63,943 & 53.1 \\
\hline 1972 & 133,241 & 74,584 & 56.0 \\
\hline 1973 & 150,799 & 83,260 & 55.2 \\
\hline 1974 & 145,720 & 81,552 & 56.0 \\
\hline 1975 & 116,642 & 71,801 & 61.6 \\
\hline 1976 & 128,000 & 79,918 & 62.4 \\
\hline
\end{tabular}

Source: AISI Annual Statistical Reports, 1956-1976 
After charging the furnace with metallics, oxygen is injected and lime and fluorspar fluxes are added. Carbon, ferromanganese, ferrosilicon, aluminum, etc. may be added as the steel is tapped into a ladle. Occasionally, alloys are charged to the furnace immediately before tap, but these are usually metals that do not readily oxidize - such as nickel, copper and molybdenum.

\subsection{Open Hearth Furnace}

The open hearth process, for many years the mainstay of the domestic steel industry, has yielded to the dominance of the basic oxygen processes during the last ten years. In fact, because of relatively unfavorable economic and environmental factors surrounding the operation of open hearth furnaces, it is doubtful whether any more such plants will be built in the United States.

Scrap with hot metal is charged to the furnace and heated to melting. Ordinarily, the percentages of scrap and hot metal vary between $40 \%$ and $70 \%$ of the charge, although the furnace is capable of running the full range up to $100 \%$ scrap or hot metal. The melt is then "worked" by adding the necessary fluxing and oxidizing materials to refine the bath.

\subsection{Electric Arc Furnace}

The first electric arc furnace in the U.S. iron and steel industry was installed in 1906. By 1976, electric furnace steel production was 24.6 million short tons or $19.3 \%$ of domestic raw steel production. ${ }^{2}$

Steel scrap is the principal raw material for electric furnace steelmaking. Sponge iron from direct reduction has also been found to be practical for up to $100 \%$ of the charge; if this raw material is available at a competitive price, it is expected to be more important in the future. ${ }^{12}$

The capacity of electric arc furnaces has increased from the 4 short tons per heat of the original 1906 furnace to 400 short tons per heat in what is believed to be the world's largest electric arc steelmaking furnace. ${ }^{3}$

The process is characterized by flexibility of operation and close control of heat chemistry. Therefore, it may be used to produce the full range of carbon, alloy, structural, specialty, stainless and tool steels, and even some superalloys.

\subsection{Continuous Casting}

In continuous or strand casting, molten steel is converted directly into billets, blooms, or slabs in one continuous operation. This process bypasses the traditional steps of ingot casting, heating the solidified ingots in soaking pits, and primary shaping of the ingots in suitable mills to smaller semifinished forms. The process can result in improved product, superior surface conditions, and better metallurgical quality as well as considerable energy savings. ${ }^{12}$

Continuous casting affects the quantity of home scrap generated in the U.S. steel industry and therefore, the consumption of purchased scrap. In 1976 about $12 \%$ of steel in the United States was produced by continuous casting. ${ }^{12}$ This proportion is expected to grow in the years ahead. 


\subsection{Rolling and Finishing Operations}

The rolling and finishing operations in the steel industry can be broken down into:

- Primary Breakdown Mills

- Hot Strip Mills

- Cold Strip Mills

- Bar and Rod Mills

- Pipe and Tube Mills

- Major Structural Mills

The massive ingot (which usually weighs from a few short tons up to 40 short tons) cast from raw steel must be rolled or forged to convert it to the shapes and dimensions desired hy the st.eel consumers. Thus, the first step in the processing of the ingot in the primary shaping oneration is hot rolling to intermediate shapes suitable for further processing.

The basic primary mill is a blooming mill. Most blooms have square or rectangular crosssections, but they can also be round. The cross-section edge dimension or diameter of a bloom usually ranges from 6 inches up to one foot or more. Blooms are similarly converted to billets with section edge dimensions reduced to a few inches; which are subsequently rolled to smaller intermediate shapes, or dircctly to rod, bar, heavy structural shapes or rails. About one-third of the industry's ingots cast in 1976 were processed through blooming mills for conversion to "long" products - e.g., structurals, bars, rods, and wire. ${ }^{18}$

Generally, the first step in producing flat rolled products from ingots is rolling the ingot into slabs. Modern slabbing mills have rated rolling capacities from over one million short tons to greater than three million short tons per year of finished slabs. ${ }^{3}$ The finished slahs from a slabbing mill (or a continuous casting operation) are transferred to a slab yard for cooling, inspection, conditioning, and storage. The slabs are rolled to plate, whose size is limited by the dimensions of the starting slab, or to hot strip, most of which is subsequently pickled, cold rolled, oiled, and sold as such, or is coated with zinc (galvanized), tin or other materials. Some hot strip. depending on final size, is used to make welded pipes and tubes.

A third type of primary breakdown mill is the billet mill, which reduces a bloom or small ingot to a straight, square, or round billet. Billets are the feedstnok for conversion to har, rod, wire and seamless pipes. Capacities of billet mills range from about 100,000 short tons to over one million short tons per year. ${ }^{3}$

After passing through the primary breakdown mill, blooms, billets and slabs are ready to be converted to semifinished and finished products. This is accomplished either by hot rolling or by hot rolling followed by cold reduction.

Hot strip rolling mills account for about half the steel products. A modern hot strip rolling mill consists of in line roughing mill stands in tandem through which a slab is passed sequentially to reduce the starting thickness of several inches. A hot strip mill can produce semi-finished strip to widths over 6 feet and a range of thicknesses from over one-half inch down to about 0.05 inch.

To produce thin-gauge steel, the hot rolled strip or hot band must be further reduced. Since the hot strip has already been rolled to the limits of the hot strength of the metal, any further 
rolling must be done by cold rolling. The normal range of reduction in a tandem cold mill is about $80-93 \%$ of the original hot-band thickness. The cold rolled strip is cleaned and annealed for optimum properties.

Because of increased demand for lighter-gauge stock, current practice is to follow the annealing operation with a second cold reduction of the cold-rolled strip intended for tin plate. A temper mill is used to harden the surface, to restore "temper" to the annealed stock, and to prevent or minimize strain marking or breaking of the surface during subsequent operations as $w \epsilon !$. as for the double reduction for thin tin plate. For applications requiring corrosion resistance, pickled sheet and strip are galvanized by either dipping or passing the sheet through a molten bath of zinc.

Bar mills are among the oldest types of rolling units used in the steel industry. Such units have progressed from the single-stand, two-high configuration to the current multi-stand continuous mills. No other mill type has such a wide range of general-purpose products.

The rod mill was evolved along with the bar mill, and the development of looping (i.e., taking the work piece in a second pass through an intermediate stand) made possible the rolling of small rounds. The fully continuous rod mill can process longer and heavier billets and produce heavier rod bundles than older mill designs.

Bar and rod mills are other important finishing operations in the iron and steel industry. Bar mills produce bars for use in the construction industry. The important product of the rod mills is small-diameter rod for drawing to wire. Wire is made by drawing the rod through successively smaller dies. The drawn wire is then fabricated to wire products such as fencing and nails.

Seamless pipe and tube make up another important segment of the steel industry. They are produced on unique equipment specifically designed to produce only these products. Several types of welded pipe are made from hot-rolled flat stock whose width and thickness are appropriate for the size and grade of pipe.

The major structural shapes produced by the steel industry are angles, I-beams, H-columns, channels, T's, Z's and pilings, all of which are used in bridges, buildings, ships, freight cars, etc. These are produced in special mills designed for the appropriate structural shape.

\subsubsection{Ferrous Foundries}

A typical foundry can be divided into some ten interconnected operations:

- Raw materials storage and handling

- Patternmaking

- Sand preparation

- Molding

- Coremaking

- Melting

- Pouring

- Cooling

- Shakenut.

- Cleaning and finishing 
Figure 3.2-2 shows the relationships among these operations. The principal melting methods used in the ferrous foundry industry are used as shown in Table 3.2-7.

A cupola is a vertical, steel-shaft melting furnace, normally circular in cross-section. The cupola is the most important melting method in the iron foundry industry. It works on purchased scrap, pig iron, and home scrap. Coke and fluxes are the other important charge components.

An electric arc furnace is the most important melting device for steel foundaries and is an important one for iron foundries. It consists of a steel-encased refractory hearth on which materials can be melted by heat from electric arcs. Arc furnaces used in foundries vary in diameter from a few feet up to 15 feet. Arc furnaces normally operate on $100 \%$ scrap charge.

An induction furnace is a refractory-lined vessel in which the metal charge is melted by induction, i.e., by transforming electrical energy into heat. Induction furnaces are used in the melting of both iron and steel. Because induction furnaces are essentially melting and not refining furnaces they operate only on clean scrip. Induction furnaces are generally smaller than other types of melting furnaces and are either batch or semi-continuous operations. Induction furnaces are also used as holding furnaces.

A reverberatory air furnace is a rectangular or cylindrical stecl shell, refractory-lined throughout the inside, in which the heat source is above the shallow metal bath. It is used to a very limited extent only in malleable iron foundries.

The open-hearth furnace used in the foundry industry is similar to that used in steel mills. It varies in capacity from as little as 10 short tons to more than 200 short tons. The use of the openhearth is limited to a few plants in the steel foundry industry.

\subsubsection{Ferroalloys}

In 1976, ferroalloys were produced in the United States by electrolytic and metallothermic processes, in blast furnaces, and electric furnaces. One plant used the fused salt electrolytic process to produce low carbon ferromanganese.

\subsection{Blast Furnace}

The use of the blast furnace was limited to ferromanganese production. Two plants of this type, both owned by steel companies, were in operation in 1976. Neither is currently operating.

The ferromanganese blast furnace is of the same type used to produce pig iron. In fact, a furnace used to produce one of these products is sometimes converted to the other. However, the trend in the United States is from the blast furnace to the electric furnace due to technological and economic factors.

\subsection{Electric Furnace}

Roughly 100 electric furnaces are distributed among 38 ferroalloy plants. The submergedarc furnace, the most widely used electric type, accounts for more than $75 \%$ of all U.S. ferroalloy production. 


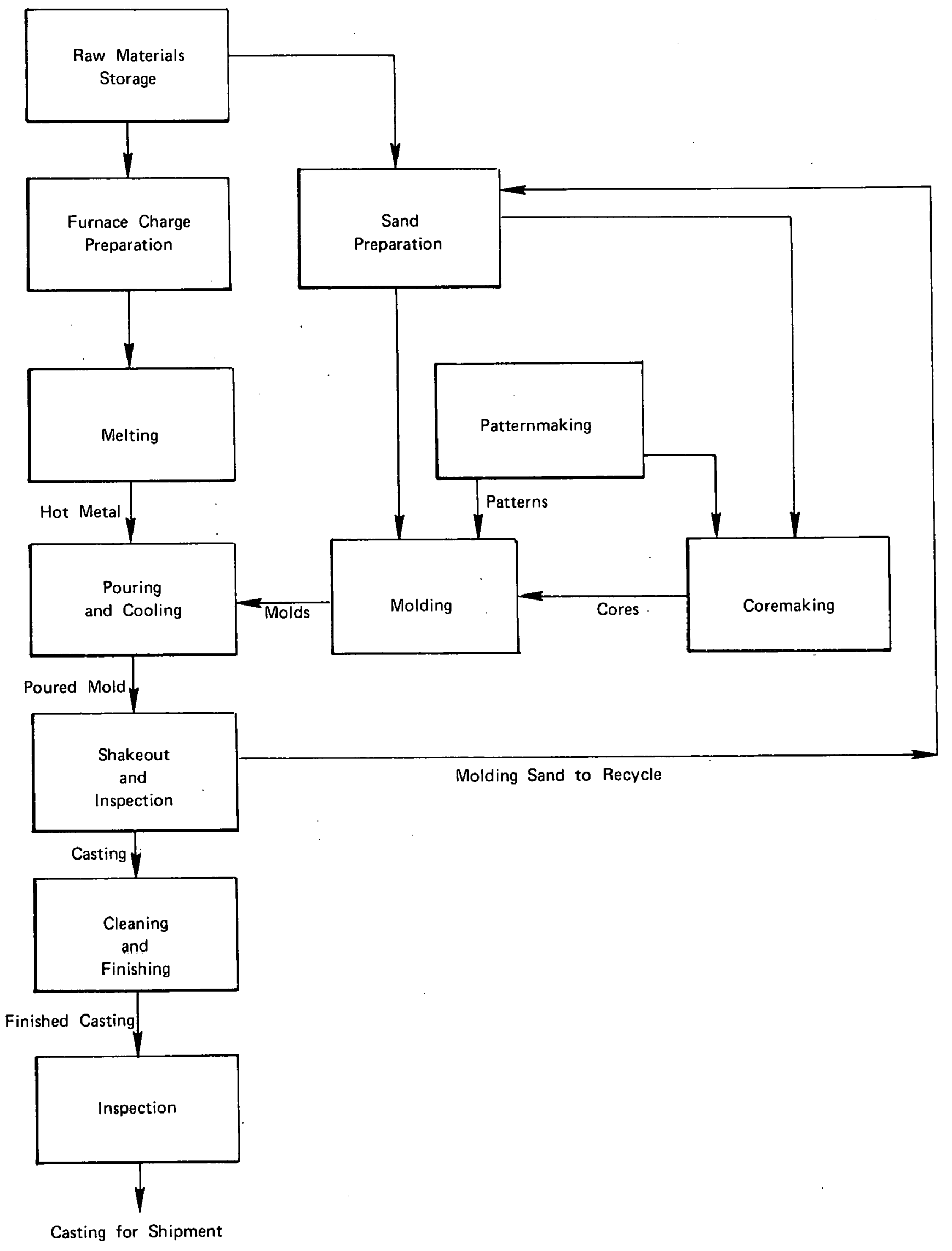

FIGURE 3.2-2 PROCESS FLOW DIAGRAM OF A TYPICAL FOUNDRY 
TABLE $3.2-7$

海LLTING METHODS USED IN FERROUS FOLINDRIES

Major Product

Melting Method

Cupola

Electric Arc Furnace

Coreless Induction

Air Furnace

Reverberatory

Open Hearth

Number of Foundries

In Major Product

Classification
Gray Ductile Malleable Total Iron Iron $\frac{\text { Iron }}{\text { Steel }}$ Ferrous Ind.

$73.3 \quad 36.4$

40.7

4.3

53.9

$8.5 \quad 10.2$

18.6

52.8

19.5

21.5

44.3

44.1

42.4

28.4

0.5

0.0

45.8

0.5

2.0

7.4

12.5

0.0

2.1

6.1

0.0

0.0

0.0

5.0

1.2

$1195 \quad 88$

59

422

1764

Source: Penton Publications Foundry Data Base Arthur D. Little, Inc., estimates 
The submerged-arc furnace is cylindrical, and may be as large as 50 feet in diameter. These furnaces require careful preparation of charge material. The charge could include ore, slag. forming materials such as lime, iron and steel borings and turnings, and coal or coke. Raw materials contain $10-20 \%$ free moisture and may be dried prior to charging.

Some ferroalloys, such as low-carbon ferromanganese and low-carbon ferrochromium, are produced using two submerged-arc electric furnaces or may be produced by other methods not necessarily involving liquid metal. The furnaces are arranged in such a way that the slags, which inevitably contain high concentrations of the expensive metal, are not wasted but are used as a feed material to a furnace producing a different grade of the same ferroalloy. Sequential submerged-arc furnaces or a combination of submerged-arc and open-arc furnace cycles may be used.

An example of a combination of a submerged-arc and a direct arc (or open-arc) furnace is shown in Figure 3.2-3. The direct arc furnace produces medium carbon ferromanganese $(82 \% \mathrm{Mn})$ and sends a manganese-rich slag to a submerged-arc furnace producing silicomanganese where the manganese units are recovered. Some of the silicomanganese, in turn, is sent to the furnace producing medium-carbon ferromanganese where it is used as a reducing agent. The remaining silicomanganese is sold. As a result, the discarded slag contains only about $6 \%$ manganese.

\subsubsection{Materials Flow}

\subsubsection{Iron and Steel}

In 1976, the United States iron and steel industry produced 128 million short tons of raw steel, $10 \%$ more than in 1975 but $12 \%$ less than in 1974 . Total shipments of all grades of steel products in 1976 equaled 89.4 million short tons. ${ }^{11}$ The flow of raw materials and intermediate products necessary in the production of this finished steel is briefly described in this section. Also included is a classification of recoverable material as pertains to the iron and steel industry as well as a general profile of the industry's recycling activities.

\subsection{General}

Figure 3.2-4, constructed from U.S. Bureau of Mines and AISI data in conjunction with Arthur D. Little Inc. estimates, gives a detailed flow of all materials within the iron and steel industry in 1976.

\subsection{Production of Pig Iron}

Domestic production of pig iron totaled 86.8 million short tons in 1976, an increase of 7 million short tons or $9 \%$ more than in 1975: Of this amount, about 82 million short tons were consumed by steelmaking processes. ${ }^{2,4}$

Raw materials to blast furnaces included pellets and sinter, flux, lump ore, coke and scrap. For every ton of pig iron produced in 1976, approximately 1.7 short tons of metalliferous materials were consumed in blast furnaces. Iron ore consumption, including agglomerates, totaled 136.8 million short tons. Sinter plants at or near the blast furnaces consumed 25.8 million short tons of iron ore in producing 36.4 million short tons of sinter. The remainder consisted of coke breeze, dusts and sludges, limestone and dolomite, cinder and slag, and scale. Domestic pellets charged equaled 69.5 million short tons and sinter sharged was 36.4 million short tons. Importod pellcto and sinter amounted to 17 million short tons. 


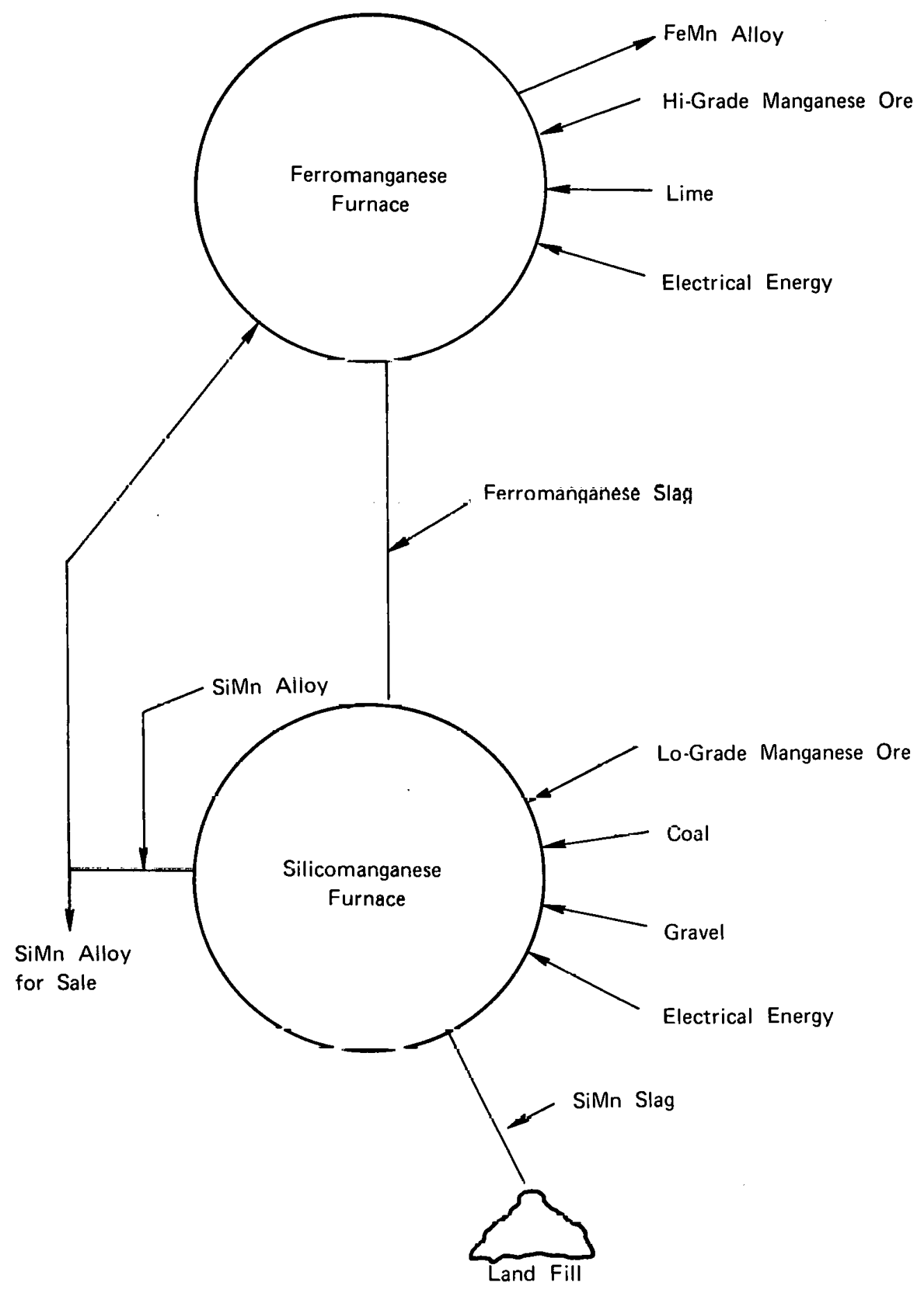

Source: Special Are Preprints, 32nd Clectric Гurnace Conference, AIME, 1974, p. 22

FIGURE 3.2-3 SCHEMATIC ILLUSTRATION OF AN INTEGRATED MANGANESE SMELTING AND REFINING FACILITY 

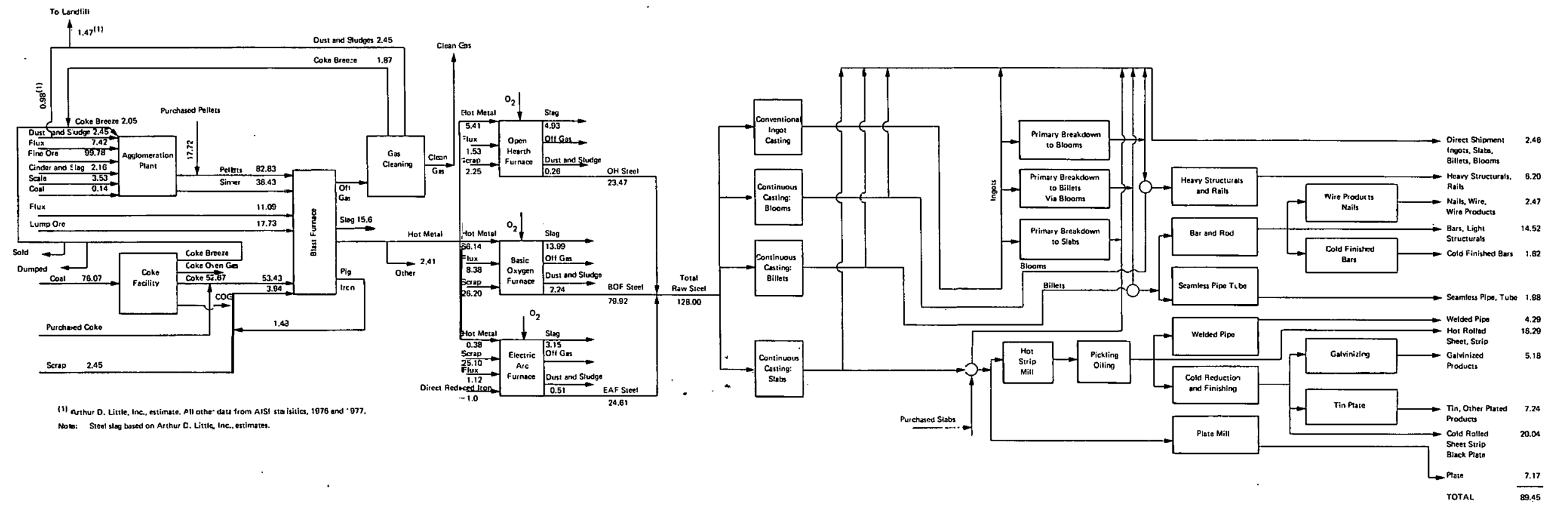

FIGURE 3.2-4 MATERIALS FLOW IN THE IRON AND STEEL INDUSTRY - 1976 All Datb in Millions of Tons 
Blank

$$
3-26
$$


Consumption of oxygen in blast furnaces totaled 26.9 billion cubic feet in 1976 compared with 25.9 billion cubic feet in 1975 . Through tuyere injection, blast furnaces consumed 9.7 billion cubic feet of coke oven gas; 445 million gallons of oil; 133 million gallons of tar, pitch, and miscellaneous fuels; and 157,671 short tons of bituminous coal. ${ }^{2,4}$

Besides pig iron, blast furnaces produce slag, dusts and sludges, and coke breeze. In 1976, approximately 15.6 million short tons of slag were produced, most of which were processed for the recovery of slag scrap prior to disposal in landfills. Pollution control equipment associated with blast furnace operations collected 2.4 million short tons of dusts and sludges and 1.9 million short tons of coke breeze.

\subsection{Production of Steel}

According to the American Iron and Steel Institute (AISI), production of raw steel in 1976 equaled almost $81 \%$ of industry capacity of 158 million short tons. This compares with a $76.2 \%$ utilization of 153 million short tons in 1975 . Of the total raw steel production, $62.8 \%$ was produced by the basic oxygen process, $18 \%$ by open hearth furnaces, and $19 \%$ by electric furnaces. The trend toward basic oxygen and electric furnaces and away from open hearths continued in 1976 .

Total shipments of steel products for 1976 equaled 89.4 million short tons, $12 \%$ more than in 1975. Shipments to the automotive industry totaled 21.4 million short tons, $40 \%$ higher than in 1975 , and shipments to service centers were up $15 \%$ to 14.6 million short tons. Shipments were down $15 \%$ and $8 \%$, respectively, to the oil and gas industries and to the construction market. ${ }^{11}$

Metalliferous materials charged to steel furnaces in 1976 averaged 1280 pounds of pig iron, 993 pounds of scrap, and 22 pounds of iron ore (including agglomerates) per short ton of steel produced. Nonmetallic materials charged to steelmaking furnaces in 1976 included 0.6 million short tons of fluorspar, 1.5 million short tons of limestone, 7.6 million short tons of lime and 1.3 million short tons of other fluxes. Oxygen consumption totaled 196.3 billion cubic feet compared with 178.4 billion cubic feet in 1975 .

AISI statistics indicated that open hearth furnaces consumed 15.4 million short tons of pig iron, 12.3 million short tons of scrap, 1.5 million short tons of fluxes, and 40.6 billion cubic feet of oxygen in 1976. Open hearth products included 23.5 million short tons of raw steel, about 4.9 million short tons of slag, and 0.3 million short tons of dusts and sludges. Basic oxygen furnaces consumed 66.1 million short tons of hot metal, 26.2 million short tons of scrap, 8.4 million short tons of fluxes and 149.2 billion cubic feet of oxygen to produce approximately 14.0 million short tons of slag, 79.9 million short tons of raw steel and 2.2 million short tons of dusts and sludges. Electric furnaces consumed 0.4 million short tons of pig iron, 25.1 million short tons of scrap, 1.1 million short tons of fluxes and 6.4 billion cubic feet of oxygen. Products included 24.6 million short tons of raw steel, 3.2 million short tons of slag and 0.5 million short tons of dusts and sludges.

According to AISI, steel melting furnaces in 1976 consumed 185.5 million gallons of fuel oil, 80.6 million gallons of tar and pitch, 52.8 billion cubic feet of natural gas and 5.3 billion cubic feet of coke oven gas. Total consumption of electric power by the iron and steel industry in 1976 equaled 54.3 billion kilowatt hours. 


\subsection{Classification of Recoverable Materials}

The materials containing iron units presently being recycled in the iron and steel industry fall into four categories: ferrous scrap, mill scale, dust and sludge, and slag.

\subsection{Ferrous Scrap}

Ferrous scrap is composed of three types of waste and scrap material. These are: home or revert scrap, prompt industrial scrap, and obsolete scrap. Collectively, prompt industrial and obsolete scrap are referred to as purchased scrap.

Home scrap is generated within the iron and steel industry as a result of melting, casting and processing operations. Most of it consists of ingot and bloom scrappings; billet, pipe and bar ends; hot metal spills and runnings; and plate shearing and sheet trimmings. Prompt industrial scrap is generated directly by metalworking firms in the fabrication of industrial and consumer products. It consists for the most part of clips, turnings, borings, punchings, stampings, trimmings and drillings. In contrast, obsolete scrap is generated by consumers of finished steel products. It is the processed form of ferrous waste resulting from discontinued economic use. This material is metallurgically very heterogeneous and can be contaminated with elements that are detrimental to steelmaking. Prompt industrial scrap is generally the preferred type of purchased scrap, depending on such factors as price, availahility and products being produced.

In 1976, the iron and steel industry consumed 68.4 million short tons of ferrous scrap. Consumption by grade of scrap for 1975 and 1976 is given in Table 3.2-8.

\subsection{Mill Scale}

Mill scale contains over $50 \%$ iron and is collected hy the water pollution control facilities associated with the following:

- Primary reduction mill

- Continuous casting

- Hot rolling mill

- Cold rolling mill

In addition to iron, these scales can contain small concentrations of trace metals, including chromium, copper, manganese, nickel, lead, and zinc. Mill scales can also contain as much $0.4 \%$ oil and grease. Because of the contained iron units, the scales are usually recycled to the sinter strand. Small amounts of scale are also recycled to the blast furnace via the agglomeration plant to steelmaking furnaces for recovery of iron and to promote lime or limestone dissolution.

\subsection{Dust and Sludge}

Dusts and sludges are the products in process gas cleaning and metal preparation as well as emission control devices associated with the major process steps in iron and steel industry. These materials are produced by coke plants, blast furnaces, steelmaking furnaces, and the various operaliuns in finishing mills.

Blast furnace dusts and sludges consist predominantly of iron oxides, carbon, silica, and lime. (They also contain traces of alkali components.) Dusts and sludges produced by the basic oxygen and open hearth furnaces contain iron oxide, lime, silicon, some lead and zinc, and small 
TABLE 3.2-8

CONSUMPTION OF FERROUS SCRAP BY GRADE

(Thousands of net tons)

$\underline{1975}$

$\underline{1976}$

Carbon Steel:

Low phosphorous plate \& punchings

733

987

Cut structurals \& plate

478

393

No. 1 heavy melting steel

22,205

23,984

No. 2 heavy melting steel

3,064

3,421

No. 1 \& electric furnace bundles

7,597

8,870

No. 2 \& all other bundles

2,324

2,584

Turnings \& borings

1,608

1,339

Slag scrap (Fe content)

4,082

4,180

Shredded or fragmentized

2,014

2,064

A11 other carbon steel scrap

11,711

12,933

TOTAL CARBON STEEL

55,816

60,755

Stainless Steel

687

1,020

Alloy steel (stainless)

1,869

1,829

Iron scrap

3,275

3,770

Other grades or types of scrap

1,189

1,053

TOTAL SCRAP

62,836

68,427

Source: Annual Statistical Report, American Iron and Steel Institute, 1976 and 1977. 
amounts of carbon. In order to recycle this fine material it must be agglomerated. The sinter plant is particularly suited for recycling these materials for the recovery of iron and carbon units.

In contrast, electric furnace dust and sludge is not recycled. These dusts and sludges contain significant amounts of lead and zinc, and occasionally other deleterious elements. In addition, sinter plants are usually not located near electric furnaces, thus precluding any simple "inhouse" recycle scheme. For both of these reasons, electric furnace dusts and sludges will probably not be recycled in the near future, and therefore these materials will not be considered in this study.

Sludges are also produced in various operations in steel milling facilities. Primary reduction mills, continuous casting units, hot rolling mills, cold rolling mills, tin plating mills, and galvanizing mills produce sludges as a result of water pollution control operations at a rate ranging from 0.1 to $10 \mathrm{~kg} / \mathrm{MT}$ of finished steel.

Because published data are not available on dusts and sludges, they are excluded from the target. analysis.

\subsection{Slag}

Slags are produced by blast, open hearth, electric arc, and basic oxygen furnaces. In varying amounts, all of these materials are recycled within the iron and steel industry. Blast furnace slag is not included in this study as a recoverable material, because it is usually sold to slag processors who recover by magnetic separation the iron units entrained in the slag. This material, known as slag scrap, is sold back to the iron and steel industry for processing. Such slag scrap is included in the category of ferrous scrap.

Open hearth and BOF slags are sometimes partially recycled to the sinter plant or used directly in the blast furnace. Reasons for this recycle include recovery of contained iron values. Lime values are also recovered to enhance sinter basicity. Electric furnace slag is recycled to a small extent, primarily to maintain a protective slag layer within the electric arc furnace during charging.

\subsection{Recycle Profile}

The U.S. iron and steel industry currently recycles substantial amounts of ferrous waste/scrap along with smaller amounts of slags, dusts and sludges, and scales. Unit operations to which these recyclable materials return include the sinter plant, the blast furnace, and all three types of steelmaking furnaces. In this section, the patterns of consumption of recyclable materials for each unit operation are described. Types of materials, quantities recycled, and technological reasons for their utilization are given. Thus a general recycle profile for the iron and steel industry is developed.

\subsection{Sinter Plants}

Materials currently being recycled to sinter plants include BOF and OHF slag, dust and sludge from the blast furnace, and mill scale. These materials are recycled both to recover iron units and fluxes, and to a small extent, to improve the basicity and binding characteristics of the sinter. In 1976, sinter plants consumed 2.2 million short tons of cinder and slag, 2.5 million short tons of dusts and sludges, and 3.5 million short tons of mill scale, according to AISI statistics. 


\subsection{Blast Furnace}

Materials recycled to blast furnaces include rolling mill scale, steelmaking slag, and ferrous scrap. In 1976, blast furnaces consumed 4.2 million short tons of mill cinder and roll scale, along with small amounts of various miscellaneous items. Net scrap consumption equaled 2.5 million short tons. About 1.5 million short tons of home scrap was also produced in 1976.

Roll scales - oxides that form on the surface of steel during heating for rolling - are recycled to blast furnaces to recover iron units that otherwise would be lost. This material is a source of relatively pure iron oxide, although in some mills it becomes contaminated with refractory and oily substances.

BOF slag contains about $25 \%$ iron oxide by weight, and an excess of bases over acids. It is recycled primarily to recover iron units and secondarily to replace a given amount of basic fluxes in the blast furnace burden. BOF slag also contains sufficient manganese to make it a useful source of this element. It is sometimes desirable to add BOF slag to blast furnace burdens in order to increase the manganese content where the hot metal is deficient and thereby prevent "slopping" in the BOF. The use of BOF slag is limited by the specification for the maximum phosphorus content of the hot metal produced. Furthermore, since its use increases the total quantity of slag per ton of hot metal, its use is limited by the blast furnace's slag capacity.

Ferrous scrap is recycled to blast furnaces both for the recovery of iron units and to increase the production of hot metal. This scrap is purchased or is produced by the blast furnace itself from slag processing or by subsequent operations within the plant complex.

\subsection{Basic Oxygen Furnaces}

In 1976, basic oxygen furnaces consumed 26.3 million short tons of ferrous scrap. The breakdown by type of scrap (home, purchased) is nol known. Scrap is recycled to basic oxygen furnaces primarily to recover iron units and secondarily to serve as a sink for thermal energy. On the average, basic oxygen charges consist of approximately $30 \%$ scrap, by weight.

In addition to scrap, mill scale is recycled to recover iron and to promote the dissolution of lime or limestone into the molten slag. A minor reason for recycling this material is to control furnace temperature by absorption of heat.

\subsection{Electric Arc Furnaces}

Recyclable materials consumed by electric furnaces include mill scale, electric furnace slag, and ferrous scrap. Mill scale is used to a limited (and undetermined) extent to lower the carbon content of the melt. Electric furnace slag is recycled to a small extent in order to maintain a protective slag layer within the furnaces to increase hearth life. Within the iron and steel industry, electric arc furnaces rank first in consumption of purchased scrap and second to BUF furnaces in the consumption of total (purchased and home) scrap. In 1976, electric arc furnaces consumed 25 million short tons of ferrous scrap versus only 0.4 million short tons of pig iron.

\subsection{Open Hearth Furnaces}

Recyclable materials consumed by open hearth furnaces in 1976 included 12.25 million short tons of ferrous scrap and much smaller quantities of open hearth slag and scale. 


\subsubsection{Ferrous Foundries}

\subsection{General}

The general materials flow in the ferrous foundry industries is shown in Figure 3.2-5.

\subsection{Classification of Recoverable Materials}

The major types of solid wastes generated in the iron and steel foundries are:

- Waste sand

- Core butts

- Dust and sludge

- Slag

- Floor sweepings

- Refractories

- Home scrap

The amounts of the above solid wastes generated in 1976 are shown in Table 3.2-9. The generation factors are estimated average values for all foundries in each of the three major foundry categnries.

\subsection{Recycling Profile}

Of the solid wastes generated in the ferrous foundry industries as given in Table 3.2-9, only home scrap and to a certain degree waste sand are recycled. The scrap is recycled almost entirely within the foundry where it is generated. Only very minor amounts of generated home scrap are sold back to the scrap industry (see Figure 3.2-5). The other types of solid wastes generated, which all contain various amounts of iron along with traces of heavy minerals that depend on type of foundry product, are not recycled at all because of technical/economic limitations.

\subsubsection{Ferroalloys}

\subsection{General}

\subsection{Ferrosilicon}

Feeds to the ferrosilicon furnace include quartzite, gravel, coal, coke, and ferrous scrap. Almost all the quartzite and gravel used is obtained from sources in the United States. Purchased ferrous scrap is consumed at a rate of 0.30 short tons per ton of ferrosilicon. Revert ferrous scrap is consumed at the rate of 0.30 short tons per ton of ferrosilicon. Revert ferrous scrap is consumed at the rate of 0.02 short tons per short ton of ferrosilicon.

Slag is not generated in the production of ferrosilicon. Particulates are emitted from furnaces at the rate of 0.45 short tons per short ton of $75 \%$ ferrosilicon and 0.23 short tons per short ton of $50 \%$ ferrosilicon. Recovery of particulates is about $90 \%$. The resulting dust is disposed of in open dumps.

\subsection{Ferrochromium}

Feeds to a ferrochromium furnace include chromium ore, quartzite, coal, coke, limestone and ferrous scrap. Very little ore is domestically produced. Major suppliers of chromite are South 

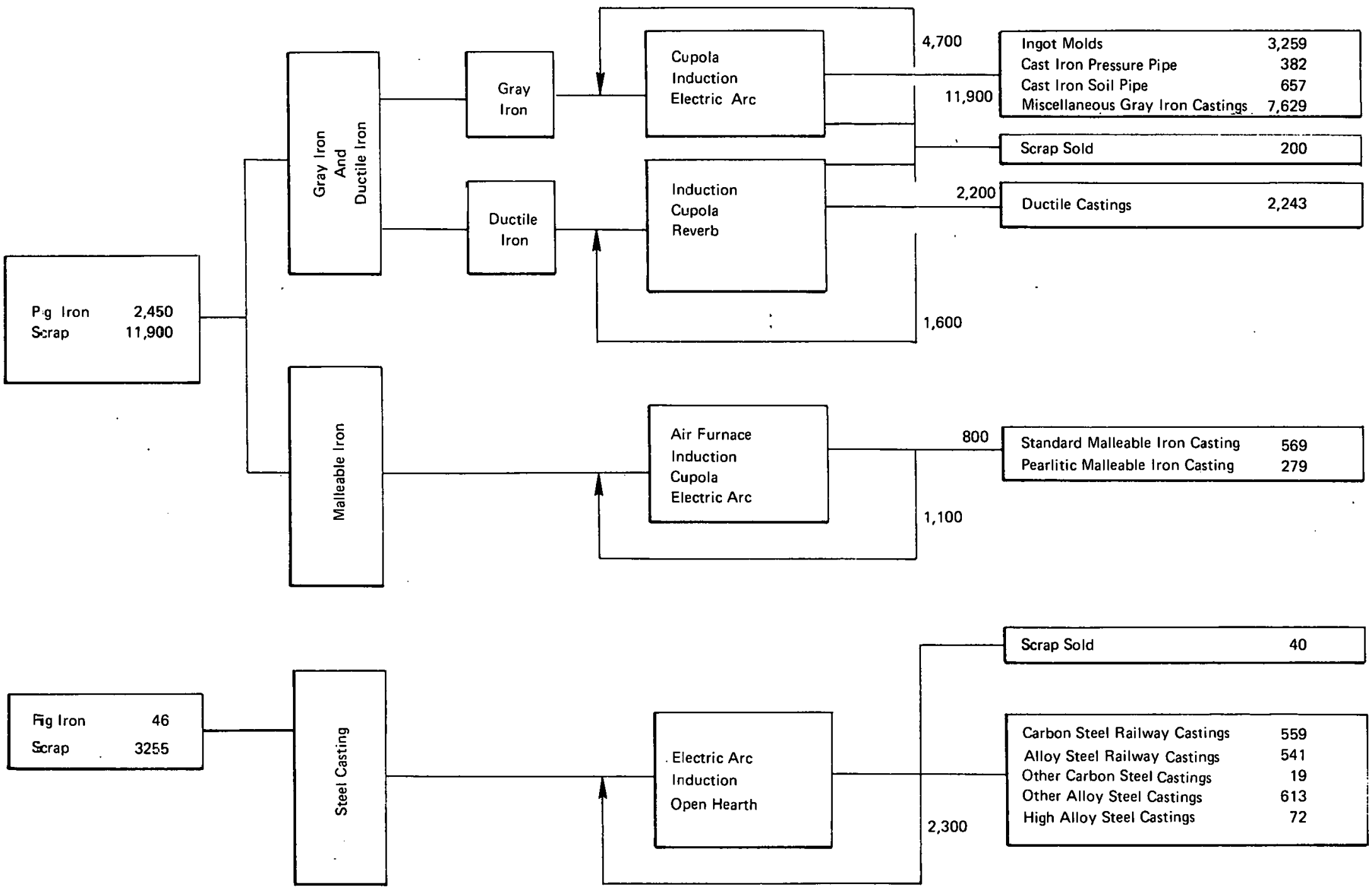
WASTE GENERATION FACTORS AND 1976 WASTE GENERATION - IRON AND STEEL FOUNDRIES

\begin{tabular}{|c|c|c|c|}
\hline Foundry & Type of Waste & $\begin{array}{l}\text { Generation }(1) \\
\text { Factor 1bs/ST of } \\
\text { Finished Castings } \\
\end{array}$ & $\begin{array}{c}1976 \\
\text { Waste Generation } \\
\text { Tons } \times 10^{3} \\
\end{array}$ \\
\hline \multirow{6}{*}{$\begin{array}{l}\text { Gray and Ductile } \\
\text { Iron }\end{array}$} & Slag & 125.9 & 888.0 \\
\hline & Sludgc & 65.6 & 403.0 \\
\hline & Dust & 131.3 & 926.0 \\
\hline & Sand & 1200.0 & 8460.0 \\
\hline & Refractories & 27.6 & 195.0 \\
\hline & Home Scrap (2) & & 6300.0 \\
\hline \multirow[t]{6}{*}{ Malleable Iron } & Slag & 111.1 & 47.0 \\
\hline & Sludge & 63.8 & 27.0 \\
\hline & Dust & 129.5 & 55.0 \\
\hline & Sand & 1200.0 & 510.0 \\
\hline & Refractories & 26.4 & 11.0 \\
\hline & Home Scrap (2) & & 1100.0 \\
\hline \multirow[t]{6}{*}{ Steel Castings } & Slag & 244.1 & 220.0 \\
\hline & Sludge & 72.8 & 66.0 \\
\hline & Dust & 372.0 & 335.0 \\
\hline & Sand & 1561.0 & 1405.0 \\
\hline & Refractories & 106.1 & 95.0 \\
\hline & Home Scrap (2) & & 2.300 .0 \\
\hline
\end{tabular}

Sources:

1. Assessment of Industrial Hazardous Waste Practices in the Metal Smelting and Refinery Industry, Volume III, No. ND-5520-M-1, Calspan.

2. "Iron and Steel Distribution in U.S.A.," Modern Casting, October 1977, p. 85. 
Africa, Turkey and the USSR. A typical high-carbon chromium plant consumes 0.053 short tons of ferrous scrap per short ton of ferrochromium.

By-products of ferrochromium production are particulates and slag. Approximately 0.17 short tons of particulates are entrained in furnace gas per ton of ferrochromium produced. If a dry removal system is used about 0.15 short tons of dust containing $0.34 \% \mathrm{Cr}$ are recovered per short ton of ferrochromium. If a wet collection system is used approximately 0.15 short tons of sludge are generated. It is estimated that between 1.5 and 2.0 short tons of slag are produced per short ton of ferrochromium. This slag is either open dumped or used in road building.

\subsection{Ferromanganese}

Most ferromanganese is produced in a plant containing two or three other furnaces. Silicomanganese is produced in the same plant in order to recover the manganese units from the ferromanganese slag and to serve as a reducing agent.

The furnace charge consists of manganese ore, coke, mill scale, remelted ferromanganese, and possibly scrap from outside the plant. At least one plant includes silicomanganese in the charge. Most, if not all, of the domestic ore consumed comes from shipments of government stockpile excesses. Ore from Africa, Australia, and Brazil accounted for $79 \%$ of the manganese units and $78 \%$ of the gross weight in 1976 .

Furnace products include ferromanganese, particulates, and slag. Slag, containing $53 \% \mathrm{Mn}$, is produced at the rate of 0.60 short ton per short ton of ferromanganese. This slag can be charged to silicomanganese furnaces if the plant is integrated with silicomanganese production. About 0.36 short ton of ferromanganese slag per short ton FeMn produced is charged to silicomanganese furnaces. The remaining slag is stored for possible use in future silicomanganese production. Particulates in gaseous emissions are produced at the rate of 0.17 short ton per short ton of ferromanganese. Most of this material is disposed of by dumping.

\subsection{Silicomanganese}

Of the nine plants producing silicomanganese, eight were combined with ferromanganese furnaces. The charge to silicomanganese furnaces contains ferromanganese slag, manganese ore, coal, coke, dolomite, quartz, mill scale, and remelts. Ferromanganese slag is consumed at the rate of 1.34 ton per ton of silicomanganese leaving the plant.

Furnace byproducts include slag and particulates. Slag is produced at the rate of 1.10 ton per ton of silicomanganese. Approximately 0.79 ton of this is used for road base and 0.32 ton is transported to open dumps.

\subsection{Classification of Recoverable Material}

Sources of recoverable materials in the ferroalloy industry are slag, dust and sludge, and ferrous scrap.

\subsection{Recycle Profile}

Figure 3.2-6 shows the paths taken by recyclable materials. Flow rates in 1976 are given in Table 3.2-10. Of major significance is the flow of manganese units in ferromanganese slag to the silicomanganese furnace. 


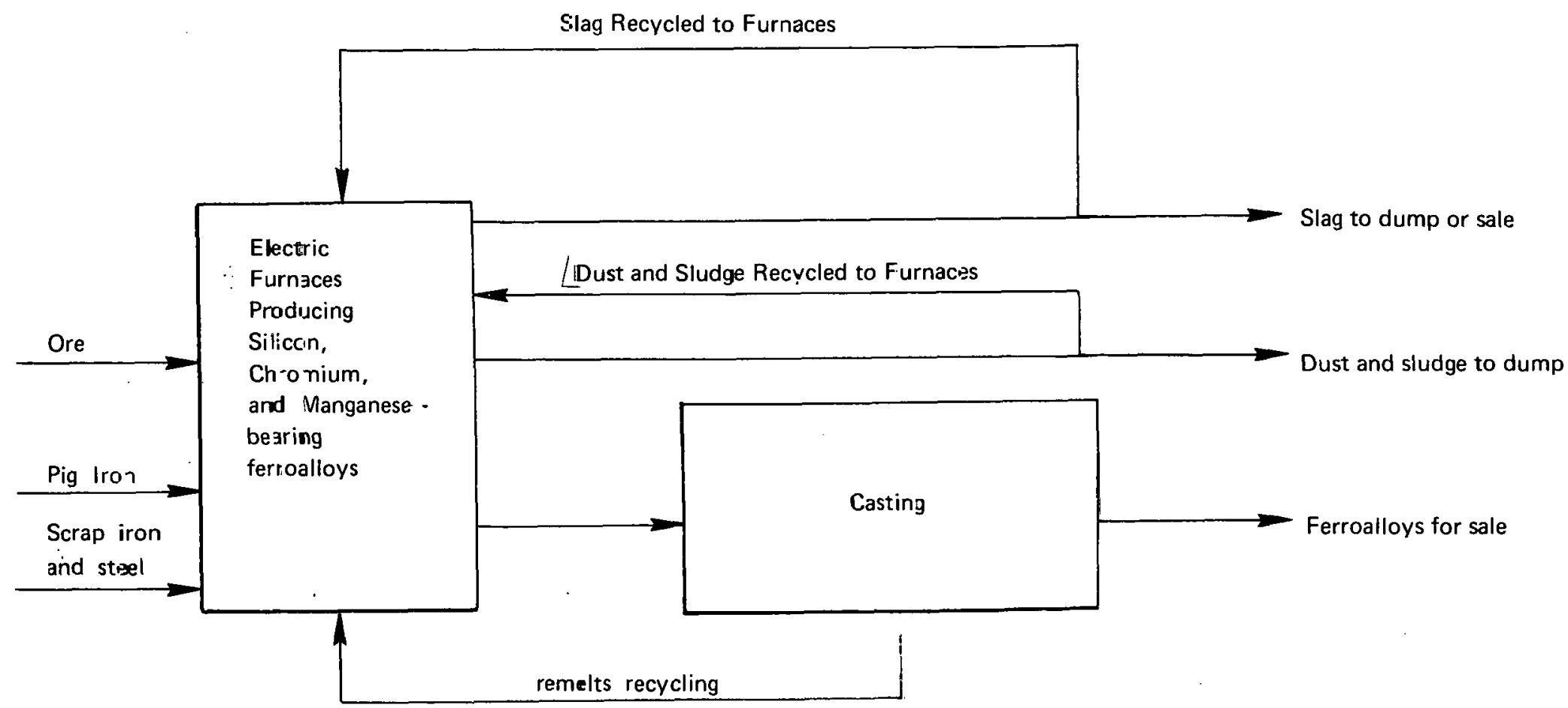

Source: Arthur D. Litt e, Inc.

FIGURE 3.2-6 FIOW DIAGRAM IN THE FERROALLOYS INCUSTRY 
TABLE $3.2-10$

MATERIALS FLOW - 1976

FERROALLOYS SEGMENT

(Gross Weight, Short Tons)

Material

Ferroalloy Production

ore

Pig Iron

Slag - produced by electric furnaces

Slag - recycled to furnaces

Slag - stored for possible future use

Slag - dumped

Slag - used in road building

Dust and STudge

\begin{tabular}{c} 
Ferrosilicon \\
\hline 860,799 \\
NA \\
NA \\
0 \\
0 \\
0 \\
0 \\
0
\end{tabular}

290,950

$\frac{\text { Ferrochromium }}{269,247}$

597,000

NA

471,182

NA

NA

NA

NA

45,233
Ferromanganese

482,662

$1,260,000$

NA

NA

289,597

173,758

$N A$

115,839

NA

NA

40,609

NA

101,200

SOURCES: U.S. Eureau of Mines Minerals Yearbook, 1976.

Calspan, "Assessment of Industrial Hazardous Waste Practices in Metal Smelting and Refining Industry, "Volume III, 1977. 


\subsubsection{Future Trends}

\subsubsection{Iron and Steel}

During 1976, the U.S. iron and steel industry operated plants with an effective capacity utilization of $80.9 \%$ and produced 128.0 million short tons of raw steel. Assuming that U.S. raw steel production will grow at $1.5-2.0 \%$ per year, raw steel output would be about 174 million short tons by 1987. Final product shipments would be in the neighborhood of 125 million short tons. ${ }^{1}$

The most significant trend within the U.S. iron and steel industry is the shift in the mix of the three principal steelmaking furnaces, i.e., basic oxygen, open hearth, and electric arc: The percent of total steel output for each of these furnaces for the years 1952-1976 is given in Table 3.2-11. Most of the BOF capacity came on-stream in the 1963-1970 period. The rate of BOF installation has since declined substantially, but, by $1 y^{\prime} / 6, B O F ' s$ accounted for approximately $62 \%$ of U.S. raw steel production. This percentage is expected to increase by 1987 .

Most of the BOF growth has been achieved at the expense of the open heartl process, whose contribution to total domestic steel production has declined from 105.4 million short tons in 1955 (90\%) to 23.5 million short tons in $1976(18.3 \%)$. The significant attrition in the number of open hearth shops over the past few years is primarily the result of economic competition from the hasic oxygen process, and of the pressure brought on the industry by environmental regulations.

A second inportant trend which has taken place is the profileration of electric furnace "mini-mills" in areas outside the traditional steelmaking centers. This growth in capacity in recent years and plans for further growth have been spurred on by a number of technological, market, and economic considerations including availability of continous casting, the application of ultra high power in arc-furnace technology, the increased scrap availability caused by the simultaneous growth in basic oxygen steelmaking and decline in open hearth capacity, and significantly smaller capital outlays required for this type of installation versus BOF steelmaking. In addition, small semi-integrated shops are able to take advantage of at least two other facturs, both related to transportation costs: (1) lucal scrap generally custs less than that in the major. steelmaking districts, and (2) costs of delivery to local markets are often lower than the cust of shipping steel from the major steelmaking centers. According to industry sources over the next decade electric arc installations may increase their share of raw steel production from the present value of $23 \%$ to over $30 \%$.

Another significant factor in the iron and steel industry is the acceptance of continuous casting for high volume production. It is likely that musl new U.S. steel plants geared to produce billets and slabs products will install continuous casting in the foreseeable future. Continuous casting capacity has increased sixfold in the period from 1969 to $1977 .{ }^{13}$ By the end of 1978,31 million short tons of capacity will be installed in 66 sleel plants in the United States. The principal reasons of this increased capacity are: (1) higher yields with impruved quality and uniformity, an important factor in reducing costs, (2) lower man-hour requirements, and most importantly, (3) significantly reduced energy requirements.

\subsubsection{Ferrous Foundries}

\subsection{Iron Castings}

Historical production levels for iron castings, 1955-1976, are shown in Table 3.2-12. Gray iron production normally consists of approximately $40 \%$ ingot molds, stools, pipe, and mill rolls, 
TABLE 3.2-11

RAW STEEL PRODUCTION BY PROCESS - 1952-1976

\begin{tabular}{|c|c|c|c|c|c|c|c|c|c|}
\hline \multirow[b]{2}{*}{ Year } & \multicolumn{2}{|c|}{ Open Hearth } & \multicolumn{2}{|c|}{ Basic Oxygen } & \multicolumn{2}{|c|}{ Bessemer } & \multicolumn{2}{|c|}{ Electric } & \multirow{2}{*}{$\begin{array}{l}\text { Total } \\
\text { Thousands } \\
\text { Net Tons }\end{array}$} \\
\hline & $\begin{array}{l}\text { Thousands } \\
\text { Net Tons }\end{array}$ & $\underline{\%}$ & $\begin{array}{l}\text { Thousands } \\
\text { Net Tons }\end{array}$ & $\underline{\%}$ & $\begin{array}{l}\text { Thousands } \\
\text { Net Tons }\end{array}$ & $\underline{\%}$ & $\begin{array}{l}\text { Thousands } \\
\text { Net Tons }\end{array}$ & $\underline{\%}$ & \\
\hline 1952 & 82,846 & 88.9 & - & - & 3,524 & 3.8 & 6,798 & 7.3 & 93,168 \\
\hline 1953 & 100,474 & 90.0 & - & - & 3,856 & 3.5 & 7,280 & 6.5 & 111,610 \\
\hline 1954 & 80,328 & 91.0 & - & - & 2,548 & 2.9 & 5,436 & 6.1 & 88,312 \\
\hline 1955 & 105,359 & 90.0 & 307 & .3 & 3,320 & 2.8 & 8,050 & 7.2 & $117 ; 036$ \\
\hline 1956 & 102,841 & 89.2 & 506 & .4 & 3,228 & 2.8 & 8,641 & 8.0 & 115,216 \\
\hline 1957 & 101,658 & 90.2 & 611 & .5 & 2,475 & 2.2 & 7,971 & 7.6 & 112,715 \\
\hline 1958 & 75,880 & 89.0 & 1,323 & 1.5 & 1,396 & 1.6 & 6,656 & 7.9 & 86,255 \\
\hline 1959 & 81,669 & 87.3 & 1,864 & 2.0 & 1,380 & 1.5 & 8,533 & 9.2 & 93,446 \\
\hline 1960 & 86.368 & 87.0 & 3,346 & 3.3 & 1,189 & 1.5 & 8,379 & 9.2 & 99,282 \\
\hline 196.1 & 84.502 & 86.2 & 3,967 & 4.0 & 881 & .9 & 8,664 & 8.9 & 98,014 \\
\hline 196.2 & 82.957 & 84.8 & 5,553 & 5.2 & 805 & .8 & 9,013 & 9.2 & 98,328 \\
\hline 196.3 & 88,834 & 81.3 & 8,544 & 7.8 & 963 & .9 & 10,920 & 10.0 & 109,261 \\
\hline 1964 & 98,098 & 77.2 & 15,442 & 12.2 & 858 & .6 & 12,678 & 10.0 & 127,076 \\
\hline 1965 & 94.193 & 71.7 & 22,879 & 17.4 & 586 & .4 & 13,804 & 10.5 & 131,462 \\
\hline $19 E 6$ & 85,025 & 63.4 & 33,928 & 25.4 & 278 & .2 & 14,870 & 11.0 & 134,101 \\
\hline 1967 & 70.690 & 55.6 & 47,434 & 32.5 & * & * & 15,089 & 11.9 & 127,213 \\
\hline $19 \in 8$ & $65: 836$ & 50.1 & 48,812 & 37.2 & * & * & 16,814 & 12.7 & 131,462 \\
\hline 1969 & 60.894 & 43.1 & 50,236 & 42.6 & - & - & 20,132 & 14.2 & 141,262 \\
\hline 1970 & $48: 022$ & 36.6 & 53,330 & 48.2 & - & - & 20,162 & 15.2 & 131,514 \\
\hline 1971 & 35,559 & 29.5 & 53,943 & 53.1 & - & - & 20,941 & 17.4 & 120,443 \\
\hline 1972 & 34,936 & 26.2 & 74,584 & 56.0 & - & - & 23,721 & 17.8 & 133,241 \\
\hline 1973 & 39,780 & 26.4 & 83,260 & 55.2 & - & - & 27,759 & 18.4 & 150,799 \\
\hline 1974 & 35,499 & 24.3 & 81,552 & 56.0 & - & - & 28,669 & 19.7 & 145,720 \\
\hline 1975 & 22,161 & 19.1 & $? 1,801$ & 61.5 & - & - & 22,680 & 19.4 & 116,642 \\
\hline 1976 & 23,470 & 18.3 & 79,918 & 62.4 & - & - & 24,612 & 19.3 & 128,000 \\
\hline
\end{tabular}

Source: Annual Statistical Reports, American Iron and Steel Institute, 1952-1976. 
TABLE 3.2-12

\section{PRODUCTION OF IRON CASTINGS - 1955-1976}

(thous and net tons)

\begin{tabular}{|c|c|c|c|}
\hline Year & $\begin{array}{c}\text { Gray and Ductile } \\
\text { Castings }\end{array}$ & $\begin{array}{l}\text { Malleable } \\
\text { Castings } \\
\end{array}$ & Tntal \\
\hline $\begin{array}{l}1955 \\
1956 \\
1957 \\
1958 \\
1959 \\
1960 \\
1961 \\
1962 \\
1963 \\
1964 \\
1965 \\
1966 \\
1967 \\
1968 \\
1969 \\
1970 \\
1911 \\
1972 \\
1973 \\
1974 \\
1975 \\
1976\end{array}$ & $\begin{array}{l}14,838 \\
13,861 \\
12,665 \\
10,358 \\
12,308 \\
11,594 \\
10,824 \\
11,553 \\
12,764 \\
14,316 \\
15,713 \\
15,716 \\
14,329 \\
15,130 \\
15,433 \\
13,945 \\
14,016 \\
15,217 \\
16,958 \\
15,660 \\
12,448 \\
14,140\end{array}$ & $\begin{array}{r}1105 \\
952 \\
863 \\
661 \\
916 \\
821 \\
723 \\
868 \\
933 \\
1001 \\
1136 \\
1131 \\
1041 \\
1007 \\
1172 \\
852 \\
887 \\
960 \\
1030 \\
912 \\
729 \\
848\end{array}$ & $\begin{array}{l}15,843 \\
14,813 \\
13,528 \\
11,019 \\
13,224 \\
12,415 \\
11,547 \\
12,421 \\
13,697 \\
15,317 \\
16,849 \\
16,847 \\
15,370 \\
16,137 \\
17,105 \\
14,797 \\
14,898 \\
16,177 \\
17,988 \\
16,572 \\
13,177 \\
14,988\end{array}$ \\
\hline
\end{tabular}

Source: U.S. Department of Commerce, Bureau of Census, Current Industrial Reports, M33, 1955-1976. 
with the remaining $60 \%$ miscellaneous industrial gray iron. The three largest gray iron markets are automotive, farm machinery and engines. Use of gray iron has been limited by:

- Weight reduction of automotive engine blocks

- Size reduction of air conditioner compressors

- Material substitution - aluminum, ductile iron, and plastics

- Increased production of smaller compact cars

The major market for ductile iron is pressure pipe, followed by motor vehicles, engines, and farm machinery. Ductile iron has had an historical growth rate of $10-12 \%$, giving it the best record in the ferrous foundry industry. ${ }^{6}$

Projected growth is mainly based on the following areas:

- replacement of other ferrous castings, primarily malleable iron, and steel.

- replacement of forgings, such as automobile crankshafts.

Seventy-five percent of available malleable iron is consumed by the automotive industry. Other markets are valves, pipe fittings, construction machinery, farm machinery, and railroad equipment.

According to Arthur D. Little, Inc., estimates, the production of iron castings in 1987 is estimated at approximately 20 million short tons.

\subsection{Steel Castings}

Steel casting production is basically determined by the consumption in the railroad and capital goods industries. Capital goods markets for steel castings are construction machinery, mining machinery, material hauling equipment, and metal working equipment.

Table 3.2-13 gives the historical production levels of steel castings. The share of total production accounted for by the various types of steel castings is projected to shift fairly substantially. Alloy steel castings will increase their share of production at the expense of other carbon steel castings. According to Arthur D. Little, Inc., estimates steel castings production in 1987 is projected at 2 million short tons.

\subsubsection{Ferroalloys}

Consumption of ferroalloys is determined by the production of steel and cast iron. Of the total ferrosilicon consumed, $53 \%$ was used in cast irons, $17 \%$ in carbon steel, and $15 \%$ in the remaining types of steel. Of the total chromium in ferrochromium consumed, $68 \%$ was used in stainless and heat-resisting steel, and $20 \%$ in other types of steel. Of the ferromanganese consumed $77 \%$ was used in carbon steel and $17 \%$ in the remaining types of steel. Of the silicomanganese consumed, $57 \%$ was used in carbon steel, and $30 \%$ in other types of steel. Annual ferroalloy production over the last 10 years is shown in Table 3.2-14.

Future growth patterns of the major ferroalloys will be linked to the iron and steel growth projections and to the level of imports. 
TABLE $3.2-13$

PRODUCTION OF STEEL CASTINGS - 1955-1976

(thousand net tons)

$\begin{array}{cc}\text { Year } & \begin{array}{c}\text { Stee1 } \\ \text { Castings }\end{array} \\ 1955 & 1531 \\ 1956 & 1932 \\ 1957 & 1766 \\ 1958 & 1121 \\ 1959 & 1413 \\ 1960 & 1392 \\ 1961 & 1217 \\ 1962 & 1423 \\ 1963 & 1504 \\ 1964 & 1835 \\ 1965 & 1961 \\ 1966 & 2156 \\ 1967 & 1857 \\ 1968 & 1730 \\ 1969 & 1897 \\ 1970 & 1724 \\ 1971 & 1589 \\ 1972 & 1610 \\ 1973 & 1897 \\ 1974 & 2091 \\ 1975 & 1937 \\ 1976 & 1955\end{array}$

Source: U.S. Department of Commerce, Bureau of Census, current industrial reports, M33, 1955-1976. 
TABLE 3.2-14

FERROALLOYS PRODUCED AND SHIPPED - 1967-1976

\begin{tabular}{|c|c|c|c|c|c|c|c|c|c|}
\hline Year & $\begin{array}{l}\text { Production of } \\
\text { Ferrosilocon } \\
\text { (gross weight) } \\
\text { (short tons) } \\
\end{array}$ & $\begin{array}{c}\text { A1 loy El ement } \\
\text { Contained } \\
\text { (average percent) }\end{array}$ & $\begin{array}{l}\text { Production of } \\
\text { Ferromanganese } \\
\text { (:oss weight) } \\
\text { (short tons) } \\
\end{array}$ & $\begin{array}{c}\text { Al loy Element } \\
\text { Conta ined } \\
\text { (average percent) }\end{array}$ & $\begin{array}{l}\text { Production of } \\
\text { Chromium Al loys } \\
\text { (gross weight) } \\
\text { (short tons) } \\
\end{array}$ & $\begin{array}{c}\text { Alloy Element } \\
\text { Contained } \\
\text { (average percent) }\end{array}$ & $\begin{array}{l}\text { Product ion of } \\
\text { Sil ico Manganese } \\
\text { (gross weight) } \\
\text { (short tons) } \\
\end{array}$ & (average percent) & $\begin{array}{c}\text { Total Ferroalloy } \\
\text { Product ion } \\
\text { (gross weight) } \\
\text { (short tons) } \\
\end{array}$ \\
\hline 1976 & 860,799 & 57.0 & 482,662 & 79.0 & 269,247 & 60.0 & 128,917 & 66.0 & $1,910,218$ \\
\hline 1975 & 790,860 & 55.0 & 575,809 & 79.0 & 248,817 & 59.0 & 143,262 & 66.0 & $1,926,454$ \\
\hline 1974 & 905,274 & .56 .8 & 544,361 & 78.0 & 440,660 & 60.3 & 196,140 & 65.2 & $2,283,501$ \\
\hline 1973 & $1,012,807$ & 53.2 & 683,075 & 78.8 & 426,846 & 60.8 & 183,702 & 66.3 & $2,519,955$ \\
\hline 1972 & 841,386 & 59.8 & 800,723 & 78.3 & 352,305 & 62.0 & 153,234 & 65.3 & $2,526,624$ \\
\hline 1971 & 687,166 & 64.2 & 759,896 & 78.6 & 355,658 & 61.0 & 164,682 & 66.0 & $2,331,055$ \\
\hline$i 970$ & 709,287 & 59.2 & 835,463 & 78.5 & 405,776 & 63.2 & 193,219 & 66.0 & $2,595,188$ \\
\hline 1969 & 715,172 & 57.8 & 852,019 & 77.3 & 419,038 & 62.2 & 222,877 & 66.0 & $2,628,503$ \\
\hline 1968 & 665,383 & 56.6 & 879,962 & 78.0 & 389,572 & 62.6 & 284,499 & 66.0 & $2,621,061$ \\
\hline 1967 & 673,535 & 56.6 & 940,927 & 78.2 & 446,137 & 60.7 & 245,798 & 65.9 & $2,749,505$ \\
\hline
\end{tabular}

Source: U.S. Bureau of Mines, Mirerals Yearbook, 1976. 


\subsection{ALUMINUM}

\subsubsection{Industry Definition}

The aluminum industry comprises the following components based on SIC classification: ${ }^{(2)}$

- SIC 3334 - Primary Production of Aluminum includes establishments primarily engaged in producing aluminum from alumina. The products from these establishments are:

- Aluminum ingot and/or molten metal: primary

- Extrusion ingot, aluminum: primary

- The part of SIC 3341 -- Sccondary Smelting and Refining of Nonferrous Melals that are involved in the production of aluminum and aluminum base allops from scrap or dross. It comprises establishments primarily engyger in recnvering aluminum metal and aluminum-base alloys from new and old scrap and dross. 'The products/activities (aluminum related) of these estahlishments are:

- Aluminum extrusion ingot: secondary

- Aluminum ingot and/or molten metal: secondary

- Aluminum notched bar/shot for dioxidation.

- SIC 3353 - Aluminum Sheet, Plate and Foil include establishments primarily engaged in flat rolling aluminum and aluminum-based alloy basic shapes such as sheet, plate, and foil, including establishments producing welded tube. Also included are establishments primarily producing similar products by continuous casting. The products from these establishments are as follows:

.. Coilcd, sheet: aluminum

- Foil, plain: aluminum

- Plate: aluminum

- Sheet: aluminum

- Tube, welded: aluminum

- SIC 3354 - Aluminum Extruded Products include establishments primarily engaged in cxtruding aluminum and aluminum-based alloy basic shapes such as rod and bar, pipc and tube, and tube bloons, including eslablishments producing tube by drawing. The products from these establishments are:

- Bar, aluminum: extruded

-..- Extruded shapes: aluminum

- Pipe, aluminum: cxtruded

- Rod, aluminum: extruded

- Tube, aluminum: extruded or drawn

- Tube blooms, aluminum: extruded

- SIC 3355 - Aluminum Rolling and Drawing, Not Elsewhere Classified includes establishments primarily engaged in rolling, drawing, and other operations resulting in the production of aluminum ingot, including extrusion ingot, and aluminum 
and aluminum-based alloy basic shapes, not elsewhere classified, such as rolled and continuous cast rod and bar. The products from these establishments are:

- Bar, aluminum: rolled

- Rod, aluminum: continuous cast

- Ingot, aluminum: made in rolling mills

- Rod, aluminum: rolled

- Rod, aluminum: continuous cast

- Slugs, aluminum

- Structural shapes: rolled aluminum

- Wire, aluminum: made in rolling mills

- A part of SIC 3357 - Drawing and Insulating of Nonferrous Wire that Produces Aluminum Based Wire includes establishments primarily engaged in drawing, drawing and insulating, and insulating wire and cable of aluminum from purchased wire bar, rod, or wire. The products from these establishments are: (aluminum based only)

- Automotive and aircraft wire and cable, aluminum

- Cable, aluminum: bare, or reinforced, conductor

- Coaxial cable

- Communications wire and cable

- Shipboard cable

- Signal and control cable

- Weatherproof wire and cable

- Wire, insulated, or covered (mec)

- SIC 3361 - Aluminum Foundries (Castings) includes establishments primarily engaged in manufacturing sand, permanent mold, and die castings of aluminum and aluminum-based alloys.

- A part of SIC 3399 - Primary Metal Products Not Elsewhere Classified includes establishments primarily engaged in the production of aluminum nails, brads, spikes, powder, flake and paste.

In addition, bauxite mining (SIC 1051) and bauxite refining (SIC 2819) provide the alumina for primary aluminum production. Similarly, activities for manufacturing aluminum products are included in SIC 34, e.g., part of SIC 3463 deals with aluminum forgings.

\subsubsection{Industry Structure}

The aluminum industry can be divided into four segments:

- Primary Aluminum (SIC 3334)

- Secondary Aluminum (SIC 3341 - Aluminum-related sector only)

- Aluminum Foundries (SIC 3361)

- Others (SIC 3353, 3354, 3555, 3357, 3361, 3399, and 3463) 
The primary, secondary and foundry segments of the aluminum industry are described briefly in this section. The establishments engaged in other activities covered by the industry are so numerous and diverse that it is extremely difficult to characterize them. Because the primary, secondary and foundry generate aluminum scrap that is sent to primary, secondary smelters or to foundries for recovery, it is more appropriate to understand the industry structure related to these three segments. Some fabricators having melting facilities are also able to use aluminum scrap in their operations. The aluminum production process and the inter-relations among the four segments of the aluminum industry are shown schematically in Figure 3.3-1.

\subsubsection{Primary Aluminum Industry}

The most important activities carried out by the industry are:

- Production of alumina from bauxite by the Bayer process

- Reduction of alumina to aluminum metal by the Hall-Heroult electrolytic reduction proces3.

These two activities are carried out at entirely separate locations (Figure 3.3-2).

Within the United States there are nine alumina production plants, with a total capacity eslimated to be equivalent to 4 million short tons/year of aluminum (or approximately 7.7 million short tons/year of alumina) in 1976. The breakdown by companies and their plants is shown in Table 3.3-1. There are 32 aluminum reduction plants in the United States, operated by 12 companies, five of which are also alumina producers. The total aluminum production capacity is estimated at 5 million short tons/year for 1976. The details are shown in Table 3.3-2.

The 12 domestic firms are of unequal size and are multiplant, vertically integrated corpü rations. The three largest domestic companies (Alcoa, Reynolds, and Kaiser) accounted for $65 \%$ of domestic primary aluminum capacity in 1976. Aluminum Company of Canada, Ltd., via its U.S. subsidiary, Alcan Aluminum Corporation, is the fourth largest U.S. aluminum fabricator and an important seller of primary ingot in the country. ${ }^{(1)}$ Consequently, Alcan, even though it does not have a primary smelter in the United States, plays a significant role in domestic aluminum shipments.

\subsubsection{Secondary Aluminum Industry}

The secondary alumlnum industry comprises:

- Producers of alloy ingot and hot metal for foundries and die casters and bar and shot for steel deoxidation, and

- Produrers of secondary extruaion ingnta for exliusiun planta.

Most firms in the secondary aluminum industry have one plant and are either family-owned or owned by small corporations. The minority of firms, which represent a large portion of the production, however, are either large corporations, or subsidiaries of large corporations and are generally multiplant operations. The integration level of these firms is low, with the exception of extrusion ingot manufacturers who produce extruded products such as siding, doors, and windows. With the exception of those firms owned by conglomerates, the level of diversification of most of the companies involved in secondary aluminum smelting is low. In 1972,the four largest secondary aluminum companies accounted for 50 and $80 \%$ of the value of secondary ingot and extrusion ingot shipments, respectively. ${ }^{(2)}$ 


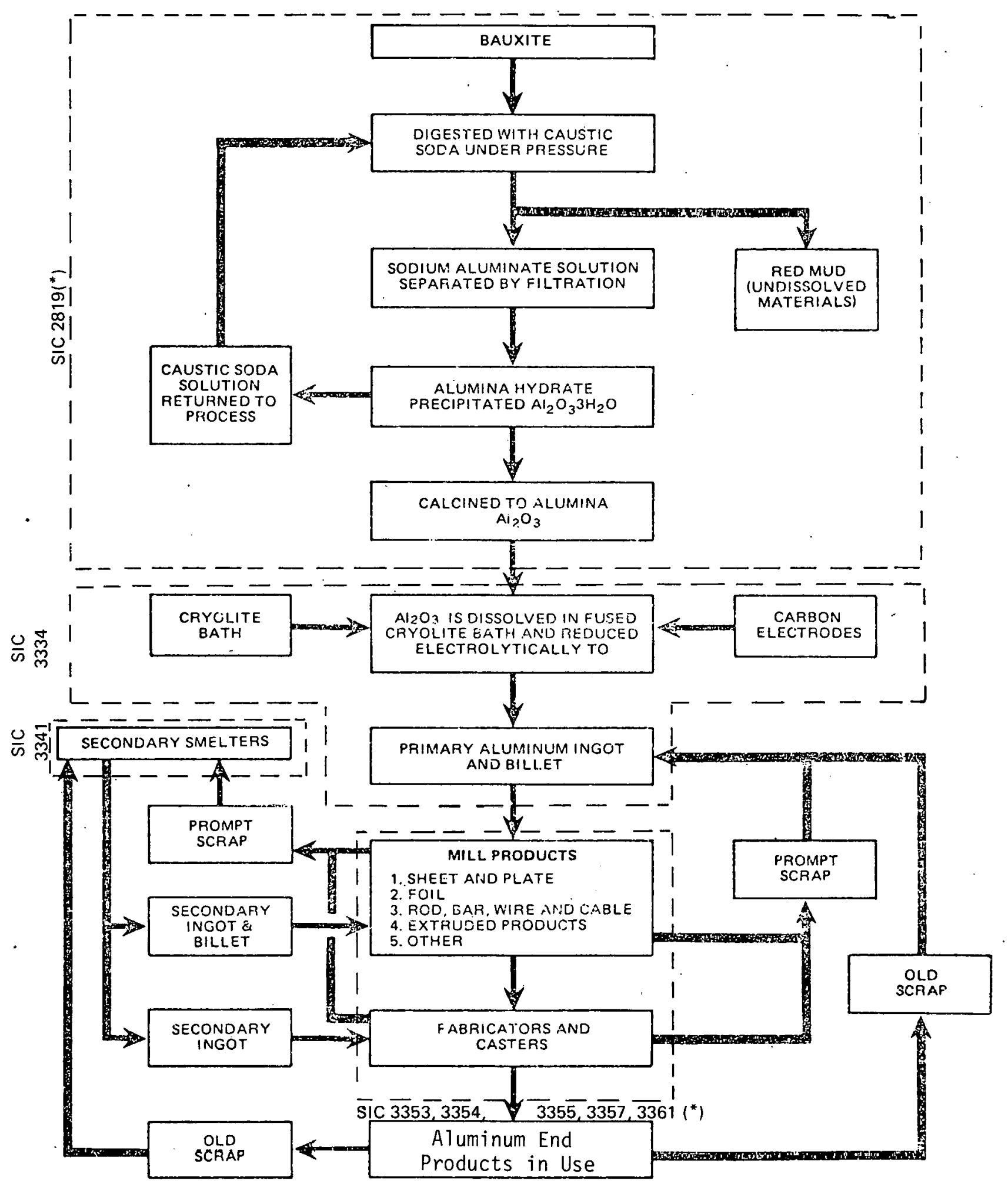

$\left({ }^{*}\right)$ Note: Some of the major primary aluminum producers use bauxite. The major primary and secondary companies also produce mill products, fabricated products and castings to varying degrees.

Source: Aluminum Prices 1974-75 Executive Office of the President

Council on Wage and Price Stability, Staff Report September 1976. 


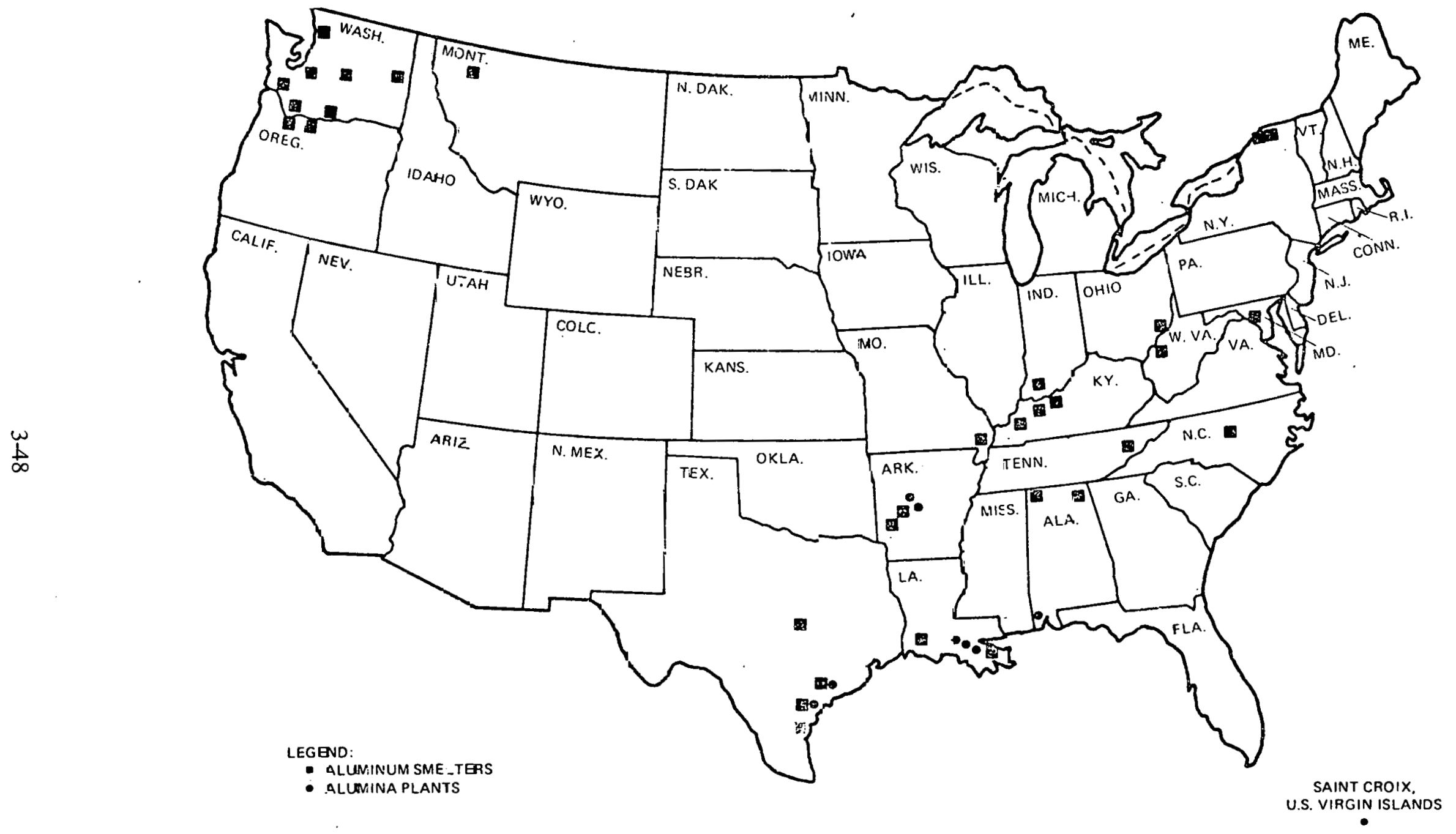

Source: Environmental Considerations or Selected Energy Conserving

Manufacturing Process Optiors: Vol. VIII. Alumina/Aluminum Industry

Report, U.S. EPA, EPA-60017-76-034h,

December 1976.

FIGURE 3.3-2 LOCATION OF ALUMINA PLANTS AND ALUMINUM SMELTERS 
TABLE 3.3-1

ALUMINA PLANTS

Company and Plant

Aluminum Company of America

Mobile, AL

Bauxite, AR

Point Comfort, TX

Martin Marietta

St. Croix, VI

Kaiser Aluminum and Chemical

Baton Rouge, LA

Gramercy, LA

Reynolds Metals Company

Hurricane Creek, AR

Corpus Christi, TX

Ormet Corporation*

Burnside, LA

Total U.S.
Capacity in 1976

(Equivalent Aluminum)

Thousand Short-Tons/Year

Plant Company

515

195

695

237

237

951

534

417

438

722

313

313

$4,066 * \star$

*A 66-34 joint venture between Consolidated Aluminum Corporation and Revere Copper and Brass, Inc.

**At an equivalency factor of 1.89 ton alumina per ton of aluminum, the total capacity in 1976 is approximately 7.7 million short tons per year.

Source: Mineral Commodity Profile, MCP-14, May 1978 and Arthur D. Little, Inc. estimates. 
TABLE 3.3-2

\section{PRIMARY ALUMINUM PLANTS}

Company and Plant

Aluminum Company of America

Alcoa, TN

Badin, NC.

tvansville, IN

Massena, NY

Point Comfort, $T X$

Rockda Te, TX

Vancouver, WA

Wanatchee, WA

Palestine, TX
Capacity in 1976

(Thousand Short Tons/Year)

Plant

Coliipany

1,675

215

125

290

215

185

310

115

205

15

Anaconda Aluminum

Columbia Falls, MT

180

Sebree, $K Y$

120

Consolidated Alıminum

New Johnsonville, TN

Lake Charles, LA

Martin Marietta

The Dalles, OR

Goldendale, WA

120

Eastalco*

Frederick, MD

176

Intalco*

Bellingham, WA

260

Kaiser Aluminum and Chemical

Chalmette, LA

260

Mead, WA

260

163

Ravenswood, WV

Tacoma, WA
179

81 
Company and Plant

Ormet**

Hannibal, $\mathrm{OH}$

Noranda

New Madrid, MO

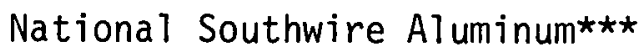

Hawesville, KY

Revere Copper and Brass

Scottsboro, AL

Reynolds Metals Company

Arkadelphia, AR

Corpus Christi, TX

Jones Mil1s, AR

Listerhill, AL

Longview, WA

Massena, NY

Troutdale, OR

Total U. S.
Capacity in 1976

(Thousand Short Tons/Year)

Plant

Company

260

260

140

140

180

180

114

114

975

68

114

125

202

210

126

130

* ALUMAX, Inc. and Howmet Aluminium Corp. each have a $50 \%$ interest in Eastalco and Intalco.

** Ormet is owned jointly by Consolidated Aluminum Corp. (66\%) and Revere Copper and Brass (34\%).

*ᄎ* National Southwire Aluminum is owned jnint.ly hy Nationnal Aluminum Company (50\%) and Southwire Company (50\%).

Source: Mineral Commodity Profile MCP-14, May 1978, and Arthur D. Little, Inc., estimates. 
In 1976, 91 plants produced secondary alloy ingot, hot metal, and extrusion ingot. ${ }^{(3)}$ Most of the secondary plants are located near heavily industrialized areas that give them proximity to a supply of scrap as well as to their customers. This is especially advantageous for the plants that provide "hot metal" to the automobile companies' casting operations. About $35 \%$ of the U.S. secondary aluminum production is done within a 100 -mile radius of downtown Chicago; another $20 \%$ can be found within a similar radius of Cleveland; and the remaining $45 \%$ is located primarily near New York City and Philadelphia, in the S.W. United States and in California. ${ }^{(5)}$ Production in individual secondary aluminum plants can range from 3,000 to 55,000 short tons per year. ${ }^{(5)}$

\subsubsection{Aluminum Foundries}

In the United States about 1400 foundries produce aluminum castings as the major metal; half of which cast aluminum exclusively. About $80 \%$ of aluminum foundries are jobbers. About 923,000 tons of aluminum castings, valued at $\$ 2.75$ billion, were produced in 1976 , representing about $40 \%$ of all nonferrous castings. ${ }^{(6)}$

Because of their light weight, castability, machinability, and hich strength-to-weight ratio, aluminum castings serve such important markets as automotive, appliance, and aerospace. The automotive industry consumed approximately half of all aluminum castings in 1976.

Aluminum foundries are heavily concentrated in the Great Lakes States where most automotive plants are located. The Pacific States, centers of the aerospace industry, also have a large number of aluminum foundries.

About $80 \%$ of aluminum foundries employ fewer than 50 people, and about half of these have fewer than 10 employees.

\subsubsection{Others}

Besides the primary and secondary aluminum producers and foundries, there are a number of companies producing a wide variety of aluminum products. Table 3.3-3 is based on unofficial directories currently prepared by the U.S. Department of Commerce Domestic and International Business Administration. The figures show the number of companies and plants involved in the manufacture of each product. In many instances, one company operates more than one plant. No totals are shown since some plants produce more than one product. The data alsn inclunde captive plants, i.e., those producing only for one company's use. In many instances, the companies that own these plants are generally small and are scattered around the country. The companies exhibit little or no concentration.

\subsubsection{Process Technology}

\subsubsection{Primary Metal Production}

Primary aluminum metal is produced from alumina by the Hall-Heroult electrolytic reduction process. Alumina is produced by refining bauxite via the Bayer process. Both these processes are briefly dçcribcd below.

\subsection{Bayer Process}

In the Bayer process, finely ground bauxite ( -35 mesh), usually wet ground in spent digestion liquor, is digested at elevated temperatures under pressure. The digesting liquor contains sodium aluminate and free caustic. 
TABLE 3.3-3

DISTRIBUTION OF COMPANIES AND PLANTS INVOLVED

IN THE MANUFACTURE OF VARIOUS ALUMINUM PRODUCTS*

(January 1978)

\section{Products}

Primary Ingot

Secondary Ingot

Master Alloys

Sheet and Plate

Foi 1

Extruded Shapes

Rolled and Continuous Cast Rod and Bar

Wire, Bare, Conductor and Nonconductor

ACSR and Cable, Bare

Wire and Cable, Insulated or Covered

Drawn Tube

Welded Tube

Flake, Powder and Paste

Forgings

Impacts (including collapsible tubes and cans)
Number of Number Companies of Plants

$\begin{array}{rr}12 & 32 \\ 69 & 89 \\ 9 & 9 \\ 29 & 49 \\ 18 & 27 \\ 149 & 222 \\ 16 & 31 \\ 59 & 125 \\ 28 & 59 \\ 41 & 90 \\ 18 & 22 \\ 25 & 32 \\ 13 & 18 \\ 64 & 74 \\ 25 & 29\end{array}$

*Prepared for government use and not to be considered official or complete.

Source: Directory of Aluminum Suppliers in the United States, U.S. Department of Commerce, Industry and Trade Administration, Bureau of Domestic Business Development Office of Basic Industry. 
The Bayer process is shown schematically in Figure 3.3-3. The ranges of raw materials and energy required per short ton of alumina produced in the U.S. Bayer plants are shown in Table $3.3-4$

\subsection{Hall-Heroult Process}

This is an electrolytic reduction process in which alumina is continuously dissolved in molten cryolite in the cell wherein aluminum is liberated at the cathode and oxygen at the anode. The oxygen liberated at the anode reacts with the carbon anode to produce a mixutre of carbon monoxide and carbon dioxide.

Modern Hall-Heroult electrolytic cells are large steel boxes lined with insulating refractory and carbon. Carbon blocks at the bottom of the cell serve as the cathode in the electric circuit and form a connector to steel conductor support members that eventually connect. to the cathode bus. During electrolytic reduction, aluminum metal is deposited as liquid on the surface of the carbon cathode at the bottum of the cell. This pool of molten aluminum is the active cathode. Cathodes are more or less a permanent installation. Typically, the cathodes last three to six years, about the same as the life of the cell itself, after which time the cell is taken out of service, rebuilt, and refitted. Cathodes are purchased from carbon producers, while anodes are produced at the aluminum plants.

The anodes are also carbon, suspended in the electrolyte on steel conncector rods that connect to the anode bus. The carbon anodes used in the reduction cells are produced by two methods, Soderberg or prebake, both of which use a combination of petroleum pitch.and petroleum coke. In the Soderberg system, "Soderberg paste" is fed semi-continuously into the top of the steel casing, in which the heat from the cell and current flow bakes the paste and removes the volatiles.

In the prebake system, prebaked anodes are manufactured in a separate installation from high-purity petroleum coke, which is ground, calcined, and blended with pitch to produce a paste that can be pressed into high-density shapes. Approximately 1975 pounds of petroleum coke plus about 444 pounds of pitch are required to produce a short ton of anode carbon. The pressed anode blocks are then baked at temperatures up to $2000^{\circ} \mathrm{F}$ for as long as 30 days (baking and cooling period) and fitted with steel connector rods to support the anode and provide a connection to the anode bus. Molten cast iron is poured into the anode socket to make a good electrical connection between the steel rod and the carbon anode. The prebake system has a number of advantages over the Soderberg system. It requires significantly less energy than the Soderberg system and because the anodes are baked in separate facilities, it is easier to recover the volatiles released from the anode paste.

Aluminum reduction cells operate continuously with periodic additions of alumina and electrolyte additives, replacement of anodes, and removal of molten aluminum. Aluminum is removed periodically at one- to three-day intervals and blended with the output of other cells to attain a uniform purity level. 'The blended material is degassed and cast into ingots or sows or is delivered as molten metal to fabricating plants.

The ranges of raw materials and energy required for U.S. primary aluminum plants are shown in Table 3.3-5. 


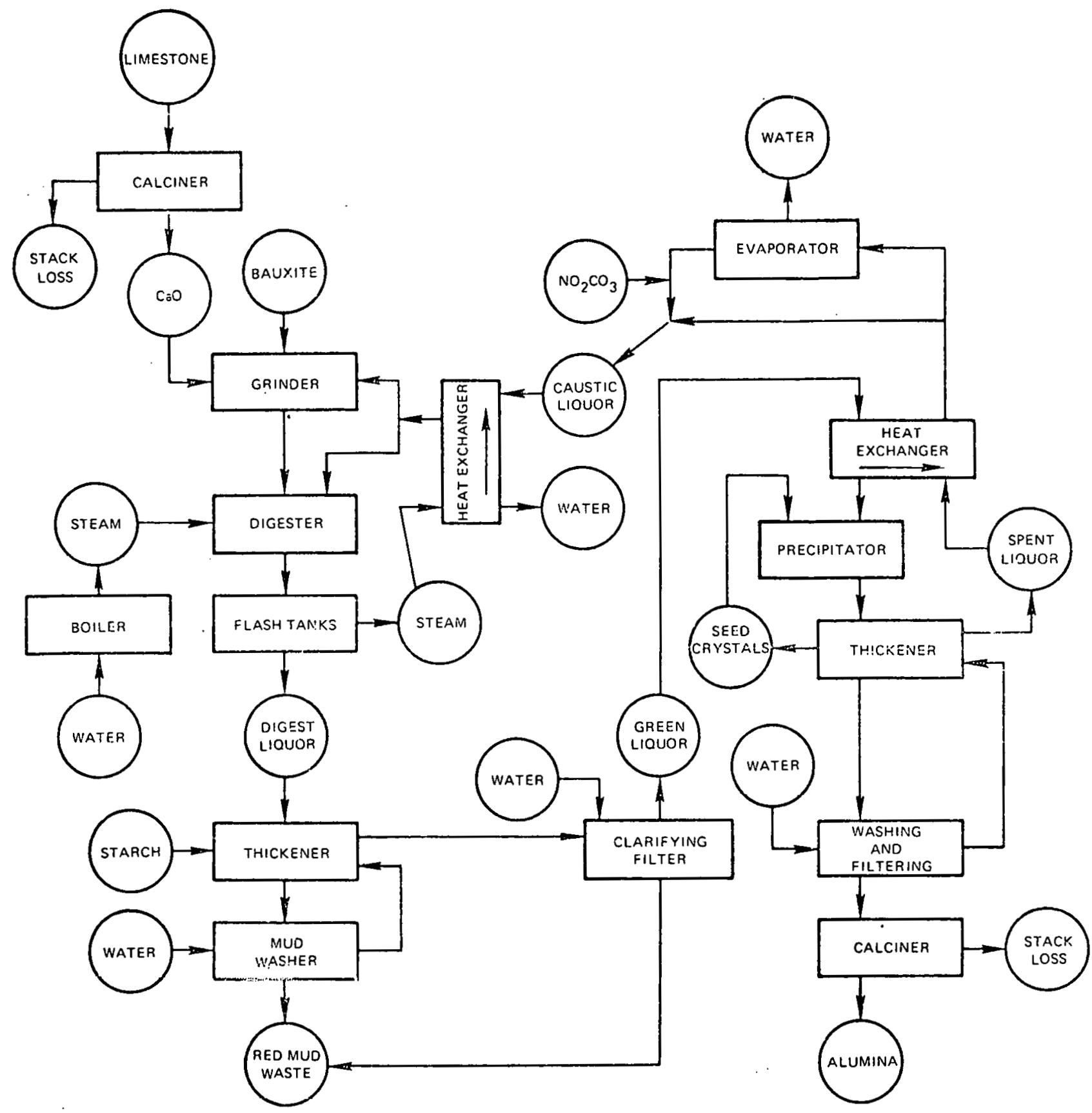

Source: Environmernlal Considerutions of Selocted Energy Conserving

Manufacturing Process Options: Vol. VIII. Alurmina/Aluminum Industry

Report, U.S. EPA, EPA-60017-76-034h,

December 1976.

FIGURE 3.3-3 BAYER PROCESS FOR PRODUCING ALUMINA 
TABLE 3.3-4

\section{BAYER PLANTS - RANGES OF RAW MATERIALS}

AND ENERGY REQUIREMENTS

\begin{tabular}{lc} 
& \multicolumn{2}{c}{ Range } \\
Raw Materials: & ton/ton Alumina \\
Bauxite & $2.05-2.63^{*}$ \\
Limestone & $.09-.18$ \\
Soda Ash & $.05-.1$ \\
Starch & $.005-.01$ \\
& \\
Power: & kWh/ton Alumina \\
& $200-300$ \\
Fuel: & \\
Steam generation & Btu/ton A7umilld \\
Lime calcination & $4.4-11.3$ \\
Alumina calcination & $.21-.13$ \\
\end{tabular}

*Bauxite consumption varies from 2.05-2.37 for South American bauxite and 2.41-2.63 for Caribbean bauxite.

Snurce: Environmental consideraliums of Selected Eneryy Conserving Manufacturing Process Options: Vol III, Alumina/ATuminum Industries Report, EPA, December 1976.

Mineral Commodities Prof11e, MCP-14, May 1978. 


\section{TABLE 3.3-5}

PRIMARY ALUMINUM PLANTS - RANGES OF

RAW MATERIALS AND ENERGY REQUIREMENTS

(Prebaked Operation)

Raw Materials:
Alumina
Calcined Petroleum coke
Pitch
Cryolite
Aluminum Fluoride
Calcium Fluoride

Power:

Fuel:

Baking Anodes

Casting
Range

ton/ton Aluminum

$1.91-1.95$

$0.43-0.60$

$0.10-0.20$

$0.01-0.05$

$0.01-0.05$

$\mathrm{kWh} /$ ton Aluminum

$14,000-18,000$

$10^{6}$ Btu/ton Aluminum

$2.3-3.6$

$1.5-11.0$

Source: Environmental considerations of Selected Energy Conserving Manufacturing Process Options: Voi III, Alumina/ATuminum Industry Report, EPA, December 1976. 


\subsection{New Processes}

The possibility of producing alumina from such domestic alumina-bearing raw materials as alunite, kaolin and anorthosite clays is of increasing interest. Nitric acid and hydrochloric acid leaching processes were identified by the U.S. Bureau of Mines as the most economic for producing alumina from domestic clays.$^{(7)}$ Clay chlorination, as in the Toth alumina process, and the Alcoa chloride process, also offers an alternative to the Bayer process and appears to be commercially viable for primary aluminum production, based on the limited information available.

Alcoa announced its new electrolytic chloride process for aluminum smelting in 1973. The process involves the electrolysis of aluminum chloride from an electrolyte consisting of alkali and alkali earth chlorides. Alcoa has built a demonstration plant in Palestine, Texas with an annual capacity of 15,000 short tons per year and possible expansion to 30,000 short tons per year. The Alcoa chloride process starts with pot feed alumina from the Bayer process. Specifications call for a minimum purity of $99.426 \%$ alumina. This alumina is chlorinated in the presence of carbon to form volatile aluminum chloride. This, in turn, is purified and fed to the electrolytic cells to produce moltèn aluminum at the cathode and chlorine at the anode. The chlorine is recycled to the chlorination system. The Alcoa chloride process is shown schematically in Figure 3.3-4. The advantages of this process over the existing Hall oxide electrolysis appear to be:

- Because the decomposition voltage and the bath resistivity are both lower for the chloride melt, the electrical energy requirement is sharply reduced.

- Because oxygen is eliminated from the system, it is not necessary to fabricate and replace the consumable carbon anodes. Permanent graphite electrodes can be used, and the expensive energy-consuming anode baking facilities are eliminated.

- Because electrodes can now be permanently emplaced, it is possible to design chloride process cells with multiple sheet electrodes stacked one above another (the so-called "multipolar" electrode configuration). One cell then becomes the equivalent of several single cells, with consequent savings afforded by the much more compact cell design.

- Because no cryolite or fluoride materials are used in the chloride process, fluoride emissions are completely avoided.

- The chloride cell operating temperature is about $1292^{\circ} \mathrm{F}$ rather than the $1742^{\circ}-$ $1832^{\circ} \mathrm{F}$ temperature of the Hall process.

Several refractory hard metals have been considered in the past to replace the carbon cathodes in the conventional Hall-Heroult process. So far, the principal interest has been in titanium diboride because of its superior electrical conductivity, and the fact that it is wetted by molten aluminum and cryolite in the cell. Also, in the pure state it is not corroded by the electrolyte. Thus, there is hope that this material, properly fabricated, would last at least four years since the cell itself has a normal life of four years. Recently, interest has shifted to replacing not only the iron and carbon, but also the molten aluminum pad so that the titanium diboride would provide connections between the cathode bus and the electrolyte. The aluminum produced at the cathode could be rapidly removed or drained from the cathode with only a thin film of molten aluminum remaining on the cathode. 


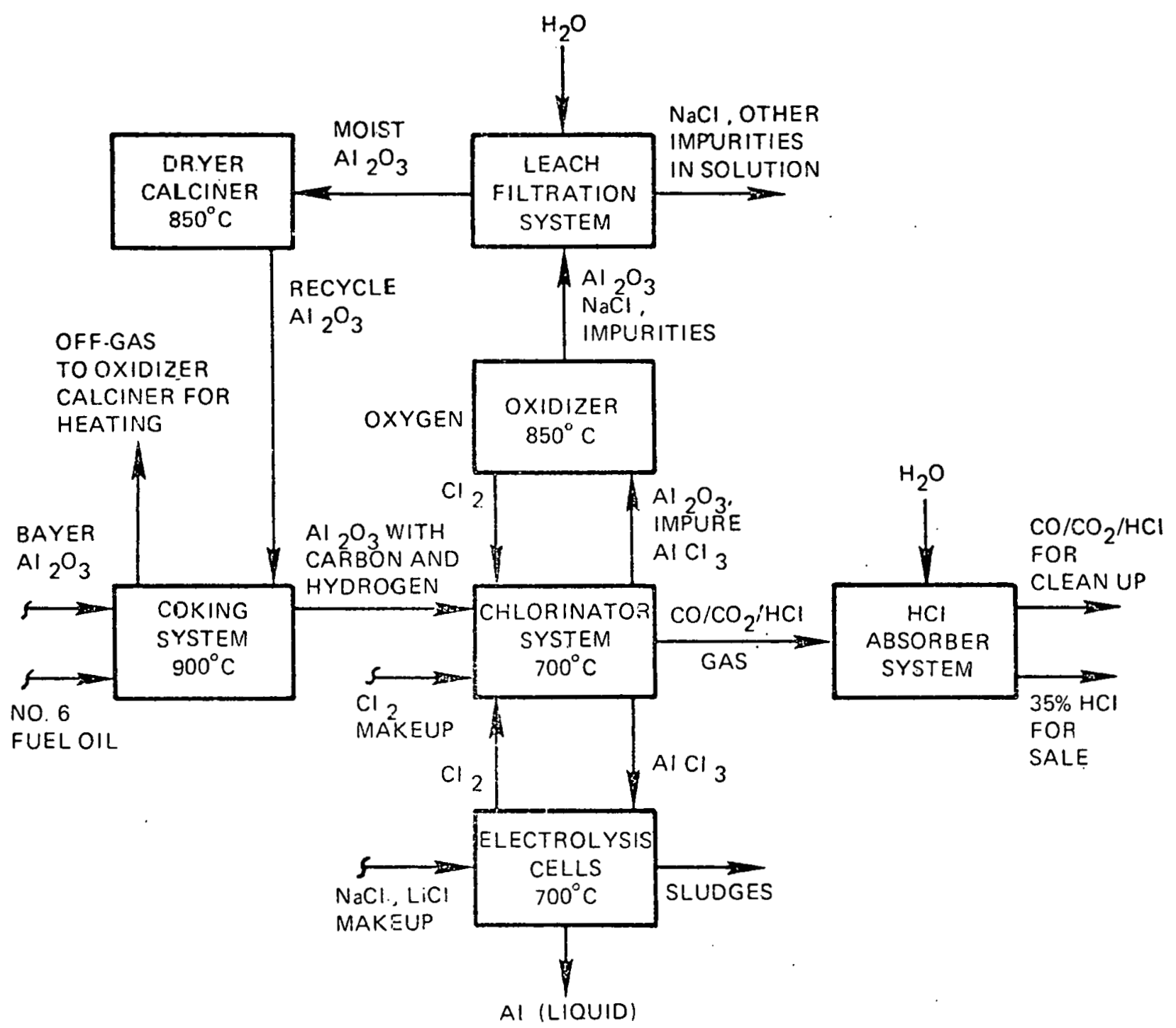

Scurce: Environmental Considerations of Selected Energy Conserving

Manufacturing Process Options: Vol. VIII. Alumina/Aluminum Industry

Report, U.S. EPA, EPA-60017-76-034h,

December 1976. 
It appears that a power saving of the order of $20-25 \%$ might be achieved. This would result from reducing the anode/ cathode distance, thereby reducing the voltage drop and the resistance losses. At least two companies, Kawecki Berylco Industries, Inc. and PPG Industries, believe that past difficulties with titanium diboride have now been overcome, and that they could demonstrate 3-4 years cathode life and the advantages of titanium diboride cathodes to the primary aluminum companies.

\subsubsection{Secondary Metal Production}

The production of secondary aluminum consists of three steps: presmelting, smelting, and pouring and cooling of products. These steps are briefly described below.

\subsubsection{1 l'resmelting}

The preliminary treatment in preparing scrap for smelting depends on the type of scrap fed to the smelter. There are seven types of scrap as follows:

- New Scrap

- Solids and Clippings

- Borings and Turnings

- Dross and Skimmings (Residues)

- Other (includes foil and high-iron scrap)

- Old Scrap

- Castings, Sheet and Clippings

- Aluminum Cans

- Other (includes aluminum-copper radiators and other high-iron scrap).

New solids and clippings arc largely uncontaminated and require little presmelter treatment. Iron inclusions or other non-aluminum contaminants, are removed either manually or mechanically (shredding and magnetic separation). Scrap consisting of borlngs and turnlngs ls often contaminated with cutting oils. It is first shredded in ring crushers and then dried in rotarykiln type dryers. The borings are then passed over magnetic separators where iron is removed and the clean dry borings are sent to storage for later use.

Drosses and skimmings are generated when aluminum ingot or scrap is melted or when moltcn aluminum is handled. The primary constituents of dross are aluminum metal and alumina, but significant quantities of other constituents may be present. These include aluminum carbide and aluminum nitride; other metals and their oxides, depending on the alloy composition of the melt; fluorine compounds; if the aluminum comes from a reduction cell; and residues of fluxes used to control melt loss or alloy properties, or to treat dross in the melting or holding furnace. The most valuable constituent of dross is the free aluminum .

When dross is formed in the furnace the metal content is usually high (about 60-80\%), bul it is much lower by the time it is skimmed off because aluminum oxide has formed. Hence the method of cooling and handling dross has an important bearing on the metal content of dross. Dross cooling machines have been adopted by the industry. The dross is skimmed into a suitably designed dross pot which is then taken to a cooler where some metal may be drained off and the remainder is broken up into small pieces and cooled rapidly on a water cooled, steel-faced. 
shaking conveyor. By these means the metal content of the dross, half of which may be lost if the hot dross is dumped on the floor in the dross room, is conserved. ${ }^{(8)}$ In a melting or holding furnace, if the melt is fluxed with gaseous chlorine or fluxes such as fluorides, exothermic reactions occur, which cause the aluminum entrained in the dross to drain out. The resultant dross usually contains $20-30 \%$ aluminum.

The most common method for processing drosses, skimmings, and slags containing $30 \%$ metallics consists of milling, screening and magnetic separation to obtain a concentrate containing $60-70 \%$ metal. This concentrate is suitable for charging to a melting furnace. Oxides and dust are loosened from the metallics by crushing in a ball mill, rod mill, or hammer mill and are removed by screening or air-separation. The undersize fraction containing oxides and five metallics is sold as an exothermic material for hot-topping ingots or is discarded. Rich metallic skims do not require milling prior to use.

A wet process has been used, principally for drosses and skimmings containing salt flux. ${ }^{(9)}$ The dross is fed into a long drum and washed with water to dissolve the salts. The washed residue is then screened, dried, and poured through a magnetic separator before being fed to the melting furnace. The salt-containing solution is evaporated to recover the salt flux.

In addition, drosses have been processed in a rotary salt bath furnace. The oxides are removed by salt flux to produce a slag and the entrained metal drains out. A recent development consists of using a low-frequency coreless induction furnace to recover metal from dross using a salt flux. This process provides good metallic recovery for drosses containing more than $50 \%$ metal.

Old scrap consisting of castings and sheet is sometimes baled or briquetted, or large pieces may be added to the melting furnace. When it has enough iron rivets, bushings and other tramp contaminants, the scrap is usually shredded and subjected to magnetic separation.

Old aluminum cans may be shredded, or baled for shipment and then shredded at the smelter. Another operation that may be practiced as a separate step is delacquering, which involves heating the cans at a temperature below the melting point to remove the organics. Alternatively, the shredded cans are charged directly to the melting and holding furnace along with virgin aluminum, prepared new ocrap and runarvund scrap.

Presmelting preparation of other scrap (new and old) consists of size reduction (crushing or shredding) and magnetic separation or "sweating." Sweating consists of selectively melting the aluminum alloy (melting point of about $1100^{\circ} \mathrm{F}$ ) at a temperature below the melting point of iron or steel and letting the molten aluminum fraction flow into a ladle or mold while the ironcontaining portion is raked out of the furnace. Aluminum wire scrap is first chopped and is then used for alloying or as a deoxidant in steelmaking.

\subsection{Smelting}

In smelting scrap, only those elements that are higher than aluminum in the electromotive series can be removed from the melted scrap charge. In producing the secondary aluminum alloy, then, the smelter has to add primary ingots (or high-purity scrap) to the molten scrap charge to bring the composition up to the desired specification. 
The smelting of aluminum takes place in a reverberatory furnace or in a rotary furnace. The reverberatory furnace ranges in capacity from 30,000 to $180,000 \mathrm{lb}$, and may be either gas-fired or have dual-firing (gas and oil) capability. Some furnaces have one or two external charging wells or forewells (for charging scrap), separated from the main hearth of the furnace by a refractory wall called a "hot wall." Other furnaces have removable lids for charging of scrap. The hot wall has two openings, connecting the hearth and the charging wells, which are sometimes covered with a skim gate (external) to prevent scrap and skimmings on the molten metal surface from getting inside the furnace. Heat is conveyed from the burner flame by convection and radiation from the roof and sidewalls to the molten metal inside the furnace hearth, and by convection, radiation, and conduction to the scrap in the charging well.

Scrap is charged to the furnace either manulally or mechanically through side doors, or the top of the furnace or the forewell depending on furnace design. A "molten heel" - molten metal of known composition left over in the bottom of the furnace from a previous heat - can be used to shorten the heat time. If a liquid heel is not maintained in the furnace, heavy solids are firot charged into the furnace. The material must then be completely melted, skimmed, sampled, and assayed before other materials can be added. After each charge, the slag is skimmed off and the metal is sampled to determine its composition. It is normally economical to minimize the need for using alloying elements, such as copper and silicon, by charging scrap as close in composition to the alloy being produced as possible.

Because molten aluminum oxidizes rapidly, it is sometimes covered with a flux to retard oxidation. Once the oxides are trapped in the flux they are removed by skimming. Alloying agents (such as copper and silicon) are normally added after the metal composition has been determined, and the melt is brought to specification.

'The specifications for must of the major alloys supplied to the diecastings industry call for a magnesium content of less than $0.1 \%$. In spite of the fact that scrap is carefully selected so that the charge will meet product specifications, the bath still usually contains $0.5 \%$ to $0.8 \%$ magnesium. Excess magnesium is removed from the bath through the addition of aluminum fluoride or chlorine gas referred to as demagging. Finally, the metal is degasified by bubbling nitrogen, chlorine, or a mixture of the two. The molten bath is then ready for pouring. The overall metal recovery of the reverb melting scheme is around $90 \%$. With very clean scrap, metal recovery could be as high as $98 \%$. Metul losses are mostly to the slag, which is stored until shipped to a residue processor, reprocessed by the cumpany, or dumped.

Alloys for extrusion billet manufacture are also melted in reverb furnaces, but the scrap used is restricted to certain alloys that require the addition of magnesium and, possibly, primary aluminum ingot to dilute the bath to specification.

In production of deoxidizers for the steel industry, reverb melting is utilized. Because the magnesium content is not critical, demagging is not required. These alloys are produced as notched bars or shot.

Hardeners are produced in the form of small notched bars and are used to introduce precise amounts of metals such as titanium, boron and chromium for alloying purposes. These bars are produced in small induction furnaces of 2,000-pound capacity. Since this aluminum must be of high purity, ordinary aluminum scrap cannot be used. Chopped aluminum wire or ACSR 
conductor with the iron core removed is generally used. Casting is done at temperatures of $2000^{\circ} \mathrm{F}-2200^{\circ} \mathrm{F}$ after the metal is skimmed to remove oxides.

\subsection{Pouring and Cooling of Products}

The molten aluminum is either cast into shapes such as ingots, billets and notched bar, or is made into shot. Metal is also delivered to a customer as "hot metal." Hot metal is tapped from a reverb furnace directly into preheated ladles at approximately $1550^{\circ} \mathrm{F}$. Refractory-lined ladles are placed on a special flat-bed trailer capped with a screw-down lid and chained rigidly to the truck bed. The hot metal is hauled by truck directly to the customer and discharged into the customer's holding furnace at a temperature of about $1350^{\circ} \mathrm{F}$. The average load of hot metal is $30,000-35,000$ pounds. Ladles have bottom-tap arrangements so that the metal can be poured directly into the customer's furnaces using the ladles, instead of by removing the ladle from the trailer.

\subsubsection{Aluminum Foundry Technology}

Most aluminum foundries (over $90 \%$ ) have less than a 5 tons per hour melting capacity. Although $65 \%$ use sand casting and only $25 \%$ use die casting, a much larger proportion of castings are produced by die casting (about $65 \%$ ) than sand castings (about 13\%). The rest are produced by permanent mold techniques. Oil sand, carbon dioxide process, and shell core are the principal coremaking techniques used in the aluminum foundry industry.

Though crucible melting is the most common melting method - used in over $80 \%$ of the foundries, the largest share of the melting capacity is tied with the reverberatory furnaces.

\subsubsection{Materials Flow}

\subsubsection{General}

Materials flow in the aluminum industry exhibits a complex pattern. In 1976, domestic primary metal production was 4.3 million short tons, valued at approximately $\$ 3.79$ billion. Of this, the domestic bauxite supply was sufficient for about 0.4 million short tons of aluminum. The remaining 3.9 million short tons (or $90.9 \%$ of the total primary) were obtained from imported bauxite and alumina. ${ }^{(10)}$ The 1976 domestic secondary recovery was an estimated 1.5 million short tons. ${ }^{(11)}$ This primary and secondary production, together with the imports and inventory change, constituted the aluminum metal flow. Figure 3.3-5 shows schematically the aluminum metal flow in 1976.

\subsubsection{Classification of Recoverable Material}

Figure 3.3-5 shows that aluminum-based scrap is an important element in the flow pattern. Scrap may be pure (unalloyed), segregated (one alloy type), or mixed (two or more alloys). New scrap is generated in the manufacture of primary aluminum, semifabricated aluminum mill products, or finished industrial and consumer products. This new scrap includes solids, such as new casting scrap, clippings or cuttings of new sheet, rod, wire, and cable; borings and turnings from the machining of aluminum parts; and residues, drosses, skimmings, spillings, sweepings, and foil.

New scrap is further defined as either "runaround" (home) scrap or purchased scrap. Runaround or home scrap is new scrap generated by fabricators of aluminum mill products or by aluminum castings foundries and recovered or recycled by the same company that generates it. 


\section{MINERAL COMMODITY PROFILES}

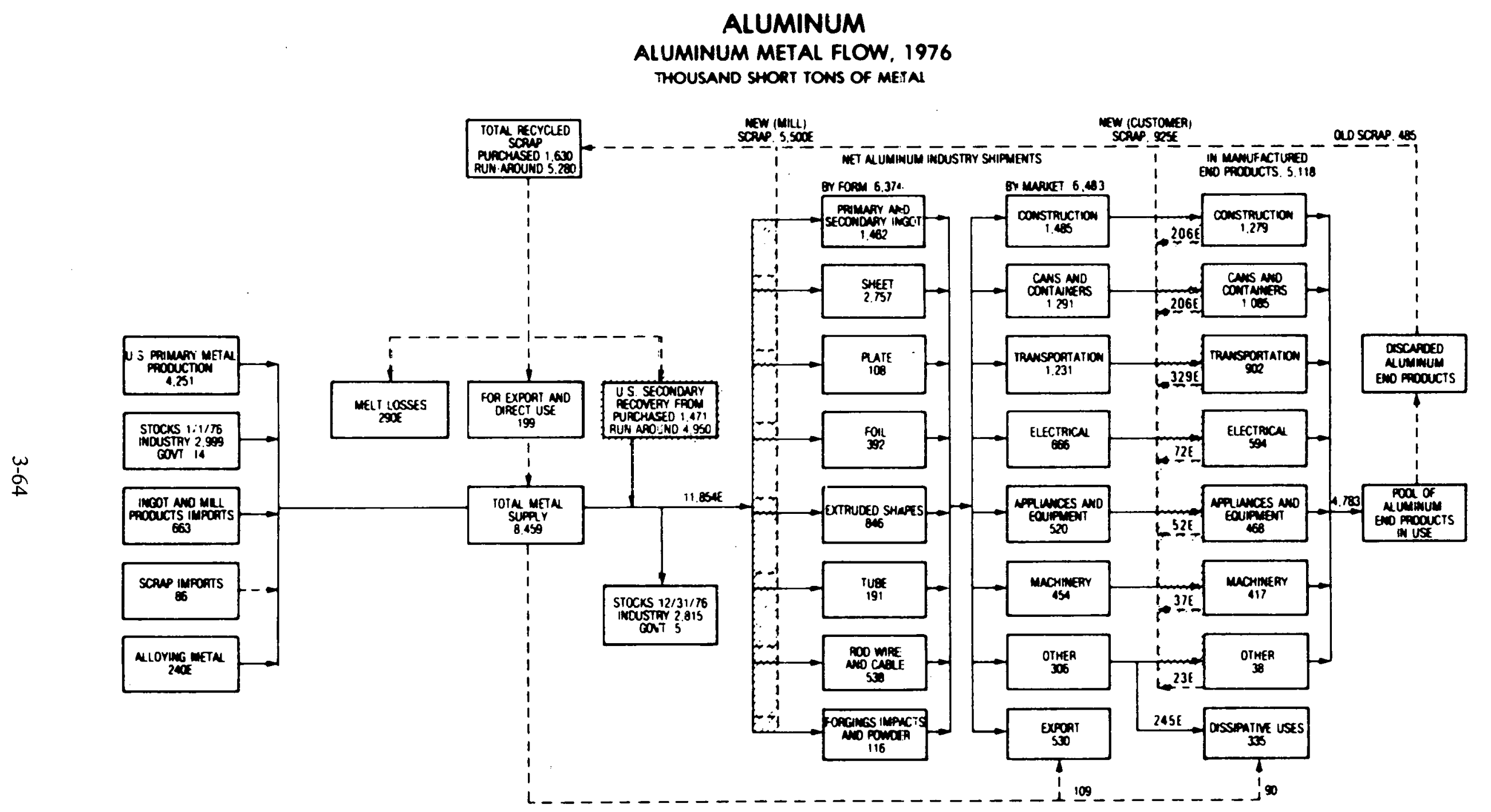

(a)

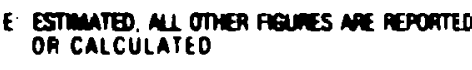

$---\operatorname{scs}$

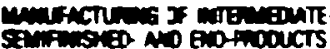

FIGURE 3.3-5 ALUMINUM METAL FLOW - 1976

Source: U.S. Bureau of Mines Mineral Commodity Profiles - Aluminum, 1978, p. 18. 
Primary smelters also create and use runaround scrap. Such scrap, by definition, never leaves the company generating it and therefore is never marketed as scrap. Purchased scrap is new scrap purchased, imported, or treated "on toll" by secondary smelters, the original aluminum product suppliers, or others. New aluminum scrap purchased from manufacturers of end products may be referred to as customer scrap. Purchased scrap is sometimes referred to as prompt industrial scrap.

Old scrap, all of which is considered as purchased, comes from discarded, used, and wornout products. It includes aluminum pistons or other aluminum engine or body parts from junked cars, used aluminum cans and utensils, siding, awnings and other building products, and old wire and cable. Sweated pig is scrap that has been sweated or melted into a pig or ingot form for convenience and economy in shipping. Obsolete scrap is unused, but technologically obsolete aluminum parts, outdated inventory materials, production overruns, and spare parts for machines and equipment no longer being used. In the United States both sweated pig and obsolete scrap are considered old scrap..$^{(9)}$

Table 3.3-6 shows the classification of purchased aluminum base scrap; typical contents, origin, and the level of recycling followed in the industry. Since the runaround or home scrap does not enter the market, there are no data on this scrap.

\subsubsection{Recycling Profile}

Figure 3.3-5 shows that aluminum-based scrap is an important element in the flow pattern. More than $90 \%$ of the new scrap generated in the production of end products is recycled to the production cycle almost immediately. ${ }^{(10)}$ The total supply of new scrap is a direct function of aluminum production levels. The market supply of new scrap depends on total supply, the amount reused within the generating plant, and the amount of scrap "buy-back" under toll conversion agreements.

The recycle time for old scrap, virtually all of which is purchased, varies considerably depending on the form and end use, and is normally much longer than for new scrap. ${ }^{(10)}$ The potential supply of old scrap is a direct function of the stock of aluminum goods and their age. The actual supply of old scrap is a function of the price of scrap, technological considerations, and transportation costs. ${ }^{(5)}$

Table 3.3-7 shows the consumption of purchased new and old scrap, and sweated pig. Of the total scrap consumed in $1976,51.8 \%$ was used by secondary smelters and $24.9 \%$ by primary producers. Table 3.3-8 shows the reported purchased scrap consumption in 1976 by type of scrap. Of the total 1.5 million short tons purchased scrap (as reported) new scrap represented 1.06 million short tons $(71.9 \%$ of the reported total): The remainder was made up by old scrap, including sweated pig.

The Aluminum Association reported that in 1976, based on partial industry coverage, 106,000 short tons of aluminum representing 4.8 billion aluminum cans were reclaimed. ${ }^{(3)}$ In 1977 , 140,000 short tons of aluminum were reclaimed representing 6.4 billion aluminum cans. ${ }^{(3)}$ Reynolds, in 1977 , reclaimed about $48 \%$ of total aluminum cans recycled and represented more than $55 \%$ of the total number of cans produced by Reynolds. ${ }^{(12)}$ 


\section{CLASSIFICATION OF ALUMINUM BASE PURCHASED SCRAP}

Scrap*

\section{New Scrap}

Solids and Clippings

Borings and Turrir.gs

Foil

ڤ̆

Drosses and Skimmings

Other

old Scrap

Castings, Sheet ard

Clippings

Aluminum Cans

Automotive, Other

Sweated Pig
Typical Conzents

Clippings-painted \& containing $\mathrm{Cu}$ and $\mathrm{Zn}$ alloys in a segregated (by alloy) or mixed form; forgings; special casts and alloj solids.

Borings--segregated or mixed; turnings--contaminated or clean.

Alurinum oxide, metallic aluminum and aluminum salts.

Scr $\equiv$ p containing high iron content.

Cast \& sheet products; cableinsulated, steel reinfcrced.

41 uminum-copper radiators.

Mixture of aluminum base scrap.
Aircräft industry; fabricators and manufacturers.

Machining of castings, rods, bars, etc.; aircraft and automabile industries.

Manufácturers

Primary and secondary aluminum producers.

Level of Recycling Followed *

High

Moderate to-high

Moderate

Moderate

Low to Moderate

Manuficturers \& end-users. Low

Consuriers, collectors of cans \& municipa refuse.

Automabile junk yards.

Moderate

Manufãcturers \& fabricators.
Low

Low

*Scrap categories are those fublished by Bureau of Mines.

**Preliminary Artrur D. Littl I, Inc. estima:es. 
TABLE 3.3-7

CONSUMPTION OF AND RECOVERY FROM PURCHASED NEW

AND OLD ALUMINUM SCRAP - 1976

Class

Secondary Smelters

Primary Producers

Fabricators

Foundries

Chemical Producers

Total
Consumption*

758,992

365,190

121,212

99,907

120,161

$1,465,462$
Calculated

Aluminum Recovery

$$
598,765
$$$$
314,248
$$$$
107,506
$$

86,458

46,139

$1,153,116$

*As reported by companies to U.S. Bureau of Mines. On a full industry coverage basis, the total scrap consumption is estimated to be 1,741,000 short tons, with calculated aluminum recovery of 1,371,000 short tons and a metallic recovery of $1,471,000$ short tons.

Source: Aluminum, Preprint from Minerals Yearbook, 1976. 
TABLE 3.3-8

CONSUMPTION OF ALUMINUM SCRAP BY TYPE - 1976*

$(1,000 \text { short tons })^{\star \star}$

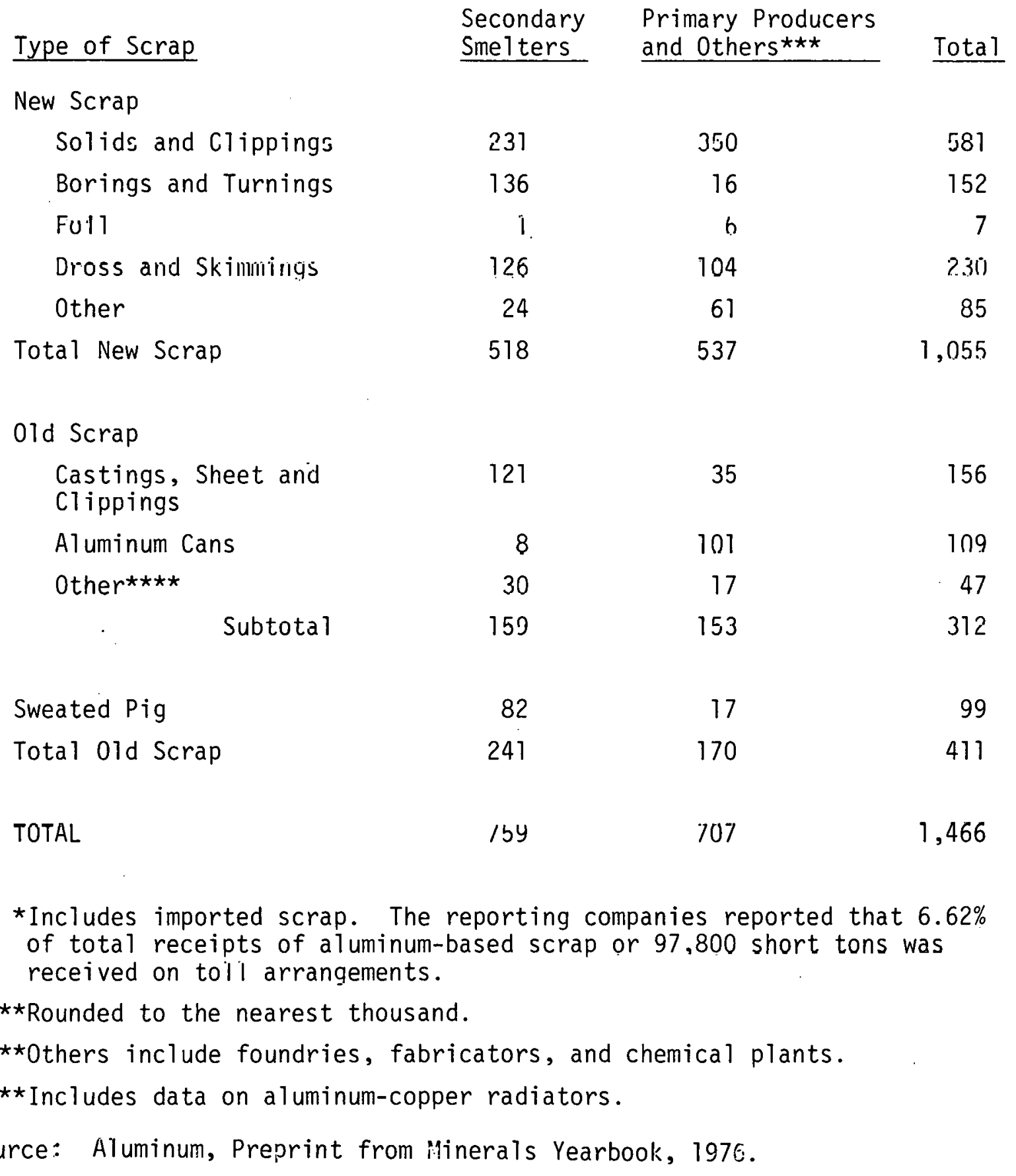




\subsubsection{Future Trends}

Aluminum is a relatively new metal. Its historical growth for each market and application can bc attributed to two main factors - economics and properties. Table 3.3-9 shows the historical aluminum shipments by markets for 1972 through 1977, as reported by the Aluminum Association. Building and construction, transportation, and containers and packaging markets accounted for approximately $50-65 \%$ of the total shipments in 1977. The term "statistical adjustment" in Table 3.3-9 refers to net shipments of aluminum reported by the Bureau of Census, which the Aluminum Association believes were overstated (or understated in 1977) by the percentages shown.

In recent years, increasingly refined statistical data has been published by the industry associations and the federal government. Because of the complexity of the aluminum metal flow and the nature of the industry, statistics on future growth from different sources should not be combined arbitrarily. In this section, for illustrative purposes, the future growth scenario is excerpted from the information published by the Bureau of Mines. ${ }^{(10)}$

The Bureau of Mines has estimated that total demand for aluminum in metal and nonmetal form will be 10.7 million short tons in 1985 and 20 million in 2000 . The apparent aluminum metal consumption data for 1972 through 1977, as well as the projected demand by the Bureau of Mines are shown in Table 3.3-10. This table does not include non-metal aluminum demand. The apparent aluminum metal consumption is defined by the Bureau as the difference between apparent aluminum supply available for domestic manufacturing and aluminum metal recovery from purchased new scrap. The secondary metal reported in Table 3.3-10 reflects recovery from old scrap only. Between the base year of 1976 for this study and 1985, secondary metal recovery from old scrap is projected to increase from 409,000 short tons to 900,000 short tons (approximately $7.4 \%$ annual growth).

\subsection{COPPER}

\subsubsection{Industry Definition}

The domestic copper industry is defined here to encompass all firms included in the following SIC categories:

SIC $3331 \quad-$... Primary Smelting and Refining of Copper

SIC 33412 - Secondary Copper

SIC 3351 - Rolling, Drawing and Extruding of Copper

SIC 3362 - Brass, Bronze and Copper Foundries

\subsubsection{Definition of SIC Classifications}

- SIC 3331 Primary Smelting and Refining of Copper - includes establishments primarily engaged in smelting copper from the ore, and in refining copper by electrolytic or uther pröcesses.

- SIC 33412 Secondary Copper - includes establishments primarily engaged in recovering copper from copper and copper-based alloy scrap by utilizing a variety of melting and refining methods. (Establishments primarily engaged in assembling, gathering, and breaking up scrap metal without smelting and refining are classified in trade industries.) 
TABLE 3.3-9

ALUMINUM SHIPMENTS BY MARKETS - 1972-1977*

\begin{tabular}{|c|c|c|c|c|c|c|}
\hline & & & & & & \\
\hline & 1972 & $\underline{1973}$ & $\underline{1974}$ & $\underline{1975}$ & $\underline{1976}$ & 1977 \\
\hline Building Construction & 26.5 & 24.7 & 22.9 & 22.6 & 23.1 & 23.0 \\
\hline Transportation & 18.5 & 19.2 & 17.8 & 17.2 & 19.3 & 21.7 \\
\hline rontiainers \& Packaqinq & 15.0 & 14.0 & 16.5 & 20.2 & 20.2 & 20.8 \\
\hline Electrical & 12.7 & 12.6 & 13.4 & 12.2 & 10.3 & 10.0 \\
\hline Consumer Durabĩes & 9.4 & 9.1 & 8.4 & 7.6 & 0.1 & 8.0 \\
\hline Machinery \& Equipment & 6.2 & 6.5 & 7.6 & 6.6 & 7.1 & 6.9 \\
\hline Other Markets & 6.9 & 5.9 & 5.4 & 5.3 & 4.8 & 4.5 \\
\hline Statistical Adjustment & +0.1 & +1.6 & +1.0 & +0.1 & +0.5 & -0.3 \\
\hline Domestic, total & 95.3 & 93.6 & 93.1 & 91.8 & 93.4 & 94.6 \\
\hline Export & 4.7 & 6.4 & 6.9 & 8.2 & 6.6 & 5.4 \\
\hline Total $\%$ & 100.0 & 100.0 & 100.0 & 100.0 & 100.0 & 100.0 \\
\hline $\begin{array}{c}\text { Total Shipments (Thousand } \\
\text { Short. Tons) }\end{array}$ & 6,023 & 7,343 & 6,866 & 4,965 & 6,374 & 6,678 \\
\hline
\end{tabular}

$\%$ of Total Shipments *The data are published by the Aluminum Association. For 1976 ,
the revised data as reported in Aluminum Monthly, October 1978
is used in the table.

Source: Aluminum Statistical Review, 1976, for 1972 through 1975. Aluminum Monthly, October 1978, for 1976 and 1977. 
TABLE $3.3-10$

HISTORICAL AND PREDICTED APPARENT CONSUMPTION OF ALUMINUM METAL*. (Thousand Short Tons)

\begin{tabular}{|c|c|c|c|c|c|}
\hline Year & Primary & Secondary & Total & Ref. & Remarks \\
\hline 1972 & 4,676 & 250 & 4,926 & $(14)$ & \\
\hline 1973 & 5,560 & 265 & 5,825 & (14) & \\
\hline 1974 & 5,124 & 304 & 5,428 & (14) & \\
\hline 1975 & 3,570 & 337 & 3,907 & (14) & \\
\hline 1976 & 4,704 & 409 & 5,113 & (11) & \\
\hline 1977 & 4,937 & 502 & 5,439 & (13) & \\
\hline 1985 & 8,850 & 850 & 9,650 & (10) & \\
\hline 1987 & 9,200 & 900 & 10,100 & - & $\star \star$ \\
\hline 2000 & 15,800 & 2,000 & 17,800 & (10) & \\
\hline
\end{tabular}

\footnotetext{
*Apparent Consumption $=$ Apparent Supply - Recovery from Purchased New Scrap. The numbers for 1975 and 1976 in this table reflect the revisions made by the Bureau in Reference 8 . Secondary metal is the amount obtained from old scrap.

**Calculated by Arthur D. Little, Inc. based on the projections made by the Bureau for 1985 and 2000.
} 
- SIC 3351 Rolling, Drawing and Extruding of Copper - includes establishments primarily engaged in rolling, drawing and extruding copper, brass, bronze, and other copper-based alloy basic shapes, such as plate, sheet, strip, bar, and tubing. (Establishments primarily engaged in recovering copper and its alloy from scrap or dross are classified in industry 3341 .)

- SIC 3362 Brass, Bronze and Copper Foundries - includes establishments primarily engaged in casting of brass, bronze and copper-based alloys.

\subsubsection{Industry Structure}

Although significant transactions in copper concentrates or blister do take place, mined copper is generally processed to refined form for consumer use. Refined cupper is marketed in regular or standard shapes consisting largely of wire bars, cathodes, ingols and ingot bars, cakes, slabs, and billets. Market transactions in refined copper, therefore, define the relevant copper market for the industry as a whole.

The domestic copper industry is segmented into "primary" and "secondary" sectors on the basis of whether the copper product has originated from mined copper (virgin ore) or from scrap. By this definition, firms in the primary sector predominantly transform mined copper into refined copper; firms in the secondary sector either predominantly process scrap into secondary refined copper or prepare it for direct consumption in the form of unrefined copper scrap.

Production of refined copper in the United States from all sources is detailed in Table 3.4-1, for 1974, 1975, and 1976, based on data from the U. S. Bureau of Mines. Domestically mined copper constituted $74 \%$ of the total United States refined copper supply stream; refined copper from scrap, produced both by retineries and by "secondary plants" (i.e., numerous small smeliers of scrap copper), contributed another $20 \%$.

Production of refined copper in the United States by primary and secondary producers, 1950-1976, is given in 'l'able 3.4-2. Eistımated production of secondary reflned cupper by bull primary and secondary producers, 1960-1976, is given in Table 3.4-3. The 1974-1976 production of secondary copper in the United States which is recovered from purchased scrap is given in Table $3.4-4$.

\subsubsection{Primary Copper Industry}

The primary sector consists principally of 12 firms, vertically integrated to different degrees from mining to refining and semifabrication. Several independent mining firms are also included in the primary sector.

Mine production of copper was the principal product of nearly 200 mines in 1972. Most of the domestically mined copper is produced in five western states - Arizona, Utah, New Mexico, Montana and Nevada. Arizona, Utah and New Mexico together account for more than $80 \%$ of total U. S. mine production. Well over half (about 63\% in 1976) the total U. S. mine production of recoverable copper comes from Arizona.

Mills are almost always located close to the mines to minimize transportation costs. The value of the concentrates is high enough to allow some flexibility in smelter location. Most 
TABLE $3.4-1$

PRODUCTION OF REFINED COPPER BY SOURCE - 1974-1976*

$$
\text { (thousarids of short tons) }
$$

1974

Produced by
1975

Produced by:
1976

Produced by:

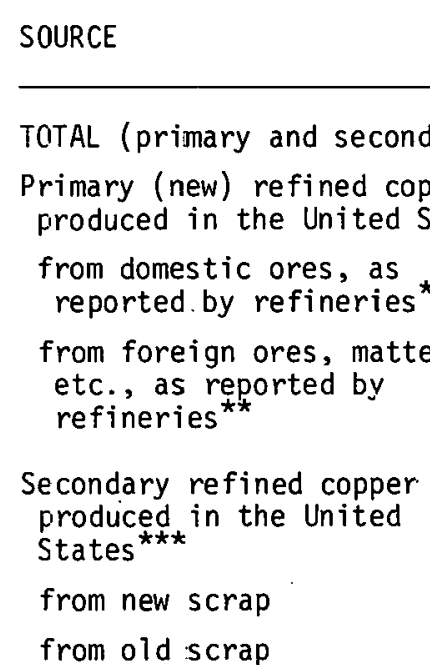

SOURCE

TOTAL

$2,151,566$

$1,654,658$

$1,420,905$

233,753

496,908

NA

NA

Refineries

$2,067,177$

$1,654,658$

$1,420,905$

233,753

412,519

ट29, 328

183,191
Seconcary

84,389

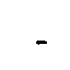

$-$

$1,286,189$

$1,286,189 \quad 1,286,189$

157,189

84,389

NA

NA
157,189

TOTAL

$\begin{array}{ll}1,787,864 & 1,71 \\ 1,443,378 & 1,44 \\ 1,286,189 & 1,28\end{array}$

344,486

344,486

NA

NA
270,880

139,230

131,650 secon:

Plants

73,606

$-$

- $\quad 1,420,603 \quad 1,420,603$

$-$

116,585

73,606

NA

NA
Secondary
Plants
$\star * \star \star *$

$8 \dot{5}, 794$

-

$-$

\section{NOTES AND SOURCES:}

*U.S. Bureau of Mines, Mineral Industry Surveys, "Copper in 1976" (Apri1 15, 1977), p.4.

** The separation of refined copper into meta" of domestic and foreign origin is only approximate, as accurate separation is not possible at this stage of processing.

Includes copper reported from foreign scrap.

${ }^{\star * * *}$ U.S. Bureau of Mines, 1974 Minerals Yearbook, Copper, Preprint, p. 29.

${ }^{\star \star \star \star \star *}$ U.S. Bureau of Mines, Mineral Industry Surveys, "Copper in December 1976" (March 10, 1977), p. 3.

NA: Not available on a consistent basis from public sources. 
TABLE 3.4-2

PRODUCTION OF REFINED COPPER BY

PRIMARY AND SECONDARY PRODUCERS, 1950-1976

(thousands of short tons)

\begin{tabular}{lccc} 
Year & $\begin{array}{c}\text { Total } \\
\text { Refined } \\
\text { Production }\end{array}$ & $\begin{array}{c}\text { Primary } \\
\text { Producer } \\
\text { Refined }\end{array}$ & $\begin{array}{c}\text { Secondary } \\
\text { Producer } \\
\text { Refined }\end{array}$ \\
\hline 1950 & 1446.4 & 1300.8 & 145.6 \\
1951 & 1362.5 & 1247.2 & 115.3 \\
1952 & 1320.5 & 1220.2 & 100.3 \\
1953 & 15014.0 & 1345.6 & 158.4 \\
1954 & 1418.4 & 1249.1 & 169.3 \\
1955 & 1562.8 & 1355.4 & 207.4 \\
1956 & 1687.8 & 1501.3 & 186.5 \\
1957 & 1616.1 & 1467.4 & 208.7 \\
1958 & 1579.5 & 1389.3 & 190.2 \\
1959 & 1331.5 & 1087.9 & 243.6 \\
1960 & 1794.6 & 1565.3 & 229.3 \\
1961 & 1813.9 & 1623.9 & 190.0 \\
1962 & 1884.5 & 1689.4 & 195.1 \\
1963 & 1884.4 & 1648.9 & 235.5 \\
1964 & 1990.4 & 1750.3 & 240.1 \\
1965 & 2214.8 & 1946.6 & 268.2 \\
1966 & 2183.3 & 1905.3 & 277.5 \\
1967 & 1526.6 & 1255.2 & 271.4 \\
1968 & 1839.0 & 1565.4 & 273.6 \\
1969 & 2214.9 & 1951.8 & 263.1 \\
1970 & 2242.7 & 1991.0 & 251.7 \\
1971 & 1962.4 & 1747.6 & 214.8 \\
1972 & 2258.5 & 2006.3 & 252.2 \\
1913 & 2312.6 & 1963.8 & 348.8 \\
1974 & 2151.6 & 1769.5 & 382.1 \\
1975 & 1775.0 & 1550.5 & 224.5 \\
1976 & 1995.0 & 1739.8 & 255.2
\end{tabular}

Source: Economic Impact of Environmental Regulations on the United States Copper Industry. January 1978, Table III-8.

Predicast Basebook, 1978. 
TABLE 3.4-3

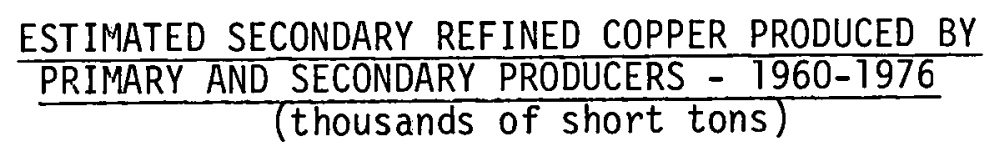

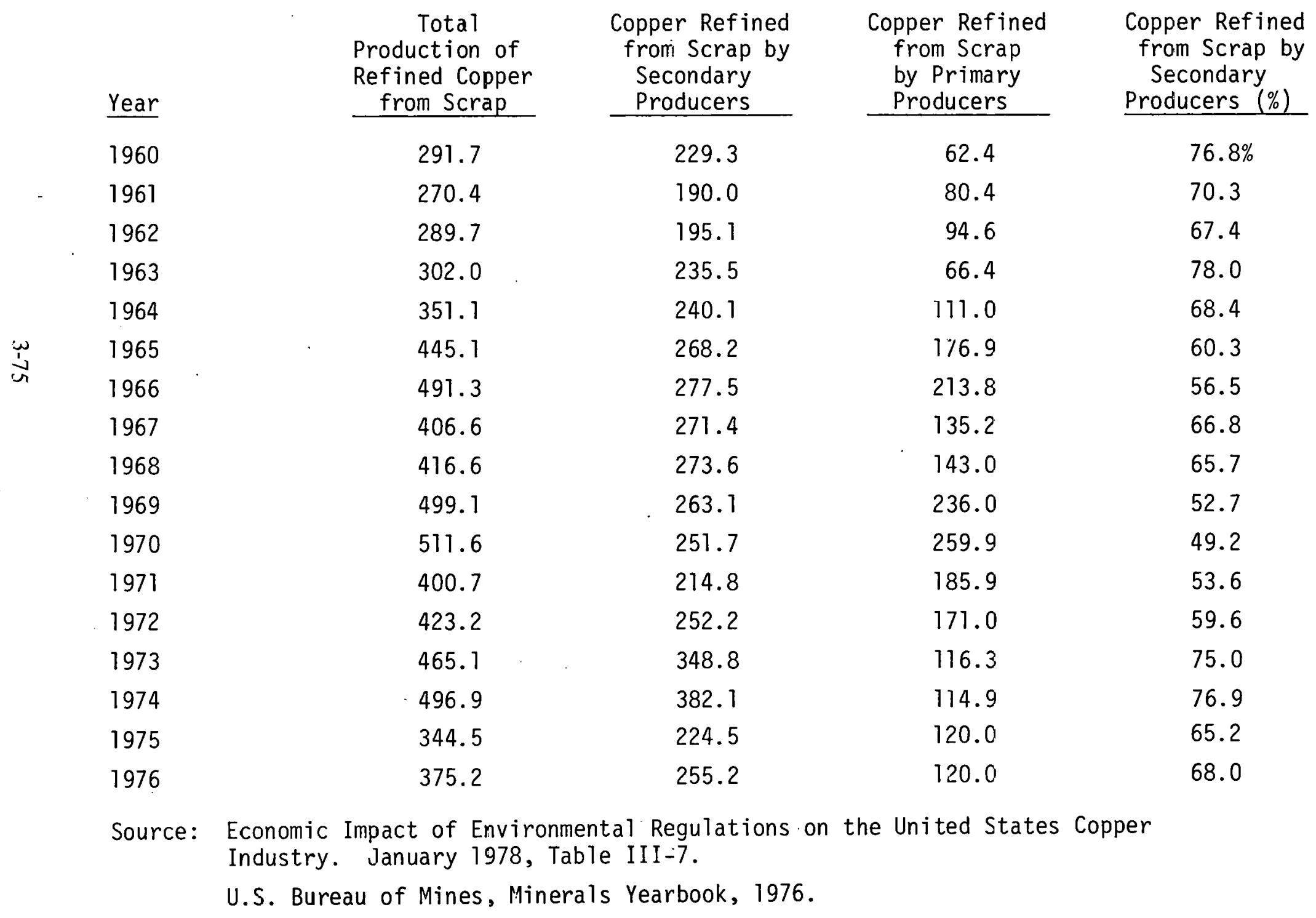


TAELE 3.4-4

PRODUCTION OF SECONDARY COPPER, REFINED AND UVREFINED

2ECOVERE[ FROM PURCHASED SCFAP, 1974-1976

(thousands of short tons of copper content)

\author{
$\underline{1977} \quad \underline{1975} \quad \underline{1976}$ \\ Total secondary copper prosused in the United States* \\ $1,344,320$ \\ $971,9651,106,000$ \\ recovered as unalloyed copper \\ $513,308 \quad 355,512 \quad 374,000$ \\ recovered as alloys** \\ 831,312 \\ 616,453 \\ 732,000 \\ Less: \\ Total refined copper froduced from scrap in the \\ United States*** \\ 496,308 \\ 344,486 \\ 374,480 \\ Equals: \\ Total secondary copper produced in the Urited \\ States which is used ifirectly \\ 847,712 \\ 627,479 \\ 731,520 \\ * U.S. Bureau of Mines, Mineral Inclustry Surveys, "Copper in 1976" (.7pri1 15, 1977), p. 4. \\ Includes copfer recovered from bath copper-base scrēp and other than copper-base scrap. \\ ** Includes copfer in chemicals as fallows: \\ 1974: $2, \mathrm{E} 49$ \\ 1975: 2,480 \\ 1976: $4,[07$ \\ U.S. Bureau of Mines, Ibid. \\ *** Refer to Table 3.4-1.
}


smelters are located near the mills that supply them or on tidewater or railhead in order to receive concentrates from distant mills. With the major copper mines centered in the western states, most of the smelting capacity is in that region. Refineries can be located anywhere between smelters and fabricators, since transportation costs for blister and refined copper are about the same.

The basic data on the primary producers, i.e., mine production of recoverable copper, and refinery capacity for the years 1974-1976 are given in Table 3.4-5.

\subsection{Industry Concentration}

The U.S. copper industry is highly concentrated. In 1974, four firms accounted for $64 \%$ of total U.S. mine production. Eight companies, including these four, accounted for $88 \%$ of the total. Seven firms together represent virtually all of the U.S. smelter and primary refinery capacity:

\subsection{Vertical Integration}

Several of the domestic primary producers participate either directly or through subsidiaries in all five stages of production: mining, milling, smelting, refining, and fabrication. Productive capacities, however, are not always matched between the different stages of production.

\subsubsection{Secondary Copper Industry}

In the secondary copper smelting and refining industry in the United States, there are approximately 50 producers of either brass and bronze ingots or secondary refined copper operating approximately 70 plants. The plants in this industry fall into two fairly distinct segments: (1) producers of brass and bronze ingots and (2) producers of unalloyed copper.

\subsection{Types of Firms}

Most of the firms in the secondary copper industry are small, individually owned operations having only one plant; only a few are publicly held. A minority of the firms (but still representing a large fraction of the production) are either subsidiary operations of large mining companies or are subsidiaries of conglomerates.

For the 1963-1972 period, the four largest firms accounted for about $40 \%$ of the value of shipments; the eight largest companies accounted for $69 \%$; the 20 largest, for about $85 \%$; and the 50 largest for almost all of the value of shipments.

\subsection{Types of Plants}

There are 63 plants in the brass and bronze ingot segment. These producers manufacture a wide variety of specification alloys. These alloys generally fit a series of specifications that have been outlined by both ASTM and the Brass and Bronze Ingot institute (BBII) and are in the form of 30 -pound hrass or bronze ingots. Some of the smelters also produce a series of materials in the form of shot that are sold to factories for the inoculation of gray iron. The shot may be pure copper or copper-nickel alloys of various types.

The plants are usually small, with production ranging from 500-1500 short tons per month and employment ranging from 10-500 people. The facilities vary in age; some plants are $40-50$ 
TABLE $3.4-5$

BASIC DATA ON PRIMARY PRODUCERS OF COPPER 1974-1976

$\underline{1974} \quad \underline{1975} \quad \underline{1976}$

$\begin{array}{llll}\begin{array}{l}\text { Mine Production of Recoverable } \\ \text { Copper (short tons) }\end{array} & 1,597,002 & 1,413,366 & 1,605,586 \\ & & & \\ \begin{array}{l}\text { Refinery Capacity* } \\ \text { (annual short tons) }\end{array} & 2,848,000 & 2,907,000 & 2,739,000\end{array}$

* Capacity includes that for processing scrap.

Souree: U.S. Dureau of Mines, Mineral Industry Surveys, "Copper in 1974" and "Copper in 1976."

American Bureau of Metal Statistics, Inc., Nonferrous Metal Data for 1974, 1975, and 1976 . 
years old, with additions and renovations made over the years. Several of these plants are diversified, being involved as well in other secondary metal processing operations, such as secondary aluminum, lead, and zinc. In the normal sense of production, however, the secondary brass and bronze ingot-making segment of the industry is non-integrated. None of the smaller smelters is integrated to the point of producing a finished or semi-finished product.

There are seven producers of unalloyed copper, which may be in the form of blister copper, fire-refined copper, cathode copper, wire bar, continuous cast, or a finished product, depending on both the production scheme and the needs of the customer. Also, several precious metals are usually recovered as a result of electrorefining to produce cathode copper.

Plant sizes range from 1500-18,000 short tons production per month; the work force ranges from 100-1800 people. Although the facilities are 40-50 years old, they generally utilize sophisticated technology and equipment and are integrated toward producing finished products, such as tubes and rods. Many of the firms are completely integrated, using copper scrap as a raw material and turning out a finished product, such as electrical wire, valve fittings, and copper tubing.

Producers of brass and bronze ingots are located mostly in the northeastern, Pacific Coast, and east north central states. Producers of unalloyed copper are also located in heavily industrialized areas, mostly in the northeastern states, with one plant in the south and two in Illinois.

\subsection{Percent of Industry Represented by Each Segment}

Segment 1 (brass and bronze ingots) represents $53 \%$ of the plants in the secondary copper smelting and refining industry, $46 \%$ of the employees, and $32 \%$ of the production. Segment 2 (unalloyed copper) contains only $10 \%$ of the plants in the industry, but accounts for about $65 \%$ of the production, and $44 \%$ of the employment.

\subsubsection{Process Technology}

\subsubsection{Primary Copper Industry}

Production of primary copper involves four basic activities: mining, milling, smelting, and refining. Refined copper is then fabricated for various end-use markets. The four st.ages of primary production are:

- Mining - where ore containing approximately $0.4-2 \%$ copper is mined;

- Milling - where the copper-containing minerals arc separated from waste rock to produce a concentrate containing about $25 \%$ copper;

- Smelting - where concentrates are melted and reacted to produce $98 \%$ pure "blister" copper; and

- Refining - where blister copper is refined electrolytically to produce $99.9 \%$ pure cathode copper. Some of the new hydrometallurgical processes combine the functions performed by smelting and refining.

A generalized flowsheet for copper extraction from sulfide ores is shown in Figure 3.4-1. 


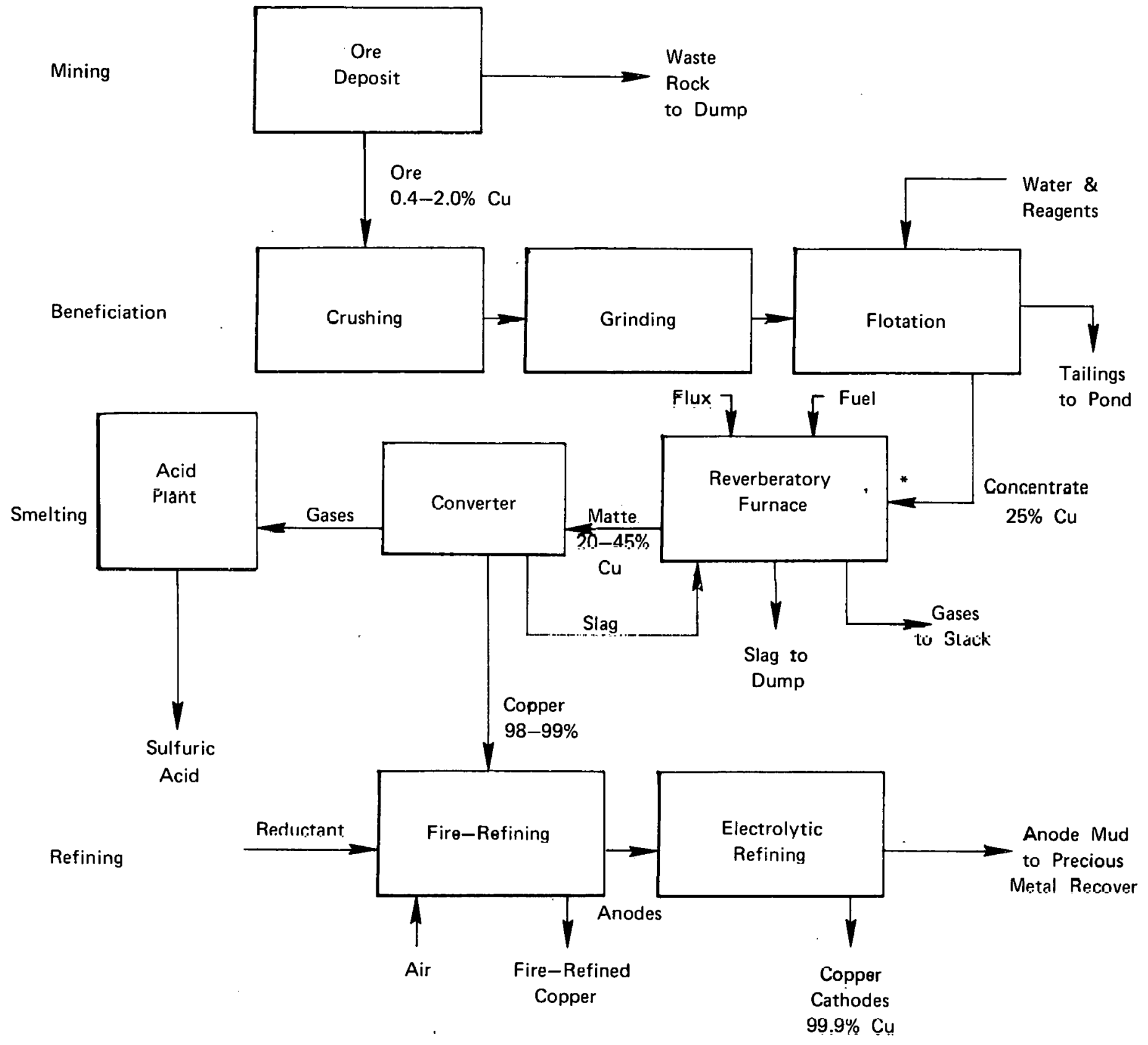

* Optional roasting step not shown

t.:

FIGURE 3.4-1 GENERALIZED FLOWSHEET FOR COPPER EXTRACTION FROM SULFIDE ORES 


\subsection{Mining and Beneficiation}

Alvout $85 \%$ of the copper ore mined comes from open pits, and the rest from underground mines. Underground mining methods for copper ores involve caving and/or cut-and-fill mining.

From a processing viewpoint, copper ores can be classified in three categories - sulfide, native copper, and oxide. Each category requires different beneficiation processes. The sulfide ores are treated primarily by crushing, grinding, and froth flotation to produce a concentrate (or several concentrates) of sulfide minerals; worthless "gangue" is rejected as tailings. Generally, only sulfide ores are amenable to concentration procedures. The output of this beneficiation process, concentrates, may contain $11-32 \%$ copper.

In native copper ores the copper occurs in metallic form. The Lake Superior district in Michigan is the only major source of ore of this type. Although the reserves of this ore are extensive, they contribute only a small portion of the total U.S. mine production of copper.

Oxide ores are treated primarily by leaching with dilute sulfuric acid. Copper is recovered in metallic form from leach solution by precipitation on iron scrap (cementation) or by electrowinning from the solution.

\subsection{Smelting}

Because most U.S. copper is extracted from low-grade sulfide ores that require concentration, current pyrometallurgical practice for recovery of copper is fairly uniform from smelter to smelter and is adapted to treating fine-grained sulfide concentrates consisting mainly of copper and iron sulfides and gangue. Copper's strong affinity for sulfur and its weak affinity for oxygen compared with that of iron and other base metals in the ore are the basis for the three major steps in producing copper metal from sulfide concentrates: roasting, smelting, and converting.

About half the copper smelters in the U.S. roast their charge prior to feeding the smelting furnace. The older smelters use multiple-hearth roasters for this purpose while the new smelters use fluidized bed roasters.

Roasted or unroasted dried concentrates are smelted in a smelting furnace. The reverberatory furnace (reverb) is the traditional smelting furnace used in the United States. The charge is heated by burning fuel in the furnace cavity. Most of the reverbs in the U.S. use natural gas, fuel oil, or powdered coal, as a fuel. In newer smelting processes, the heat required for smelting is supplied by the oxidation of a portion of the charge or by electric resistance heating of the slag.

In the smelting furnace, copper and sulfur form the stable copper sulfide, $\mathrm{Cu}_{2} \mathrm{~S}$. Excess sulfur unites with iron to form a stable ferrous sulfide, FeS. The combination of the two sulfides, known as matte, collects in the lower area of the furnace and is removed. Such mattes may contain from $15-50 \%$ copper, with a $40-45 \%$ copper content being most common, and they may also contain impurities such as sulfur, antimony, arsenic, iron, and precious metals.

The remainder of the molten mass containing most of the other impurities and known as slag floats on top of the matte, being of lower specific gravity, and is drawn off. Reverb and electric furnace slags are discarded, while slags from other types of smelting furnaces are treated by milling/froth flotation or in an electric furnacc for coppcr rccovery. The copper contained in the discard slag is a major cause of copper loss in pyrometallurgical practice. 
Matte produced in the reverberatory furnace is transferred to the converters in order to convert it to blister copper. Air is blown through the matte, to oxidize the $\mathrm{FeS}$ to $\mathrm{FeO}$ and $\mathrm{Fe}_{3} \mathrm{O}_{4}$ and remove sulfur with the off-gases as $\mathrm{SO}_{2}$. Silica flux is added to the converter to form a fluid iron silicate slag. When all the iron is oxidized, the slag is skimmed from the furnace leaving behind "white metal" or molten $\mathrm{Cu}_{2} \mathrm{~S}$. This white metal is then oxidized to blister copper. The blister copper is removed from the converter and cast or subjected to additional fire refining prior to casting.

\subsection{Refining}

The blister copper produced by smelting is too impure for most applications and must be refined before use. It may contain silver and gold as well as such other elements as arsenic, antimony, bismuth, lead, selenium, tellurium, and iron. Two methods are used for refining copper-fire refining and electrolysis.

The fire-refining process employs oxidation, fluxing and reduction. The molten metal is agitated with compressed air; sulfur dioxide is liberated, and some of the impurities form metallic oxıdes, which combine with added silica to form a slag. After this's slag has been skimmed off, copper oxide in the melt is reduced by inserting green-wood poles or gaseous reductants below the bath surface. If the original material does not contain sufficient gold or silver to warrant its recovery, or if a special-purpose copper-containing silver is desired, the fire-refined copper is cast directly into forms. If it is of such a nature as to warrant the recovery of precious metals, fire refining is carried out only to insure homogeneous anodes for subsequent electrolytic refining.

A major portion of U.S. blister output is electrolytically refined. In electrolytic refining, blister copper, cast in anode shape, and cathodes (thin copper sheets prepared separately) are hung alternately in plastic-lined or lead-lined concrete electrolytic cells that contain the electrolyte-essentially a solution of copper sulfate and sulfuric acid. When current is applied, copper is dissolved from the anode and an equivalent amount of copper plates out of solution on the cathode. Such impurities as gold, silver, platinum-group metals, and the selenides and tellurides fall to the bottom of the tank and form anode slime or mud. Arsenic, antimony, bismuth, and nickel enter the electrolyte. The electrolyte has to be treated to prevent the buildup of these impurities, which would have a deleterious effect on cathode purity. After the plating cycle is finished, the cathodes are removed from the tanks, melted, and cast into commercial refinery shapes. Anode scrap is remelted to form fresh anodes. The copper produced has a minimum purity of $99.9 \%$.

\subsection{Hydrometallurgy of Oxides}

$\Lambda$ bout $10-15 \%$ of U.S. copper production comes from oxide sources. 'I'he hydrometallurgical treatmont of cuoh oroe with dilute sulfuric acid to dissolve the container copper is an old established technology. Since surplus sulfuric acid is available near the mines as a result of pollution control measures at smelters, acid leaching of mine waste dumps and mill tailings is widely practiced, as well as leaching of oxide ores mined specifically for this purpose. Since many of these materials contain limestone, such a leaching process indirectly disposes the acid by neutralization.

Once in solution, copper is recovered either by precipitating on iron scrap or via LIX (liquid ion exchange) and electrowinning. Precipitated copper or cement is usually shipped to a smelter for processing. 


\subsubsection{Secondary Copper Industry}

\subsection{Raw Materials}

The basic raw material of the secondary copper industry is copper and copper-based alloy scrap. About two-thirds of the amount of secondary copper recovered is in the form of either brass or bronze, while one-third is in the form of unalloyed copper.

Copper sold to manufacturers is returned to the producers either as new scrap or old scrap. New scrap is returned directly from the manufacturers or via collectors and scrap brokers. Old scrap is returned from consumers of copper. Purchased scrap may move from one location to another within the same company, or from one company to another.

\subsection{Sorting Scrap}

Sorting scrap according to the classification shown in Table 3.4-6 is one of the most important steps in raw material preparation for the ultimate recovery of secondary copper. Small scrap yards usually segregate scrap to a few basic types, but larger yards find it practicable to segregate their scrap completely, according to all of the common grade specifications. Several methods have been developed for determining the approximate compositions of the thousands of items that pass through the scrapyards. The complexity of the tests ranges from simple recognition of known compositions to chemical analyses. The simplest method of segregating scrap is by recognition of its source or previous use, for example, copper wire, radiator fins, brass fittings, etc.

\subsection{Scrap Preparation}

Before the scrap metal is blended in a furnace to produce the desired ingots, the raw material must be sampled. Removal of some of the non-metallic contaminants or, in some instances, preprocessing the raw material to permit more efficient and economical utilization of the scrap may be desirable. These processes may be either mechanical, pyrometallurgical, or hydrometallurgical.

Many types of scrap are prepared for smelting or melting by mechanical methods. Insulation and lead sheathing are removed from electrical conductors by special stripping machines. Wire, thin-plate, and wire-screen scraps are usually compressed into briquettes, bales, or bundles. Large, solid items are reduced in size by pneumatic cutters, electric shearing machines, or manual sledging. Brittle springy turnings, or borings, and long chips are crushed in hammer mills or ball mills. Slags, drosses, skimmings, foundry ashes, spills, and sweepings are ground to liberate prills or other metallics from the gangue so that they can be recovered by gravity concentration or other physical means. Small-size materials, such as drillings, clippings, and crushed turnings, are often run over a magnetic separator to remove tramp iron.

Many types of scrap must be given a preliminary furnace treatment before actual melting and refining operations begin. Oil and other organic impurities and moisture are removed by heating in muffle furnaces or kilns. Scrap, such as journal bearings, lcad-sheathed cable, and radiators, can be sweated to remove low melting point components, such as babbitt, lead, and solder as valuable byproducts which would otherwise contaminate a melt. Sweating is performed in a conventional sloping-hearth, gas-fired furnace or in a rotary kiln. The process can be a continuous or batch operation. 
No. 1 Copper Wire

2 No. 2 Copper Wire

No. 1 Heavy Copper

Mixed Heavy Copper

Light Copper

Composition or Red Brass

Red Brass Ccmposition Turnings

8 Genuine Babtitt-Lined Brass Bushings

9 High-Grade, Low Lead Eronze Solids

10 Bronze Pape-mill Wire Cloth

11 High-Lead Bronze Solids and Borings

12 Machinery or Hard Red Brass Solids

13 Urilined Sta:dard Red Car Boxes (Clean Jourials)

14 Lined Stand $\equiv$ rd Red Car Boxes (Lined Journal)

15 Cacks and Faucets

$\underset{\substack{\infty \\ \infty}}{\infty}$

16 Mixed Brass Screens

17 Yellow Brass Scrap

18 Yellow Brass Castings

19 01d Rolled Brass

20 New Brass Clippings

21 Brass Shell Cases without Primers

22 Brass She11 Cases with Primers

23 Small Brass Arms and Rifle Shells, zlean Fires

24 Small Brass Arms and Rifle Shells, zlean Muffled (Popped)

25 Yellow Brass Frimer

26 Brass Pipe

27 Yellow Brass Fiod Turnings
28 Yellow Brass Rod Ends

29 Yellow Brass Turnings

30 Mixed Unsweated Auto Fiadiators

31 Admiralty Brass Zonderser Tubes

32 Aluminum Brass Condenser Tubes

33 Muntz Metal Tubes

34 Plated Rolled Brass

35 Manganese Bronze Solids

36 New Cupro-Nickel Clippings and Solids

37 0ld Cupro-Nickel Solids

38 Soldered Cupro-Nickel Solids

39 Cupro-Nickel Turnings and Borings

40 Miscell laneous Nickel Copper and NickelCopper-Iron Scrap

New Monel Clippings and Solids

42 Monel Rods and Forgings

43 01d Monel Sheet and Solids

44 Soldered Monel Sheet and Solids

45 Soldered Monel Wire, Screen and Cloth

46 New Monel Wire, Screen and Cloth

47 Monel Castincs

48 Monel Turninçs and Borings

49 Mixed Nickel Silver Clippings

50 New Nickel Silver Clippings and Solids

51 New Segregated Nickel Silver Clippings

52 0ld Nickel Silver

53 Nickel Silver Castings

54 Nickel Silver Turnings 
The blast furnace is used extensively in secondary smelters for smelting low-grade copper and brass scraps, refinery slags, drosses, and skimmings to produce black copper $(80-90 \% \mathrm{Cu})$. The conventional secondary copper blast furnace is a top-charged, bottom-tapped shaft furnace heated by coke burning in a blast of air introduced through tuyeres placed symmetrically around the bottom of the shaft.

The black copper $(80-90 \% \mathrm{Cu})$ produced in the blast furnace is converted to blister copper by blowing air into the molten charge. In contrast to the converting operation in a primary copper smelter where two blowing stages are needed, only the second stage, or "blister" blow, is required in secondary copper converting.

Copper-rich metallics are also separated by gravity. This technique involves grinding, screening, and gravity separation in a water medium. Although the total loss of metal is often greater than in the blast furnace, gravity separation is well adapted to fines that might be blown out of the furnace.

\subsection{Melting and Alloying Intermediate Grade Copper Scrap}

About two-thirds of the secondary copper production in the United States is used in ingot plants and foundries to make brass and bronze alloys by simple melting and refining methods. The amount of refining is usually small if the scrap is well sorted so that impurities or excess alloy constituents can be diluted to composition specifications with high-grade scrap or virgin metals. These conditions are not easily maintained, however, because certain impurities, such as aluminum and silicon, have exceedingly low permissible limits in the product. Both aluminum and silicon are difficult to remove by refining. Impurities such as iron, sulfur, cadmium, bismuth, zinc, phosphorus, and manganese are not as difficult to remove by common refining techniques.

Melting, refining, and alloying procedures are essentially the same for reverberatory, rotary or crucible furnaces. Capacities of stationary reverberatory furnaces used in secondary smelters range from a few thousand pounds to 100 short tons or more. The side- or end-charged arched-roof tapping furnace is the type most extensively used. Reverberatory furnace slags usually contain metal values that can be recovered in the blast furnace. Slags produced by small secondary plants are frequently sold to primary smelters on the basis of copper content only. Some plants grind the slag and recover metallic constituents in milling operations before the slag is sold.

The rotary furnace is designed to provide efficient melting and refining and convenient pouring of fairly large melts. Furnace capacity ranges from several short tons to 50 or more short tons of nonferrrous metals. It may have a particular advantage over stationary furnaces for melting loose or baled light scrap, because the rotary mixing action promotes better heat transfer to the melt and causes a more rapid coalescence of melted globules.

A fairly large tonnage of secondary copper is produced in crucible furnaces, heated by gas, oil, coke or electricity. The once popular, coke-fired pit furnace is seldom used today. Crucible furnaces are used in the secondary-copper industry for melting clean, well-segregated scrap mostly in foundries. Very little fire-refining is performed in crucibles.

The stationary reverberatory is the most practicable furnace for making very large tonnages

of standard alloys from scrap. The rotary furnace is more flexible than the reverberatory, but the 
capacity is limited to moderate tonnages. Tilting and stationary crucible furnaces, either gas or electric, are used to advantage for making small melts of special alloys. Electric induction furnaces are increasing in popularity at ingot plants and foundries where special high-grade alloys are made. The advantages of electric furnaces include higher melting speed and precise temperature control, which help to defray the relatively higher cost of electrical equipment.

Melting furnaces are always associated with other equipment designed to receive the melt. Melts are usually tapped from furnaces into feeder ladles, which transport the metal to a mold line for making conventional ingots. The mold line is a series of ingot molds placed on a rack that may be stationary or movable. If stationary, the molds are filled with metal poured from a portable ladle.

$\Lambda \mathrm{n}$ automatic mold line is an endless mold-conveying system in line with, or on the periphery of, a large circular rack known as a casting wheel.

Melting and refining furnaces are operated frequently in conjunction with a plant or mill to produce items such as rods, tubes, sheet, and similar products. In this case, the furnaces are tapped into special billet molds to make shapes for subsequent milling operations.

\subsection{Refining High-Grade Copper Scrap}

The refining furnace is either a stationary reverberatory or cylindrical tilting type with a capacity of 20 to 300 short tons. Full fire refining is often required to produce billets, slabs, cakes and bars for manufacturing plates, sheets, rods, and so forth. The fire-refining procedure is identical to that used in the primary industry. The electrolytic copper refining is also similar to that in the primary industry, described earlier.

\subsubsection{Materials Flow}

\subsubsection{General}

The flow of copper in the copper industry in the United States for 1976 is shown in simplified form in Figure 3.4-2. The two major sources of copper supply are domestic and imported ore and copper-based scrap.

The following observations of the flow of copper in 1976 can be made:

- Refined copper accounted for $73.4 \%$ of the total copper supply of the United States; and

- Semifabricators and end users utilized $50 \%$ of the recovered scrap directly, without further refining; the remainder was smelted and refined.

\subsubsection{Classification of Recoverable Materials}

Both the secondary copper industry and the American Socicty for Testing Materials have made a continuing effort over the past 35 years or so to reduce the number of varieties of copperbased alloys. At one time, more than 500 commercial copper-based alloys were made in the United States. Sorting and grading mixed scrap with no uniform standards was a major problem in the industry. Of the many hundreds of copper-based alloys that become available for reuse through scrap recovery channels, 54 primary types are now included in the standards published by the National Association of Recycling Industries (NARI, previously NASMI). These are listed in Tablc 3.4-6. 


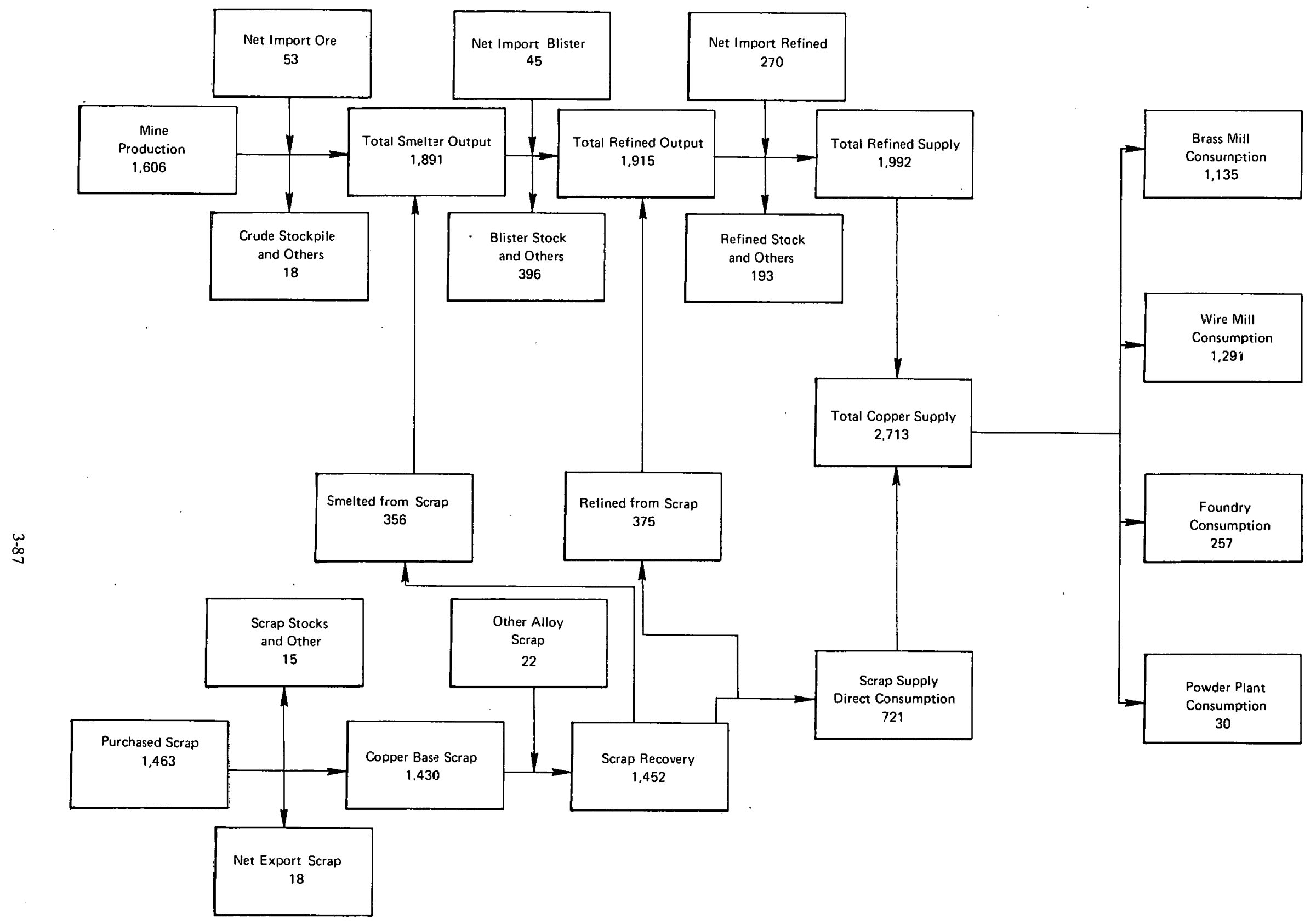

Sources: U.S.B.M. Minerals Industry Surveys, Copper Industry in Dec. 1977.

U.S.B.M. Minerals Industry Surveys, Copper in, 1977.

Arthur D. Li:tle, Inc., estimates. 
Briefly, this copper-bearing scrap can be summarized as follows:

No. 1 copper: Scrap from unalloyed copper, clean and free of contaminants. It must not be less than $1 / 16$ inch thick or below No. 16 B\&S wire gauge. Included in this category are wire and cable (excluding burnt. wire), copper clippings, punchings, busbars, commutator segments, and copper tubing.

No. 2 copper: Miscellaneous unalloyed copper scrap having a nominal $96 \%$ copper content (minimum $94 \%$ ).

Light copper: Miscellaneous unalloyed copper scrap having a nominal $92 \%$ copper content (minimum $88 \%$ ), such as shect coppcr, guttcrs, downspouts, kettles, boilers, and similar scrap.

Kefinery brass: Scrap containing a minimum of $61.3 \%$ copper and a maximum of $5 \%$ iron. Included are brass and bronze solids, turnings; and alloyod and contaminatcd copper scrap.

Copper-bearing scrap: Miscellaneous copper-containing skimmings, grindings, ashes, iron-containing brass, and copper residues and slags.

Brass and Bronze scrap: This category is usually kept segregated by the type of alloy in a large number of categories, such as red brass; high-grade, low-lead bronze solids; high-lead bronze solids and borings; yellow brass scrap; yellow brass castings; new brass clippings; mixed nickel silver clippings; manganese bronze solids; and the like.

\subsubsection{Recycling Profile}

The main consumers of copper and copper-based alloy scrap are smelter/refineries, ingot manufacturers, and brass and bronze mills. Refiners use hoth lnw-grade and high-grade scrap as raw material. Higher grades of scrap are introduced in the later stages of processing. For example, No. 2 copper is generally introduced at the anode melting step before electrorefining and No. 1 copper at the cathode melting step. The cathodes are melted and cast into refinery shapes. Brass and bronze ingot-makers make casting alloy ingots mainly from brass and bronze scrap supplemented by other materials such as No. 1 and No. 2 copper scrap. small amounts of refined copper, and alloying additives such as tin and zinc. Brass mills make wrought alloys that are then fabricated to finished mill products, such as sheets, tubes, rods, and pipe. Brass mills use purchased brass and bronze scrap and No. 1 and No. 2 copper scrap, along with significant quantities of home-generated scrap, refined copper, and such alloying additives as slab zinc, lead, tin, and nickel, as shown in Table 3.4-7.

In 1976 primary and secondary copper producers consumed 767,000 short tons of scrap, as shown in Table 3.4-7. Of this, No. 1 copper made up about 19\%, No. 2 mixed heavy and light accounted for $24 \%$; low-grade scrap and residues accounted for $33 \%$; and brass and bronze scrap, including auto radiators, made up the remaining $24 \%$. Old scrap made up $59 \%$ of the total.

In order to estimate the total amount of copper-based scrap available for recycling in 1976, a 1969 Báttelle estimate ${ }^{(1)}$ has been updated. The estimate of copper scrap recycled in 1969 was 


\section{PURCHASED COPPER-BASE SCRAP CONSUMED - 1976*}

Class of Consumer and Scrap Item

Secondary Copper Smelters

No. 1 wire and heavy

No. 2 wire, mixed heavy and light

Composition or soft red brass

Railroad-car boxes

Yellow brass

Cartridge cases

Auto radiators (unsweated)

Bronze

Nickel, silver and cupronickel

Low brass

Aluminum bronze

Low-grade scrap and residues

TOTAL

Primary Producers

No. 1 wire and heavy

No. 2 wire, mixed heavy and light

Refinery brass

Low-grade scrap and residues

TOTAL

Brass Mills

No. 1 wire and heavy

No. 2 wire, mixed heavy and light

Yellow brass

Cartridge cases and brass

Bronze

Nickel, silver and cupronickel

Low brass

Aluminum bronze

TOTAL

TOTAL ALL PRODUCERS

\author{
Consumption \\ (000 Short Tons)
}

25.0

58.0

58.0

2.0

46.0

49.0

20.0

3.0

2.0

77.0

340.0

118.0

129.0

4.0

176.0

427.0

156.0

73.0

272.0

78.0

4.0

29.0

46.0

$-$

658.0

1425.0 01d Scrap

New Scrap

$\%$

87.5

72.3

77.1

100.0

88.9

100.0

100.0

82.9

89.7

33.2

23.8

16.9

68.5

48.0

27.5

50.4

72.9

52.0

52.0

72.5

49.6

27.1

48.0

27.7

22.9

11.1

0

17.1

10.3

66.8

76.2

83.1

31.5

82.3

97.4

100.0

100.0

100.0

100.0

100.0

100.0

96.5

4.5

34.0

66.0

* Total figures for three classes of consumer and figures for breakdown by type of scrap for brass mills based on 1976 Bureau of Mines data. Figures for breakdown by type of scrap for secondary copper smelters and primary producers are Arthur D. Little estimates based on 1974 data in U.S. Bureau of Mines Minerals Yearbook chapter dealing with copper. 
based on estimates of the life cycles for the various products providing copper scrap. Another assumption in the Battelle study is that new, or industrial scrap is $100 \%$ recycled. Our estimate of the amount of scrap available for recycling in 1976 is given in Table 3.4-8, which shows that approximately half of the scrap available was recycled in 1976, and that the major source of copper available but not recycled was low-grade scrap and residues. This study has used the Battelle estimates with minor adjustments based on the positive trends toward recycling in the 1970's. Consequently, we have not taken into consideration the.time lag in the Battelle study, i.e., we have not estimated the consumption of copper at the beginning of the various life cycles to derive the actual supply in 1976. The estimates of the amounts of various forms of copper scrap available for recycling should therefore only be taken as order-of-magnitude figures since any copper that remains in productive use beyond the average life cycle will be available in the future and not necessarily lost. Another fact that should be observed is that during a year with low scrap consumption, e.g., 1976, certain types of copper scrap may be stockpiled.

Using the life cycle method of estimating available supply results in inaccurate figures for certain forms of scrap during such low demand periods. This would be particularly true for No. 1 and No. 2 wire which are almost $100 \%$ recycled.

\subsubsection{Future Trends}

\subsubsection{Technological Trends}

The only significant technological trend foreseen for the near future is the change-over in the primary industry from reverberatory smelting to newer smelting processes such as flash smelting, electric smelting, the Noranda, Outokumpu and Mitsubishi processes. This change-over is necessitated by pressure to meet ambient air quality standards. Given the present state of the copper industry, and the fact that there are no firm plans for any new smelter construction in the United States, we do not expect any new smelters to come on-stream until 1985. Furthermore, since the industry seems to be favoring flash smelting rather than electric smelting, technological trends should have no impact on the 1987 recycling target.

\subsubsection{Industry Structure Trends}

Some of the larger oil companies are now investing in the primary copper industry. We do not believe, however, that this change in ownership will have any significant impact on either total industry capacity or the relation between primary and secondary segments of the industry. Consequently, we do not believe that the industry structure will have any impact on the 1987 recycling target.

\subsubsection{Industry Growth}

The output of primary refined copper is expected to be $2,010,400$ short tons by 1987 . This estimate is based on a 1974 production level of 1,654,658 short tons and an Arthur D. Little, Inc. projected growth rate of $21.5 \%$ or $1.5 \%$ annually. 
TABLE $3.4-8$

\section{EST IMATED COPPER SCRAP AVAILABLE FOR RECYCLING - 1976}

Scrap Item

No. 1 Wire and Heavy

No. 2 Wire Heavy and Light

Composition, Red Brass

Railroac: Car Boxes

Yellow E.rass

Cartridge Cases

Auto Raciators

Bronze

Nickel, Silver, Coppernickel

Low Brass

Refinery Brass

Low Grace Scrap, Residues

TOTAL

\begin{tabular}{cc} 
& Recycled Copper** \\
Scrap as \% of \\
Recycled* & Copper Scrap \\
Copper Scrap & Available for \\
(000 Short Tons) & Recycling \\
\hline
\end{tabular}

299

260

58

2

318

78

49

24

32

48

4

1425

\section{6}

87.

36

100

77

63

92

38

81

95

38

19

49

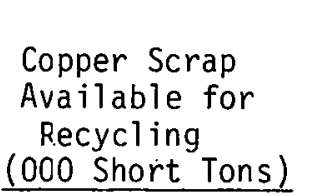

348

299

161

2

413

124

53

63

40

51

11

1332

2897
Not Recycled

Copper Scrap

as \% of Copper Not Recycled

Scrap Available Copper Scrap

for Recycling (000 Short Tons)

\section{9}

39

103$$
-
$$

95

46

4

$-39$

8

3

7

1079

1472

* Refer to Table 3.4-7.

** Estimation based on Battelle study "A Study to Identify Opportunities for Increased Solic Waste Utilization", 1972. 


\section{$3.5 \mathrm{ZINC}$}

\subsubsection{Industry Definition}

The zinc industry under the SIC 33 code system includes the following:

- SIC 3333 - Primary Smelting and Refining of Zinc - establishments primarily engaged in smelting zinc from the ore and in refining zinc by any process. Establishments primarily engaged in rolling, drawing, or extruding zinc are classified in industry 3356 .

- SIC 33414 - Secondary Smelting and Refining of Zinc - establishments primarily engaged in smelting zinc from scrap materials by any process.

- SIC 33691 - Zinc l'oundries - establishments primarily engaged in manufacturing castings and die castings.

Of the above SIC classifications, the primary (3333) and secondary (33414) smelters are producers of zinc metal. 'I'he zinc foundries (33691) do not produce any metal, but cast the metal into more useful forms. Zinc metal enters the manufacturing field in four major areas: galvanizing, brass and bronze products, castings, and rolled zinc. In addition to metallic applications, significant quantities of zinc are consumed as pigments or other chemicals.

\subsubsection{Industry Structure}

About $85 \%$ of the zinc smelting capacity in the United States is concentrated in six large plants. Table 3.5-1 details the company, location, production method, rated capacity, and age for all smelters in operation in 1976. All of the plants are fairly large, with the smallest plant accounting for almost $10 \%$ of the total capacity and the largest for about $29 \%$.

The owners of the zinc smelters are large corporations with diverse interests in other aspects of zinc production and outside the zinc industry. Five of the six owned mines that produced $75 \%$ of the domestic zinc concentrates, and refineries that produced $90 \%$ of the domestic primary slab zinc. Examples of corporations that have interests outside of the zinc industry include:

- ASARCO and AMAX Inc., diversified corporations that mine and smelt many metals.

- Gulf Resources and Chemical Corporation, the owner of Bunker Hill Company.

- Engelhard Minerals and Chemical Corporation, the owner of National Zinc Company.

- Gulf and Western Industries, the owner of New Jersey Zinc Company.

- St. Joe Minerals Corporation, the owner of St. Joe Zinc Company.

The total primary zinc capacity in the United States is 653,000 short tons of zinc slab per year.

The secondary zinc smelting industry, with about $15 \%$ of U.S. capacity is composed of a comparatively large number of smaller operations. Table 3.5-2 shows a sample of secondary smelters in the United States. These companies buy scrap from 3000 independent dealers and processors who collect, sort, store, and ship scrap to the smelters. 
TABLE 3.5-1

PRIMARY ZINC SMELTERS - 1976

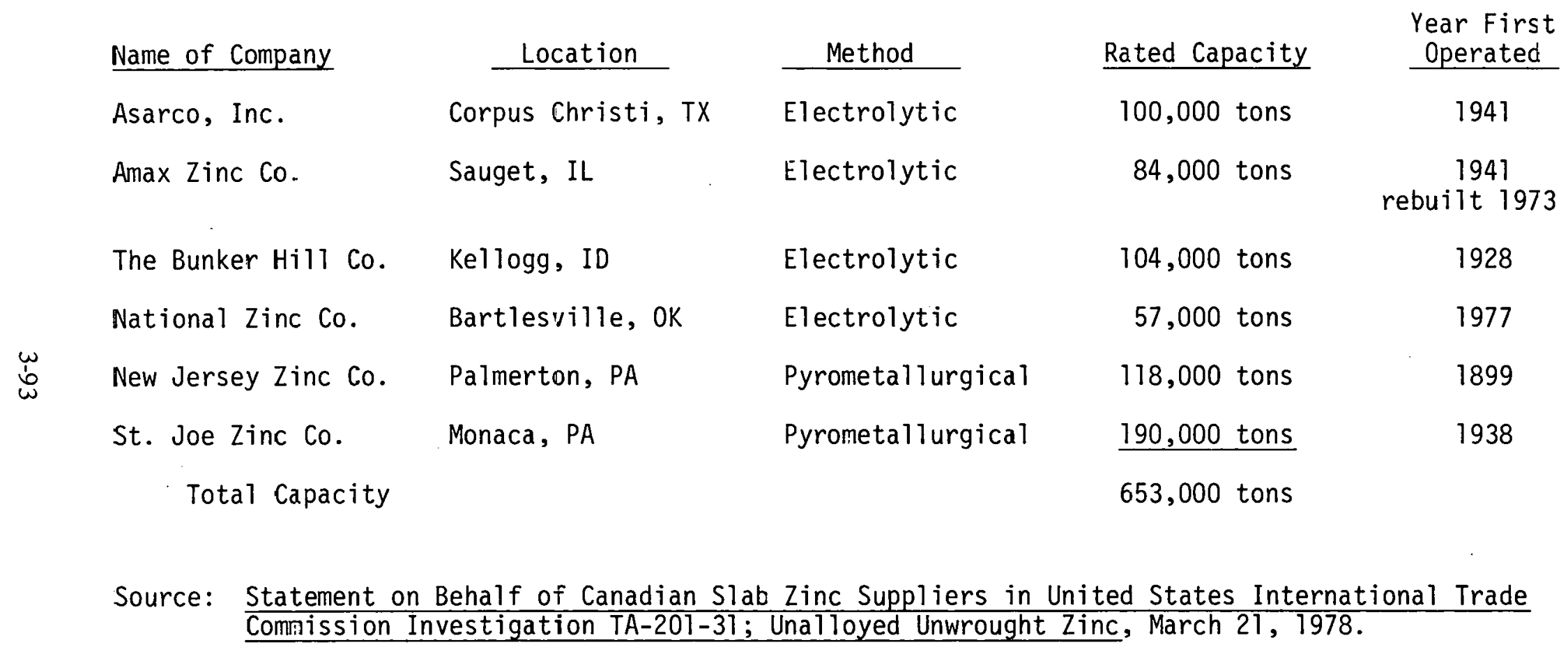


TABLE 3.5-2

SECONDARY ZINC DISTILLERS

Alger Pattern Work, Inc.

Arco Die Cast and Metal, Inc.

Asarco

Federated Metals Division:

Sand Springs Plant

Trenton Plant

Whiting Plant

Belmont Smelting and Refining Works

W. J. Bul lock, Inc.

Gulf Reduction Corporation

T. L. Diamond Company

Meadowbrook Metal \& Chemical Division

Hugn Neu-Proler

Illinois Smelting and Refining Company

New England Smelting Works Company

Pacific Smelting Company

Proler Company

Prolerizer-Schiabo-Neu Corporation

S. G. Metals Industries
Indianapolis, IN

Detroit, MI

Sand Springs, OK

Trenton. NJ Whiting, IN

Brooklyn, NY

Fairfield, AL

Houston, TX

Spelter, WV

Los Angeles, CA

Chicago, IL

West Springfield, MA

Torrance, CA

Houston, TX

Bayonee, NJ

Kansas Cit.y, KS

Source: Mineral Yearbook 1975, Volume I, Metals, Minerals and Fuels, U.S. Department of the Interior, Bureau of Mines, Washington, D.C., 1977, p. 1486. 


\subsubsection{Process Technology}

Reduction of the ores and concentrates to zinc in primary smelting and refining is accomplished by electrolytic deposition from a sulfate solution or by distillation in retorts. For either method the zinc concentrate is first roasted to eliminate most of the sulfur and produce impure zinc oxide.

At electrolytic zinc plants, roasted zinc concentrate is leached with dilute sulfuric acid to form a zinc sulfate solution. This solution is then purified and piped to electrolytic cells, where the zinc is deposited on aluminum cathodes. The electrolysis of the solution produces sulfuric acid, which is used again in leaching. Byproducts are cadmium recovered from the leach liquor and lead, gold, and silver recovered from residues. The residues are usually shipped to a lead smelter, where the lead, gold, and silver content is recovered in lead bullion.

The primary zinc industry uses two types of distillation retorts, both of which are of a vertical continuous feed construction. One type of vertical retort is heated externally by fuel while the other uses electrical resistance heating through the retort charge. Both distillation retorts use coke to reduce the zinc ore to metal. The zinc metal vaporizes and is collected as liquid zinc metal in condensers. The liquid zinc can be further purified for special applications in a distillation column or cast directly into slab zinc.

The average energy consumption in the primary zinc industry from mines to slab zinc is 65 million Btu per short ton of zinc, with the lowest energy consumption in the electrolytic reduction cells ( 60 million Btu per short ton) ${ }^{1}$ and the highest for the electric heated vertical retort (72 million Btu per short ton). ${ }^{1}$

The secondary zinc industry uses three major types of equipment: retort distillation, muffle furnace distillation, and pot melting. Both the retort distillation and muffle furnace are batch processes where the zinc scrap is heated externally by fuel, causing the zinc metal in the scrap to vaporize and be collected in a condenser. One major process difference in the secondary retorts is that there is very little reduction of zinc oxides to zinc metal. Since little energy is supplied for reducing oxides to metal, the energy per short ton of zinc is much lower in the secondary industry with distillation retorts requiring 24 million Btu per short ton of zinc and muffle furnaces about 20 million Btu per short ton. ${ }^{2}$ This includes all energy required in scrap collection, preparation, aind lrauspurtaliun, as well as the smelting itself. Pot melting of clean die-cast scrap for realloying is a very simple process that melts zinc scrap without vaporization and thus has a very low energy consumption of about 2.5 million Btu per short ton of zinc. ${ }^{2}$ Significant savings result for each short ton of zinc recovered from scrap metal zinc rather than from ore concentrates. However, some scrap - flue dusts and galvanizer ashes, which are oxidized - must be processed in primary smelters.

\subsubsection{Materials Flow}

\subsubsection{Geruerul}

The different segments of the U.S. zinc industry use differing mixes of raw materials and produce differing mixes of zinc products. 
Primary electrolytic refineries start with ore concentrates, both domestic and imported, as their primary raw material. They process very little scrap material. The extremely pure grade of slab zinc produced at electrolytic refineries is used where metal impurities could be detrimental, such as in zinc die castings. Primary distillation retorts also process ore concentrates, but supplement their feed with a significant amount of recoverable materials, especially new scrap from galvanizing operations. The basic type of slab zinc from distillation retorts, prime western grade, is used primarily in galvanizing steel products. The distillation retorts also produce zinc dust and zinc oxide for chemical use.

The secondary distillers and pigment plants use a wide variety of scrap and byproduct as raw material. They produce a small amount of slab zinc, but they are significant sources of zinc oxide and zinc powder.

\subsubsection{Classification of Recyclable Materials}

Zinc scrap is classified as prompt industrial scrap if it comes from a fabricating or semifabricating operation and old scrap if it comes from discarded products. The prompt industrial scrap and old scrap are further subdivided into the following six categories:

Prompt Industrial Scrap:

Galvanizers (primarily drosses, zinc skimmings, sal skimmings and ashes) is the largest scrap category.

New Die Cast includes defective new castings and skimmings produced from castings.

Chemical Residues and Flue Dusts is a miscellaneous category of recoverable materials which includes all zinc-bearing residues from chemical manufacture and flue dusts from all ferrous and nonferrous smelters. The flue dust should contain about $30 \%$ zine by weight.

Home includes scrap recovered and reprocessed by producers of zinc products.

\section{Old Scrap:}

Mixed Die Cast consists of such products as auto shredders' scrap, old auto parts, and old appliance parts. It forms a substantial portion of the total old zinc scrap supply.

General Zinc includes such items as old zinc and engravcrs' plates. This scrap category is a relatively minor element in the secondary zinc industry.

\subsubsection{Recycling Profile}

Both prompt industrial scrap and old zinc scrap are recovered to produce a scrics of products including slab zinc, zinc oxide, pigments, chemicals, zinc based alloys, and zinc dust. Zinc metal contained in scrap was recovered with an average yield of 90\%, as shown in Figure 3.5-1. Most of the scrap, 128,000 short tons, was prompt industrial scrap from industries that consume zinc like galvanized scrap, and ashes and die-cast scrap. About 58,000 short tons of zinc were recovered from old scrap; a major source was obsolete die-cast scrap from automobiles that have been shredded.

The five figures starting with Figure 3.5-2 outline the material flows for both the primary and secondary segments of the zinc smelting industry. 


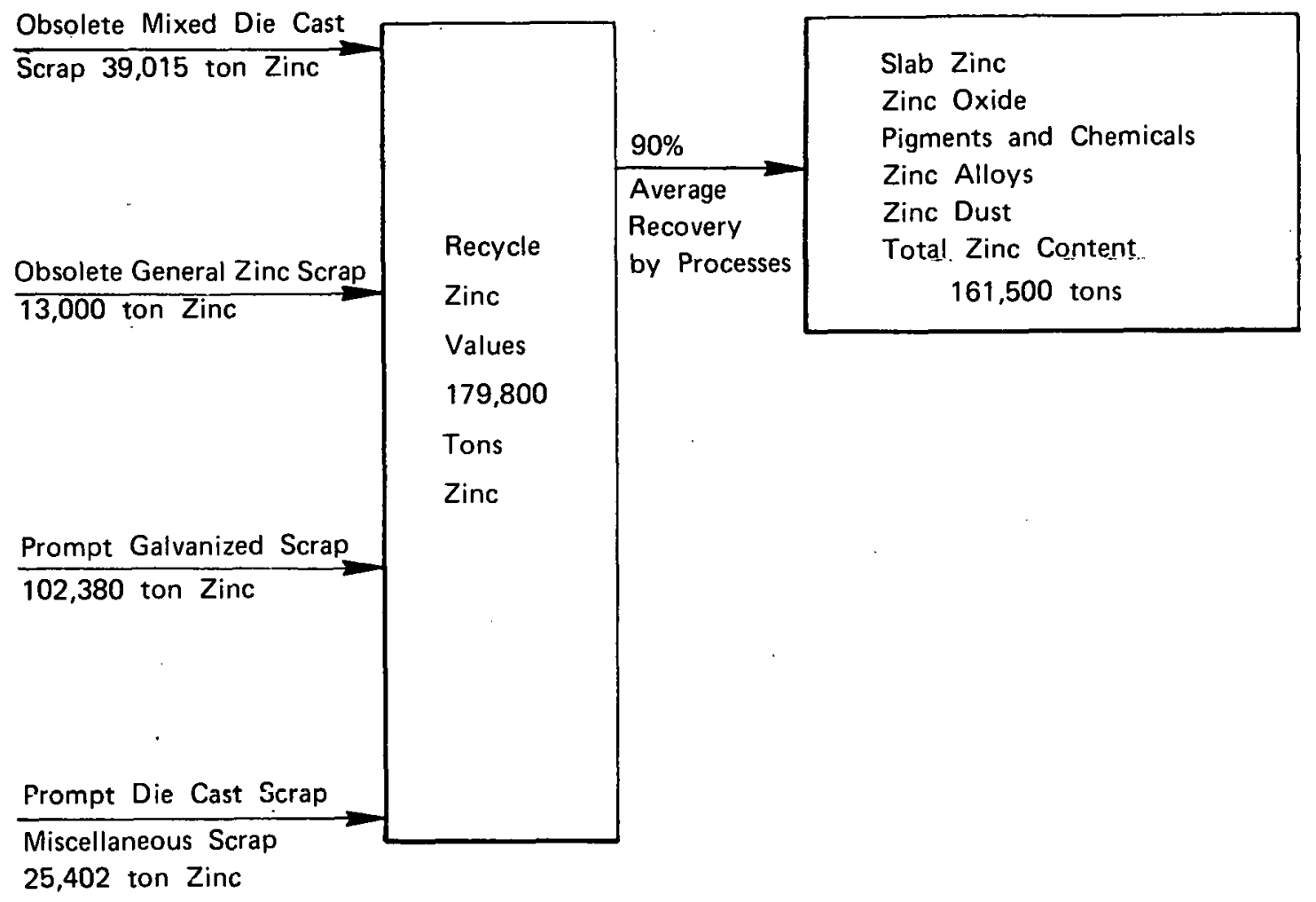

Source: $\quad$ Nonferrous Metal Data 1976, American Bureau of Metal Statistics Inc. New Yulk, N.Y. 1977, ,. 60 anil Einergy Use Falleirits for Melal Recycling U.S. Department of the Interior, Bureau of Mines, Contract Number JO-166-143, January 1978

FIGURE 3.5-1 SCRAP COLLECTION BY SOURCE-1976 


\section{Source}

(Recoverable Zinc Content)

Process Product

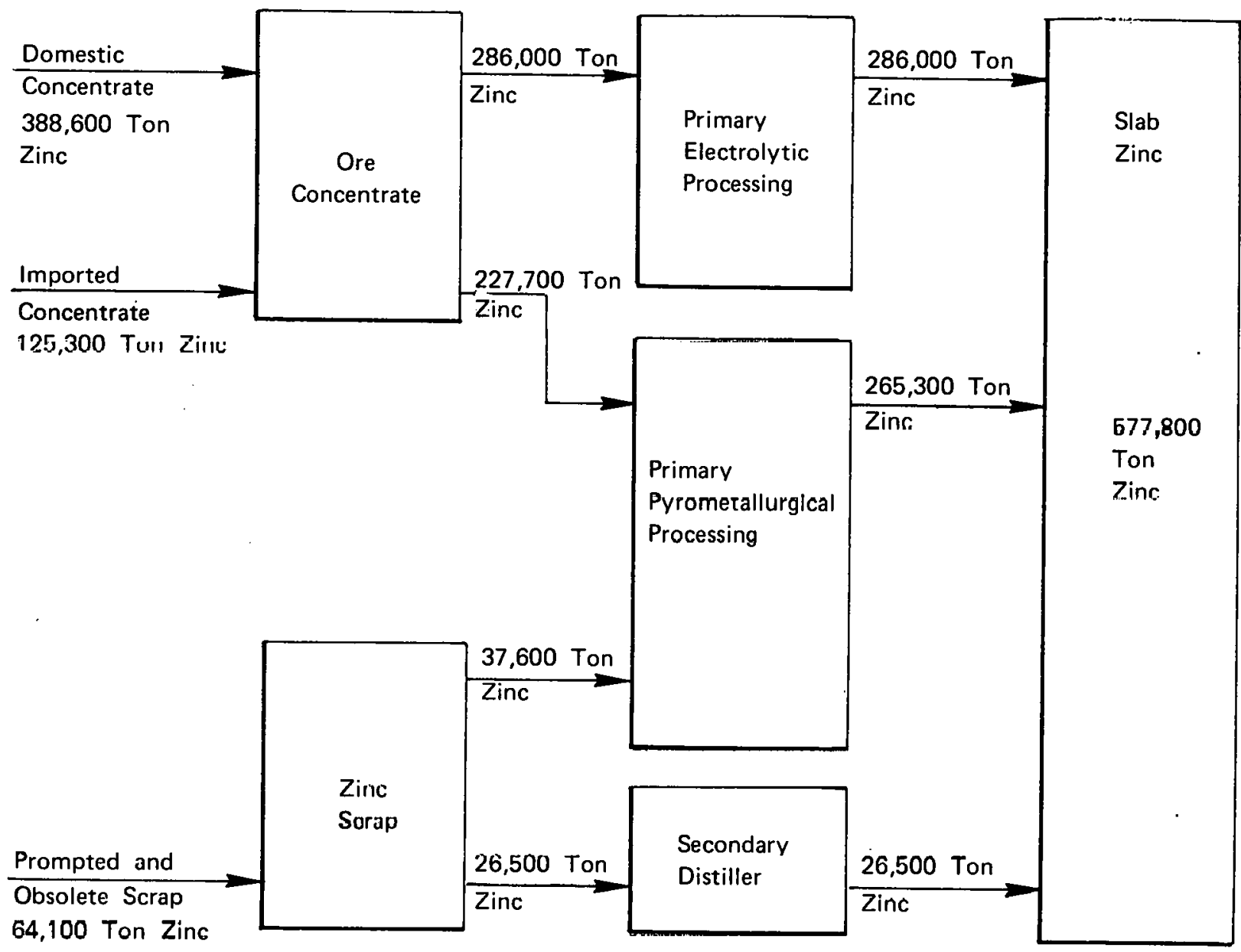

Source: Nonferrous Metal Data 1976, American Bureau of Metal Statistics, Inc. New York, N.Y. 1977 , p. 66.

FIGUTE $3.5-2 \quad$ SLAB 7INC. FI_NW DIAGRAM 1976 
In summarizirig the data in the figures, the following observations can be made:

Figure 3.5-2 shows that $10 \%$ of slab zinc comes from zinc scrap.

Figure $3.5-3$ shows that $11 \%$ of zinc oxides come from zinc scrap.

Figure 3.5-4 shows that $54 \%$ of zinc pigments and chemicals come from scrap.

Figure 3.5-5 shows that $2 \%$ of zinc alloys come from scrap.

Figure $3.5-6$ shows that $75 \%$ of zinc dust comes from zinc scrap.

The recovered materials replace both ore concentrates and slab zinc in the various product applications.

\subsubsection{Future Trends}

The United States has been an importer of either zinc ore concentrates or slab zinc since 1941. Table 3.5-3 shows U.S. mine production compared with zinc demand in the United States from 1957 to 1.977 , and estimates for $1985 .^{(3)}$ The United States will have had to import about 0.41.0 million short tons per year of zinc values during this 28 -year period. Any increase in recycling of domestic scrap and wastes may reduce the import requirements. Present trends indicate demand will increase about $2 \%$ per year from 1977 to 1985 and mine production will increase by 2$5 \%$ pcr year over the same period.

The U.S. primary smelting capacity dropped from 1.2 million short tons per year in 1968 to 0.6 million short tons per year in 1976. In 1978 a new 90,000 ton-per-year electrolytic plant came on stream. All of the obsolete horizontal retort primary plants have closed, as have most of the very old smelters. Most of the U.S. present and future in domestic zinc production will be made up by importing slab zinc. Slab zinc imports amounted to 695,000 short tons in 1976 and imported zinc concentrates contained another 125,000 short tons of zinc.

Most zinc markets will face increasing competition from aluminum and plastics. The competition from substitutes will be most severely felt in die cast materials.

\subsection{LEAD}

\subsubsection{Industry Definition}

The lead industry as defined in this study includes plants in the following SIC categories:

- SIC 3332 - Primary smelting and refining of lead - establishments primarily engaged in smelting lead from the ore and in refining lead by any process.

- SIC 3341 - Secondary smelting and refining of nonferrous metals - establishments primarily engaged in recovering lead and lead alloys from new and used scrap and dross.

- SIC 3356 - Rolling and drawing of nonferrous metals (N.E.C.) - establishments primarily engaged in producing lead and lead base alloy mill shapes.

- SIC 3369 - Nonferrous Foundries (N.E.C.) - establishments primarily engaged in producing lead die castings. 
Source

(Recoverable Zinc Content)

Process

Product

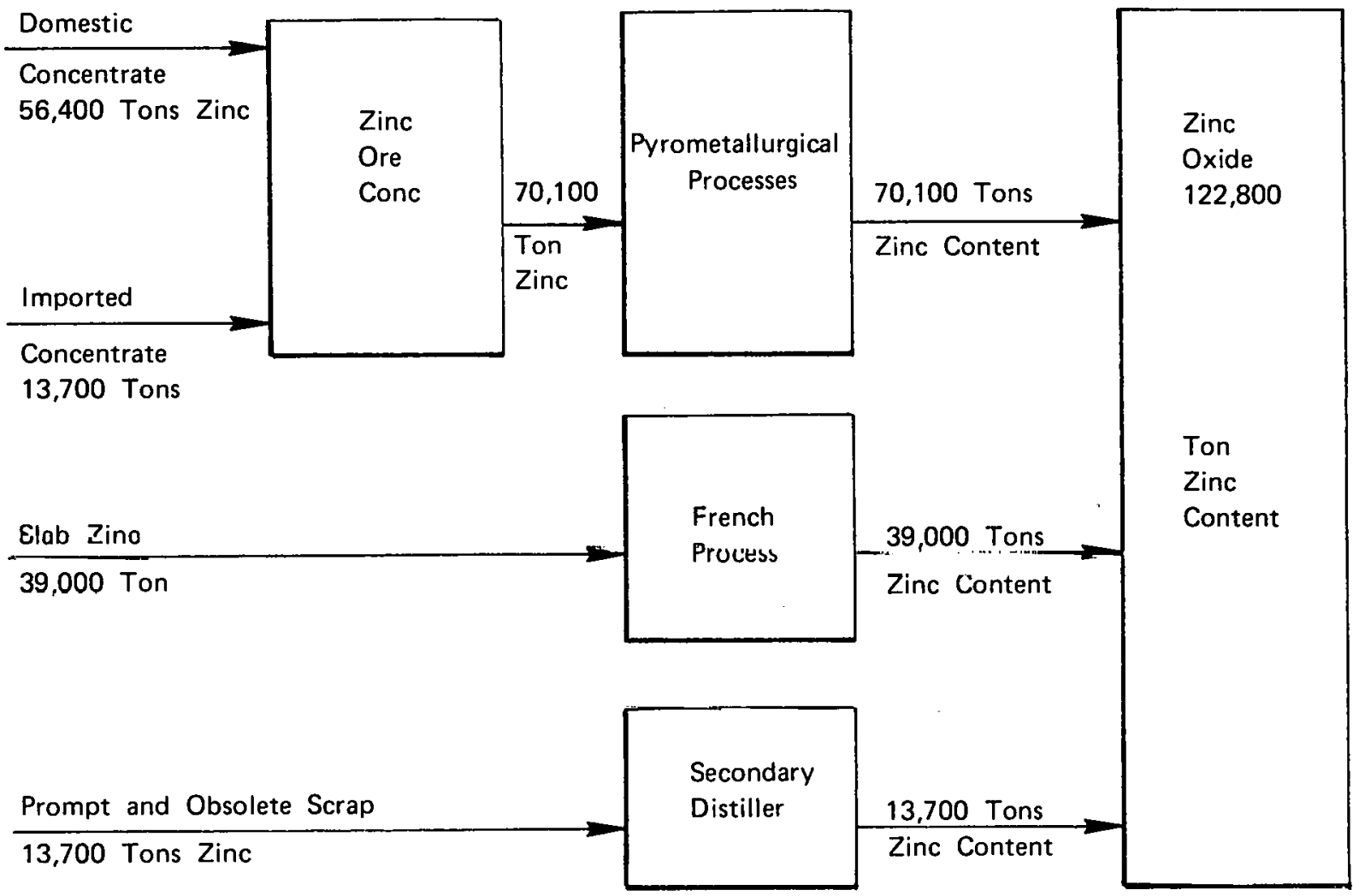

Source: Nonferrous Metal Dato 1976. American Bureau of Metal Statistics, New York, N.Y. 1977, p. 66.

FIGURE 3.5-3 ZINC OXIDE FLOW DIAGRÁAîI 


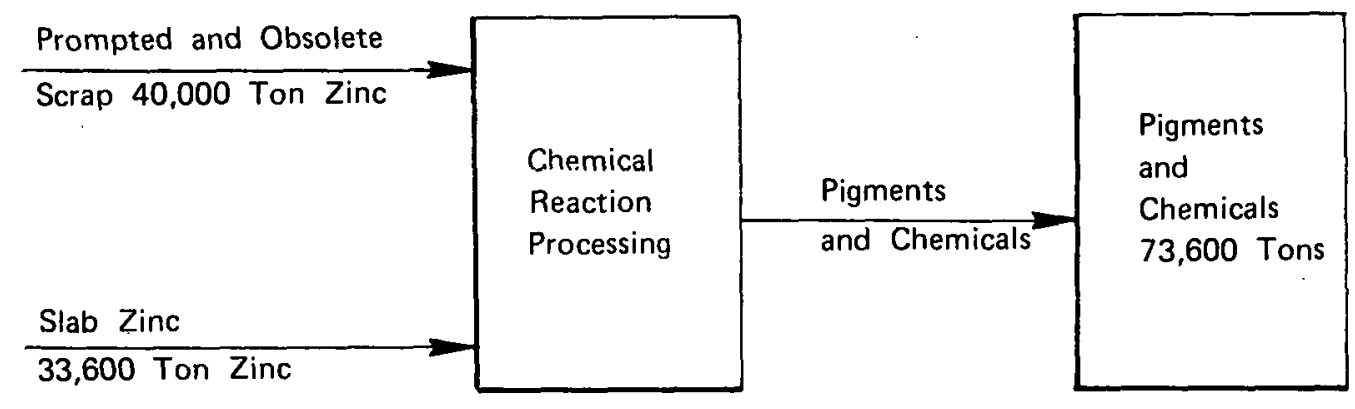

Source: $\quad$ Nonferrous Metal Data 1976, American Bureau of Metal Statistics Inc. New York, N.Y. 1977, p 66.

FIGURE $3.5-4 \quad$ ZINC CHEMICALS FLOW DIAGRAM 1976 


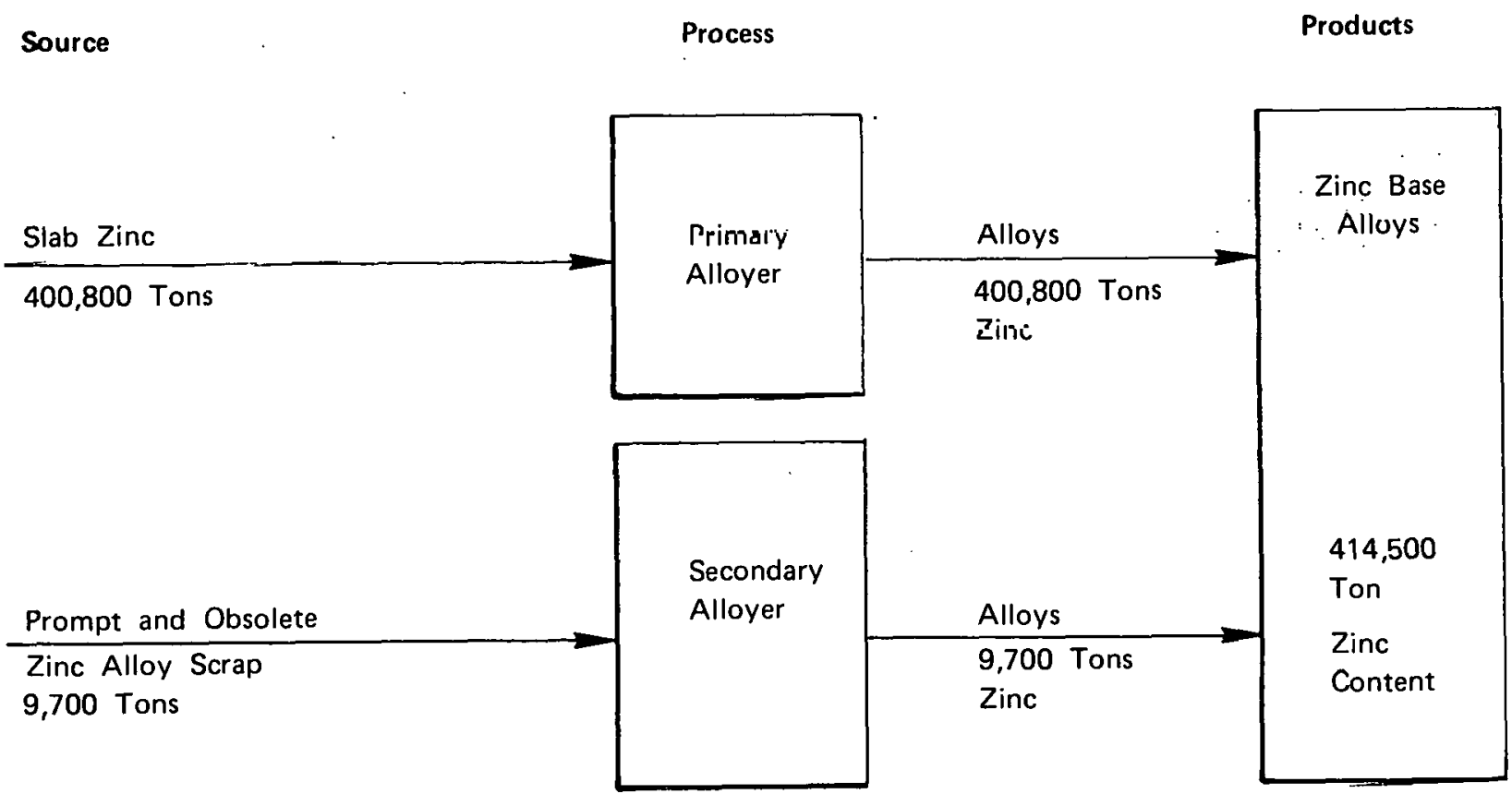

Source: Nonferrous Metal Data 1.976. American Bureail al Metal Stätiztıcs lnc. New York, N.Y. 1977, p. 66.

FIGURE 3.5-5 ZINC BASE ALLOYS FLOW DIAGRAM 


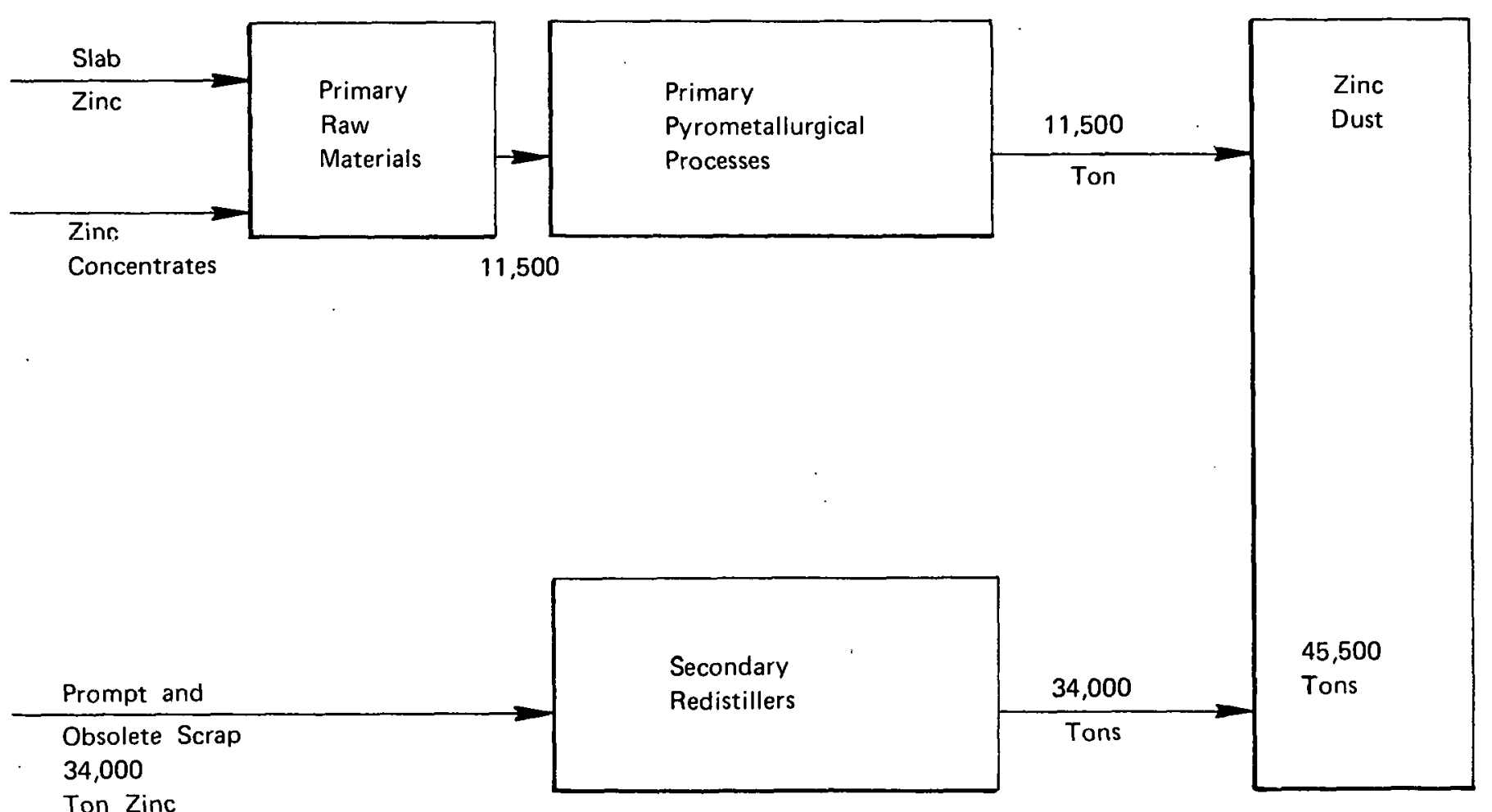

Ton Zinc

Source: Nonferrous Metal Data 1976, American Bureau of Metal Statistics.

New York, N.Y. 1977, p.66.

FIGURE 3.5-6 ZINC DUST FLOW. DIAGRAM 1976 
TABLE $3.5-3$

COMPARISON OF DOMESTIC ZINC PRODUCTION AND DEMAND

1957-1977 and 1985

(Thousands short tons, recoverable zinc)

\begin{tabular}{lrr}
\hline Year & $\begin{array}{c}\text { U.S. Primary } \\
\text { Demand }\end{array}$ & $\begin{array}{c}\text { Domestic } \\
\text { Mine Production }\end{array}$ \\
\cline { 2 - 2 } 1957 & 974 & 532 \\
1958 & 948 & 412 \\
1959 & 1,053 & 425 \\
1960 & 956 & 435 \\
1961 & 977 & 464 \\
1962 & 1,107 & 505 \\
1963 & 1,103 & 529 \\
1964 & 1,111 & 575 \\
1965 & 1,349 & 611 \\
1966 & 1,467 & 573 \\
1967 & 1,322 & 549 \\
1968 & 1,411 & 529 \\
1969 & 1,500 & 553 \\
1970 & 1,290 & 534 \\
1971 & 1,242 & 503 \\
1972 & 1,438 & 478 \\
1973 & 1,564 & 479 \\
1974 & 1,452 & 300 \\
1975 & 1,072 & 469 \\
1976 & 1,276 & 485 \\
1977 & 1,228 & 458 \\
1985 & 1,500 & $529-600$ \\
& &
\end{tabular}

Source: V. Anthony Cammarota, Zinc Mineral Commodity Profiles, U.S. Department of the Interior, Bureau of Mines, MCP-12, May 1978, p. 24. 
Of the plants in the above SIC categories, the primary (3332) and secondary (3341) lead smelters account for most of the value of production and energy consumption. Therefore, only these two SIC categories are considered in this analysis.

\subsubsection{Industry Structure}

The United States is the largest producer and consumer of refined lead in the world. U.S. mines produce more lead than any other country in the world. U.S. primary production is greater than in any other country, and U.S. secondary production is larger than total production of any other country. In addition, significant quantities of ores, concentrates, base bullion, and pig lead are imported into the United States.

An overview of the domestic lead industry is presented in Figure 3.6-1. Lead is principally consumed in batteries, gasoline, cables, pigments, and ammunition, with batteries accounting for over $50 \%$ of total consumption (see Table 3.6-1). The demand for lead is a derived demand; it is demanded for use in the production of other commodities. Since lead usually represents only a small portion of the total cost of the commodity, lead demand is not very sensitive to price in the short run. Secondary lead competes with primary metal in all but a few uses.

The four major types of lead products are: soft lead (pig), antimonial lead, miscellaneous alloys, and lead oxides, pigments and chemicals. Most of the standard grades of soft lead (pig) can be or are produced from scrap. Antimonial lead is a generic name for a number of lead alloys containing antimony and used mainly in battery manufacturing. It is usually produced from battery scrap by secondary smelters. Miscellaneous alloys include babbit, solders, and type metals, which are normally produced to user or standardized specifications or under brand names, usually from both secondary and primary materials. Lead oxides, which are used in battery manufacturing; lead pigments; and lead chemicals, which are used as gasoline antiknock additives, are usually pruduced from primary soft lead.

\subsubsection{Primary Producers}

Lead is produced by the primary industry from lead-bearing ore, most of which is mined in the United States although some is imported from Australia, Canada, and Peru. About $80 \%$ of the domestically mined lead is produced in Missouri; most of the remainder comes from Idaho, Colorado, and IItah. The lead smelters tend to be located near the mines and can be differentiated as either Missouri, or non-Missouri smelters. Missouri lead ores contain zinc as a coproduct, byproduct copper, and small amounts of silver and bismuth but few other impurities. Smelters treating Missouri ores have been constructed to handle only low levels of these impurities, and consequently cannot utilize Western ores with their much higher impurity levels. NonMissouri smelters have much more extensive refining facilities and handle the higher byproduct levels found in the Western ores.

Four companies operating six smelters and five refineries produce primary lead metal in the United States (see Table 3.6-2). They are large, integrated, multi-plant companies producing a variety of non-ferrous metals and other products. They are generally not integrated into fabrication, although there are some specific exceptions.

Bunker Hill operates a 140,000 short ton per year (stpy) lead smelter and a 130,000 stpy refinery in Kellngg, Idaho. Bunker Hill is integrated backward into mining, by itself and in joint 


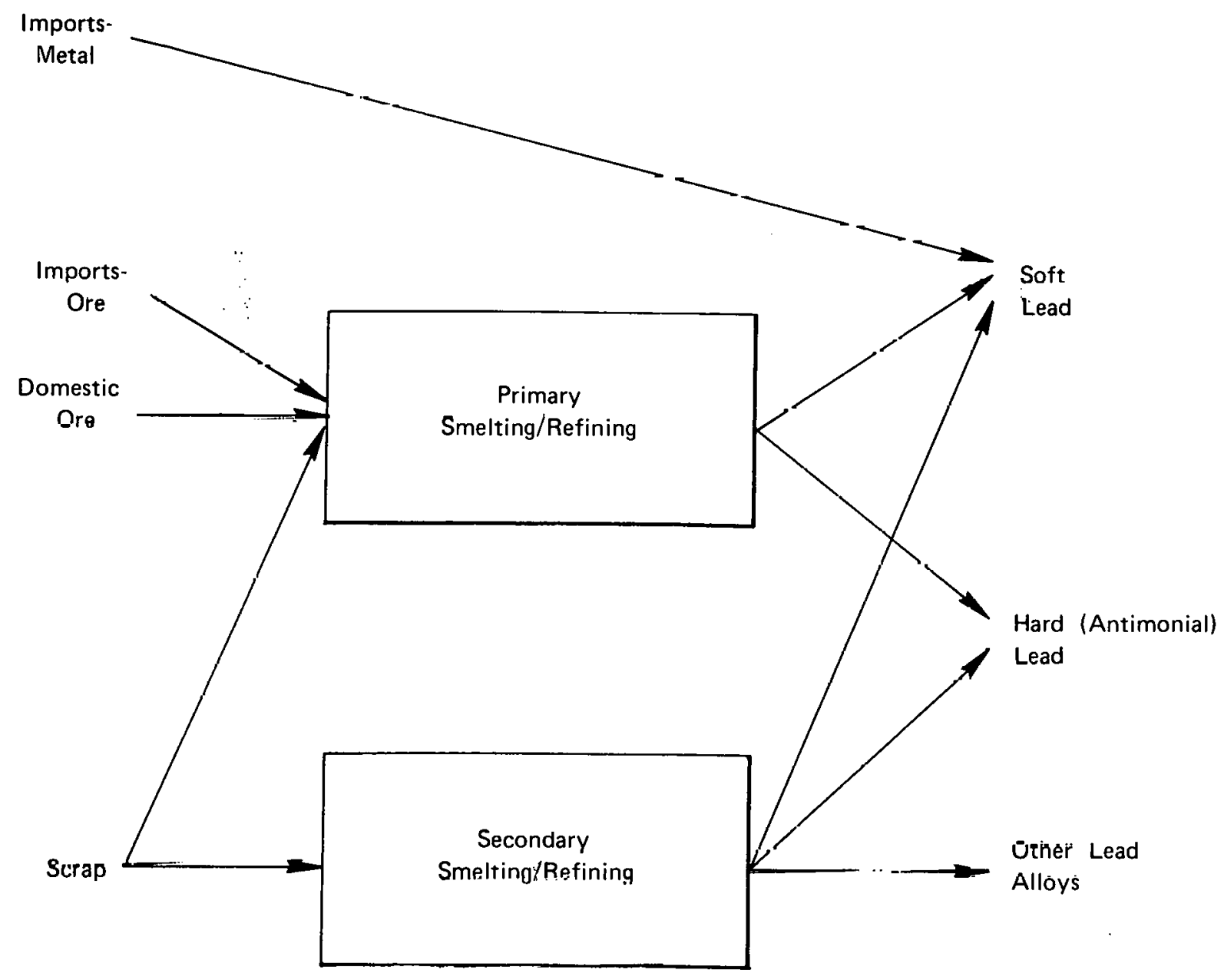

FIGURE 3.6.1 INDUSTRY STRUCTURE - LEAD 
TABLE 3.6-1

LEAD CONSUMPTION BY END-USE MARKET - 1976

\author{
SHORT TONS
}

Gasoline Additives

240,000

Batteries

822,000

Pigments

106,000

Ammunition

73,000

other

249,000

Tota 1

$1,490,000$

Source: American Bureau of Metal Statistics, 1977 
TABLE 3.6-2

\section{LEAD SMELTERS/REFINERS}

Company

Asarco, Inc.

Bunker $\mathrm{Hill}$

Bunker Hị 1

Asarco, Inc.

Asarco, Inc.

Asarco, Inc.

Amax-Homestake

St. Joe Lead Co.
Location

Omaha, Nebraska

Kellogg, Idaho

Kellogg, Idaho

East Helena, Montana

E1 Paso, Texas

Glover, Missouri

Boss, Missouri

Herculaneum, Missouri
Facility

Refinery

Refinery

Smelter

Simeller

Smel ter

Smelter/Refinery (c) $\quad 110,000$ ST (a)

Smelter/Refinery (c) 140,000 ST (a)

Smeiter/Refinery (c) 225,000 ST (a)

(a) refined lead

(i) charge capacity

(c) limited to the refining of lissouri concentrates

Source: American Bureau of Metal Statistics, 1976 
ventures. In 1976, about $30 \%$ of the concentrate used at Bunker Hill was from its own mines. The rest was purchased from other mines in the area and smelted on a custom basis. Bunker Hill is not forward integrated into fabrication.

Asarco, Inc. operates lead smelters at El Paso, Texas, East Helena, Montana, and Glover, Missouri; they have a lead refinery in Omaha, Nebraska, which refines the lead bullion from El Paso and East Helena: Asarco is extensively integrated horizontally with various plants and divisions smelting and refining a large number of metals including lead, zinc, copper, a variety of precious metals, and high-purity metals. Asarco is integrated back to the mine level but acquires most of its concentrate on a custom or toll basis. In 1976, only $6 \%$ of the lead produced by Asarco was from its own mines. Asarco also owns Federated Metals Corporation which produces lead and other metals and alloys from secondary materials and also operates some fabrication facilities.

St. Joe Minerals operates a lead smelter in Herculaneum, Missouri, which is almost totally self-sufficient on company production of lead concentrate. St. Joe occasionally does some custom smelting, but is not forward-integrated into fabricaliun.

The smelter at Buick, Missouri, is a joint venture of Amax, Inc. and Homestake Mining Company. Half of the capacity at Buick is committed on a tolling contract to an outside source of concentrates. The remainder is used to treat concentrate from the Amax-Homestake mine, not all of which can be treated at Buick because of capacity limitations.

\subsubsection{Secondary Producers}

The secondary lead industry produces soft (refined) lead and lead alloys (principally antimonial lead) from lead scrap. Lead scrap can be either new (generated in the process of refining, casting, or fabricating leaded materials), or old (from obsolete materials that have reached the end of their useful life).

Secondary smelters receive about $75 \%$ of their old scrap from batteries; in fact much of their production is destined for battery plates and oxides. In the secondary sector, some vertical integration exists among large battery producers who smelt their own lead. Such integration provides a more secure supply of scrap from recycling old batteries. Nevertheless, the trend in vertical integration is not yet far enough advanced to affect entry conditions significantly.

Because scrap resources are widely distributed in urban areas, require no special technological expertise to collect, are more homogeneous than many ores, and require less complex smelting and refining plants than primary sources, entry into the secondary industry is relatively easy.

There are about 85 companies operating more than 100 plants to produce lead from scrap. The secondary smelting industry is dominated by large vertically or horizontally integrated producers interspersed with a number of regional independent producers.

Most of the independent producers are less efficient than the large integrated producers. The principal integrated secondary lead smelters and refineries are listed in Table 3.6-3. Major independent smelters and refineries (not a subsidiary of a vertically or horizontally integrated company) are shown in Table 3.6-4. 
TABLE 3.6-3

INTEGRATED SECONDARY LEAD SMELTERS AND REFINERS*

\author{
Asarco (Federal Metals Division) \\ Contract Manufacturing (Chloride Metals) \\ General Rat.tery \\ Gould, Inc. \\ NL Industries \\ RSR \\ Western Electric (Nassau Recycle)
}

* Note: This is not a complete listing.

Source: Preliminary Technological Feasibility, Cost of Compliance and Economic Impact Analys is of the Proposed OSHA Standard for Lead. John Short and Associates, January 4, 1977. 
TABLE $3.6-4$

INDEPENDENT SECONDARY LEAD SMELTERS AND REFINERS*

ALCO Mining

Allied Smelting

East Penn Manufacturing Co.

Florida Smelting

Gopher Sinelting \& Refining

Gulf Coast Lead

Hyman Viener \& Sons

Inland Metals

Lead Products Co.

Roth Brothers Metal Co.

Schuykill Metals

Seitzinger's Inc.

Willard Smelting Co.

* Note: This is not a complete listing.

Source: American Bureau of Metal Statistics, 1977 
Two of the integrated companies (NL Industries, Inc. and RSR Corporation) account for about $60 \%$ of secondary lead capacity. Thirteen other companies operating about 25 plants produce most of the remainder.

RSR operates five secondary smelters located in Texas, Indiana, California, New York, and Washington State. Some of the lead is converted to oxides or fabricated into products (two fabrication plants and two oxide plants). Both soft and alloyed lead are produced with the split approximately $70-30 \%$.

NL is a large diversified company, producing lead, oxides, and fabricated products in mure than 20 plants scattered throughout the United States. Most NL lead is sold to battery manufacturers.

The large integrated national producers are surrounded by independents serving regional markets. Most of the remainder of the plants are small and scattered, although a few are the result of vertical integration of the battery industry. These smaller regiunal firms liave an average of about 60 employees and produce an average of approximately 8000 short tons of lead per plant per year.

The secondary industry actively competes with the primary lead companies both nationally and internationally. Secondary producers can and do sell abroad, and they can compete favorably with primary producers.

The small secondary firms have smaller capacity, which limits the number of large customers they can serve, leaving them to serve primarily the smaller, more competitive regional market. When the domestic price leaders increase prices, the smaller secondaries will usually follow. On the other hand, when attempts are made to support prices by limiting the supply of lead, the smaller secondaries have shown little hesitation in taking full advantage of the support price without limiting their output.

\subsubsection{Proocss i iecnnology}

\subsubsection{Primary Smelting and Refining}

Although all of the lead smelters in the United States are essentially based on the same process, the Western smelters employ more complicated flowsheets because of the more complcx nature of the Western concentrates and other imported material, and the smelters' relationship with copper and zinc plants. Figure 3.6-2 depicts a generalized flowsheet of a primary lead smelter.

The primary raw material is lead sulfide concentrate. This is mixed with direct smelting ore rich in silica, zinc plant residues, siliceous and limestone flux, and small quantities of scrap iron if necessary. The charge is prepared by mixing, sizing and crushing. Recycled sinter fines are also blended in with the charge to form the feed to the sintering operation.

The purpose of sintering is the elimination of the sulfur in the charge and the production of a dustfree lumpy charge suitable for treating in a blast furnace. The charge to the blast furnace consists of coarse sinter with about $10-12 \%$ lump coke. Low pressure air is blown into the blast 


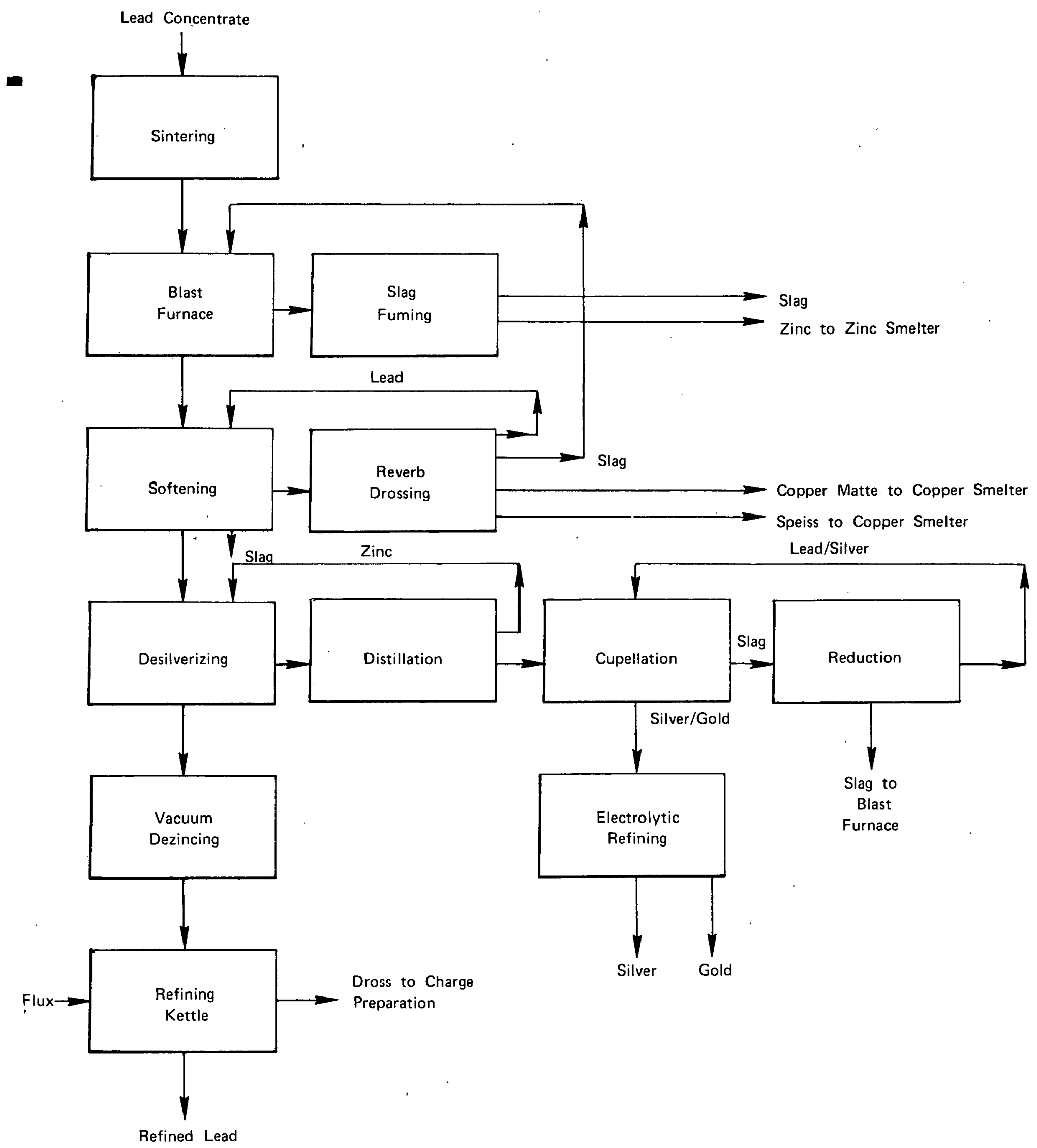

FIGURE 3.6.2 PRIMARY PRODUCTION OF LEAD 
furnace. Lead oxide in the sinter is reduced to metallic lead by carbon monoxide formed by the partial combustion of the coke. The heat for melting the charge is derived from the combustion of coke or carbon monoxide to carbon dioxide. Under the mildly reducing conditions in the furnace, zinc oxide is not reduced to the metal and accumulates in the slag.

The liquids from the blast furnace are tapped continuously to an external settler. In the settler, the liquid separates into two layers, molten lead and a molten slag. If the charge contains a sufficient number of other impurities, there will be intermediate layers of "matte" and "speiss." The matte layer is predominantly copper, iron, nickel, and cobalt sulfides while the speiss layer contains a mixture of complex copper arsenides and antimonides. Cadmium in the charge is volatilized. When the slags contain over $8-10 \%$ zinc, they are retreated in slag fuming furnaces to recover the zinc and any remaining lead. Western smelters treat high zinc materials and require slag fuming facilities while the Missouri smelters do not.

Lead bullion from smelters operating on Missouri ore is pure enough for most commercial uses without complex refining. Lead bullion produced from Western and most foreign ore contains enough guld and silver to make recovery prnfitable. It also containo various buse metal impurities that must be removed before the lead is marketable for end use. Processing for impurity removal consists of softening, desilverizing, dezincing, and final refining of the lead bullion.

Softening consists of the removal of copper, tin, antimony, and arsenic in a drossing or refining kettle. Copper is removed by heating the bullion to just above the melting point and skimming copper dross from the surface. Agitation and addition of elemental sulfur causes any remaining copper to rise to the surface as a black copper sulfide dross which is skimmed off. The copper drosses undergo further treatment to maximize lead recovery. After copper drossing, the lemperature of the bullion is raised and the bath is agitated to induce surface oxidation. Tin, arsenic, and antimony are oxidized and the oxides rise to the surface with some lead oxide and are skimmed off na slag.

The suftented bulliun is usually desilverized by the Parkes process (stirring metallic zinc into the bullion). Gold and silver combine with the zinc, and the resultant alloys, on cooling, rise to the surface and are skimmed off. The zinc remaining in the lead after desilverizing is removed by vacuum distillation: Remaining traces of zinc, arsenic, bismuth and antimony are removed by the Harris process and the lead is cast as bullion.

The recovery of byproducts is subject to many variations in practice but they are beyond the scope of this discussion.

\subsubsection{Secondary Lead Proce.ssing}

The secondary lead industry processes lead scrap into three grades of lead ingot; refined lead (soft lead), antimonial lead (hard lead), and remelt lead and various types of specification alloy. Refined lead is produced from scrap from which elements like antimony, copper, tin, and arsenic have been removed to a level consistent with primary refined lead. Antimonial lead is produced from battery plate scrap and contains $2-7 \%$ antimony and small controlled quantities of arsenic, copper, and tin. Remelt lead is melted-down lead scrap that is pure enough or meets the necessary alloy specification so as not to require processing. 
Lead processing in the secondary industry consists of scrap preparation, melting, and refining, as shown in Figure 3.6-3.

\subsection{Scrap Preparation}

Whole battery scrap is customarily decased by sawing or guillotining to produce battery plate and separator scrap and to remove the connectors and posts. Plates and separators go into storage, and the acid drains off into a sump where it is neutralized with lime or ammonia. The battery top, containing the connectors and posts, is fed to a crusher and then to an air separator wiere the casing material is removed. The scrap prepared from this operation is called plate and separator scrap.

Some of the more recent concepts in battery scrap preparation consist of breaking the whole battery and separating the various components (lead, lead oxide, casing material) by heavy media separation and hydrometallurgical techniques. A new scheme, outlined by Paul Bergsoe and Son A/S of Denmark consists of acid removal by cracking the whole battery before charging it to the smelting furnace.

Prompt industrial scrap such as drosses, skimmings, etc., needs no preparation before processing in the furnaces. Most of the general lead scrap like cable sheating also requires little preparation.

\subsection{Scrap Smelting/Refining}

Three major smelting schemes are used to treat lead scrap: blast furnace, reverb/blast furnace combination, and pot melting.

The blast furnace is the workhorse of the secondary lead industry. It is similar in construction to the cupola used in the iron foundry industry, with cross sectional areas ranging from 5 to 16 square feet at the luyeres. The smelting zone is water jacketed: about half the furnaces also have jacketing above the smelting zone.

The charge normally consists of lead-bearing materials, such as battery plates and separators, refining drosses, slags, and battery manufacturers' scrap, as well as coke, limestone, sand, and scrap iron. Slag and matte are tapped from the furnace at regular intervals, while molten lead is removed continuously. The furnace metal is either cast into 1- to 2-ton blocks that are transported to the refinery, or are directly tapped into receiving kettles. Metal tapped into kettles is refined using various fluxes and alloyed to produce the desired specifications. Overall recovery of the blast furnace process scheme is over $95 \%$, with the difference accounted for by lead in the slag, matte, and dust.

The reverb/blast furnace scheme involves a reverberatory furnace to process most of the incoming lead scrap, and a blast furnace to recover lead and antimony values from the reverb slag. The reverb furnace is a refractory-lined, shallow-hearth, rectangular structure, fired from one end with nalural gas or oil. The dust in off-gases is collected in baghouses and recycled. The reverb furnace produces a low antimony lead (less than $1 \%$ antimony) and a high antimony slag (4-12\% antimony; $65-90 \%$ lead). The lead is transported to kettle refining for fluxing and alloying to meet final specifications. The reverb slag is cast, cooled, and charged to the blast furnace along with coke, limestone, scrap iron, sand, rerun slag, and some lead-bearing materials. The lead produced in the blast furnace contains from $2-7 \%$ antimony. 


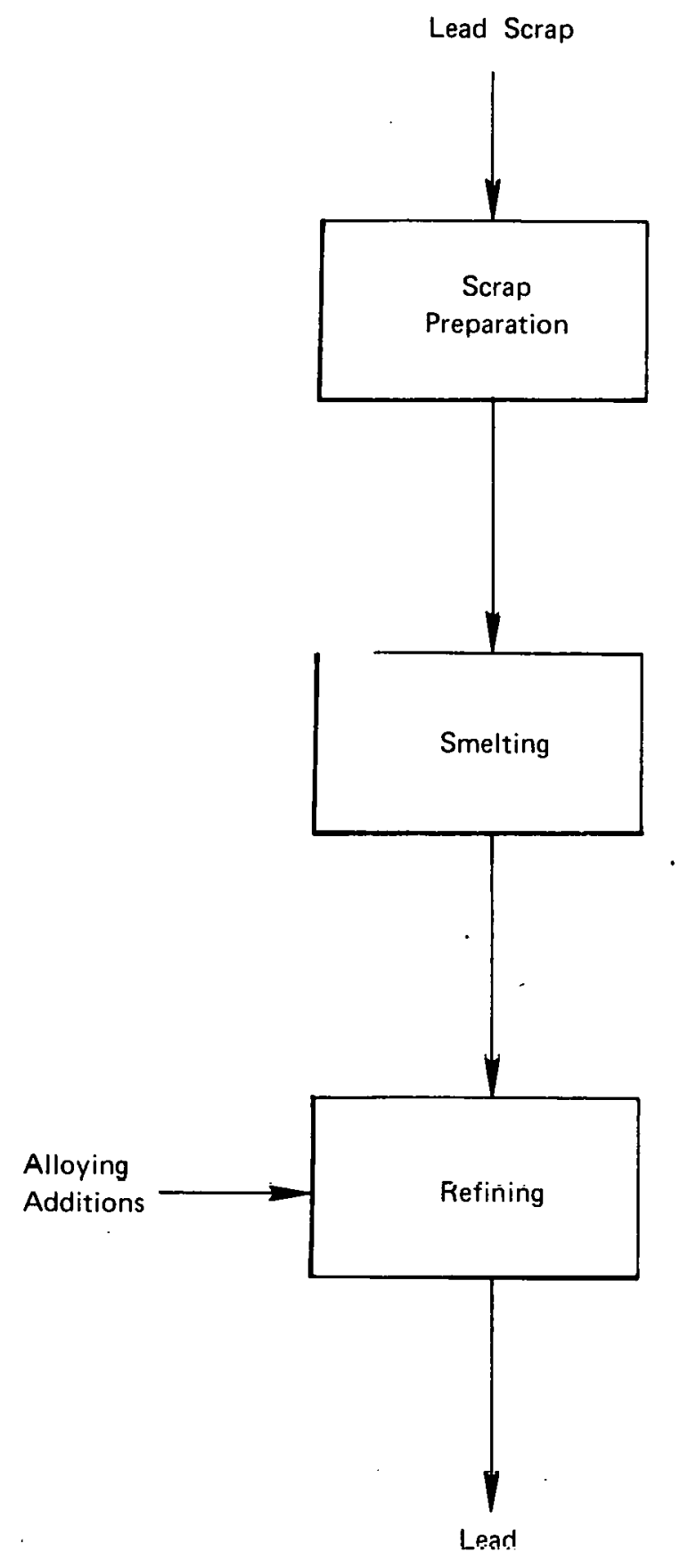

FIGURE 3.6.3 SECONDARY PRÓDUCCTION OF LEAD 
The lead from the reverb and blast furnaces is refined in steel kettles to produce "soft" (low antimony) and "hard" (high antimony) leads. Various types of fluxes, such as sodium hydroxide, sulfur, and sodium nitrate, with alloying elements, such as copper, tin, antimony, and arsenic, are added to the kellle charge to refine the lead to meet customer specifications. Overall recovery of the reverb/blast furnace scheme is over $95 \%$. The lead metal loss occurs as lead in blast furnace slag, matte, and dusts.

A very small sector of the secondary lead industry relies solely on the reverb furnace for processing lead scrap. This method is actually the front-end of a reverb/blast furnace scheme. The slag produced in the reverb furnace contains about $65-80 \%$ lead and therefore has to be treated by a blast furnace at another smelter to recover the lead.

Pot melting involves the melting of general lead scrap in an indirectly-fired steel kettle. This process is used whenever the quality of lead is unimportant (96-99\% lead), for example, for boat keels and weights. Lead recovery in this process is over $95 \%$. Pot melting operations handle very small quantities of lead compared to other smelting schemes described above.

The recent introduction of maintenance-free batteries has brought into the market a certain amount of lead scrap containing calcium and tin. The treatment of this scrap is similar to that employed for regular battery scrap, but it requires care in the refining and alloying operations.

Recently, rotary furnaces have been introduced for processing lead RM. However, their use is not widespread at present.

\subsubsection{Materials Flow}

\subsubsection{General}

The flow of material in the U.S. lead industry is depicted in Figure 3.6-4. Primary smelters use both domestic and imported concentrates as raw material. Some scrap is also consumed by primaries but only in very small amounts. Primaries produce soft (refined) lead, the bulk of which is used in batteries or gasoline (as TEL). The primaries also produce some antimonial lead but only very small amounts.

The secondary smelters and refiners use various types of scrap and hyprnducts as raw material. By far the largest single source is battery scrap. The second source of scrap is drosses and residues from manufacturing operations. Secondaries are capable of producing soft (refined) lead, antimonial lead, or other alloys, but traditionally have produced mostly hard (antimonial) lead for use in batteries.

\subsubsection{Classification of Recyclable Material}

Until recently the supply of and demand for lead scrap has been highly oriented toward specific end use segments of the overall lead industry. However, the introduction of maintenance free batteries is changing this.

Battery manufacture is the largest consumer of lead, and old batteries are the source of over half the total secondary lead processed. Antimonial lead, produced almost entirely by secondary smelters, is used for battery grids, posts, and connectors; most of the lead oxide used in batteries is prepared from primary lead. 


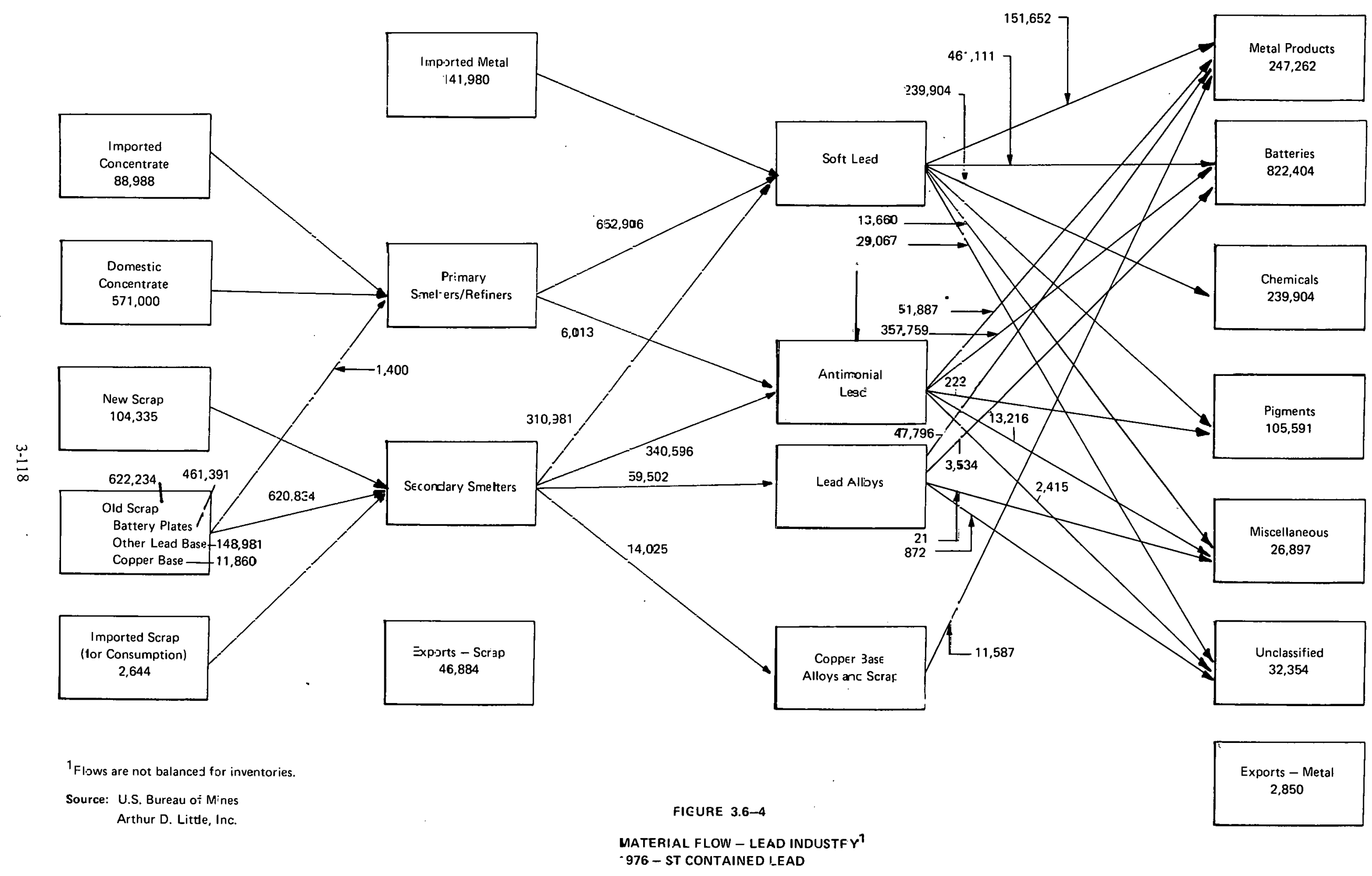


Over the long term, an average of $75 \%$ of the lead consumed in batteries is recovered as scrap about three years later. The actual consumption of battery scrap is influenced by the price of lead, however.

The major sources of old lead scrap other than batteries consists of construction scrap, type metal, cable covering, solder, and bearing and casting metals. Construction scrap includes caulking lead, pipe, and sheet lead from industrial and residential construction. Recovery is about $45 \%$ of the lead used in these products 20 years earlier. Type metals are returned as lead scrap in approximately the same quantity as shipments of new type metals with essentially $100 \%$ recovery. Lead is recovered from solder at a rate of about $17 \%$ of the lead consumed for production of solder 10 years earlier. The uses for solder are automotive, cans, electrical, electronic, and miscellaneous uses. Use in the automotive industry is principally for body solder ( 5 pounds per car) and radiators (about 3 pounds). Cable lead is returned at a rate equivalent to $25 \%$ of the cable lead used 20 years earlier. Scrap from other metal products currently supplies the equivalent of $50 \%$ of the lead that was consumed to produce bearing and casting materials 10 years earlier. Most of the lead in collapsible tubes is not recovered in the normal scrap channels. Lead in brass and bronze is not recovered as lead scrap and does not return to the secondary lead industry.

New lead scrap consists of drosses and residues, principally generated in the manufacture of various metallic lead products. Historically, recovery of lead from drosses and residues has been equivalent to about $10 \%$ of the lead consumed for metal products (battery plates, ammunition, solder, cable coverings, type metal, construction and other applications).

\subsubsection{Recycling Profile}

\subsection{Primary Industry}

In the primary lead industry two lead-containing wastes are produced and are recycled or disposed of in varying degrees: blast furnace slag, and gas cleaning wastes.

Molten slag from the blast furnace is recycled to sinter (70\%); about $30 \%$ is passed through a slag fuming furnace to remove zinc and some residual lead, then granulated by water quenching before going to the slag dump. Some smelters do not fume slag; untreated granulated slag then goes directly to the dump.

Although gas cleaning practice varies widely from plant to plant, the bulk of the dry dusts and wet slurries resulting from primary gas cleaning operations are recycled. Slurry is settled in a lagoon, which is dredged periodically. This sludge is produced at a rate of $19 \mathrm{Kg} / \mathrm{MT}$ of lead product.' At some plants this material is recycled to sinter; at others the material is not recycled but is disposed of on land as a solid waste.

A portion of the dusts collected from sintering, blast furnacing, and other operations in baghouses and other dry dust collectors is not slurried but is recycled in dry condition to the sinter machine. It has been estimated that 20,900 short tons per year are handled in this manner from the typical plant. ${ }^{1}$ Recycle is immediate and no solid waste disposal is necessary. Approximately $10 \%$ of dusts are land stored before recycle. ${ }^{1}$

\subsection{Secondary Industry}

In the secondary lead industry, slag and dusts are generated in both reverberatory furnaces and blast furnaces. In making soft lead, byproduct slag from the reverb is sent to a blast or cupola 
furnace as input for antimonial lead (i.e., hard lead) production. The emissions from the reverberatory furnace are collected in a baghouse and immediately recycled.

In the blast furnace, smelting of the reverberatory slag, along with other scrap, generates blast furnace slag having approximately the following composition: $\mathrm{FeO}, 35 \%$; $\mathrm{CaO}, 15 \%$; $\mathrm{SiO}_{2}$, $30 \%$; and $\mathrm{Pb},<1 \%$. Trace metals include zinc, copper and antimony.

With direct blast furnace smelting of scrap battery waste to produce antimonial lead, sulfur in the scrap is scavenged by iron resulting in the formation of a matte and slag together with the molten metal. About $25 \%$ of the slag is recycled as flux for subsequent smelting, the remainder is discarded. Typical chemical composition of the slag is similar to that given above. Typical chemical composition of the matte is: $\mathrm{Fe}, 61 \%$; $\mathrm{Pb}, 4.5 \%$; and $\mathrm{S}, 15 \%{ }^{1}$

\subsubsection{Future Trends}

\subsubsection{Technology}

Technological changes in the metals industry take a long time and a large investment in building new facilities. Accordingly, we expect few major changes in the technology of the lead industry between now and 1987.

There is a technological shift occurring in the battery industry, however, that may have serious repercussions for lead producers. The introduction of maintenance-free batteries has decreased the demand for antimonial lead and increased the demand for pure lead.

Antimonial lead has traditionally been produced by the secondaries from scrap while the bulk of the pure lead has been produced by primaries. Secondaries can also produce pure lead but for technical and economic reasons they prefer antimonial. The decrease in antimonial demand is increasing competition in the secondary industry, and causing secondaries to switch their product. mix to a greater proportion of pure lead, which puts them in competition with the primary producers.

This change in market structure may, in turn, affect the mix of primaries and secondaries in the industry. Additionally the emphasis on pure lead may lead to the development of new technology to produce pure lead from scrap more efficiently. (The current reverb/blast furnace combination is geared toward production of antimonial lead.) Although the primary/secondary mix will probably be altered by 1985 , we do not anticipate significant new technology by then.

\subsubsection{Demand}

'I'he consumpliun pallern for lead in 1976 is given in 'T'able 3.6-1. Domestic demand can probably be met by domestic sources in the foreseeable future. The U.S. Bureau of Mines projects an overall growth rate of $1.8 \%$ annually through the year 2000 .

An estimated 1987 breakdown is given in Table 3.6-5. A decreasc in consumption of lead in TEL is expected as EPA regulations force this phaseout although the changing energy situation and the lead specifications for gasoline could affect the decrease in the short term. Use of lead in paint decreased as a result of increased awareness of the toxic qualities attributed to lead in paint. Other end uses will probably remain about equal to the 1976 levels. 
TABLE 3.6-5

\section{ESTIMATED 1987 LEAD CONSUMPTION}

$\begin{array}{lr}\text { Batteries } & 1,277,000 \text { ST } \\ \text { Other Metal Products } & 194,000 \text { ST } \\ \text { Gasoline Additives } & 100,000 \text { ST } \\ \text { Other Miscellaneous } & 269,000 \text { ST } \\ \text { Total } & 1,840,000 \text { ST }\end{array}$

Source: Arthur D. Little, Inc. 


\section{REFERENCES}

\section{REFERENCES: SECTION 3.2 FERROUS}

1 Steel and the Environment - A Cost Impact Analysis. Arthur D. Little, Inc., 1975.

2 AISI Annual Statistical Report, 1977.

3 Pietruch, W.E., and R.L. Deily, Steel Industry in Brief: Databook, U.S.A., 1977, Institute for Iron and Steel, 1977.

4 AISI Annual Statistical Report, 1976.

5 Classification hy Firm, 1977 Steel Industry Financial Analysis, Iron Age, April 4, $19^{\prime} 77$.

6 U.S. Department of Commerce, Bureau of Census, Current Industrial Reports, M33, 1955 1976.

7 Annual Survey of Manufacturers, 1976. Fuels and Electric Energy.

8 Annual Survey of Manufacturers - General Statistics for Industry Groups and Industries, Bureau of Census, 1976.

9 Foundry File. Penton Publications, 1977.

10 Ferroalloys - U.S. Bureau of Mines Mineral Yearbook, 1976.

11 Minorale Yearbonk - Iron and Steel. U.S, Bureau of Mines, 1976

12 World Steel Industry Data Handbook. 33 Metal Producing, 1978.

13 Casting Raw Stecl - U.S.A., R.L. Deily, I\&SM, December 1977, p. 31-33.

\section{REFERENCES: SECTION 3.3 ALUMINUM}

1 Aluminum Prices 1974-75, Staff Report, Council on Wage and Price Stability, Exccutive Office of the President. September 1976.

2 Census of Manufacturing Industries, 1972. U.S. Bureau of Census.

3 Aluminum Statistical Review 1976. Reported by the Statistical and Marketing Research Committee. Aluminum Association.

4 Recovery and Recycling of Automotive Aluminum, Society for Automotive Engineers, Inc., K.H. Dale, 1978. 
5 Economic Analysis of Pretreatment Standards for the Secondary Copper and Aluminum Subcategories of the Nonferrous Metals Manufacturing Paint Source Category, Report to . EPA by Arthur D. Little, Inc., October 1976.

6 Value of Product Shipments. Annual Survey of Manufacturers, 1976.

7 Environmental Considerations of Selected Energy Conserving Manufacturing. Process Options: Vol. VIII, Alumina/Aluminum Industry Report. Report to EPA by Arthur D. Little, Inc., December 1976.

8 The Recovery of Metal and Chemical Values from Aluminum Drosses. Alcan International, Ltd., Hans Spoel, 1975.

9 Furnace Dross - Its Formation and Recovery, Alumax, C.J. Moser.

10 Aluminum Mineral Commodity Profile, Bureau of Mines, May 1978.

11 Aluminum, Preprint from 1976 Minerals Yearbook. U.S. Bureau of Mines.

12 Aluminum Update, Journal of Metals, J.B. Ballance, October 1978, p. 36.

13 Aluminum Monthly, Mineral Industrial Surveys, Bureau of Mines, October 1978.

14 Aluminum, Minerals Yearbook, U.S. Bureau of Mines, 1972-1975.

\section{REFERENCES: SECTION 3.4 COPPER}

1 A Study to Identify Opportunities for Increased Solid Waste Utilization, Vol. II to VII, Report to the U.S. EPA by Battelle Columbus Labs, 1972.

\section{REFERENCES: SECTION 3.5 ZINC}

1 Energy Use Patterns in Metallurgical and Nonmetallic Processing (Phase 5 - Energy Data and Flowsheets, Intermediate Priority Commodities), U.S. Bureau of Mines, September 16, 1975.

2 Energy Use Patterns for Metal Recycling. Final Report to the U.S. Bureau of Mines by Arthur D. Little, Inc., January 1978.

3 U.S. Bureau of Mines Mineral Commodity Profiles Zinc, May 1978, MCP-12. 


\section{REFERENCES: SECTION 3.6 LEAD}

1 Calspan, Assessment of Industrial Hazardous Waste Practices in the Metal Smelting and Refining Industry, Volume II, Primary and Secondary Non-Ferrous Smelting and Refining. Report to the EPA. 


\subsection{EVALUATION OF RECYCLING TARGETS BY INDUSTRY GROUPS IN SIC 33}

\subsection{INTRODUCTION}

This section presents the evaluation of recycling targets for the following five major industry groups:

- Ferrous (includes iron and steel plants, ferrous foundries, and ferroalloy plants)

- Aluminum

- Copper

- Zinc

- Lead

The sixth industry group - Miscellaneous Nonferrous Metals Operations - is excluded from this section because the segments contained in this industry group are either not relevant to the recycling target estimation or their contribution to overall energy savings is insignificant.

Since the purpose of this project is to increase energy savings via the use of recoverable materials, it is important to remember that the ferrous industry (iron and steel, ferrous foundries, and ferroalloys), as defined here accounts for approximately $83 \%$ of the energy consumed in SIC 33 , aluminum for about $11 \%$, copper for about $3 \%$, lead and zinc each less than $1 \%$, and all others the balance. Therefore, most of the effort in the target evaluation is focused on the ferrous scrap users, followed by aluminum and copper.

The target evaluation procedure is based on a general methodology recommended by the DOE. It is described in detail in Section 2.

In this section, each industry group is discussed under the following general headings:

- Selection of recoverable materials

- Selection of process subdivisions for inclusion in the target

- Technical considerations

- Economic considerations

- Special considerations

- Target estimation

- Sensitivity of target to key factors

\subsubsection{Selection of Recoverable Materials}

The portions of each industry group to be included in the target estimation analysis are based on:

- Quality of the recoverahle material

- Dispersion of the recoverable material 
- Quantity of the recoverable material

- Potential new sources, and their quality, dispersion, quantity, etc.

- Changes in existing sources of the recoverable materials

According to the Department of Energy guidelines for this study, recoverable materials include:

- Wastes that contain materials listed in the NECPA

- Wastes from outside the United States

- Any wastes that may provide recoverable materials and replace virgin materials

Sources of recoverable materials do not include:

- Waste materials generated and introduced back into the process within the same plant.

- Waste materiáls not amung lhuse lisied in the Encrgy $\Lambda$ ct.

- Situations where a clear case can be made that the potential source will not be used as recoverable material by 1987 .

The Department of Energy guidelines are followed for all the five major industry segments. Two items for which a discriminatory evaluation procedure is followed are:

- Mine waste is excluded from our,analysis, except for the copper industry, even though the Energy Act includes mine waste as a recoverable material. The reason for doing this is that of all the mine wastes gencrated in the SIC 33 industry groups, only copper mine waste meets the Department of Energy's recoverable material selection criteria. Therefore, mine waste is not included in the analysis, except for copper.

- Waste material generated and introduced back in the process within the same plant is not included in the analysis, unless data was available from published sources or the trade associations. Data on dusts and sludges were generally not available and, therefore, these materials are not included in the analysis.

\subsubsection{Selection of Process Subdivisions for Inclusion in the Target}

For each industry group it is necessary to subdivide the industry on the basis of process or other industry classification. Fur example, the ferrous industry is eubdivided by proness herause the consumption of recuverable inaterial is proccss depondent. The aluminum industry, however, is subdivided into industry groups rather than by process because the consumption of recoverable. material is independent of the process (e.g., reverberatory furnace, crucible), but does depend on the industry groups (e.g., primary and secondary).

\subsubsection{Technical Considerations}

This section deals with three broad technical considerations related to recycling:

- Process Constraints - These relate to process factors that limit recycling. As an example, the scrap/hot melal ratio that can be proccssed in a copper converter and 
the basic oxygen furnace is limited because of heat balance considerations. In contrast, the reverberatory furnace and crucible in the aluminum industry can process $100 \%$ scrap.

- Product Quality Constraints - The use of recoverable material is also limited by the product specifications. As an example, an antimonial copper scrap with high tin and nickel content cannot be processed in a plant producing wirebars but could be acceptable in a plant making certain specific copper alloys which include antimony, nickel and tin.

- Recoverable Material Quality Constraints - The recoverable material quality constraints are indirectly related to Process and Product Quality constraints. The recoverable material chemical and physical qualities must be compatible with process requirements and product requirements.

\subsubsection{Economic Considerations}

In most industry groups, economic considerations are the governing facturs controlling recycling, rather than technical considerations. These have been discussed in Section 2. The approach used by Arthur D. Little, Inc., for the economic analysis differs somewhat from that in the Department of Energy guidelines. Arthur D. Little uses econometric techniques to estimate the supply of recoverable material in 1987. Most of the effort in econometric modeling is focused on the ferrous industry, followed by aluminum and copper. Details of the approach are discussed in Section 2.2.5. For lead and zinc, draft targets are developed on the basis of historical data and published forecasts of the future of the industry.

\subsubsection{Special Considerations}

This section discusses the circumstances and considerations related to recycling but not included in the sections on technological and economic considerations. An example of spccial consideration is the issue of municipal solid waste recovery of cans for the aluminum industry.

\subsubsection{Target Estimation}

In this section the method of target estimation and the estimated target are discussed. Because of the wide diversity in the industry segments, the quality of data available, and other factors, the target estimation procedures are not identical for all the five industry segments analyze. H. However, ovcry cffort has been inade to present the targets for individual industry segments in a similar format.

\subsubsection{Sensitivity of Target to Key Factors}

Because the development of a target depends on the interpretation and projections of the future, and because the projection of future conditions is based on numerous sources of data, many of which are conflicting, it is important lu know how inaccuracies in assumptions made of future conditions can affect the target. The section on sensitivity analysis attempts to address this problem. 


\subsection{FERROUS}

The evaluation of the recycling targets for the ferrous industry has been simplified by dividing the industry into the following segments:

- Iron and Steel

- Ferrous Foundries

- Ferroalloys

\subsubsection{Selection of Recoverable Materials}

\subsubsection{Iron and Steel}

The pussible sources of recoverable unaterials for the iron and steel segment can be grouped into four general categories:

- Ferrous scrap

- Mill scale

- Dust and sludge

- Slag

A brief description of the materials comprising each of these categories has been given in Scction 3.2.4 of this report. All the possible sources of recoverable materials for the iron and steel segment are listed in Table 4.2-1. This table indicates which of the materials have been selected for consideration in this study by meeting the criteria for inclusion as defined by the Department of Energy. The selection criteria are outlined in Section 4.1 .

Significant quantities of the three lypes of scrap mulerial (liomc, obnoloto and prnmpt) composing the ferrous scrap calegory are presently being ulilized as sourccs of recovered material within the iron and steel segment. This practice is expected to continue into the future, and therefore all three types of ferrous scrap arc included in the resycling target evaluation.

In the slag category, blast furnace slag and electric arc furnace slag were not selected for inclusion. Blast furnace slag is usually sold to slag processors who recover the iron from the slag by magnetic separation and sell this material, known as slag scrap, back to the iron and steel industry for reprocessing. Since slag scrap is included in the catogory of ferrnus scrap, blast furnace slag will not be considered separately. Electric furnace slag is rccycled to some extent in order to provide a proteclive slag layer in the furnace. It is not recycled as a source of iron and, therefore, does not meet the inclusion criteria. Basic oxygen and open hearth furnace slags are both processed to some degree to recover contained iron and the processed slag is either sold, dumped or used as a source of flux. These two types of slag provide iron units for recycle which will be included in the evaluation of the recycling target.

Mill scale containing over $50 \%$ iron is collected in the water pollution control facilities associated with primary reduction mills, continuous casters, and hot and cold rolling mills. Besides iron, these scales can contain small concentrations of chromium, coppcr, manganese, nickel, lead, and zinc. Mill scale may also contain over $1.0 \%$ oil and grease. These high oil and impurity contents limit their use in the sinter strand. However because of the contained iron units, mill scale is partially recycled to the sinter strand, the blast furnace, and all three types of 


\section{SELECTION OF RECOVERABLE MATERIALS} IRON AND STEEL SEGMENT

Recoverable Materials

Ferrous Scrap

Home

Prompt Industrial

obsolete

Mill Scale

Dust and Sludge

Blast Furnace

Basic 0xygen Furnace

Electric Arc Furnace

Open Hearth Furnace

Rolling Operations

Slag

Blast Furnace

Basic Oxygen Furnace

Electric Arc Furnace

Open Hearth Furnace
Does the Recoverable Material Meet the Criteria* for Inclusion?

Yes

No

$x$

$x$

$x$

$x$

$x$

$x$

$x$

$$
x
$$

$x$

$X$

$x$

$x$

* The criteria are outlined in Section 4.1. 
steelmaking furnaces, depending on the quality (oil and impurity content) of the scale. This material meets the inclusion criteria and, therefore, will be considered in the analysis.

Electric arc furnace (EAF) dusts and sludges have been excluded from consideration because they are not presently recycled except for isolated cases and are not expected to be recycled to any significant extent in the near future. These dusts and sludges contain measurable amounts of chromium, copper, manganese, nickel, lead and zinc. The "tramp" impurities severely inhibit the industry's ability to process electric furnace dust and sludges for their iron units. In addition, sintering plants, the usual processing route for dusts and sludges, are generally not located in the same plant as the EAF, thus precluding any simple "in-house" recycle scheme.

Primary reduction mills, continuous casting units, hot and cold rolling mills, tin plating mills, and galvanizing mills produce sludges from water pollution control operations at a rate ranging from 0.1 to $10 \mathrm{~kg} /$ metric ton of finished steel. ${ }^{(1)}$ In general, these sludges are not recycled because they contain significant amounts of oil and grease. For this reason, as well as the fact that they are generated in relatively small amounts, these sludges will not he considered in the analysis.

Blast furnace, basic oxygen furnace, and open hearth furnace dusts and sludges will be considered in the analysis. These materials are currently being recycled, some to agglomeration plants for the recovery of iron units and some to improve the permeability of the sinter products.

Recent consumption patterns (1970-1976) for the selected recoverable materials within the iron and steel segment are given in Table 4.2-2. Table 4.2-3 contains consumption data for various categories of purchased and home scrap.

\subsubsection{Ferrous Foundries}

Table 4.2-4 lists the potential sources of recoverable material for the ferrous foundry industry and identifies those that meet the criteria necessary for inclusion in this study. The criteria are described in Section 4.1. The recoverable materials are broadly classified into three categories:

- Scrap

- Dust and sludge

- Slag

Though foundry sand is an important material recycled in the ferrous foundry industry, it is excluded from this analysis because it does not contribute ferrous or metallic units and, therefore, does not relate to SIC, 33 .

Scrap is the most important source of recoverable material in the ferrous foundry industry. The various types of iron and steel scraps that are important recyclable materials are shown in Table 4.2-4. Home scrap consists of the risers and runners, skulls and reject castings generated in the foundries. In most foundries the home scrap is a major component of the charge to the melting furnace, in some instances as high as $50-70 \%$ of the metallic charge. 
TABLE 4.2-2

CONSUMPTION OF RECOVERABLE MATERIALS (1970-1976)

IRON AND STEEL SEGMENT

Type of

Quantity Consumed - Million Short Tons

Recoverable Material

1970

1971

1972

1973

1974

1975

1976

Serap:

Home*

Purchased**

46.36

42.61

44.43

50.41

47.42

40.06

43.46

22.96

22.01

28.99

32.06

33.65

22.78

24.97

TOTAL

69.32

63.69

73.42

82.47

81.07

62.84

68.43

Mill Scale

NA

NA

NA

NA

NA

NA

NA

3.23

2.88

2.58

2.29

2.36

2.00

2.45

Slag

NA

NA

NA

NA

NA

$6.8-9.6$

NA

*Home Scrap Production

$\div$ - Includes Prompt Industrial and Obsolete scrap

NA: Not Available

Sources: U.S. Bureau of Mines, Minerals Yearbooks, 1970-1976

AISI Annual Statistical Reports, 1970-1976 
TABLE $4.2-3$

\section{CCNSUMPTION D) SCRAP* BY GRADE $(1971-197 \epsilon)$}

IRJN AND STEEL SEGMENT

(Thousand Short Tons)

Type of Scrap

Carbon Steel:

Low phos. plate 5 punchings

Cut structural

No. 1 heavy melting

No. 2 heavy melting

No. 1 and EF buritles

$\stackrel{+}{\infty}$

No. 2 and other bundles

Turnings and borings

Slag scrap

Shredded or frag.

All other

Stainless Steel

Alloy Steel

Cast Iron **

Other Grades

TOTAL

$\begin{array}{rrrrrrr}1971 & 1972 & 1973 & 1974 & 1975 & 1976 \\ & & & & & \\ 362 & 538 & 532 & 761 & 733 & 987 \\ 389 & 525 & 782 & 657 & 478 & 393 \\ 27,178 & 27,751 & 30,375 & 28,274 & 22,205 & 23,984 \\ 3,061 & 3,362 & 4,008 & 4,135 & 3,064 & 3,421 \\ 5,559 & 6,746 & 7,574 & 7,656 & 7,597 & 8,870 \\ 2,709 & 2,997 & 3,549 & 3,656 & 2,324 & 2,584 \\ 1,632 & 1,753 & 1,392 & 2,185 & 1,608 & 1,339 \\ 2,942 & 3,076 & 3,658 & 4,052 & 4,082 & 4,180 \\ 1,172 & 1,507 & 1,778 & 2,332 & 2,014 & 2,064 \\ 13,666 & 15,058 & 17,491 & 15,027 & 11,711 & 12,933 \\ 768 & 930 & 1,036 & 1,2 C 2 & 687 & 1,020 \\ 2,340 & 2,450 & 2,399 & 2,313 & 1,869 & 1,829 \\ 5,068 & 5,234 & 6,364 & 5,359 & 3,275 & 3,770 \\ 673 & 1,481 & 959 & 1,473 & 1,189 & 1,053 \\ 64,619 & 73,408 & 82,467 & 81,074 & 62,836 & 68,427\end{array}$

* Includes home scrap.

** Includes ingot rold and stool scrap, machinery and cupola cast iron, cast iron borings and motcr blocks and other iron scrap.

Source: U.S. Bureau of Mines, Mineral Yearbook, 1971-1976 


\section{SELECTION OF RECOVERABLE MATERIALS}

\section{FERROUS FOUNDRY SEGMENT}

Does the Recoverable Material Meet The Criteria* for Inclusion?

Recoverable Material

$\underline{\text { Yes }}$

№

Scrap

Carbon Stee 1

$x$

- low phosphorus plate and punchings

- cut structural and plate

- No. 1 heavy melting steel

- No. 2 heavy melting steel

- No. 1 and electric furnace bundles

- No. 2 and other bundles

- turnings and borings

- slag scrap (Fe content)

- shredded or fragmentized

- all other carbon steel scrap

Stainless Steel

Alloy Steel (except stainless)

Cast Iron (includes borings)

Other Grades of Scrap

Ferrous Fraction of Municipal Solid Waste

Home Scrap

$x$

$x$

$x$

$x$

$x$

$x$

Dust and sludge

Cupola Dust

$x$

Electric Furnace Dust

$x$

Slag

Cupola Slag

$x$

Electric Furnace S1ag

Used Mold Materials

*The criteria are outlined in section 4.1 . 
Purchased scrap is most often obtained from scrap dealers, with smaller amounts sold directly by scrap generators. Iron foundries consume most of the iron scrap traded in the market. In addition, they purchase about an equivalent tonnage of steel scrap. Steel foundries buy largely steel scrap.

Of the various dusts and sludges generated in the ferrous foundry industry, the only dusts and sludges that have potential metal values are those that are recovered from the melting operations. Dusts and sludges from molding and coremaking have no ferrous units and, therefore, are not recoverable in the context of this study. The dust from the cupola melting furnace contains iron, but only in small concentrations. Because of its low iron content and because it contains small quantities of zinc, lead, and other undesirable impurities, cupola dust is not expected to be recycled for its ferrous. lead or zinc content by 1987. Therefore it is excluded from the analysis. Electric furnace dust presents the same problems as the cupola dust and, theretorc, does not meet the selection criteria outlined by the Department of Energy.

The two principal types of slags generated in the foundry industry are:

- Cupola slidg

- Electric furnace slag

Neither of these slag categories is expected to be a potential source of iron units in the near future (1987) because of technical and economic factors. Therefore, both of these slags will be excluded from further analysis. It should be noted, however, that a part of this slag is sold as ballast for road construction.

Recent consumption (1971-1976) of the selected recyclable materials within the ferrous foundry segment are shown in Table 4.2-5.

\subsection{I.3 Ferronallioys}

Kecyclable materials associated with ferroalloy smelting can be grouped into four cat.egories:

- Purchased ferrous scrap

- Ferroalloy home scrap

- Dust and sludge

- Slay

As shuwn in Table 4.2-6, only purchased ferrous scrap and electric arc furnace slag produced in ferromanganese production meet the selection criteria outlined in Section 4.1. Both of these are consumed in significant amounts and are expected to be in the future. Because the quantity of ferroalloy home scrap is very small, it will be excluded from this analysis. Ferrochromium, silicomanganese and other types of electric arc furnace slag are not presently being recycled and are not expected to be in the near future. These slags will therefore be excluded from the analysis. Slag, dust, and sludge from blast furnaces are not considered because blast furnacee are no longer used for ferroalloy production in the United States. Dust and sludge from electric arc furnaces are not considered for further study because they are not presently being recycled in significant quantities and are not expected to be in the near future. 
CONSUMPTION OF RECOVERABLE MATERIALS (1971-1976)

FERROUS FOUNDRY SEGMENT

Type of

Recoverable Material

Carbon Steel:

Low Phos.Plate \& Punchings

Cut Structural

No. 1 Heavy Melting

No. 2 Heavy Melting

No. 1 \& EF Bunales

No. 2 \& Other Bundles

$\stackrel{f}{亡}$
Turnings and Barings

Slag Scrap

Shredded and Frag.

A11 Other* *

Stainless Steel

Alloy Stee :

Cast Iron** *

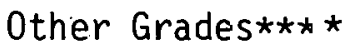

Total :
Home Scrap Plus Purchased Scrap Consumed in Iron and Steel Foundries (Thousand Short Tons). *

$1971 \quad \underline{1972} \quad \underline{1973} \quad \underline{1974} \quad \underline{1975} \quad \underline{1976}$

$\begin{array}{llllll}1476 & 1733 & 2047 & 1898 & 1767 & 1743\end{array}$

$\begin{array}{llllll}960 & 1216 & 1438 & 2150 & 1634 & 1818\end{array}$

$\begin{array}{llllll}496 & 580 & 711 & 743 & 652 & 623\end{array}$

$\begin{array}{llllll}218 & 60 & 188 & 122 & 203 & 190\end{array}$

$\begin{array}{llllll}417 & 475 & 496 & 642 & 460 & 482\end{array}$

$\begin{array}{llllll}480 & 686 & 625 & 658 & 347 & 441\end{array}$

$\begin{array}{llllll}680 & 687 & 802 & 781 & 766 & 831\end{array}$

$\begin{array}{llllll}21 & 23 & 16 & 34 & 38 & 50\end{array}$

$\begin{array}{llllll}482 & 555 & 639 & 917 & 733 & 935\end{array}$

$\begin{array}{llllll}2572 & 2900 & 2914 & 3352 & 2970 & 3496\end{array}$

\begin{tabular}{|c|c|c|c|c|c|}
\hline 197 & 39 & 38 & 83 & 100 & 71 \\
\hline 231 & 271 & 254 & 311 & 271 & 246 \\
\hline 9028 & 9840 & 10010 & 3774 & 4077 & 4627 \\
\hline 690 & 890 & 943 & 8838 & 5477 & 5929 \\
\hline 17948 & 19956 & 21122 & 24409 & 19495 & 21483 \\
\hline
\end{tabular}

* Includes miscallaneous scrap users.

** Includes "all other carbon steel", one foot and under (not bundles), and railroad rails.

*** Includes ingot mold and steel scrap, machinery and cupola cast iron, cast iron borings and motor blocks and other iron scrap.

$\star \star \star \star *$ Includes other iron scrap and other mixed scrap.

Source: U.S. Bureau of Mines, Minerals Yearbooks, 1971 - 1976 
TABLE 4.2- 6

SELECTION OF RECOVERABLE MATERIALS

\section{FERROALLOYS SEGMENT}

Does the Recoverable Material Meet the Criteria* for Inclusion?

Recoverable Material

Yes

No

Purchased Ferrous Scrap

$x$

Ferroalloy Home Scrap

$x$

51 ay

Blast rurnace

$x$

Electric Arc Furnace

Ferrochromium

$x$

Ferromanganese

$x$

Sil icomanganesé

Other

$x$
$x$
$x$
$x$

Dust and Sludge

Blast Furnace

Electric Arc Furnace

$x$

$x$

* The criteria is outlined in section 4.1 . 
Recent consumption (1970-1976) for the selected recyclable materials within the ferroalloys segment are given in Table 4.2-7.

\subsubsection{Selection of Process Subdivisions for Inclusion in the Target}

\subsubsection{Iron and Steel}

The structure of the iron and steel industry is such that, for the purposes of establishing a recycling target, it is most appropriate to subdivide the industry into unit operations. Reasons for this subdivision include:

- The principal industry associations, American Iron and Steel Institute (AISI) and Institute of Scrap Iron and Steel (ISIS) have traditionally followed a breakdown by unit operation in the collection of their data.

- Technological factors affecting recycling can be analyzed on a unit-by-unit basis.

- Relatively few unit operations are capable of processing recoverable materials. Thus, by dividing the industry into unit operations, it is possible to neglect those processes that do not directly affect the recycling target.

Recoverable materials can enter the steelmaking sequence at three points:

- Sinter strand (agglomeration facility)

- Blast furnace

- Steelmaking furnace (open hearth, basic oxygen, or electric arc)

The types of recoverable materials processed by each of these unit operations, are given in Table 4.2-8. As this table shows, sinter strands are capable of processing steelmaking furnace slag, mill scale, and blast furnace and steelmaking furnace dusts and sludges.

Blast furnaces can process ferrous scrap along with relatively small quantities of steelmaking furnace slag. Basic oxygen, electric arc and open hearth furnaces can recycle only ferrous scrap and mill scale. Open hearth furnaces can also process a portion of their own slag, but only for fluxing units and not iron units.

Table 4.2-9 presents quantitative data on the amounts of recoverable materials consumed in each unit operation in 1976. Recent consumption data for recoverable materials (1970-1976) on a unit-by-unit basis are given in Tables $4.2-10 \mathrm{~A}$ through $4.2-10 \mathrm{E}$.

\subsubsection{Ferrous Foundries}

The ferrous foundry industry can be segregated into two well-defined segments:

- Iron foundry industry

- Stccl foundry industry

This breakdown is chosen because the steel foundry industry is essentially $100 \%$ scrap-based, whereas the iron foundry industry consumes moderate amounts of pig iron besides scrap. Further, the Rureau of Mines puhlishes srrap data separately fon these two segments. 
TABLE 4.2-7

CONSUMPTION OF RECOVERABLE MATERIALS $(19701-1976)$

FERROALLOYS SEGMENT

Quantity Consumed (thousand short tons)

Type of

Recoverable Materia ${ }^{-} \quad \underline{1970} \quad \underline{1971} \quad \underline{1972} \quad \underline{1973} \quad \underline{1974} \quad \underline{1975} \quad \underline{1976}$

Purchased Ferrous Scrap* $\quad 573 \quad 515 \quad 558 \quad 557 \quad 505 \quad 426 \quad 422$

Electric Arc Furnace

Ferromanganese Slag** $\quad 301 \quad 274 \quad 288 \quad 246 \quad 196 \quad 207 \quad 174$

Sources:

* Ferroalloy praduction from U.S. Bureau of Mines Minerals Yearbooks, 1970-1976.

Ferrous scrap factor frcm a Predicast computer output, 1978, based cn U.S. Census data.

** Ferromanganese production statistics from U.S. Bureau of Mines Minerals Yearbooks, 1970-1976. Recycled slag factor frcm "Assessment of Industrial Hazardous Waste Practices in the Metal Smelting arid Refirirg Industry", Volume III, 1977. 
TABLE $4.2-8$

RECOVERABLE MATERIAL SOURCE - INDUSTRY MATRIX

IRON AND STEEL SEGMENT

Subdivision by Process

$\frac{\text { Ferrous Scrap }}{\text { Prompt }}-$ Mill Scale

Home Industrial Obsolete Rolling Mills

\section{sinter Plant \\ Elast Furnace \\ Easic Oxygen \\ $\stackrel{A}{i}$ Electric Arc \\ Cipen Hearth}

$\begin{array}{ll}x & \\ x & x \\ x & x \\ x & x\end{array}$

$\begin{array}{ll} & x \\ x & x \\ x & x \\ x & x \\ x & x\end{array}$

Types of Recoverable Materials

Source: Arthur D. Little, Inc. 
TABLE 4.2-9

CONSUMPTION OF RECOVERABLE MATERIALS BY PROCESS IN 1976

IRON AND STEEL SEGMENT

Type of Recoverable Material

(thousand shor: tors)

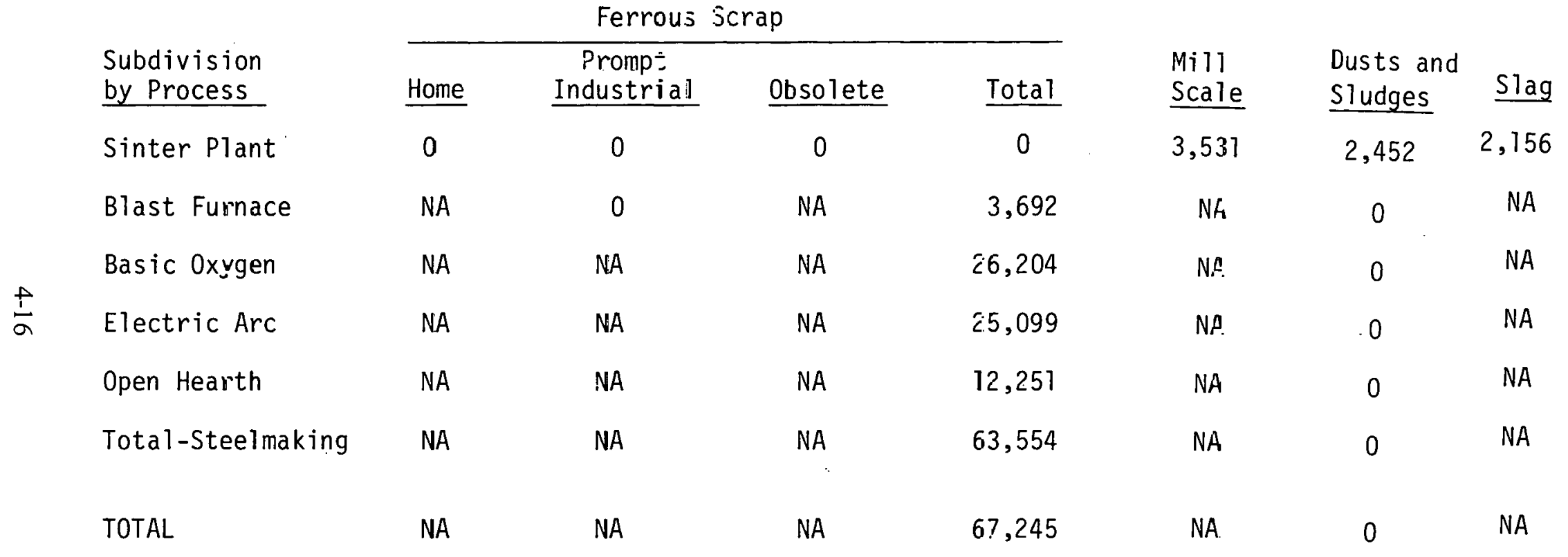

NA: Not available.

Source: AISI Annual Statistical Report, 1977. 
TABLE $4.2-10-A$

CONSUMPTION OF RECOVERABLE MATERIALS BY THE SINTER PLANT (1970-1976) IRON ANU STEEL SEGMENT Material

Mil1 Scale

Dust \& Sludge

$\stackrel{t}{ \pm}$

Blast Furnace
Type of Recoverable
Basic 0xygen Furnance

Open Hearth

Total

Slag

Basic 0xygen Furnace

Open Hearth Furnace

Total*

\begin{tabular}{lllllll}
\hline \multicolumn{8}{c}{ Million Net Tons } \\
\hline 1970 & 1971 & 1972 & 1973 & 1974 & 1975 & 1976
\end{tabular}

$\begin{array}{lllllll}3.695 & 3.324 & 3.464 & 4.031 & 3.799 & 3.211 & 3.51\end{array}$

NA NA NA NA NA NA NA NA

$\begin{array}{llllll}N A & N A & N A & N A & N A & N A\end{array}$

NA NA NA NA NA NA NA NA

$\begin{array}{lllllll}3.228 & 2.877 & 2.575 & 2.289 & 2.357 & 1.999 & 2.452\end{array}$

$\begin{array}{lllllll}\text { NA } & \text { NA } & \text { NA } & \text { NA } & \text { NA } & \text { NA } & \text { NA } \\ \text { NA } & \text { NA } & \text { NA } & \text { NA } & \text { NA } & \text { NA } & \text { NA } \\ 0.625 & 0.934 & 1.251 & 1.770 & 1.699 & 1.467 & 2.156\end{array}$

*Cinder and slag.

NA: not available

Source: AISI Annual Statistical Report, 1970-1977. 
TABLE $\quad$ a.2-10-B

CONSUMPTICN OF RECOVEYABLE MATERIALS BY THE BLAST FURNACE (1970-1976) IRON AND STEEL SEGMENT

Type of Recoverable Material

\section{Ferrous Scrap}

Home

Total Scrap*

Mill Scale

Slaq

$\frac{f}{\infty}$ Basic Oxygen Open Hearth

*Includes home and obsolete scrap.

NA: Not Availabile

Source: AISI Annual Statistical Report, 1970-1977. 
TABLE 4.2-10-C

CONSUMPTION OF RECOVERABLE MATERIALS BY THE BASIC OXYGEN FURNACE (1970-1976) IRON AND STEEL SEGMENT

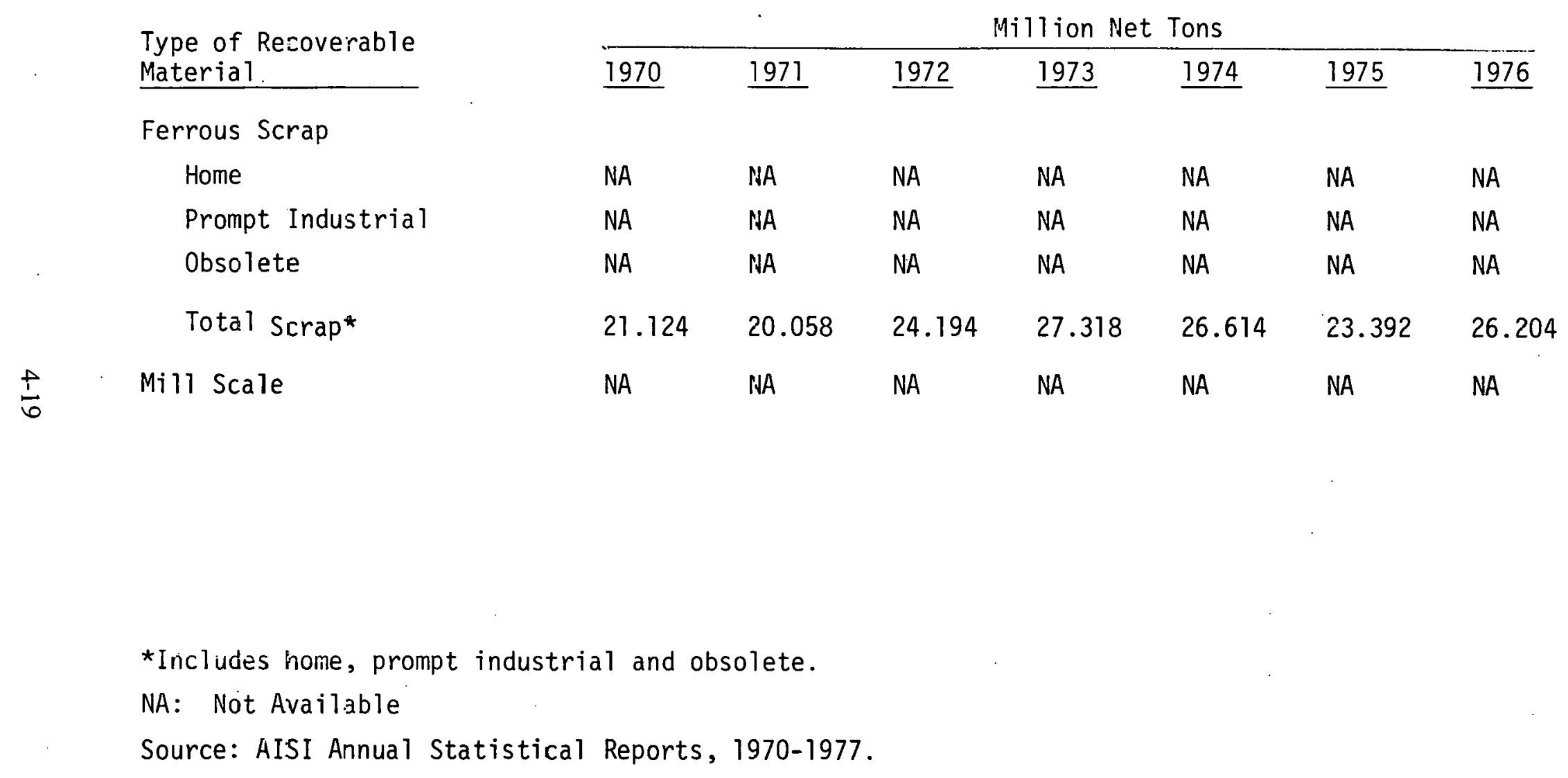


TABLE $4.2-10-2$

CONSLMPTION OF RECOVERABLE MATERIALS BY THE ELECTRIC ARC FURNACE (1970-1976)

IRON AND STEEL SEGMENT

\begin{tabular}{|c|c|c|c|c|c|c|c|}
\hline \multirow{2}{*}{$\begin{array}{l}\text { Type of Recoveratle } \\
\text { Material }\end{array}$} & \multicolumn{7}{|c|}{ Million Net Tons } \\
\hline & 1970 & 1371 & 1972 & 1973 & $\underline{1974}$ & 1975 & 1976 \\
\hline Ferrous Scrap & & & & & & & \\
\hline Home & NA & WA & NA & $N A$ & IJA & NA & $N A$ \\
\hline Prompt Industrial & NA & MA & NA & NA & MA & NA & NA \\
\hline Obsolete & NA & WA & $N A$ & NA & MA & NA & NA \\
\hline Total Scrap* & 18.834 & 20.150 & 24.886 & 28.615 & 29.710 & 23.010 & 25.099 \\
\hline Mill Scale & NA & MA & NA & NA & MA & NA & NA \\
\hline
\end{tabular}

*Includes home, prompt industrial and obsolete scrap.

NA: Not Available

Source: AISI Arnual Statistical Reports, 1970-1977. 
TABLE 4.2-10-E

CONSUMPTION OF RECOVERABLE MATERIALS BY THE OPEN HEARTH FURNACE (1970-1976)

IRON AND STEEL SEGMENT

\begin{tabular}{|c|c|c|c|c|c|c|c|}
\hline \multirow{2}{*}{$\begin{array}{l}\text { Type of Recoverable } \\
\text { Material }\end{array}$} & \multicolumn{7}{|c|}{ Million Net Tons } \\
\hline & 1970 & 1971 & 1972 & 1973 & 1974 & 1975 & 1976 \\
\hline \multicolumn{8}{|l|}{ Ferrous Scrap } \\
\hline Home & NA & NA & NA & NA & NA & NA & $\mathrm{NA}$ \\
\hline Prompt Industrial & NA & NA & NA & NA & NA & NA & NA \\
\hline Obsolete & NA & NA & NA & NA & NA & $N A$ & NA \\
\hline Total Scrap* & 21.935 & 18.572 & 18.637 & 20.419 & 19.005 & 11.669 & 12.251 \\
\hline Mill Scale & NA & NA & NA & NA & NA & NA & NA \\
\hline
\end{tabular}

*Includes home, prompt industrial and obsolete scrap.

NA: Not Available

Source: AISI Annual Statistical Reports, 1970-1977. 
The industry subdivisions and sources of recovered materials are summarized in Table 4.211 with the quantities of recoverable materials consumed by the ferrous foundries in 1976 . Table 4.2-12 presents the consumption data (1971-1976) of various types of scrap used in the iron and steel foundries.

TABLE $4.2-11$

CONSUMPTION OF SCRAP - 1976

FERROUS FOUNDRY SEGMENT*

Industry Subdivision

Scrap Consumed (thousand short tons)

Gray Iron

Ductile Iron

Malleable Iron

Home Scrap Purchased Scrap**

Steel Castings

*Includes miscellaneous scrap users.

**Includes prompt industrial and obsolete scrap.

Source: U.S. Bureau of Mines, Mineral Yearbook, 1976.

\subsubsection{Ferroalloys}

For the purpose of establishing a recycling target, the ferroalloy industry is best divided into sections according to the type of ferroalloy produced. Reasons for this are:

- Avallable dàta are broken down by type of ferroalloy.

- Recycle of slag is dependent on type of ferroalloy.

Amounts of recoverable materials consumed in 1976 are shown in Table 4.2-13. Ferrochromium, ferrochromanganese, and ferrosilicon furnaces consume ferrous scrap. A part of ferromanganese slag is recycled to silicomanganese furnaces.

\subsubsection{Technical Considerations}

Technulugical considerations governing the recycling of recoverable materials include constraints of process and product quality and limitations of recoverable material. In general, the former establish the limitations of recoverable material quality, which, in turn, determine the amounts of recoverable material that can be recycled. In this section, technological factors affecting recycle within the ferrous industry will be described. 
TABLE 4.2-12

CONSUMPTION OF SCRAP* (1971-1976)

FERROUS FOUNDRY SEGMENT

Type of Scrap

Carbon Steel

Low Phosphorus Plate and Punchings

Cut Structural

No. 1 Heavy Melting

No. 2 Heavy Melting

No. 1 and Electric Furnace Bundles

^o. 2 and Other Bundles

Turnings and Borings

slag Scrap

$\underset{\sim}{\stackrel{t}{*}}$

\section{Shredded or Fragmentized}

f.11 Other

Staintess Steel

Allay Steel (except stainless)

Cast Iron

Other Grades

TOTAL
Steel Foundries

$1971 \quad \underline{1972} \quad \underline{1973} \quad \underline{1974} \quad \underline{1975} \quad \underline{1976}$

$\begin{array}{rrrrrr}643 & 637 & 800 & 840 & 878 & 778 \\ 166 & 178 & 236 & 288 & 248 & 230 \\ 241 & 203 & 226 & 255 & 244 & 211 \\ 2 & 1 & 13 & 37 & 49 & 56 \\ 70 & 107 & 73 & 68 & 54 & 58 \\ 19 & 15 & 18 & 15 & 11 & 4 \\ 66 & 70 & 80 & 74 & 83 & 81 \\ 3 & 6 & 3 & 7 & 14 & 11 \\ 61 & 53 & 77 & 74 & 81 & 96 \\ 830 & 797 & 879 & 907 & 947 & 870 \\ 193 & 2.6 & 25 & 39 & 68 & 51 \\ 117 & 127 & 137 & 167 & 181 & 173 \\ 277 & 295 & 285 & 118 & 123 & 119 \\ 99 & 99 & 97 & 274 & 192 & 113 \\ & & & & & \\ 2787 & 2664 & 2949 & 3269 & 3173 & 2851\end{array}$

Iron Foundries **

\begin{tabular}{rrrrrr}
\hline 1971 & 1972 & $\underline{1973}$ & $\underline{1974}$ & $\underline{1975}$ & $\underline{1976}$ \\
& & & & & \\
833 & 1046 & 1247 & 1058 & 889 & 965 \\
974 & 1038 & 1202 & 1862 & 1386 & 1588 \\
255 & 377 & 485 & 488 & 408 & 412 \\
216 & 59 & 175 & 85 & 154 & 134 \\
347 & 308 & 423 & 574 & 406 & 424 \\
461 & 671 & 607 & 543 & 336 & 437 \\
614 & 617 & 722 & 707 & 683 & 750 \\
18 & 17 & 13 & 27 & 24 & 39 \\
421 & 502 & 562 & 943 & 652 & 839 \\
1742 & 2103 & 2035 & 2445 & 2023 & 2626 \\
4 & 13 & 13 & 44 & 32 & 20 \\
114 & 144 & 117 & 144 & 90 & 73 \\
8751 & 9545 & 9725 & 3656 & 3954 & 4508 \\
591 & 791 & 846 & 8564 & 5285 & 5816 \\
& & & & & \\
15161 & 17292 & 18173 & 21140 & 16322 & 18632
\end{tabular}

* Includes home and purchased scrap.

** Includes miscellaneous scrap users.

Source: U.S. Bureau of Mines Minerals Yearbooks, 1971-1976. 
TABLE $4.2-13$

$\frac{\text { CONSUMPTION OF RECOVERABLE }}{\text { FERROALLOY SEGMENT }}$

Subdivision by Type of Ferroalloy

Ferrochromium

Ferromanganese

Silicomanganese

Ferrosilicon

Scrap
Home
(Ferroalloy
Scrap)

NA

NA

NA

$13.0^{*}$

NA
Scrap

short tons)

Purchased
(Ferrous
Scrap)

Total

Scrap

NA

NA

NA

$271.0 *$

$258.0 *$

NA.

$422.0 *$
Slag

$\underline{F e C r} \quad \underline{F e M n}$

TOTAL

$N A=$ not available.

* Predicast Data Base, 1978.

** Calspan, Assessment of Industrial Hazardous Waste Practices in the Smelting and Refining Industry, Volume III, 1977.

\subsubsection{Process Constraints}

\subsection{Iron and Steel}

Operations in the iron and steel segment capable of processing recoverahle material include the sinter strand (agglomeration facility), the blast furnace, and the steelmaking furnaces: the open hearth, basic oxygen, and electric arc. The ability of each of these operations to handle recoverable materials depends on such process constraints as energy availability, equipment design, process flexibility, and pollution control. Process constraints for each of these operations are discussed below.

Sinter Strand: In general, sinter strands are incapable of removing impurities; any tramp element entrained in the feed will necessarily report to the discharge. However some elements such as zinc and sulfur and oils can be partially removed. Therefore, the extent to which mill scale, dust and sludge, and slag can be recycled to the sinter plant is determined primarily by the tramp impurities content of these materials. In order for the contaminated material to be recycled, the impurities will have to be removed or diluted in downstream processing. An additional factor is that recycling of in-plant fines (mainly dusts and sludges) to this unit can increase its pollution load in an unacceptable manner. ${ }^{(2)}$ 
Blast Furnace: The blast furnace has severe limitations on the chemical specifications of its feedstock; carbon is an asset in any material added to the burden, but zinc and lead must be limited carefully. Physical strength, reducibility, and softening behavior of the iron-bearing constituents of the burden must also meet high standards.

The most troublesome component of residues and scrap recirculated to the blast furnace is zinc. This element is highly detrimental to the furnace and tends to build up in the system. Other undesirable impurities include phosphorus, which will report to the hot metal and, therefore, requires incremental refining operations in subsequent operations; and lead, which is harmful to hearth bottoms.

Open Hearth Furnace: The open hearth furnace is probably the most flexible processing unit within the iron and steel industry for the recycling of recoverable materials. The type and composition of material charged to the open hearth furnace can be varied substantially. However, certain limiting relations among the elements of the charge must be observed. Elements such as copper and nickel, which are not oxidized or eliminated by the reaction in an open hearth process, may be introduced into the furnace only to the extent to which they are permissible in the finished steel. Small amounts of zinc or lead can be included in the charge since they will be readily volatilized at steelmaking temperatures. However, as with blast furnaces, these elements are detrimental to the furnace. A list of elements that report primarily to the slag (oxidation) and the metal in open hearth furnaces is given in Table 4.2-14.

Basic Oxygen Furnace: Because the basic oxygen converter does not rely on external sources of energy, the quantity of ferrous scrap it can process is limited by the amount of energy available for melting. In current practice, BOF's are operated with $20-30 \%$ scrap in the charge; $30 \%$ is generally recognized as the upper limit for normal operations. The "normal" operation is accomplished without the addition of fuel energy to the BOF or to the scrap.

Unlike the open hearth and the electric furnaces, the BOF utilizes scrap not only as a source of iron, but also as a coolant for controlling temperature. Consequently, the proportion of scrap used cannot be arbitrarily changed without adjusting other variables to maintain the thermal balance. Figure 4.2-1 is a theoretical presentation of how the percentage of scrap in the metallic charge can be increased by increasing the temperature of the hot metal. Alternate means of increasing scrap use include:

- Reducing heat losses of the process

- Adding external fuel to the process

- Raising the temperature of any and, all reactants

Of these alternatives, retrofitting for scrap preheating is considered the most practical. However it slows down production and its economics depend on scrap and fuel prices and site specific factors. Although preheating is not common at present, certain BOF shops have shown the ability to operate at almost $45 \%$ scrap using this method. ${ }^{(16)}$ The extent to which scrap preheating gains acceptance by the iron and steel industry will depend upon the future availability and prices of ferrous scrap and of energy.

Process constraints for the BOF, other than its thermal requirements, are similar to those for the open hearth furnace. 
TABLE $4.2-14$

DISTRIBUTION OF ELEMENTS BETWEEN SLAG AND METAL IN AN OPEN HEARTH FURNACE

\begin{tabular}{|c|c|c|c|c|}
\hline & $\begin{array}{l}\text { Elements Primarily } \\
\text { Reporting to the Slag } \\
\end{array}$ & $\begin{array}{l}\text { Elements [istributed } \\
\text { Between } \leq 1 \mathrm{ag} \text { and Metal }\end{array}$ & $\begin{array}{l}\text { Elements Primarily } \\
\text { Reporting =o Metal } \\
\end{array}$ & $\begin{array}{l}\text { Elements El iminated } \\
\text { From Slag and Metal } \\
\end{array}$ \\
\hline & Silicon & Mangariese & Cosper & Zinc \\
\hline & Aluminum & Phosphorus & Nicke ${ }^{-}$ & Cadmium \\
\hline & Titanium & Sulfur & Tin & Lead \\
\hline & Zirconium & Chramium & Mo l ybdenum & \\
\hline & 3oron & & Cobal: & \\
\hline & Vanadium & & Tungsten & \\
\hline & & & $\left(\right.$ Arsen $\left.{ }^{\circ} \mathrm{c}\right)$ & \\
\hline & & & (Antimony) & \\
\hline & ()$=$ Probably & & & \\
\hline & Source: AIME, Basic & rth Steelraking, 1951. & $\therefore$ & \\
\hline
\end{tabular}


Basis:

Normal 2400 F Hot Metal Uses 25\% Scrap

Steel Tapping Temperature is $2925 \mathrm{~F}$.

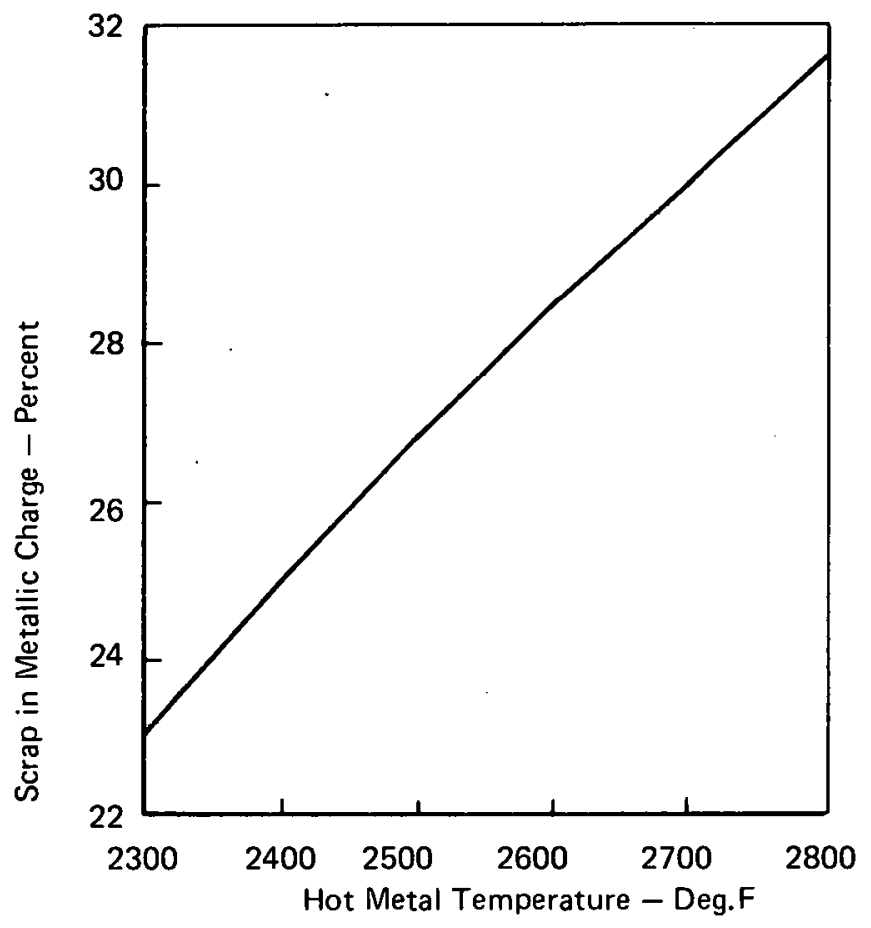

Source: Iron \& Steel Engineer, June 1963, page 68.

FIGURE 4.2-1 HOT METAL TEMPERATURE VS. \% OF FERROUS SCRAP IN METALLIC CHARGE 
Electric Furnaces: Most electric furnace installations actually operate on $100 \%$ scrap. The extent to which various types of scrap can be utilized is determined primarily by their contained impurities and the compositional requirement of the steel product.

\subsection{Ferrous Foundries}

The principal melting methods used in the ferrous foundry industry have been discussed in Section 3.2.3.2. The major processes employed are:

\section{Process}

Cupola

Electric Arc

Induction
Iron Foundries

$\mathrm{X}$

$\mathrm{X}$

$\mathrm{X}$

\section{Steel Foundries}

$\overline{\mathrm{X}}$

The cupola furnace usually operates with a scrap charge plus pig iron. The amount of pig iron in the charge is based on the quality of iron required and the quality of the scrap charged to the furnace.

Because steel scrap rcquires a higher melting temperature than iron scrap, the amount of steel scrap that can be charged to a cupola is restricted. In recent years, introduction of hot blast cupolas and oxygen enrichment with their higher heating capability have made feasible the use of an increased steel scrap content. The cupola cannot handle recyclable materials containing large quantities of non-volatile impurities, e.g., copper, aluminum, and tin. For efficient melting and handling, very large scrap is undesirable for the cupola.

The electric arc and induction melting furnaces are $100 \%$ scrap based melting operations. The electric arc furnace can perform some refining operations and, therefore, can handle a wider variety of scrap than the cupola. The induction furnace, on the other hand, can only handle scrap close to the composition of the final metal alloy. Both the electric arc and induction furnaces achieve high melting temperatures and can, therefore, melt $100 \%$ steel scrap charges.

\subsection{Ferroalloys}

The principal process constraint on the type of scrap that can be recycled is the physical form. The amount of scrap consumed is dependent on the ore grade and ferroalloy specification.

Ferromanganese slag can be recycled only if the plant has an integrated silicomanganese operation. The amount of ferromanganese slag that can he recycled to silicomanganese furnaces is limited by the ferromanganese slag composition, the grade of silisnmanganese renuiren, plant. specific considerations and the prevailing economics of the overall integrated operation.

\subsubsection{Quality Constraints}

\subsection{Iron and Steel}

In the iron and steel industry only three unit operations are capable of processing recoverable materials: agglomeration, smelting iron ore, and steelmaking. The products (sinter or briquettes, pig iron, and steel, respectively) of these processes must meet independent composi- 
tional and physical specifications. The ability of the products to do so is dependent on the raw materials entering each process and on the process itself. In this section, the compositional limits for the three types of products are given.

Agglomerated Products: Among the primary reasons for using sinter or briquettes is an improved burden permeability and improved gas-solid contact in order to lower blast furnace coke rates and increase the rate of reaction. Agglomeration is also used to lessen the amounts of fine materials entering into the furnace and, therefore, enhance their utilization. Furthermore, agglomerated products can be substituted for lump ores in steelmaking furnaces.

A good agglomerate should "contain $60 \%$ or more of iron, a minimum of material less than $1 / 4$ inch in size and a minimum of material larger than $1 / 2$ inch."(3) The agglomerate should be strong enough to withstand degradation during handling and shipment so as to arrive at the furnace with at least $85 \%$ of the material larger than $1 / 4 \mathrm{inch}$. Within the furnace, the agglomerate must be able to withstand the high temperature and degradation forces without slumping or decrepitating. The agglomerate must also reduce at a satisfactorily high rate.

Pig Iron (for Steelmaking): Unlike agglomerated products, which are restricted as to physical properties, iron for steelmaking is constrained by chemical composition limits. These limits depend to some extent on the type of steelmaking process for which the iron is destined. The allowable composition ranges for the most important impurities in pig iron for several steelmaking processes are given in Table 4.2-15. Electric furnace steelmaking is not listed because of the relatively minor amounts of pig iron and hot metal charged to such furnaces.

Raw Steel: Each of the many types of raw steel produced by the iron and steel industry has narrow composition limits. Because of the large number of steels produced, these limits are not reproduced here. The interested reader is referred to such sources as AISI's "Steel Products Manual," or "The Making, Shaping and Treating of Steel," by United States Steel Corporation. The relationship between the compositional limits and the impurities contained in recoverable materials charged to the steelmaking furnace is discussed in Section 4.2.3.3.1.

\subsection{Ferrous Foundries}

Table 4.2-16 shows the compositional constraints for the products produced in the iron and st.eel foundries. In order to meet the casting grade chemical specifications, the recoverable material (scrap) that can be charged to the melting furnace is somewhat limited. For example, ductile iron castings usually require a good quality control on the metal composition and, therefore, on the scrap that can be consumed. Similarly, alloy castings require good control of impurities that might be introduced via scrap.

Each foundry has its own set of casting quality requirements based on established customer demand and product specifications. Therefore, the mix of scrap used from foundry to foundry can vary significantly.

\subsection{Ferroalloys}

Specifications on ferroalloy composition are shown in Table 4.2-17. These specifications may control the type of ferrous scrap used in the ferroalloy production. 
TABLE $4.2-15$

COMPOSITION RANGES OF IRON FOR STEELAP.KING.

\begin{tabular}{|c|c|c|c|c|c|}
\hline \multirow[t]{2}{*}{ Type } & \multicolumn{5}{|c|}{ Composition Range (\%) } \\
\hline & $\underline{\text { Silicon }}$ & Sulphur & Phrosphorus & Manganese & Total Carbon ${ }^{*}$ \\
\hline $\begin{array}{l}\text { Basic Fig - Northern } \\
\text { In steps of }\end{array}$ & $\begin{array}{l}1.50 \\
0.25\end{array}$ & $0.05 \max$ & $0.400 \max$ & $\begin{array}{c}1.01-2.00 \\
0.50\end{array}$ & $3.5-4.40$ \\
\hline $\begin{array}{l}\text { Basic Pig - Soutrern } \\
\text { In steps of }\end{array}$ & $\begin{array}{l}1.50 \max \\
0.25\end{array}$ & $0.05 \max$ & $\begin{array}{c}0.700-0.900 \\
-\end{array}$ & $\begin{array}{c}0.40-0.75 \\
-\end{array}$ & $\begin{array}{c}3.5-4.40 \\
-\end{array}$ \\
\hline Acid Pig - Besserrer & $1.00-2.25$ & C.045 max & $0.34-0.135$ & $0.50-1.00$ & $4.15-4.40$ \\
\hline Acid Pig - Open Hearth & $0.70-1.50$ & G.045 $\max$ & Unter 0.05 & $0.50-2.50$ & $4.15-4.40$ \\
\hline Oxygen Steelmaking Pig & $0.20-2.10$ & $0.05 \max$ & $0.400 \max ^{\star \star}$ & $0.40-2.50$ & $3.5-4.40$ \\
\hline
\end{tabular}

*Carban not specified.

**Up to 2.00 percent phosphorus may be used by double slagging in the Jasic oxygen furnace.

Source: "The Making, Shaping \& Treating of Stee1," United States Steel Corp., gth edition. 
TABLE $4.2-16$

\section{FERROUS FOUNDRY SPECIFICATIONS}

\begin{tabular}{|c|c|c|c|c|c|}
\hline Type of Casting & Silicon & $\frac{\text { Com }}{\text { Carbon }}$ & $\frac{\%}{\text { sülfur }}$ & Phosphorus & Manganese \\
\hline Gray Iron & $1.0-3.0$ & $2.5-4.0$ & $0.02-0.25$ & $0.05-1.0$ & $0.25-1.0$ \\
\hline White Iron & $0.5-1.9$ & $1.8-3.6$ & $0.06-0.20$ & $0.06-0.18$ & $0.25-0.80$ \\
\hline Malleable Iron & $1.10-1.60$ & $2.00-2.60$ & $0.04-0.18$ & $0.18 \max$ & $0.20-1.00$ \\
\hline Ductile Iron & $1.8-2.8$ & $3.0-4.0$ & $0.03 \max$ & $0.10 \max$ & $0.10-1.00$ \\
\hline Steel & $0.2-0.8$ & $0.20-0.50$ & $0.06 \max$ & $0.05 \max$ & $0.5-1.0$ \\
\hline
\end{tabular}

Sources: American Foundrymen's Society, Principles of Metal Casting, 1955, Gray and Ductile Iron Founders' Society, Iron Cástings Hándbook, 1971. 
TABLE $4.2-17$

FERROALLOY SPECIFICATIONS

Ferroalloy

Composition, \%

\begin{tabular}{|c|c|c|c|c|c|c|c|}
\hline \multirow{2}{*}{\multicolumn{2}{|c|}{ Ferrochromium: }} & \multirow[t]{2}{*}{ Silicon } & \multirow[t]{2}{*}{ Carbon } & \multirow[t]{2}{*}{ Sulfur } & \multirow[t]{2}{*}{$\begin{array}{l}\begin{array}{l}\text { Phos- } \\
\text { phorus }\end{array} \\
\end{array}$} & \multirow[t]{2}{*}{ Manganese } & \multirow[t]{2}{*}{ Chromium } \\
\hline & & & & & & & \\
\hline High Carbon & $\begin{array}{l}A \\
B \\
C\end{array}$ & $\begin{array}{c}6.0-14.0 \\
3.0\end{array}$ & $\begin{array}{l}6.0-8.0 \\
4.0-6.0 \\
4.0-9.5\end{array}$ & $\begin{array}{l}0.040 \\
0.040 \\
0.060\end{array}$ & $\begin{array}{l}0.030 \\
0.030 \\
0.030\end{array}$ & $\begin{array}{l}0.75 \\
0.75 \\
0.75\end{array}$ & $\begin{array}{l}52.0-58.0 \\
55.0-64.0 \\
62.0-72.0\end{array}$ \\
\hline Low Carbon & $\begin{array}{l}A \\
B \\
C \\
D\end{array}$ & $\begin{array}{c}1.0-8.0 \\
1.0 \\
1.0 \\
1.0\end{array}$ & $\begin{array}{l}0.025 \\
0.025 \\
0.050 \\
0.75\end{array}$ & $\begin{array}{l}0.025 \\
0.025 \\
0.025 \\
0.025\end{array}$ & $\begin{array}{l}0.030 \\
0.030 \\
0.030 \\
0.030\end{array}$ & $\begin{array}{l}0.75 \\
0.75 \\
0.75 \\
0.75\end{array}$ & $\begin{array}{l}60.0-67.0 \\
67.0-75.0 \\
67.0-75.0 \\
67.0-75.0\end{array}$ \\
\hline $\begin{array}{l}\text { Vacuum Low } \\
\text { Carbon }\end{array}$ & $\begin{array}{l}E \\
F \\
G\end{array}$ & $\begin{array}{l}2.0 \\
2.0 \\
2.0\end{array}$ & $\begin{array}{l}0.020 \\
0.010 \\
0.050\end{array}$ & $\begin{array}{l}0.030 \\
0.030 \\
0.030\end{array}$ & $\begin{array}{l}0.030 \\
0.030 \\
0.030\end{array}$ & $\begin{array}{l}0.75 \\
0.75 \\
0.75\end{array}$ & $\begin{array}{l}67.0-72.0 \\
67.0-72.0 \\
63.0-68.0\end{array}$ \\
\hline Nitrogen Bea & ring & 1.0 & 0.10 & 0.025 & 0.030 & 0.75 & $62.0-70.0$ \\
\hline
\end{tabular}

Ferromanganese:

Standard A

$\begin{array}{ll}\text { A } & 1.2 \\ \text { B } & 1.2 \\ \text { C } & 1.2\end{array}$

$1.2 \quad 7.5$

0.050

0.35

78. 0-82.0

0.50

7.5

0.050

0.35

$76.0-78.0$

0.50

7.5

0.050

0.35

$74.0-76.0$

0.50

Medium Carbon $A$

1.0

1.5

0.020

0.30

$80.0-85.0$

0.50

1.5

0.020

0.30

$80.0-85.0$

0.50

1.50 .020

0.30

80.0-85.0

0.50

0.70
0.35

0.020

0.30

$80.0-85.0$

0.50

Nitrided 1.5

1.5

0.30

75-80

0.50

Low Carbon

$\begin{array}{ccc}\text { A } & 2.0 & .10-.75 \\ \text { B } & 5.0-7.0 & 0.75\end{array}$

0.020

0.20

85. 0-90.0

0.50

0.020

0.30

$80.0-85.0$

0.50

Ferrosilicon:

Steelmaking

$$
\begin{array}{ll}
\text { A } & 92.0-95.0 \\
\text { B } & 83.0-88.0 \\
\text { C } & 74.0-79.0 \\
\text { D } & 65.0-70.0 \\
\text { E } & 47.0-51.0 \\
\text { F } & 20.0-24.0 \\
\text { G } & 14.0-17.0
\end{array}
$$

0.10

0.025

0.025

0.030

0.25

0.35

0.15

0.025

0.035

0.40

0.035

0.10

0.025

0.040

0.10

0.025

0.120

0.50

0.025

0.120

0.50

0.75

0.025

1.00

0.25

0.25

0.30

0.50

0.50

1.25

Silicomanganese:

Standard

$$
\begin{array}{ll}
\text { A } & 18.5-21.0 \\
\text { B } & 16.0-18.5 \\
\text { C } & 12.5-16.0
\end{array}
$$

1.5

0.04

0.20

65. 0-68.0

0.50

2.0

0.04

0.20

$65.0-68.0$

0.50

$\begin{array}{ll}3.0 & 0.04\end{array}$

0.20

$65.0-68.0$

0.50

Source: American Society of Testing and Materials, Annual Book of ASTM Standards, 1977 


\subsubsection{Recoverable Materials Constraints}

Before a recoverable material can be utilized (recycled) in a given unit operation, its quality with respect to physical characteristics and chemical composition must conform to the specifications required by the processing unit and by the products produced. In this section, the physical and chemical requirements for the recoverable materials within the ferrous industry are described.

\subsection{Iron and Steel}

Ferrous Scrap: Approximately $30 \%$ of the raw steel produced by current industry practices is recycled as home scrap, ${ }^{(4)}$ and about $70 \%$ of this is charged to the furnaces with only minimal preparation. In general, the only processing required for the remaining $30 \%$ is to cut it into manageable pieces.

Purchased scrap, composed of prompt industrial and obsolete scrap, cannot be recycled as readily as home scrap. Purchased scrap can be both physically and chemically heterogeneous and, therefore, must be segregated and prepared to conform to specification.

The ideal bulk density of scrap for steelmaking depends on the working conditions of each steel mill where scrap must be charged. Charging a mixture of various kinds of scrap, heavy and small size scrap, can be used to fill voids. Melting the scrap will be faster if the pieces present a large surface area. Unfortunately, the loss by oxidation increases with surface area. With turnings or shredder scrap, the upper part of the bath can weld together, and melting the material then becomes more difficult.

For electric furnaces producing unalloyed carbon steel, thickness of individual pieces is not as important as for open hearth furnaces. In the United States a $100 \%$ shredder charge is economically possible only with continuous melting. The proportion of turnings containing oil must be limited because of smoking and environmental problems. The optimum scrap sizes depend on furnace size.

Special attention must be paid to the non-iron content of the various kinds of scrap. Impurities reduce the value of the scrap, especially nonmetallic impurities that increase the quantity of slag as well as the consumption of energy and, hence, the melting cost. The proportion of iron oxide, the impurities consisting of zinc, tin, and coatings, and the presence of nonmetallic foreign materials may vary widely within the same category of scrap. This variability imposes restrictions on the use of scrap for certain products or processes. Copper and tin in scrap cannot be eliminated in steelmaking and are usually held within manageable limits by dilution. In a steel production process using scrap intensively, the presence of high concentrations of these elements can preclude the use of such scrap as raw material. This is particularly the case in mills that use scrap without any pig iron.

An example of the effect of No. 2 bundle scrap on residual copper and sulfur in the steel is given in Figures 4.2-2 and 4.2-3. These data show that for the example analyzed, there is a direct proportionality between the amount of scrap charged and the levels of copper and sulfur in the steel. ${ }^{(16)}$ Zinc, lead, arsenic, and alkaloid metals, and PVC are also undesirable in recoverable and scrap materials in order to meet product, process or environmental constraints. 


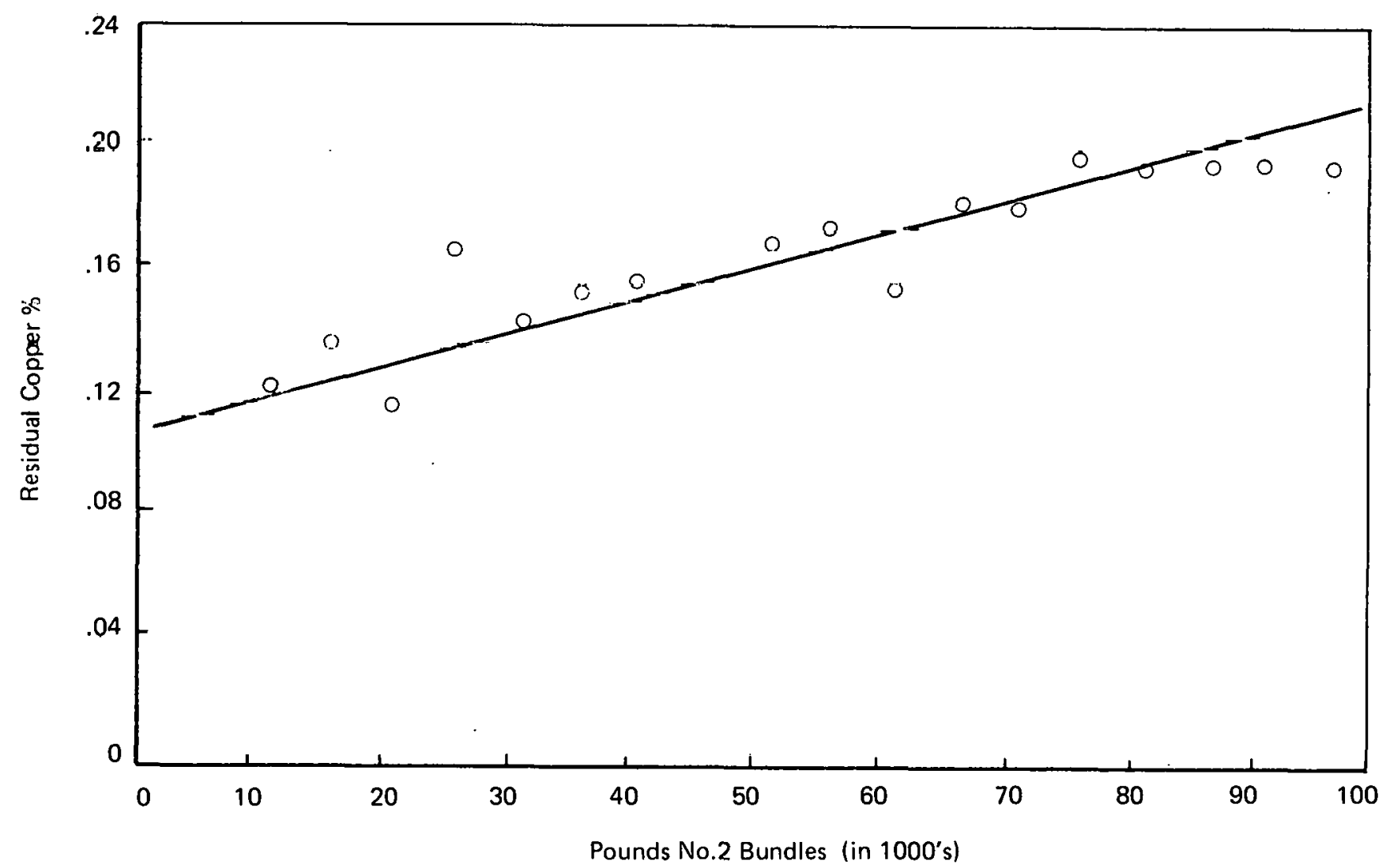

FIGURE 4.2-2 EFFECT OF NO. 2 BUNDLE SCRAP ON RESIDUAL COPPER

Source: Blast Furnace and Steel Plant, "The Operating Economic and Quality Considerations of Scrap Preheating in the Basic 0xygen Process," W.F. Kemner, December 1969. 


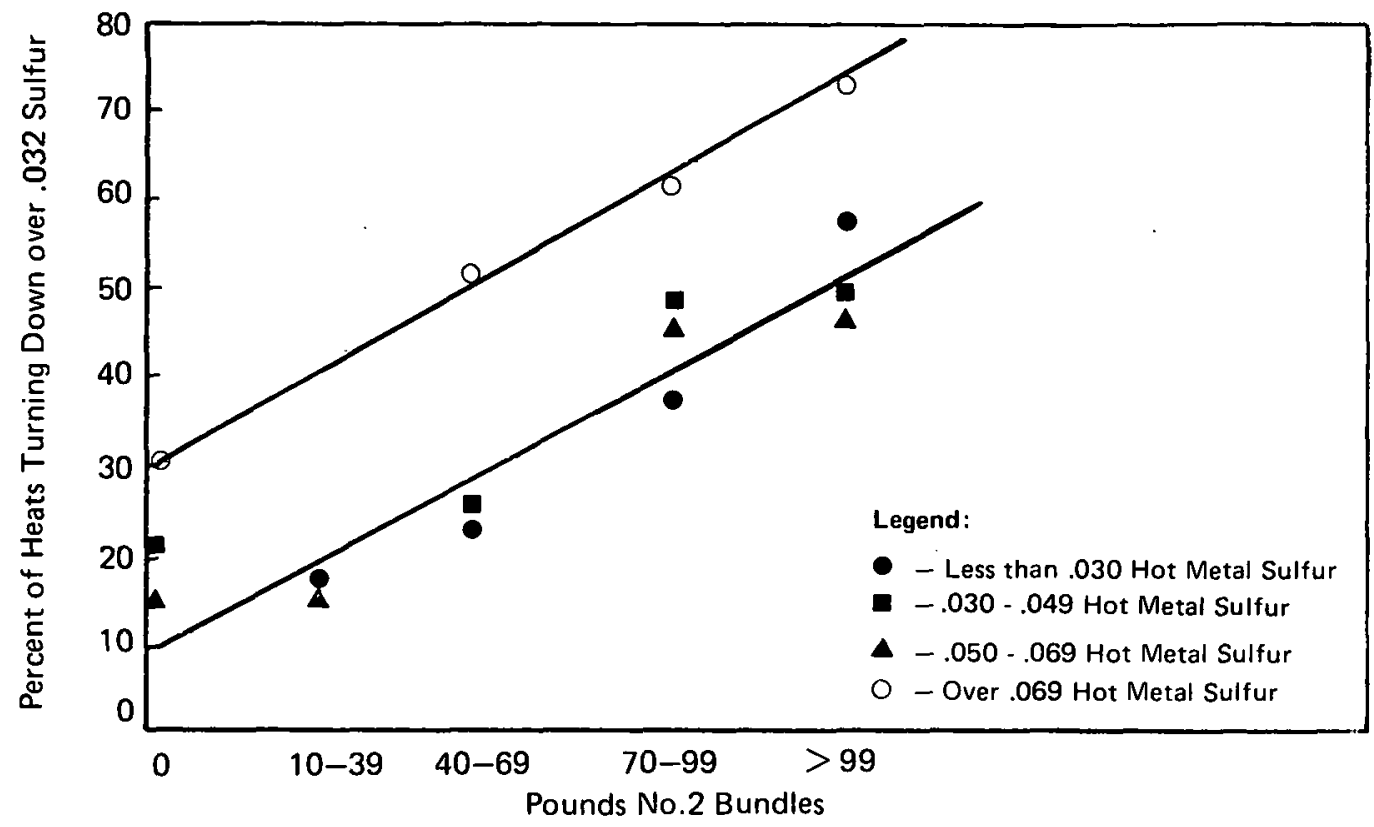

FIGURE 4.2-3 EFFECT OF NO. 2 BUNDLES AND HOT METAL SULFUR ON TURNDOWN SULFUR

Source: Blast Furnace and Steel Plant, "The Operating Economic and Quality Considerations of Scrap Preheating in the Basic 0xygen Process," W.F. Keiinier, December 1969. 
Slag: From a technical point of view the advantages of steel slag recycle are:

- Steel slag serves as a replacement for flux because the lime it contains is in a calcined form. This means a saving in the heat of calcination and hence leads to a small decrease in coke rate.

- Steel slag is a source of iron, manganese and other metals.

The use of sized slag instead of limestone as flux in the production of sinter of about 1.0 basicity has a beneficial effect both on the cold strength of the sinter and on its resistance to degradation during high temperature reduction. ${ }^{(5)}$ The use of this sinter results in lower coke rates.

Quality constraints for recycling steel slags include tramp element content and size distribution. Tramp elements, such as manganese, alloy metal, and phosphorus are transferred to the hot metal in the blast furnace. The type of steel being made determines the allowable limit of these elements in the hot metal

A final factor in steel slag quality is that processed slag for recycle to the blast furnace should not be stockpiled for more than 3-4 weeks. Longer stockpiling results in the hydration of free lime and the disintegration and production of fines. Both factors lead to a loss of effectiveness of the slag as a flux.

\subsection{Ferrous Foundries}

'The recoverable material quality constraints are indirectly related to the process and product constraints. For example, the induction furnace is a melting unit and not a refiner; scrap for the induction furnace must be of good quality and very close to the composition of the finlal product, or suitable for adjustment by alloy addition. In contrast, the electric arc furnace can handle a much more diverse scrap quality because the electric arc furnace is not only a melter, but also a refiner. However, as discussed in the iron and steel section, even with electric arc furnaces, certain elements, like $\mathrm{Cu}$ and $\mathrm{Sn}$, are difficult to remove and the scrap charge must be controlled accordingly.

The cupola is a reducing furnace, and scrap should not contain undesirable impurities which will be entrapped in the cupola metal. Though volatile impurilies like lead and zinc will leave as dust, they can have deleterious effects on refractory life and are undesirable liur environmental reasons. The size of scrap for the cupola is controlled by cupola size.

\subsection{Ferroalloys}

Ferrous scrap used in electric furnace ferroalloy production must be of suitable composition and physical characteristics. The acceptable level of impurities is governed by the specifications for ferroalloys shown in Table 4.2-17.

\subsubsection{Econonic Considerations}

In 1976 the ratio of ferrous scrap consumption to production of raw steel and castings (hot metal equivalent) came to about $50 \%$. Whether this percentage can be raised by 1987 depends on the demand and supply dynamics of the ferrous scrap market. 
On the demand side, the amount of scrap that can be utilized is largely constrained by technical factors. The electric furnace accounted for $19 \%$ of 1976 raw steel production with a charge mix consisting almost entirely of scrap. The basic oxygen furnace (BOF) accounted for $62 \%$ of 1976 raw steel output; the normal scrap charge mix is $28 \%$ with cost penalties associated with deviations from this ratio dependent on plant-specific factors. The open hearth furnace, which accounts for the remaining steel production, is more flexible with regard to the charge mix. The scrap ratio in the charge can be easily changed in response to scrap price. The open hearth furnaces are rapidly being phased out, however, so the proportion of scrap utilized in making raw steel is relatively insensitive to price. In the long run, industry could change capital stock - e.g., opt for electric furnaces - and thereby increase scrap utilization.

Supply consists of "new" scrap generated by current industrial activity and immediately reused, and "old" scrap extracted from discarded steel-containing products. The amount of new scrap generated is a function of technological factors in the steelmaking and steel/consuming industries and is totally price-inelastic in both the short and long run. In principle, scrap price changes will have both a short- and long-run effect on old scrap supply. The amount of old scrap used is a function of price; the short-run effect is that higher scrap prices will-make previously uneconomic scrap sources worthwhile. The long-run effect is that higher scrap prices may induce new scrap processors to come on-stream. In practice, the long-run effect is not important. Scrap processing is usually not a three-shift operation; consequently, excess capacity has always been available.

As we have seen, the percentage of steel that can be profitably produced from scrap, rather than from hot metal, is both a technical and an economic question. However, existing models tend to fall into one of two classes, neither of which adequately addresses both issues. The first class of models are those described as engineering-based, containing highly disaggregated specifications of demand and supply, but completely ignoring the role of price in equilibrating demand and supply. The secund class of models are microeconomic market models in which recognition is given to the role of price. In this latter class of models the specifications of demand and supply functions do not adequately reflect the technological dynamics of the industry.

Arthur D. Little, Inc., has developed an eclectic model of the ferrous scrap market that incorporates both engineering and economic parameters in an attempt to depict realistically the technological and microeconomic factors that characterize the demand and supply dynamics. 'I'he model organizes the extensive technical knowledge concerning this market into a flexible framework that can be used to test the economic viability of a recycling target.

The information incorporated into the model includes details on: the process characteristics of scrap-using and scrap-generating activities; the inventory of obsolete iron and steel scrap; and the price elasticity of obsolete scrap supply.

The purpose of this section is to describe and document the model. The section is organized to cuver: the structure of the ferrous scrap material balance, a review of existing scrap models, and an explanation of the Arthur D. Little model.

\subsubsection{Ferrous Scrap Material Balance}

Developing a consistent material balance for ferrous scrap has proved to be a difficult task. We have relied on the Yearbook of the Institute of Scrap Iron and Steel, Inc. (ISIS) as the basic 
data source. It was necessary to disaggregate the ISIS data to provide the detail that is conceptually appropriate. The disaggregation procedures used will be described later.

Table 4.2-18 contains a ferrous scrap material balance for 1976. Supply (or sources) consists of three major categories: home scrap, prompt industrial scrap, and old (obsolete) scrap. Demand (or uses) includes: steel producers, foundries, other domestic uses, and exports.

Home scrap accounted for about half of the 98 million short tons of U.S. scrap supply in 1976. This excellent quality new scrap is generated by the steel producers and foundries as part of their ongoing processing operations. These generators are also scrap consumers, so the scrap never leaves the plant - hence, the name "home." The volume of home scrap generated is directly related to the level of activity at the steelmaking ared foundry facilities. Design practices also play a role. For example, rolling of widely diversified products will increase the volume of rejects, and conșequently the amount of home scrap.

Prompt industrial scrap accounted for about $21 \%$ of supply in 1976. 'I'his scrap, also of excellent quality and new, is generated by the manufacturing operations in the metalworking industries. Since these industries have no need for scrap, prompt industrial scrap enters the market quickly, typically moving back to U.S. scrap consumers. The volume of prompt industrial scrap generated is a function of steel consumption. Since sleel consumption can diverge from steel production (with the gap largely due to imports) the relative importance of prompt industrial and home scrap can change over timè.

In 1976 , much of the remaining scrap supply was old scrap. This is a highly heterogeneous category, and unlike the new scrap categories of home and prompt industrial, its composition is not well known. The sources of old scrap are the millions of short tons of steel embodied in obsolescent and discarded products. Some sources, such as railroad equipment, represent an easily accessible and known ferrous scrap source. Reclamation rates are very high for these items. On the other hand, junked consumer appliances, because of their marginal value, have low reclamation rates. Scrapped cars represent a source of intermediate economic value. The number of hulks processed is typically a high portion of the cars scrapped, but the relatively low profit margin on car processing continues to make abandoned vehicles in remote regions an unprofitable source of scrap.

On the demand side of the material balance the steel producers clearly dominate. In 1976, $69 \%$ of the U.S. scrap supply was consumed by the steelmaking and pig iron-producing furnaces.

Foundries produce ferrous castings from charges of iron and steel scrap, pig iron, and inoculants. They represent a major source of scrap demand and accounted for $21 \%$ of the 1976 supply. Foundries depend on scrap considerably more than steel manufacturers.

The remainder of the U.S. scrap consumption goes to miscellaneous domestic uses (about $2 \%$ of supply) and exports (about $8 \%$ ). U.S. scrap exports have historically been quite large. Major markets are Japan (particularly for West Coast scrap dealers), Canada, and Mexico, as well as Western Europe, especially Italy and Spain. Almost all the scrap exported is old scrap. 
TABLE $4.2-18$

FERROUS SCRAP MASS BALANCE - 1976

(thousand short ton)

Quantity Demanded

Basic Oxygen Furnace .. 26,207

Electric Furnace $\quad 25,102$

Open Hearth Furnace 12,339

Foundries 20,542

Blast Furnaces $\quad 3,692$

Other 2,035

Total Domestic Demand $\quad \overline{89,916}$

Net Exports $\quad 7,611$

Total Quantity Demanded 97,527

Quantity Supplied

Home Scrap - Steel $\quad 41,984$

Home Scrap - Foundries $\quad 6,561$

Home Scrap - Blast Furnaces $\quad 1,477$

Total Home Scrap $\quad 50,022$

$\begin{array}{ll}\text { Prompt Industrial Scrap } & 20,761\end{array}$

Obsolete Scrap 20,648

$\begin{array}{ll}\text { Total Purchased Sr.rap } & 41,409\end{array}$

Inventory Adjustment $\quad-1,515$

$\begin{array}{lr}\text { Subtotal } & 89,916\end{array}$

Net Exports $\quad 7,611$

$\begin{array}{ll}\text { Total Quantity Supplied } & 97,527\end{array}$

Source: Arthur D. Little, Inc. estimates.

AISI Statistical Report, 1976. 


\subsubsection{Review of Modeling Literature}

Modeling of the ferrous scrap market has been the subject of both doctoral dissertations and consultant reports. Dissertations by Shriner ${ }^{(8)}$ and Plater-Zyberk ${ }^{(7)}$ on the ferrous scrap markets are simple efforts consisting of unconnected regression equations. Because their emphasis tends to be on testing hypotheses rather than on developing a forecasting system, they offer little that is useful in setting ferrous scrap recycling targets.

There are two major consultant reports: a study by the Industrial Economics Research Institute at Fordham University for the American Iron and Steel Institute (AISI) ${ }^{(8)}$; and a study by Robert Nathan Associates for the Metal Scrap Research and Education Foundation..$^{(9)}$ A third interesting, but less substantive, report is by Professor John Elliot of the Department of Metallurgy and Material Sciencc at M.I.T. for the U.S. Rureau of Mines. ${ }^{(10)}$

The Fordham and Elliot studies can be characterized as engineering models. They contain a wealth of detail on the technology of scrap utilization and scrap generation. Their parameters are generally not based on published time series but on knowledge of practices in the steelmaking and steel-using industries; this means that these models cannot be used to replicate history.

The Elliot report contains no mention of scrap price, while the Fordham report concludes that the supply/price elasticity of old scrap is 0.07 , but does not incorporate this parameter into the model. The Fordham price elasticity is based on a regression of monthly quantities against monthly price for the period 1973-1974. During this period, scrap price more than doubled with little effect on the supply, leading to a low estimated elasticity. The small increase in supply was in part due to special short run factors ignored in the regression; for example, during 1974 a shortage of gondola cars limited the shipment of scrap. Also, the number of automobiles scrapped during that period was low - a factor unrelated to scrap price - thus reducing the available scrap pool.

The Nathan report descrihes a standard econometric model. There are equations for demand, supply, and price estimated from quarterly data for the period 1961-1976. The econometric equations contain an unduly large number of independent variables - the average number per equation exceeds six. Undoubtedly, the multicollinearity that this causes raises concern as to the precision of the parameter estimates.

The Nathan equations are highly aggregative and do not realistically capture the technological characteristics of this market. On the demand side, scrap consumption is not disaggregated by furnace type, and on the supply side home scrap is not disaggregated by the generating source.

The Nathan study obtains a value of 0.833 for price elasticity of old supply. This is more than ten times greater than the value obtained by the Fordham study. A major specification problem with the Nathan equation for old scrap leads us to conclude that while the Nathan elasticity is closer to the true value than Fordham's, it is nevertheless too high. The problem is that there is no scrap inventory in the Nathan equation. The inventory of old scrap plays a crucial role in determining the volume that can be supplied. With time, this inventory increases, thereby permitting larger scrap supplies even if real scrap price is unchanged. 


\subsubsection{Data Sources for Arthur D. Little Model}

In order to develop the Arthur D. Little model for this study, it was necessary to have consistent material balance, such as the one presented in Table 4.2-18. It was also necessary to obtain values for the activity variables - e.g., steel production by electric furnace - to derive the model parameters.

The source of data used for ferrous scrap material balance was the Institute of Scrap Iron and Steel, Inc. (ISIS), but the ISIS data was not in the form required for the model. In particular, the problems were:

- Foundry scrap consumption is not reported as such by ISIS; they report scrap consumption by cupolas and electric furnaces.

- There is no series on prompt industrial scrap and obsolete scrap; instead ISIS reports domestically purchased scrap.

- Home scrap is not disaggregated by generating source.

To obtain a data series on foundry scrap consumption, it was assumed that all cupola scrap was consumed by foundries along with a percentage of the electric furnace scrap. This allocation was determined by subtracting the amount of scrap used in steelmaking electric furnaces, as given by AISI, from the total amount of scrap consumed in electric furnaces, as given by ISIS.

To develop a series on prompt industrial scrap and obsolete scrap, a variant of the procedure adopted by Robert Nathan Associates was used. Nathan develops a prompt industrial scrap series by multiplying steel-using activity by a prompt industrial generation factor. The excess of domestically purchased scrap over prompt industrial scrap (with some allowance for losses) was then treated as old scrap supply. The Nathan procedure seriously underestimated the U.S. supply of old scrap, since it ignored the fact that the United States exports a significant amount of scrap - almost all old.

The Arthur D. Little, Inc., prompt industrial scrap series is in essence the one used by Nathan, except that it is based on more recent revised data. In deriving the Arthur D. Little old scrap series, the excess of purchased over prompt industrial scrap was first calculated. Next, exports were added to the result of the preceding operation to give obsolete scrap supply.

Total home scrap, as reported by ISIS, was disaggregated by Arthur D. Little, Inc., into the amount generated by pig iron production, raw steel production, and foundries. Engineering-based parameters were multiplied by activity levels to develop a home scrap series by source. Not surprisingly, adding up the values for these three sources gave a figure that did not agree with the ISIS home scrap total. Consequently, the numbers were "calibrated" to force consistency with the reported datia.

The activity variables required for the Arthur D. Little model consist of data on the production levels in the steel and foundry industry. The source of data for steel variables was the American Iron and Steel Institute (AISI), Annual Statistical Report. For the foundry industry, the source was the U.S. Department of Commerce, Bureau of the Census, Current Industrial Reports: Series M33A. The Arthur D. Little model also required an inventory of old scrap. This was obtained from the Fordham Study which obtained an inventory analysis originally done by Ballelle. ${ }^{(11)}$ 


\subsubsection{Description of Model}

The Arthur D. Little model for ferrous scrap is articulated to determine the percentage of scrap that can be economically recycled in a given year. The model forecasts the ferrous scrap material balance for the year and the price of scrap that will bring about such balance. In the model, a given material balance reflects assumed values for demand and supply parameters; changing the demand parameter values will change the scrap consumption levels and, therefore, the percentage of metal that is recycled. Changed scrap consumption will, of course, mean a new material balance and a new equilibrium scrap price. Thus, the Arthur D. Little model can trace out the scrap price corresponding to a given target. Targets are not always economically rational; consequently, the model has built into it logic statements that test the feasibility of a target.

Figure 4.2-4 contains a schematic exposition of the model logic and Tables 4.2-19 to 4.2-21 document the model. As the figure demonstrates, the model contains a Demand Module, a (New) Scrap Supply Module, and an Integration Module. These mndules, nr hlnrks, are recursively linked. Specifically, demand for scrap and supply of new scrap (home and prompt) is predicted, using known technological relationships. The excess of demand over new scrap supply constitutes the requirement for old scrap. The Integration Module solves for the scrap price necessary to bring forth the required old supply.

The model's recursive structure may be criticized for ignoring the simultaneity of the market. Open hearth furnaces do change their scrap utilization in response to the ratio of scrap price to pig iron price. Also BOF's faced with an extremely low scrap-to-pig price ratio could, in theory, conceivably opt for preheating and so raise their scrap.demand. However, historical data do not indicate any responsiveness of BOF scrap utilization to scrap price. Therefore, from the data, at least, demand appears to be price-inelastic.

\subsubsection{Special Considerations}

Several factors must be considered in analyzing the consumption of recnverahle materials by the ferrous industries. The technical and esonnmic considerations have been discussed in Sections 4.2 .3 and 4.2.4. Some of the other considerations not included in those sections are:

- Steelmaking furnace process mix in 1987

- Variable use of scrap by basic oxygen furnaces

- The trend toward continuous casting

- Scrap substitutes

Because these considerations are of special importance in determining future recycling targets for the ferrous industry, they are discussed in this section.

\subsubsection{Expected Process Mix in 1987}

In 1960, the percentages of total raw steel produced by open hcarth and basic oxygen furnaces were $87.0 \%$ and $3.3 \%$, respectively. By 1976 , these percentages had so drastically changed that basic oxygen furnaces accounted for $62.4 \%$ and open hearths only $18.4 \%$ of raw steel production. In the same period, the percentage of raw steel produced by electric arc furnaces grew from $8.4 \%$ to $19.3 \%{ }^{(12)}$ 


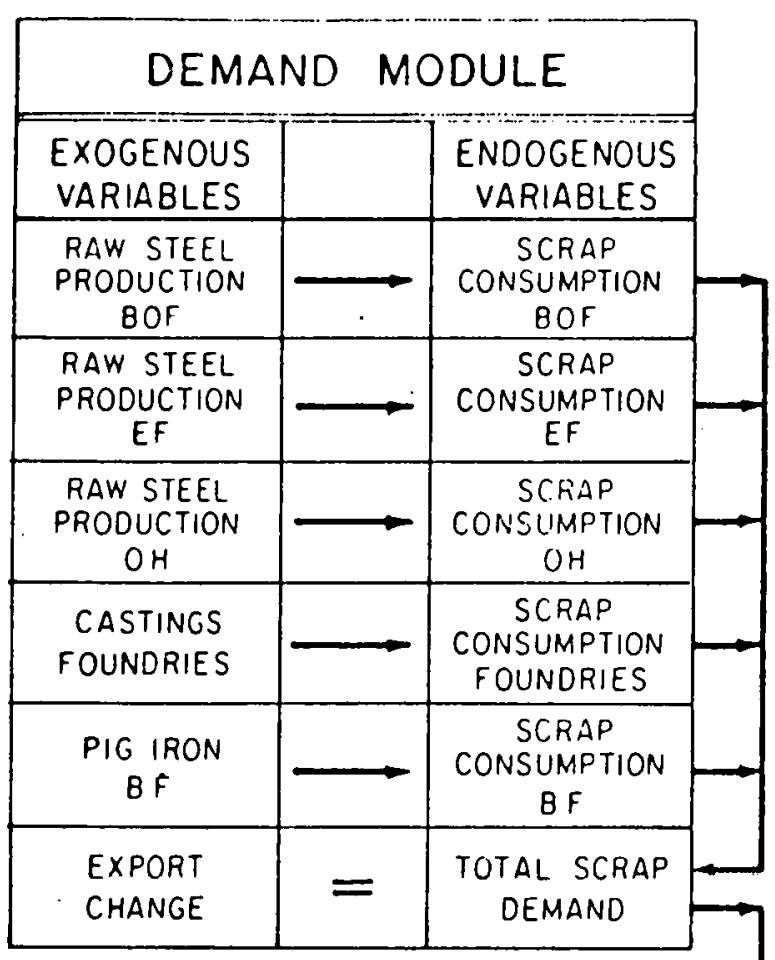

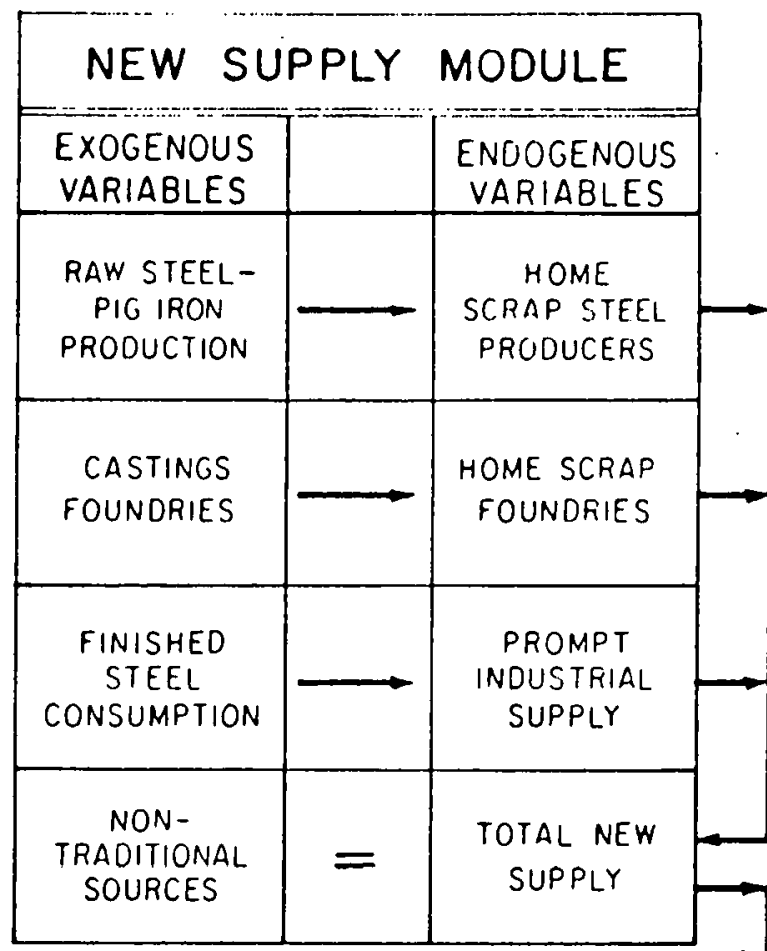

\begin{tabular}{|c|c|c|}
\hline \multicolumn{2}{|c|}{ INTEGRATION } & \multirow{2}{*}{$\frac{\text { MODULE }}{\bar{c}_{\text {ENDOGENOUS }} \text { VARIABLES }}$} \\
\hline $\begin{array}{l}\text { EXOGENOUS } \\
\text { VARIABLES }\end{array}$ & & \\
\hline & & NET DEMAND \\
\hline $\begin{array}{l}\text { STEEL } \\
\text { INVENTORY }\end{array}$ & & $\begin{array}{l}\text { WITHORAWAL } \\
\text { RATE }\end{array}$ \\
\hline $\begin{array}{c}\text { PRICF } \\
\text { ELASTICITY } \\
\text { COEFFICIENT }\end{array}$ & & SCRAP PRICE \\
\hline $\begin{array}{l}\text { PIG IRON } \\
\text { PRICE }\end{array}$ & & $\begin{array}{l}\text { RELATIVE } \\
\text { SCRAP } \\
\text { PRICE }\end{array}$ \\
\hline $\begin{array}{l}\text { HISTORICAL } \\
\text { WITHDRAW } \\
\text { RATE }\end{array}$ & $\geq$ & $\begin{array}{l}\text { FEASIBILITY } \\
\text { CHECKS }\end{array}$ \\
\hline
\end{tabular}

FERROUS SCRAP MODEL SCHEMATIC

FIGURE $4 . \hat{\imath}-4$ 
TABLE $4.2-19$

EQUAT IDNS OF THE FERROUS SCRAP MCDEL

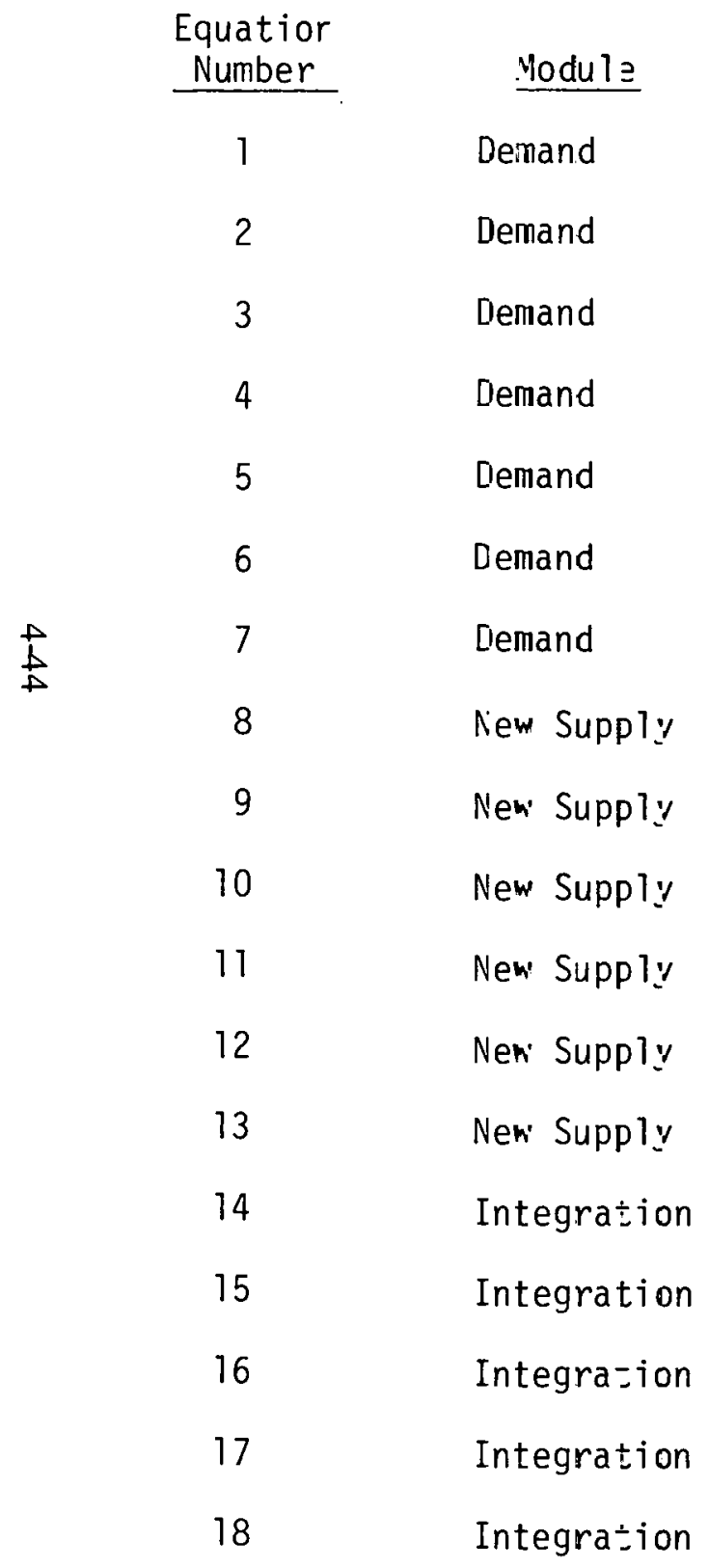

Endogenous Variable

SCBOF

SCEF

$\mathrm{SCOH}$

SCBF

SCFN

SCT

SCD

HSRS

HSBF

HSFN

PIS

TNS

TNPES

NDS

PSC

PRSCF

(NDSiINV)

RPSCF

\section{Explanatory Segment}

d1 * BOFS

d2 * EFS

d3 $\star \quad$ OHS

d4 * BFP

d5 * FNC

$\mathrm{SCBCF}+\mathrm{SCEF}+\mathrm{SCOH}+\mathrm{SCBF}+\mathrm{SCEN}+\mathrm{SCO}$

$S C T+X S: \pm S h$

sl * RS

s2 * BFP

s3 * FNC

s4 * FSC

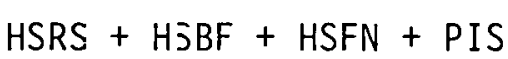

TNS + NIJ

SCD - TNPES

$\mathrm{e} 1+\mathrm{e} 2$ (NDS/INV)

PSC/PPIG

If $\geq 0.015$ Sollution $=$ Nonfeasible

If $\leq 0.41$ or $\geq 0.60$ Solution $=$ Nonfeasible 
DEMAND MODULE

Endogenous Variables

1. SCBOF = Consumption of scrap by basic oxygen furnaces (BOF)

2. $\mathrm{SCBF}=$ Consumption of scrap by blast furnaces (BF)

3. SCEF = Consumption of scrap by electric furnaces (EF)

4. SCFN = Consumption of scrap by foundries

5. SCO = Other scrap consumption

6. $\mathrm{SCOH}=$ Consumption of scrap by open hearth furnaces $(\mathrm{OH})$

7. SCT = Total domestic scrap consumption

Exogenous Variables

1. $\mathrm{BOFS}=$ Raw steel production by BOF

2. $\mathrm{BFP}=\mathrm{BF}$ pig iron production

3. $E F S=$ Raw steel production by $E F$

4. $\mathrm{SCO}=$ Other scrap consumption

5. $X S C=$ Scrap exports

b. $S A$ = Statistical adjustments

7. $S C D=$ Total scrap demand

NEW SUPPLY MODULE

Endogenous Variables

1. HSRS = Home scrap production by steel producers

2. $\mathrm{HSBF}=$ Home scrap production by pig iron producers

3. . HSFN $=$ Home serap production by casting producers 
TABLE $4.2-20$

(Continued)

4. PIS = Prompt industrial scrap supply

5. $\quad$ TNPES $=$ Total non-price elastic scrap supply

6. TNS = Total new scrap supply

Exogenous Variables

1. $F S C=$ Finished steel consumption

2. RS = Raw st.epl pronduction

3. NID - Scrap frum llew technolog1es, e.g., urban wasto

INTLGRATION MODULE

Endogenous Variables

1. NDS = Net requirement for old scrap

2. PSC = Price of scrap

3. RPSCP $=$ Relative scrap to pig price

Exogenous Variables

1. INV = Scrap inventory

2. PPIG = Price of pig 
DEMAND MODULE

1. $d 1=$ BOF scrap charge coefficient

2. $d 2=E F$ scrap charge coefficient

3. $\mathrm{D} 3=\mathrm{OH}$ scrap charge coefficient

4. $d 4=B F$ scrap charge coefficient

5. $d 5=$ Foundry castings production

NEW SUPPLY MODULE

1. $s 1=$ Steel home scrap generation rate

2. $s 2=$ Pig iron home scrap generation rate

3. $s 3$ = Casting home scrap generation rate

4. $s 4=$ Prompt industrial generation rate

INTEGRATION MODULE

1. el = Wilhdráwál cơnislànt

2. $\mathrm{e} 2=$ Withdrawal price slope 
The decline of the open hearth furnace and concurrent increase in basic oxygen and electric arc furnace production can be attributed to several factors. Foremost among these is that the cost of production is higher for open hearths than for competitive processes. In recent years this differential has been exacerbated by the need for pollution control devices. Other factors include the increased productivity of the basic oxygen furnace and the proliferation of small scale "mini mills" that produce raw steel from local sources of ferrous scrap or, in a few cases in the United States, direct reduced iron.

The trend away from open hearth furnaces is expected to continue. Predictions ${ }^{\{13,14\}}$ of the percentage of total raw steel produced by open hearths for 1987 range from $0 \%$ to $10 \%$. Industry observers ${ }^{(14)}$ indicate that by 1987 the primary role for open hearths will be in handling swings in steel demand, with basic oxygen furnaces and electric arc furnaces providing most of the raw steel production.

'I'his prediction of steelmaking process mix is important when estimating recycle targets in that each furnace has distinct scrap utilization requirements. Electric arc furnace installations are generally not located near a ready supply of hot metal and are normally operated with charges consisting primarily of scrap or even $100 \%$ scrap. The basic oxygen furnace is constrained by the thermal balance within the furnace to operate with a maximum scrap charge of ahmut $28-30 \%$. In contrast, open hearth shops are extremely flexible with regard to scrap utilization and can operate with virtually any scrap proportion in the metallic charge.

A change in the process mix of the three steelmaking furnaces could therefore significantly affect overall scrap utilization as a fraction of steelmaking furnace charge. This has not been true, however, for the period 1960-1976, during which the overall scrap ratio has been surprisingly constant, averaging $45.2 \%$ with a standard deviation of $0.6 \%$, despite dramatic shifts in the process mix (Table 4.2-22).

A number of scenarios are presented in Section 4.2.6 in order to quantify the target under different procese mix situations.

\subsubsection{Scrap Use by Basic Oxygen Furnaces}

Basic oxygen furnaces consumed 26.20 million short tons of ferrous scrap and 66.1 million short tons of hot metal in 1976 to produce 79.9 million short tons of raw steel. ${ }^{(12)}$ These statistics indicate that in 1976 metallic charges to basic oxygen furnace shops averaged about $28 \%$ scrap. Historically, scrap as a percentage of the charge to the basic oxygen furnace has varied between 26.9 and $30.6 \%$. The iron and steel industry would like to reduce its dependence on purchased scrap since its supply and prices fluctuate widely.

The basic oxygen process utilizes ferrous scrap (and, to a lesser extent, iron oxides), not only as a source of iron units, but also as a coolant for controlling temperature. Consequently, scrap usage cannot be arbitrarily changed without adjusting other variables to maintain the thermal balance required for the smooth operation that is characteristic of the process.

Theoretically, raising the hot metal temperature by $100^{\circ} \mathrm{F}$ would allow an increase of 67 pounds of scrap per ton of hot metal, or about two percentage points of the charge. Other techniques of increasing scrap usage in the BOF include the addition of external energy sources to 
TABLE $4.2-22$

SCRAP IN FURNACE CHARGE AS A PERCENTAGE OF RAW STEEL PRODUCTION BY FURNACE TYPE (1960-1976): IRON AND STEEL SEGMENT

\begin{tabular}{|c|c|c|c|c|c|c|c|}
\hline & \multicolumn{2}{|c|}{ Basic Oxygen } & \multicolumn{2}{|c|}{ Open Hearth } & \multicolumn{2}{|c|}{ Electric } & $\begin{array}{c}\text { A11 } \begin{array}{l}\text { Steelmaking } \\
\text { Furnaces }\end{array} \\
\text {. }\end{array}$ \\
\hline Year & $\begin{array}{l}\text { Steel } \\
\text { Production }\end{array}$ & $\begin{array}{l}\text { \% Scrap in } \\
\text { Charge }\end{array}$ & $\begin{array}{l}\% \text { Steel } \\
\text { Production }\end{array}$ & $\begin{array}{l}\text { \% Scrap in } \\
\text { Charge }\end{array}$ & $\begin{array}{l}\% \text { Steel } \\
\text { Production }\end{array}$ & $\begin{array}{l}\text { \% Scrap in } \\
\text { Charge }\end{array}$ & \% Scrap in Charge \\
\hline 1976 & 62.4 & 28.4 & 18.4 & 44.1 & 19.2 & 98.4 & 44.7 \\
\hline 1975 & 61.6 & 28.3 & 19.0 & 44.5 & 19.4 & 96.8 & 44.7 \\
\hline 1974 & 56.0 & 28.6 & 24.4 & 45.8 & 19.6 & 97.0 & 46.2 \\
\hline 1973 & 55.2 & 28.7 & 26.4 & 44.5 & 18.4 & 96.9 & 45.4 \\
\hline 1972 & 56.0 & 28.7 & 26.2 & 45.46 & 17.8 & 97.0 & 45.3 \\
\hline 1971 & 53.1 & 28.9 & 29.5 & 43.6 & 17.4 & 97.9 & 45.2 \\
\hline 1970 & 48.1 & 30.0 & 36.5 & 45.0 & 15.4 & 99.0 & 46.0 \\
\hline 1969 & 42.7 & 29.9 & 43.2 & 45.1 & 74.1 & 98.6 & 46.2 \\
\hline 1968 & 37.1 & 29.1 & 50.1 & 44.1 & 12.8 & 97.4 & 45.4 \\
\hline 1967 & 32.7 & 29.4 & 55.7 & 41.6 & 11.6 & $98: 0$ & 44.2 \\
\hline 1966 & 25.3 & 29.0 & 63.4 & 41.5 & 11.0 & 98.4 & 44.4 \\
\hline 1965 & 17.4 & 29.6 & 71.6 & 41.6 & 10.5 & 99.7 & 45.5 \\
\hline 1964 & 12.1 & 30.6 & 77.2 & 41.2 & 9.9 & 97.9 & 45.2 \\
\hline 1963 & 7.8 & 28.0 & 81.3 & 41.0 & 10.0 & 98.0 & 45.3 \\
\hline 1962 & 5.6 & 26.9 & 84.3 & 40.3 & 9.2 & 97.8 & 44.5 \\
\hline 1961 & 4.0 & 27.9 & 86.2 & 40.9 & 8.8 & 97.3 & 45.0 \\
\hline 1960 & 3.3 & 28.7 & 87.0 & 41.7 & 8.4 & 96.4 & 45.3 \\
\hline Source: & AISI Annual & Statistical & Reports, 1960 & 76. & & $\begin{array}{l}\text { Average: } \\
\text { Standard }\end{array}$ & $\begin{array}{l}45 .: 1 \\
\text { Deviation: } 0.59\end{array}$ \\
\hline
\end{tabular}


the charge, such as. silicon, minimizing heat losses of the process, or preheating the scrap. There are practical and economic limitations to implementing these concepts, however. On a limited scale, the Alan Wood basic oxygen furnace operation (now closed down) ${ }^{(18)}$ demonstrated that scrap charge ratios up to about $45 \%$ could be achieved through scrap preheating. The economics of scrap preheating varies with scrap and energy prices as well as with capital costs of retrofitting the preheating system and is very site-specific.

On the other hand, the industry is anxious to reduce its dependence on purchased scrap because of the uncertainties of the scrap market. The concern is so strong that future integrated plants are being designed to be completely independent of the purchased scrap market. This could have an effect of reducing the ratio of purchased scrap to furnace charge in the foreseeable future.

The approach taken in this investigation is that, although it is possible to change basic oxygen furnace scrap demand coefficients, it is not likely that the ratio will change significantly by 1987 . Thus, scrap coefficients have been estimated for 1987 to be identical to current values.

\subsubsection{The Trend Towards Continuous Casting}

The share of domestic steel output continuously cast equalled $11.8 \%$ ( 14.3 million net short tons) in 1977. This output was an increase of $12 \%$ over the 1976 value and almost four times that of $1969 .{ }^{161}$

Since its debut in 1964 , continuous casting technology has steadily grown within the U.S. iron and steel industry; 46 companies currently operate approximately 84 casters at 64 different locations. The total number of strands is close to 320 with billet casters representing about $70 \%$ of the facilities, followed by slab casters at approximately $27 \%$, and bloom units at $2 \% .^{201}$

Energy, yield, and productivity gains and its compatibility with electric arc furnace operations have made continuous casting an attractive alternatıve to conventional ingot càsting within the iron and steel industry. The improvement in yield associated with continuous casting is pertinent to this study. Elliott ${ }^{(10)}$ has estimated the average yield, defined as short tons of finished steel per ton of raw steel, to be 0.79 for continuous casting compared with 0.69 for conventional casting. Hogan and Koelble ${ }^{(8)}$ have estimated these yields to be 0.78 and 0.70 , respectively.

The improvement in yield is due primarily to a reduction of ingot cropping and subsequent hot-rolling losses. Several steps in the conventional route are eliminated by continuous casting, namely, teeming the molten steel into ingot molds, stripping the molds from the ingots, placing the ingots in the coaking pite to develop an even temperature, and primary rolling hy which the ingots are transformed into intermediate steel shapes. Increased yield necessarily means decreased home scrap generation rates per ton of steel produced.

Predictions of the percentage of total raw steel to be produced by continuous casting in 1987 range from about $20 \%$ to $30 \%$. In the target analysis presented in Section $4.2 .6,25 \%$ continuous casting is used in all scenarios. 


\subsubsection{Scrap Substitutes}

Iron oxides (ore, mill scale, etc.) and directly reduced iron can be partially substituted for ferrous scrap in steelmaking furnaces, although this is presently not common practice in the domestic industry. The potential does exist, however, for substantial quantities of ferrous scrap to be displaced by these substitutes, particularly direct reduced iron, in the future.

It is possible to substitute iron oxides for scrap as a coolant in the basic oxygen furnace. According to published reports, about 0.35 short tons of iron ore can be substituted for each ton of scrap. ${ }^{(10)}$ Although such substitution is not common practice in the United States, it is used extensively elsewhere in the world where hot metal may be plentiful and scrap is limited or scarce and therefore expensive. Unless the ferrous scrap supply in this country should become exceedingly tight, iron oxide substitution will probably not be practiced to any appreciable extent by 1987.

Direct reduced iron offers a much greater potential than oxides as a scrap substitute. New iron oxides (oxide pellets, lump ore, etc.) can be partially reduced in the solid state by reaction with a reductant at a temperature of about $1800^{\circ} \mathrm{F}$. These reduced materials, known as direct reduced iron, can contain up to $95 \%$ of their iron content in the metallic state. They can partially or completely replace ferrous scrap in the steelmaking electric arc furnace. They can also be charged to the blast furnace to increase its productivity or be used in the steelmaking furnace in lieu of scrap and as a cooling agent. ${ }^{(17)}$

Despite the fact that many firms will design, engineer, and construct direct reduction plants and that interest in making steel by this route will be maintained, total production of direct reduced iron in the United States is not expected to exceed a few million short tons by $1987 .{ }^{(16)}$ The recycling target analysis in Section 4.2.6 includes the consumption of 2 million short tons prereduced iron in 1987. This figure is based on published literature(1/) and Arthur D. Little, Inc. estimates.

\subsubsection{Target Estimation}

\subsubsection{Introduction}

The objective of this section is to present the 1987 recycling targets for the ferrous industries (iron and steel, ferrous foundries, and others including ferroalloys). Recycling targets have been computed for a number of probable "scenarios." The scenarios were based on analyses of historical data, discussions with various industry contacts, and Arthur D. Little, Inc. estimates. The econometric model discussed in Section 4.2.4 was used to determine whether or not a given scenario resulted in an acceptable target in the context of scrap availability and the economic viability. The seven scenarios presented in this section fulfilled these conditions.

\subsubsection{Scenarios Analyzed}

Supply and demand coefficients and other assumptions for 1987 used in each of the seven scenarios are presented in Table 4.2-23. The supply and demand coefficients for 1975 and 1976 are 
TABLE $4.2-23$

LIS- OF MODEL PARAMETERS AND ASSUMPTIONS

OOR THE SEVEN SCENARIOS ANALYZEO

FERROUS INDUSTRY

Parameter

A. Supply and Demand Coefficients

Basic Oxygen Furnace scrap charye coeffici झlt

Electric Arc Furnace scrap charge coeffici int

Open Hearth Zurnace scrap charge coefficient

Blast Furnace scrap charge coefficient

Foundry scras charge coefficient

Steel home s:rap 'jeneratior rat?

Pig iron home scrap generat on rate

Casting home scrap ceneration rate

Prompt industrial generatic rate

Price elastizity

B. Industry Activities

Total raw steel production

Basic 0xygen Furnace raw steel production

Electric Arc Furnace raw steel production

Open Hearth =urnace raw steel production

Blast Furnace production

Foundry casting shipment

Finished steal consumption

Inventory of obsolete scrap.

C. Assumptions

Finished steal production/Growth rate

Finished steal consumption/6rowth rate

Steelmaking furnace mix

Basic Oxyzen

Open Hearth

Electric Arc

Raw steel by continuous casing
Unit;

ton/tor raw steel

ton/ton raw stee

ton/to r raw steel

ton/ton hat metal

ton/tor casting sipments

ton/tor raw steel

ton/tor hat metal

ton/tor casting siipments

ton/ton finished iteel consumed

thousand ret tons

thousa nd ret tons

thousand eet tons

thousand ret ton

thousand ret tons

thousand ret ton

thousand ret tons

million $t=-n s$

percent $p \equiv r$ annum

percent $p \equiv r$ annum

percent

percent

percent

percent $\underline{1975}$

0.326

1.015

0.532

0.049

1.230

0.332

0.017

0.396

0.203

0.64

116,640

71,804

22,675

22,162

79,923

15,109

89,016

2,356

\section{6}
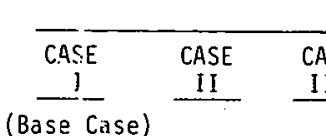

$1.020 \quad 1.030$

0.5260 .1528

$0.042 \quad 0.1741$

$1.226 \quad 1.231$

$0.328 \quad 0.301$

$0.017 \quad 0.02 ?$

$0.392 \quad 0.371$

$0.205 \quad 0.205$

$0.64 \quad 0.64$

$128,000 \quad 173,820$

$\begin{array}{lllll}79,923 & 117,834 & 111,401 & 122,804\end{array}$

$24,614 \quad 47,296 \quad 75,037 \quad 42,325$

$23,475 \quad 3,691 \quad 17,328$

$36,870 \quad 104,730 \quad 104,670 \quad 108,600$

$16,750 \quad 21,980$

$101,078 \quad 1<2,470$

$2,445 \quad 2,826$

19.00

19.44

62.44
19.23

19.23
18.33

10.5

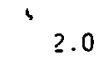

2.0

67.8
5.0
27.2

27.2
25.0

CASE CASE CASE CASE

CASE CASE CASE CASE

……

* Same as the Base Case.

Sources: AISI Annual Statist cal Reports, $3 \Xi$ Metal Producing, vorld Steel Industry Data Handbook, Vol. 1, Arthur D. Little: Inc. estimates. 
also presented for comparison. Some of the key factors in the ferrous industry, which will affect the 1987 recycling target and which have many uncertainties built into them, are:

- The percentage of continuous cast steel

- Foundry scrap charge coefficient

- Total raw steel production

- Mix of steelmaking furnaces

The variations in the key factors are presented in seven scenarios. Case I, the base case, is considered the most likely. The other cases are considered plausible. Cases II, III and V are based on variations in the mix of steelmaking furnaces. Cases IV and VI presume a higher foundry scrap charge coefficient. Case VII projects a lower overall annual growth rate for the iron and steel sector. In order to minimize the number of scenarios, the percentage of continuous cast steel has been fixed at $25 \%$ of total steel production for all cases.

\subsubsection{Basis of Coefficients Used in the Analysis}

The basis of the coefficients for 1987 are:

Raw Steel Production Growth Rate: An analysis of the historical data indicates that the growth rate of raw steel production has been sporadic and has ranged between 1.5 and $2.5 \%$. Discussions with individuals in the industry indicated that the expected growth rate is anticipated to be in the $1.5-2.0 \%$ range. All but one scenario has taken the growth rate as $2 \%$.

Finished Steel Consumption: Consumption of finished steel was assumed to increase at an average annual growth rate of about $2 \%$ until 1987. This figure is based on Arthur D. Little's input/output model of the U.S. economy. The Department of Commerce projects a growth of about $2.2 \%$. Historically, finished steel consumption has averaged approximately $2.5 \%$ annually.

Steelmaking Process Mix: The percentages of raw steel produced by basic oxygen, electric arc, and open hearth furnaces in 1987 were determined as follows:

(1) The growth in raw steel production was split between the basic oxygen furnace and the electric arc furnace, either on a 1:1 basie or $\mathbf{a} 2: 1$ basic. $\Lambda$ n analysis indicated that a 2:1 split would be unlikely because it would impose serious pressures on scrap prices and supply. A 1:1 split was selected for the base case.

(2) Raw steel produced by open hearth furnaces was calculated by assuming that $5 \%$ or $10 \%$ of total raw steel would be produced by open hearths in 1987 . Numerous references cite the proportion of raw steel from open hearths in the mid-eighties to he $5-10 \%$. A $5 \%$ figure was assumed for the base case.

(3) The decrease in open hearth production after 1976 was apportioned between basic oxygen and electric arc furnaces on the basis of hot metal displaced 'l'he increase in basic oxygen furnace production caused by the open hearth decline was estimated by dividing the displaced hot metal quantity by the 1987 basic oxygen furnace scrap demand coefficient.

(4) Total basic oxygen production in 1987 was determined by adding Step 1 and Step 3 values to the 1976 hasic oxygen furnace production figures on the historical trend line. 
(5) Total electric arc production in 1987 was found by subtracting basic oxygen and open hearth furnace production from total raw steel production. This result was checked against projections by industry contacts, Arthur D. Little, Inc., estimates and the Bureau of Mines estimates.

(6) The mix of steelmaking processes was determined by dividing the production rates for each of the steelmaking furnaces by total raw steel production.

Foundry Casting Shipments: The quantity of castings shipped in 1987 was based on Arthur D. Little, Inc. estimates.

Blast Furnace Production: The production of pig iron by blast furnaces in 1987 was calculated by multiplying the pig iron demand coefficients for the steelmaking furnaces and ferrous foundries by their respective production rates. The individual process demands for pig iron were summed to give total pig iron production in 1987. Thus, it is implicitly assumed that pig iron inventories in 1987 are constant.

Inventory of Obsolete Scrap: Hogan ${ }^{(8)}$ has presented the inventory data through 1982 . These data were extended to 1987 by extrapolation and adjustment to incorporate production/consumption of scrap and steel through 1987.

Steelmaking Scrap Demand Coefficient: An analysis of the historical scrap demand coefficients (1959-1976) for the basic oxygen, open hearth, and electric arc furnaces indicated that for each of these furnaces these coefficients have remained reasonably constant during recent years. This is expected to remain constant in the near future. Scrap demand coefficients for the years 1972-1976 were averaged to give the 1987 values. The target analysis is based, therefore, on the growth of the electric arc furnace versus BOF rather than any changes on the Scrap Demand Coefficients of the steelmaking furnaces.

Blast Furnace Scrap Demand Coefficient: Historical blast furnace scrap demand coetficients (1955-1976) were analyzed to develop the trend line forecast to 1987 . The 1987 scrap demand coefficient was estimated to be 0.040 short tons scrap/ton pig iron produced based on the trend data.

Foundry Scrap Demand Coefficient: Historical foundry scrap demand coefficients (19561976) were analyzed. During this period use of pig iron significantly decreased. Industry sources had conflicting views of whether this trend would continue. In view of this uncertainty, two values for the foundry scrap demand coefficient (short tons scrap/ton casting shipment) were used in the estimation of the recycle target: 1.23 (Case I) and 1.30 (Case IV). Although these figures seem low, they are based on the best available published data.

S'teel I'lant Home S'crap Gieneration Factor: 'I'he historical data were analyzed and adjusted to incorporate the change expected with the increase in continuous casting to about $25 \%$ in 1987.

Foundry Home Scrap Generation Factor: This was based on historical trend data. Although the documented figures seem low, the data were used because they are the best documented. Furthermore, any error in the figure does not affect the purchased scrap and obsolete scrap recycling targets significantly.

Blast Furnace Home Scrap Factor: The 1987 figure was based on the historical trend line. The 1987 value was predicted to be 0.022 short tons scrap/ton pig iron produced. 
Prompt Industrial. Scrap Generation Factor: This coefficient was assumed to remain unchanged from 1976 to 1987 . Because of the nature of the scrap generating operations of the manufacturing industries, this factor is expected to change very little, if at all.

\subsubsection{Recycling Targets for 1987}

The recycling targets for each of the seven scenarios analyzed are presented in various formats. Each format represents the ratio of a specific class of ferrous scrap to a specific charge or product. Numerators in the target ratios are:

- Total scrap consumption - home, prompt industrial, and obsolete scrap consumed in the steel industry, ferrous foundries and ferroalloy plants. Slag scrap is included in total scrap

- Purchased scrap consumption - prompt industrial and obsolete scrap consumed in the steel industry, ferrous foundries, and ferroalloy plants

- Obsolete scrap consumed in the steel industry, ferrous foundries and ferroalloy plants

Denominators in the target ratios are:

- Pig iron and scrap charged to steelmaking furnaces, ferrous foundries and ferroalloy plants

- Raw metal equivalent (raw steel plus hot metal equivalent in ferrous foundries)

- Shipments (finished steel plus ferrous castings shipped)

Target ratios have also been calculated for the years 1975 and 1976 in order to validate the model. The analysis for 1975 and 1976 proved the validity of the model. Table 4.2-24 shows the targets for each of the seven scenarios. This table shows that for the base case, purchased scrap target as a percent of scrap and pig iron charged in the ferrous industry increases from $22.6 \%$ in 1976 to $26.4 \%$ by 1987. Similarly, purchased scrap target as a percent of finished product increases from $37.6 \%$ to $41.3 \%$. The rise in recycling targets is due primarily to an expected increase in demand for ferrous scrap by steelmaking electric arc furnaces.

Because iron and steel is the most relevent with respect to recycling of the three sectors (iron and steel, ferrous foundries and ferroalloys) recycle targets specific to this sector are given separately in Táble $4.2-25$.

Table 4.2-26 shows the target in units selected by DOE for recovered materials as a percent of total shipments.

\subsubsection{Sensitivity of Targets to Key Factors}

The recycling targets presented in the previous section are directly affected by a number of factors. The most significant factors are:

- Predicted annual growth rates for the iron and steel and ferrous foundry sectors

- Steelmaking process mix

- Scrap demand coefficients for the three steelmaking furnaces and ferrous foundries

- Raw steel to finished product yields for the iron and steel and ferrous foundry sectors 
TABLE $4.2-24$

RECYCLING RATIOS FOR FERROUS INDUSTRY FOR SEVEN SCENARIOS - 1987

\section{$\underline{\text { Scenario }}$}

$1975=$
$1976=$
$1987=$

Case I: Base case

C.ase II: Base case except

- Production by open hearth furnaces equals $10 \%$ total raw steel production.

Case III: Base case except

- Growth in raw steel production split $2: 1$ between basic oxygen and electric arc shops.

Case IV: Base case except

- Scrap demand coefficient for foundries equals 1.3 ton/ton shipments.

Case V: Base case except

- Growth in raw steel production splil 2:1 between basic oxygen and electric arc shops.

- Production by open hearth furnaces equals $10 \%$ total

raw steel production.

Case VI: Base case except

- Growth in raw stcel production split 2:1 between basic oxygen and electric arc shops.

- Scrap demand coefficient for foundries equals 1.3 ton/ton shipments.

Case VII: Base case except

- Growth rate for finished steel production equals $1.6 \%$ per annum.

\section{Target Expressed As Ratio of:}

\begin{tabular}{|c|c|c|c|c|c|c|c|c|}
\hline $\begin{array}{l}\text { Total } \\
\text { Scrap } \\
\text { Consumed }\end{array}$ & $\begin{array}{l}\text { Purchased } \\
\text { Scrap } \\
\text { Consumed }\end{array}$ & $\begin{array}{l}\text { Obsolete } \\
\text { Scrap } \\
\text { ronsulmen }\end{array}$ & $\begin{array}{l}\text { Total } \\
\text { Scrap } \\
\text { r.nnsiumer }\end{array}$ & $\begin{array}{l}\text { Purchased } \\
\text { Scrap } \\
\text { rinnsumer }\end{array}$ & $\begin{array}{l}\text { Obsolete } \\
\text { Scrap } \\
\text { Cnnsumed }\end{array}$ & $\begin{array}{l}\text { Total } \\
\text { Scrap } \\
\text { Consumed } 1\end{array}$ & $\begin{array}{l}\text { Purchased } \\
\text { Scrap } \\
\text { Consumed }\end{array}$ & \\
\hline
\end{tabular}

to

Pig Iron and Scrap Charged ${ }^{3} \quad$ Raw Metal Equivalent ${ }^{4}$

to

$\begin{array}{lll}0.507 & 0.224 & 0.115 \\ 0.508 & 0.226 & 0117\end{array}$

U.byi

U. 261

U. 134

ก. 588

0.261

0.135

0.597

0.294

0.153

0.297

0.156

0.839

0.413

0.214

0.538

0.266

0.139

0.600

0.843

0.418

0.219

0.520

0.249

0.122

0.581

0.278

0.136

0.816

0.390

0.191

0.539

0.269

0.143

0.605

0.302

0.160

0.849

0.424

0.225

0.522

0.251

0.124

0.584

0.281

0.139

0.820

0.394

0.195

0.524

0.254

0.128

0.588

0.285

0.144

0.826

0.400

ง. 2Uะ

0.533

0.261

0.135

0.593

0.291

0.150

0.834

0.409

0.211

1. Includes home, prompt industrial and obsolete scrap.

2. Includes prompt industrial and obsolete scrap.

3. Charged to steelmaking furnaces, ferrous foundries and ferroalloy plants.

4. Raw steel plus hot metal equivalent in the ferrous foundries.

5. Finished steel plus ferrous casting shipments.

SOURCE: Arthur D. Little, Inc. 
TABLE 4.2-25

RECYCLING RATIOS FOR THE IRON \& STEEL SEGMENT FOR SEVEN SCENARIOS - 1987

Scenario

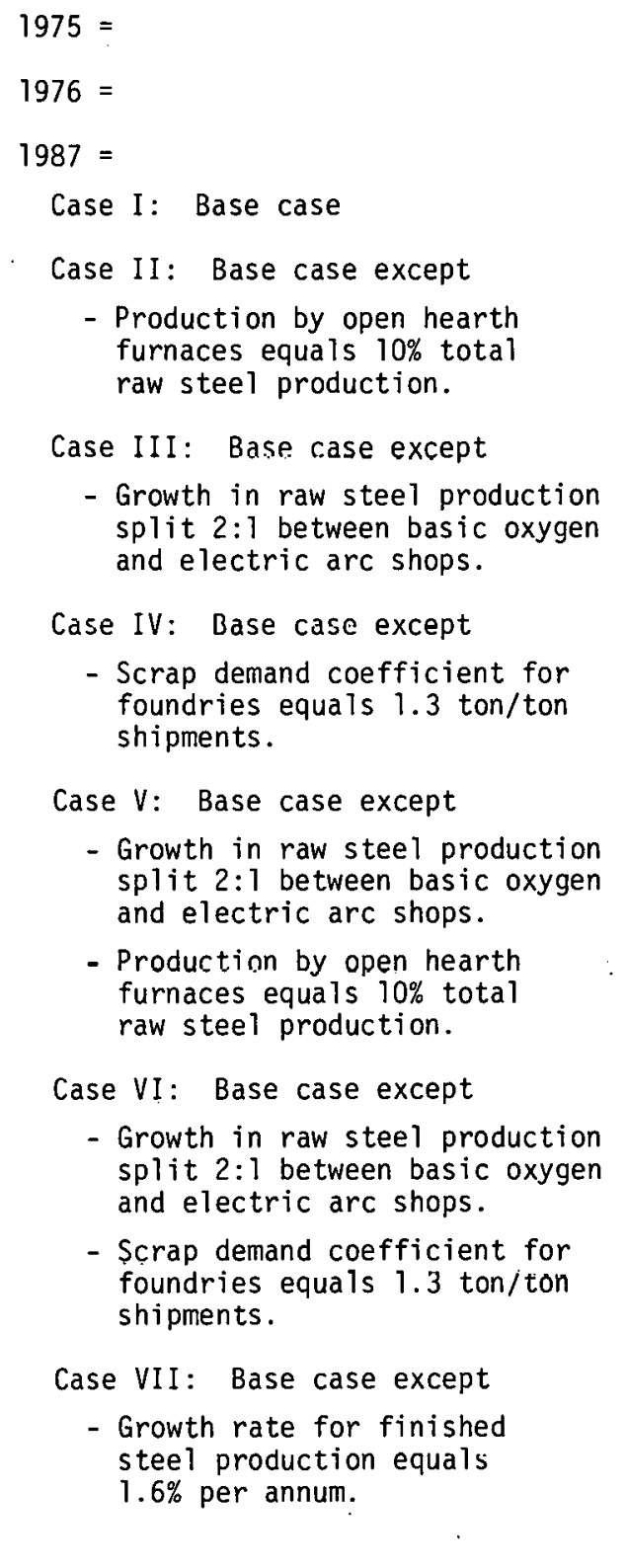

Target Expressed As Ratio of:

\begin{tabular}{|c|c|c|c|c|c|}
\hline $\begin{array}{l}\text { Total } \\
\text { Scrap } \\
\text { Consumed } 2\end{array}$ & $\begin{array}{l}\text { Purchased } \\
\text { Scrap } \\
\text { Consumed }\end{array}$ & $\begin{array}{l}\text { Total } \\
\text { Scrap } \\
\text { Consumed }\end{array}$ & $\begin{array}{l}\text { Purchased } \\
\text { Scrap } \\
\text { Consumed }\end{array}$ & $\begin{array}{l}\text { Total } \\
\text { Scrap } \\
\text { Consumed }\end{array}$ & $\begin{array}{l}\text { Purchased } \\
\text { Scrap } \\
\text { Consumed }\end{array}$ \\
\hline
\end{tabular}

\section{Pig Iron and Scrap Charged 4}
0.447
0.158
0.446
0.158

0.490

0.213

0.492

0.216

0.472

0.195

0.534

0.227

0.742

0.307

0.490

0.213

0.553

0.241

0.768

0.334

0.473

0.195

0.538

0.224

0.747

0.312
0.195

0.484

0.207

0.547

0.234

0.760

0.325

1. Inçudes ferroalloy segment.

2. Includes home, prompt industrial and obsolete scrap.

3. Includes prompt industrial and obsolete scrap.

4. Charged to steelmaking furnaces and ferroalloy plants.

5. Raw steel.

6. Finished steel.

Source: Arthur Ũ. LIttle, IIIL. 
TABLE $4.2-26$

\title{
RECOVERED MATERIAL TARGET FOR FERROUS INDUSTRY (1987)
}

\author{
Recovered Materia]*
}

\section{* Prompt industrial and obsolete scrap. \\ ** St.epl and foundry shipments.}

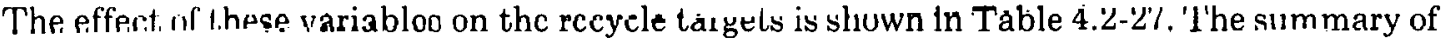
the results is as follows:

- Increasing the growth rate of finished steel production by $20 \%$ increases the purchased scrap target by $1.1 \%$ on a metallic charge basis and $1.2 \%$ on a finished product basis. Det:reasing the growth rate by $10 \%$ lowers the targets by $1.1 \%$ and $0.9 \%$, respectively.

- Increasing the estimate of foundry shipments by $10 \%$ increases the purchased scrap target by $1.9 \%$ on a metallic charge basis and $1.7 \%$ on a finished product basis. Decreasing foundry shipments by $10 \%$ lowers the targets by $1.5 \%$ and $1.7 \%$, respectively.

- Increasing the ratio of electric arc to basic oxygen furnace growth rate from 1:1 to $1: 2$ decreases the purchased scrap larget by $5.7 \%$ on a metallic charge basis and $5.6 \%$ on a finished product basis.

- Increasing the percentage of total raw steel produced by open hearth furnaces from $5 \%$ to $10 \%$ increases the purchased scrap target by $0.7 \%$ on a metallic charge basis and $1.2 \%$ on a finished product basis.

- Increasing the basic oxygen furnace scrap demand coefficient by $10 \%$ increases the purchased scrap target by $6.4 \%$ on a metallic charge basis and $6.3 \%$ on a finished product basis. Decreasing this coefficient by $10 \%$ lowers the targets by $6.1 \%$ and $6.3 \%$, respectively.

- Increasing the open hearth furnace scrap demand coefficient by $10 \%$ increases the purchased scrap target by $2.7 \%$ on a metallic charge busis and $2.4 \%$ on a tinished product basis. Desreasing this coefficient by $10 \%$ lowers lhy largets by $2.3 \%$ and $2.2 \%$, respectively.

- Increasing the scrap demand coefficient for electric arc furnaces to the maximum possible (1.05) increases the purchased scrap target by $1.1 \%$ on a metallic charge basis and $1.7 \%$ on a finished product basis. Mecreasing this coefficicnt by $10 \%$ lowers the targets by $5.7 \%$ and $7.7 \%$, respectively.

- Increasing the scrap demand coefficient for the ferrous foundries by $6 \%$ increases the purchased scrap target by $1.9 \%$ on a metallic charge basis and $2.7 \%$ on a finished product basis. 
TABLE $4.2-27$

SENSITIVITY OF TARGETS TO KEY FACTORS

FERROUS INDUSTRY

Factor

1976

1987

Base Case

Finished Steel Production Growth Rate rises $20 \%$ falls $20 \%$

Foundry Shipments

rises $10 \%$

falls $10 \%$

Electric Arc: Basic Oxygen Growth Rate

$1: ?$ (base case)
$1: 2$

Percent of Raw Steel from Open Hearth Furnace $5 \%$ (base case)

$10 \%$

Scrap Demand Coefficient: Basic Oxygen Furnace

rises $10 \%(.359)$

falls $10 \%(.259)$

Scrap Demand Coefficient: Open Hearth Furnace

rises $10 \%(.64)$

falls $10 \%(.52)$

Scrap Demand Coefficient: Electric Arc Furnace

rises to maximum (1.05)

falls $10 \%(.93)$

Scrap Demand Coefficient: Ferrous Foundries

base case (1.23)

rises $6 \%(1.30)$

Yield: Iron and Steel

rises $10 \%(.79)$

falls $10 \%(.65)$

Yield: Ferrous Foundries

rises $10 \%(.74)$

falls $10 \%(.61)$
Target Expressed as Ratio of Total Purchased Scrap to

Metallics

Charged

.226

Raw Steel

Equivalent

Finished

.261

.376

.264

.294

.413

.267

.261

.298

.291

418

.409

.269

.260

299

.290

420

.406

.264

.249

294

.278

413

.390

.264

.266

.294

.297

.413

.418

.281

.248

.313

.276

.439

.271

.258

.301

.287

.423

.404

.267

.249

.299

.420

.271

.381

.264

.269

.294

.302

.413

.310

.346

449

.264

.294

.297
.407

.424 
- Increasing the yield (finished steel/raw steel) for the iron and steel sector by $10 \%$ increases the purchased scrap target by $17.4 \%$ on a metallic charge basis and $8.7 \%$ on a finished product basis. Decreasing the yield by $10 \%$ lowers the targets by $17.1 \%$ and $9.7 \%$, respectively.

- Increasing the yield (finished casting/raw steel) for the ferrous foundry sector by $10 \%$ has little effect $(<0.5 \%)$ on the purchased scrap target on a metallic charge basis and lowers the target by $1.4 \%$ on a finished product basis. Decreasing the yield by $10 \%$ increases the targets by $1.1 \%$ and $2.7 \%$, respectively.

Indirectly, the recycling target is affected by such factors as the availability of scrap substitutes (e.g. prereduced iron), scrap exports, and the inventory of obsolete scrap.

The availability of scrap substitutes from domestic or imported sources could affect the scrap market and, therefore, the target. However, because the tonnage of scrap substitutes involved is expected to be low, the target is not very sensitive to changes in the availability of the scrap substitutes. In the base case scenario (Case I) it is assumed that 2 million short tons of prereduced iron will be available in 1987.

Scrap exports are a major factor in the recycling target. Because scrap exports impact the domestic scrap supply and prices, they can, in the long run, alter the process mix in the iron and steel industry and the scrap demand coefficients for the steelmaking processes and ferrous foundries. These factors, in turn, can affect the targets. However, the impact of scrap exports on such factors as the process mix, industry structure, etc., is outside the scope of this study.

Changes in the size of obsolete scrap inventory affect scrap supply, and therefore scrap prices. In turn these affect the long-term trends in process mix, furnace scrap demand coefficients, etc. - thereby affecting the recycling targets. Detailed study of the impact of obsolete scrap inventory changes on the recycling targets is outside the scope of this study.

\subsection{ALUMINUM}

\subsubsection{Selection of Recoverable Materials}

The recoverable materials considered for inclusion in the aluminum industry. can be grouped into three broad categories:

- Purchased New Scrap

- Purchased Old Scrap

- Non-Bauxite Sources of Alumina

The various materials considered for inclusion under these three categories are presented in Table 4.3-1. Each "recoverable material" was assessed using the selection criteria discussed in Section 4.1 , to determine whether it would be considered in this analysis.

New scrap includes material generated in the production of primary aluminum, the fabrication of aluminum mill products, or the manufacture of finished aluminum products. It includes aluminum in the form of solids such as new casting scrap; clippings or cuttings of new sheet, rod, wire, and cable; borings and turnings from the machining of aluminum parts; residues, drosses, sweepings, etc.; and aluminum foil. New scrap in any of the above forms can be further 


\section{SELECTION OF RECOVERABLE MATERIALS}

\section{ALUMINUM INUDSTPY}

Does the Recoverable Material

Meet Criteria* for Inclusion?

Recovered Material

Yes

No

NEW! SCRAP

Purchased New Scrap

Solids and Clippings $X$

Borings and Turnings $x$

Residue (Drosses and Skimmings) $X$

Foil and Others $X$

Runaround or Home Scrap $X$

OLD SCRAP

Purchased 01d Scrap

Castings, Sheet, and Clippings. $X$

Aluminum Cans $x$

Sweated Pig $X$

Copper-Aluminum Radiators and others

$x$

$x$

Aluminum Fraction of Municipal

Solid Hastes (MSW)

$X$

Aluminum Fraction of Shredded

Automobiles

$$
x
$$

$x$

ALUMINA FROM NON-BAUXITE SOURCES

Coal Mining Wastes

Residue from 0 il Shale Operations

${ }^{\star}$ Criteria for Inclusion outlined in Section 4.1 . 
categorized as being purchased or runaround scrap. Purchased new scrap (or prompt industrial scrap) is scrap purchased, imported, or treated on toll by primary or secondary smelters; all purchased new scrap is considered in this analysis. Runaround (or home scrap), is new scrap recovered or recycled within the facility generating the scrap. Such scrap, by definition, never leaves the company generating it and therefore is never marketed as scrap. Home scrap complies with the criterion for the selection of recoverable materials, but no data on home scrap are available, and hence it has not been included in the estimation of targets.

Old scrap, all of which is purchased, comes from discarded, used and worn out products. It includes aluminum pistons or body parts from junked cars, used aluminum cans and utensils, siding, awnings and other building products and old wire and cable. Sweated pig, which is scrap that has been sweated or melted into pig or ingot form, and obsoletc scrap, consisting of technologically obsolete aluminum parts, outdated inventory materials, produstion overruns and spare parts for machines and equinment nn lnnger boing uocd, are includerl as uld scrap. Aluminum from the non-ferrous fraction of shredded automobiles and the aluminum fraction from municipal solid waste (MSW) are listed as separate s.ategories; it is likely that these suurces will be more important in the future than at present.

Alumina from non-bauxite sources of recovered materials is the only type of potential recovered milterial that does not comply with the criterion for inclusion as a source. This category has been excluded because technology for recovering alumina from these sources is not likely to be commercial by 1987.

\title{
4.3.2 Selection of Process Subdivisions for Inclusion in the Target
}

The industry subdivisions are based on the historical and current use of recovered materials in the industry, the potential for their use between now and 1987, and the energy consumption levels in the industry.

Table 4.3-2 presents historical data on the consumption of purchased scrap by industry subdivision:

\author{
Primary Producers, \\ Secondary Smelters, \\ Independent Fabricaturs, \\ Nluminum fioundries, and \\ Chemical Produrers.
}

The consumption figures are in thnissands of short tons of scrap type for the period $19 / 0$ 1976. The industry subdivisions and sources of resnvered materialn hnve been summurizcd in Table 4.3-3 in a matrix form. A checked cell indicates that a defined source is presently providing recoverable material for a defined industry subdivision, or could realistically be expected to do so in the future. As mentioned earlier, the aluminum fraction of municipal solid waste and frum shredded automobiles have been identified as separate categories because they are likely to become more important sources in the future. 
Secondary Smelters $\begin{array}{llllll}1970 & 1971 \quad 1972 & 1973 & 1974 & 1975 & 1976\end{array}$

PURCHASED NEW SCRAP

Solits \& Clippings

Borings \& Turnings

Drosses and Skimmings

Foil and Others

SUBTDTAL

$\begin{array}{rrrrrrr}247 & 261 & 303 & 346 & 262 & 189 & 231 \\ 119 & 107 & 99 & 115 & 97 & 124 & 136 \\ 111 & 95 & 116 & 108 & 84 & 94 & 126 \\ - & - & - & - & - & \frac{15}{45} & \underline{25} \\ 477 & 463 & 518 & 569 & 443 & 422 & 518\end{array}$

PURCHASED OLD SCRAP

$\begin{array}{lccccccc}\text { Castings, Sheet \& Clippings } & 126 & 118 & 1 i 8 & 112 & 125 & 86 & 121 \\ \text { Aluminum Cans } & - & - & - & - & - & 7 & 8 \\ \begin{array}{l}\text { Sweated Pig } \\ \text { Cu-A7 Radiators and Others }\end{array} & 47 & 58 & 71 & 56 & 63 & 65 & 32 \\ \text { SUBTOTAL } & 173 & 176 & 189 & 168 & 188 & 190 & 271 \\ \text { TOTAL } & 650 & 639 & 707 & 737 & 631 & 612 & 759 \\ \text { Home Scrap } & \text { NA } & \text { NA } & \text { NA } & \text { NA } & \text { NA } & \text { NA } & \text { N.A }\end{array}$

Primary Producers Fabricators,

Foundries, Chemical Producers

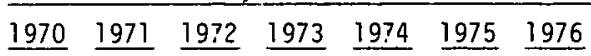

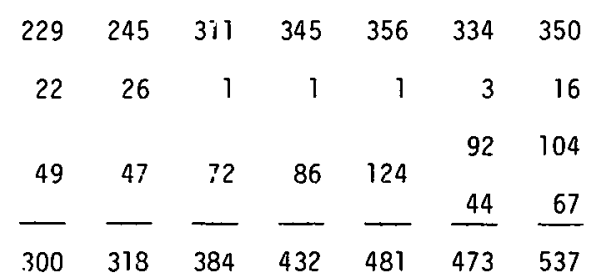

$\begin{array}{lllllll}10 & 20 & 34 & 65 & ? 1 & 28 & 35\end{array}$

$\begin{array}{llllll}-\quad & - & - & - & 77 & 101\end{array}$

$\begin{array}{lllllll}11 & 27 & 29 & 30 & 24 & 25 & 17\end{array}$

$\frac{-}{21} \div \frac{-}{67} \frac{-}{95} \frac{18}{148} \frac{17}{170}$

$\begin{array}{lllllll}321 & 365 & 447 & 527 & 576 & 621 & 707\end{array}$

NA NA NA NA NA NA NA \begin{tabular}{c} 
Total \\
\hline $1970 \quad 1971 \quad 1972 \quad 1973 \quad 1974 \quad 1975 \quad 1976$
\end{tabular}

$\begin{array}{rrrrrrr}476 & 506 & 614 & 691 & 618 & 523 & 581 \\ 141 & 133 & 100 & 116 & 98 & 127 & 152 \\ 160 & 142 & 188 & 194 & 208 & 186 & ? 30 \\ - & - & - & - & - & \frac{59}{370} & \frac{92}{1355}\end{array}$

$\begin{array}{lllllll}136 & 138 & 152 & 177 & 196 & 114 & 156\end{array}$

- $\quad$ - $\quad$ - $\quad$ - $\quad 84 \quad 109$

$\begin{array}{lllllll}58 & 85 & 100 & 86 & 87 & 90 & 99\end{array}$

$\frac{-}{194} \frac{-}{223} \quad \frac{-}{262} \quad \frac{50}{283} \quad \frac{47}{338} \quad \frac{71}{+11}$

$971 \quad 1004 \quad 1154 \quad 1264 \quad 1207 \quad 1233 \quad 1466$

NA NA NA NA NA NA INA

* Source: 1970-1975: U.S. Br: -eau of Mines Minerals Yearbooks.

1976: U.S. Bureau of Mines Minerals Yearbook Aluminum Preprint. 
TABLE 4.3-3

RE OVERAELE MATEEIAL SOURCE - INDUSTRY ISATRIX

ALUMINUM INDIUSTRY

Purchasad New Scrap

\begin{tabular}{|c|c|c|}
\hline $\begin{array}{l}\text { Solids } \\
\text { \& } \\
\text { Clippings }\end{array}$ & $\begin{array}{c}\text { Eorings } \\
\& \\
\text { Turnings }\end{array}$ & $\begin{array}{c}\text { Drosses } \\
\& \\
\text { Residues }\end{array}$ \\
\hline
\end{tabular}

Clippings Turnings Residues Other Scrap

$x$

3353

3354, 3355, Primary Procucers

3357

3341

SEcondary Srrelউer.s

3353,3354

3355,3357

Iridependent Fabricators

3361

Aluminum Found-ies

$\stackrel{\phi}{\phi}$

Chemical Producers

$x$

$x$

$X$

$x$

$x$

$x$

Castings,

Purchased 01d Scrap

Clippings

$\mathrm{Al}-\mathrm{Cu}$

A

Al Fraction

Pig Others

of MSW

Shredded
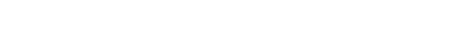

$X$

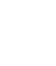

$x$

X

$x$ $x$

$x$

Source: Arthur D. Little, Inc. 


\subsubsection{Technical Considerations}

\subsubsection{Process Constraints}

Aluminum-based scrap is usually recycled by melting in gas or oil-fired reverberatory furnaces (10-100 short tons heat size), crucible furnaces (less than 5 short tons per hour), and induction furnaces (1-10 short ton heat size). There are no process technology constraints concerning the amount of scrap (percentage scrap in charge) that can be melted in each of these furnaces, although the different types of furnaces do provide different melting capacities.

The principal refining step in the recycling of aluminum-based scrap is the removal of magnesium by treating the molten metal with chlorine or aluminum fluoride. Any other impurities in the metal are usually controlled by dilution of the charge with pure metal. This need for dilution can, in many instances, limit the amount of impure scrap recycle.

The recycling furnaces are best suited for melting (as distinct from refining) and adequate scrap preparation is required to minimize contamination of the melt with impurities from the scrap.

Suitable technology is needed to separate aluminum from the non-magnetic fraction of shredded automobiles and from the non-ferrous fraction obtained in the treatment of municipal refuse. Techniques in various stages of development include water elutriation, heavy media separation, eddy current, etc.

\subsubsection{Product Quality Constraints}

Product quality constraints arise from having to meet specifications for composition. The composition limits and uses of the principal aluminum wrought and casting alloys are shown in Table 4.3-4.

\subsubsection{Recoverable Materials Quality Constraints}

Raw material constraints arise from the fact that the metal produced from the scrap has to meet a product specification; with the exception of magnesium removal, impurity levels are reduced by dilution with primary aluminum, and other alloying elements are added to attain the desired composition. Even well-segregated aluminum scrap is often contaminated with other metals, many of which can be considered impurities. Stainless steel is particularly troublesome because, unlike common steel, it cannot be separated from scrap magnetically, it is difficult to detect visually, and it dissolves in aluminum more readily than common steel. Free zinc is present in some borings, in jar covers, and as die castings. Magnesium, whether free or alloyed, is usually disadvantageous, since the principal alloys produced from scrap are permanent mold and die casting alloys which contain little magnesium (usually less than $0.1 \%$ ). Since about $85 \%$ of the recoverable material available to a smelter consists of mill products (high in magnesium content) the molten metal contains $0.5-0.8 \%$ magnesium, and has to he brought back into specification by demagging. Conversely, in the production of extrusion billets, magnesium and primary aluminum generally have to be added. Demagging is also not required for deoxidizer material (used in the steel industry) since magnesium is not critical.

Non-metallic contaminants in aluminum scrap such as paint, oil, plastic, insulation, and rubber are a major source of dir pollution. 


\section{ALUMINUM}

\section{Composition limits and uses of some aluminum wrought and casting alloys'}

(Weight-percent)

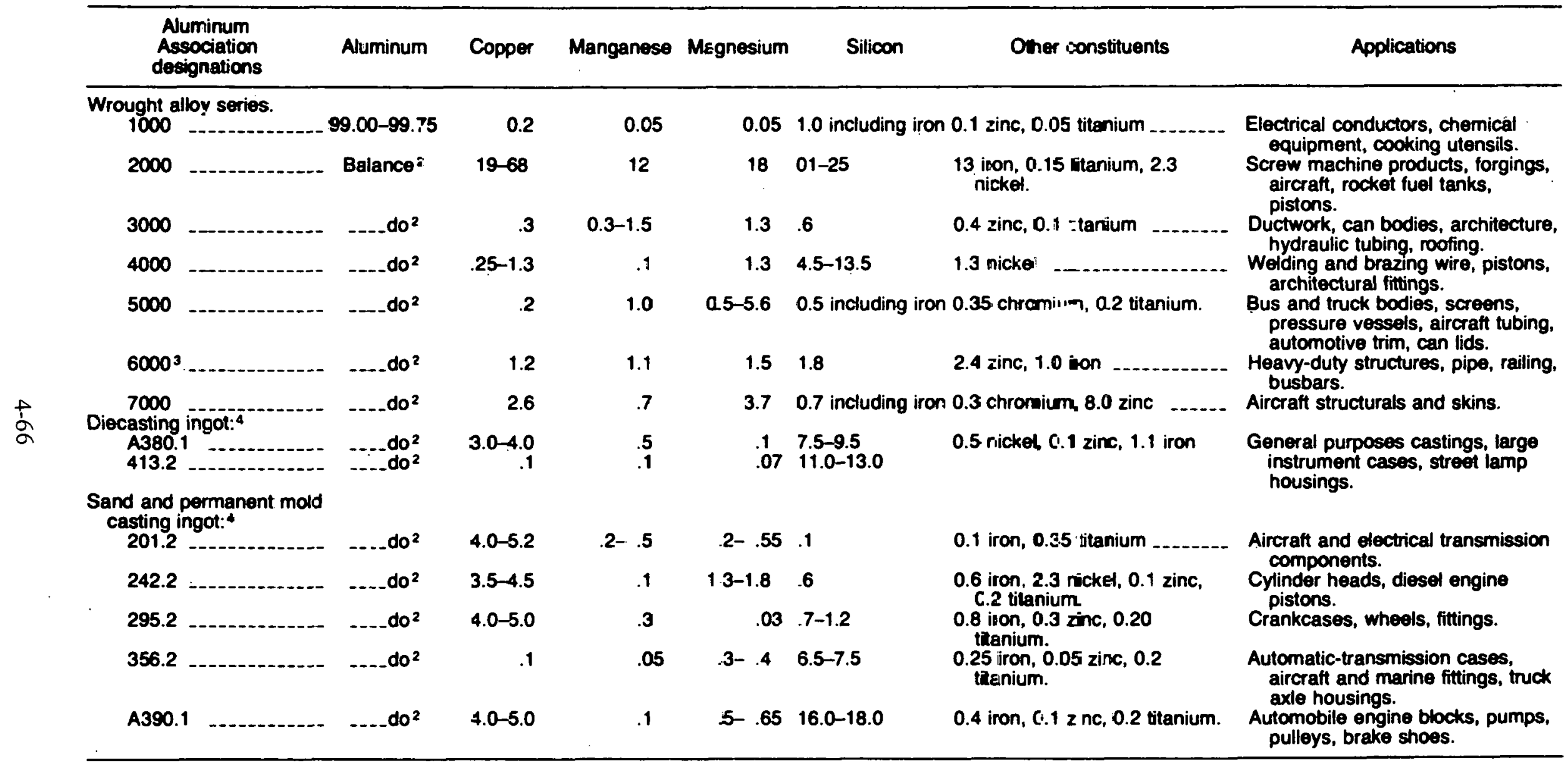

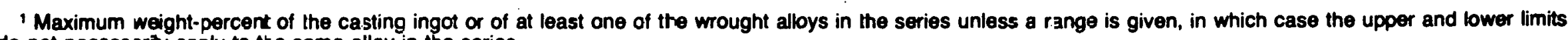
do not necessarty apply to the same alloy in the series.

2 Balance after deducting percent composition of specified alloying constituents plus other normal impurities. Minimum impurities for casting alloys are normally specified but are not shown in this table.

3 Alloy 6262 may contain 0.4 to 0.7 percent each of lead and bismuth

4 Composition of castings may differ from that of the ingot.

Source: U.S. Bureau of Mines Mineral Comnodity Frofiles - Aluminum, May 197B, p. 7. 


\subsubsection{Economic Considerations}

In setting a target for scrap recovery the analysis must take into account supply and demand, in both physical and economic terms.

The physical aspect of scrap demand concerns the process limitations on the amount of scrap that can be utilized. In the aluminum industry, unlike steel, there are no relevant physical demand constraints imposed by technology. The economic aspects of scrap demand relate to the price of scrap. The price of scrap is driven to a large extent by demand rather than by supply (i.e., inelastic to supply).

\subsubsection{Data Sources for Arthur D. Little Model}

The Arthur D. Little scrap model is designed to predict the volume of scrap that will be generated under a variety of scenarios. These volumes of scrap estimates are then used to calculate targets.

For data on scrap, we have relied on the U.S. Bureau of Mines Minerals Yearbook and Mineral Industry Surveys. Their detailed data on scrap consumption does not represent a full industry coverage. The Bureau reports that, in 1976, for example, full industry coverage would raise their aggregate figures by $18 \% .^{(1)}$ Using this figure, we multiplied new scrap and old scrap domestically consumed to a full industry equivalent. Aluminum can scrap and exports were assumed to be complete as reported, i.e., not requiring expansion to full coverage.

Data on aluminum ingot production and consumption were obtained from the Aluminum Statistical Review published by the Aluminum Association. Data on aluminum scrap and product prices were obtained from Metal Statistics.

The U.S. Bureau of Mines, Minerals Yearbook, reports the consumption of new purchased aluminum scrap, aluminum can scrap, and other old aluminum scrap, as well as on U.S. exports of aluminum scrap - which is chiefly old obsolete scrap. Ignoring year-to-year inventory changes, the sum of consumption and exports gives us available U.S. scrap supply.

The U.S. Bureau of Mines also reports aluminum scrap consumption by primary producers, secondary producers, foundries, fabricators, and chemical producers. The Bureau also presents calculated metal recovery from scrap.

\subsubsection{Aluminum Scrap Material Balance}

Table 4.3-5 shows the balance of sources and uses for aluminum scrap for 1976. This table is based on reported purchased scrap consumption expanded to full industry coverage for all categories except aluminum cans which was taken as reported. Aluminum scrap export data is as published by the Aluminum Statistical Review, and estimates for home or runaround scrap were provided by the Aluminum Association. ${ }^{(13)}$ We have assumed in this analysis that aluminum scrap that is exported is principally old scrap.

In 1976 purchased new scrap accounted for $68 \%$ of the supply of purchased scrap or $24 \%$ of the total scrap supply, i.e., purchased plus home scrap. In the category of old scrap, cans 
TABLE $4.3-5$

1976 MATERIAL BALANCE FOR ALUMINUM SCRAP

(Mitiions of Pounds)

Sources

\begin{tabular}{|c|c|c|c|}
\hline $\begin{array}{l}\text { Purchased Scrap } \\
\text { New Scrap } 1\end{array}$ & 2,490 & $\begin{array}{l}\text { U.S. Consumption } \\
\text { of Purchased Scrap }\end{array}$ & 3,482 \\
\hline ôld Scrap. & & $\begin{array}{l}\text { U.S. Consumption } \\
\text { of Home Scrap } 3\end{array}$ & 6,675 \\
\hline $\begin{array}{l}\text { Aluminum Cans } \\
\text { Other 01d Scrap }\end{array}$ & $\begin{array}{l}217 \\
946 \\
\end{array}$ & Exports $^{2}$ & 171 \\
\hline Purchased Scrap & 3,653 & & \\
\hline Home Scrap ${ }^{3}$ & 6,675 & & \\
\hline Total & 10,328 & Total & 10,328 \\
\hline
\end{tabular}

Source: Arthur D. Little, Inc. estimates derived from:

1 Aluminum, Preprint 1976 Minerals Yearbook.

2 Aluminum Statistical Review, 1976.

3 Communication, The Aluminum Association, May 8, 1979. 
accounted for $6 \%$ of the purchased scrap supply or $2.1 \%$ of the total scrap supply. Other old scrap such as obtained from junked car and appliances accounts for the remaining $26 \%$ of the purchased scrap supply or $9 \%$ of the total scrap supply. The domestic consumption accounted for slightly over $95 \%$ of the U.S. purchased scrap supply. It is to be noted that home scrap represents $64.6 \%$ of the total scrap supply.

\subsubsection{Potential for Increased Use of Recovered Material}

An examination of the statistics on scrap consumption trends (Table 4.3-2) an analysis to identify opportunities for increased solid waste utilization ${ }^{(2)}$, and a paper examining recycling opportunities $^{(3)}$ indicate that the potential for increased scrap utilization is in the area of old scrap. Battelle stated "according to industry sources well over $90 \%$ of the new scrap is recycled," and their analysis assumed that all new scrap is being recycled. ${ }^{(2)}$ Battelle also estimated that in 1969 , only $13 \%$ of the scrap available for recycling was actually being recycled. The amount of scrap available for recycle was calculated by Battelle on the basis of estimated life cycles of various aluminum-containing products. This approach yields estimates of tonnages of aluminum products becoming obsolete. The drawbacks of the life cycle approach are: (a) items such as aircraft may be exported and hence not scrapped within the United States; (b) it may be difficult to collect certain packaging items that are widely dispersed; (c) some obsolete items may not be scrapped; and (d) yield losses in recycling. Their approach, however, points out that old scrap is potentially attractive for augmenting scrap supplies. The main problem, however, lies in the collection of old scrap. The most promising sectors for improved recycling of old scrap are:

- Consumer recycling programs aimed at source segregation: Table 4.3-6 shows data on aluminum can reclamation for the period 1972-1976. Reclaimed cans represent approximately $25 \%$ of the cans being produced. We anticipate that this source will have significant potential for increased recycling. Most of the cans and other packaging items not collected go to the municipal solid waste stream.

- Recovery of aluminum from municipal solid waste: The potential for aluminum from MSW has been reviewed by Testin.(4) The amount of solid waste generated annually in the United States is estimated by the EPA at 136 million short tons. ${ }^{(4)}$ The aluminum content of this material is approximately $0.7 \%$, or about 2 billion pounds of aluminum. Present systems, which generally include some type of frontend processing followed by dense media or eddy current separation, will collect about half of the aluminum contained in the municipal solid waste stream. With present technology, lighter gauge aluminum, such as paper-backed foils as well as aluminum ends on steel beverage containers, are lost. Hence, the maximum amount of aluminum that could be recovered from this source if all the municipal solid waste were processed and the aluminum recovered is about a billion pounds. However, of nineteen U.S. locations with resource recovery systems (either on stream or under shakedown), only six have opted for aluminum recovery. These are expected to yield about 6 million pounds of aluminum annually from 10,000 short tons per day of refuse processed.(4) Nine other locations are under construction, with three providing for aluminum recovery and four in which aluminum recovery can be incorporated. These plants can process an additional $1.6 \%$ of the national refuse and recover an estimated 16 million pounds annually. In addition, 34 communities have systems under design or study or have requested construction funds, and another 75 are undergoing feasibility studies. If every system now being 
TABLE 4.3-6

\section{ALUMINUM CAN RECLAMATION DATA}

(1972-1976)

\begin{tabular}{ccc} 
Year & $\begin{array}{c}\text { Million } \\
\text { Pounds of Aluminum } \\
\text { Reclaimed }\end{array}$ & $\begin{array}{c}\text { Billions } \\
\text { of Aluminum } \\
\text { Cans Reclaimed }\end{array}$ \\
\cline { 2 - 3 } 1972 & $53^{1}$ & 1.2 \\
1973 & $68^{1}$ & 1.6 \\
1974 & $103^{1}$ & 2.3 \\
1975 & 180 & 4.0 \\
1976 & $212^{\star}$ & 4.8
\end{tabular}

\footnotetext{
*Represents incomplete industry coverage. ${ }^{1}$ Kepresents total industry; includes an additional 1,5 , and 18 million pounds in the years 1972, 1973, and 1974, respectively. This accounts for all aluminum cans collected by non-members of the Aluminum Association.
}

Source: Aluminum Statistical Review, 1976 
considered were implemented and all had aluminum recovery, an absolute maximum is 250 million pounds. A realistic maximum might be half as much or about 125 million pounds. Although these figures ${ }^{(4)}$ are a year old and the technology can be classified as emerging the analysis provides a perspective on the aluminum that can be recovered from this source.

The aluminum recovered is in the form of contaminated wrought product alloys comprising cans, rigid foil containers, extrusions, and lawn furniture with very few casting alloys. It should be emphasized that the technology for municipal waste treatment and aluminum recovery falls in the category of emerging vechnology. There is considerable uncertainty about the ability of many of the processes to operate on a sustained basis and about the amount of aluminum that will be available by 1987 . It is expected to be a relatively small portion of the scrap supply in 1987.

- Automotive scrap: The use of aluminum in cars has been steadily increasing, from about $50 \mathrm{lbs}$ per car ten years ago to about $114 \mathrm{lbs}$ per car in 1978. ${ }^{(5)}$ This trend is likely to continue in order to meet the 1985 goal of 27.5 miles per gallön required by the Energy Policy and Conservation Act of 1975. The use of aluminum in passenger cars in 1985 is estimated to range from $225-425$ pounds per car. ${ }^{(6)}$ Therefore, shredded automobile scrap should represent a substantial opportunity to recover aluminum. There are now about 180 shredders in the United States, shredding 9 million short tons, or approximately 5-7 million cars per year. ${ }^{(6)}$

\subsubsection{Description of Model}

The aluminum scrap model is, as stated before, designed to predict the volume of scrap that will be generated under a variety of scenarios. This volume is then used to calculate the target.

Table 4.3-7 lists the equations of the model, Table 4.3-8 defines the symbols used in the equations, and Table 4.3-9 gives the values of parameters in the equations. Equations (1) through (5) are used to predict the supply of scrap from different sources. Equations (6) through (9) forecast scrap consumption expressed in a variety of forms, e.g., gross weight as opposed to metallic. Equations (10) through (13) calculate the targets as the ratio of scrap consumption, variously expressed, to domestic aluminum production.

Equation 1: The amount of new scrap that will be generated is calculated by multiplying aluminum consumption by a prompt scrap generation rate. The historical generation rate is calculated by dividing new scrap consumption by aluminum consumption.

Equation 2: The amount of scrap that will be recovered from cans is calculated by multiplying the number of cans produced by a can reclamation rate and by the aluminum recovered per can. The can reclamation rate is the percentage of cans produced that are turned in at reclamation centers.

Equations 3 and 4: The amount of 'other old scrap' (all old scrap except cans) is estimated by multiplying the withdrawal rate by the aluminum inventory.

The aluminum inventory variable is a measure of the amount of aluminum existing within the domestic economy. The aluminum inventory is defined as the cumulative total of aluminum 
TABLE 4.3-7

EQUATIONS OF THE ALUMINUM SCRAP MODEL

\begin{tabular}{ccc}
$\begin{array}{c}\text { Equation } \\
\text { Number }\end{array}$ & $\begin{array}{c}\text { Endogenous } \\
\text { Variable }\end{array}$ & $\frac{\text { Explanatory Segment }}{1}$ \\
\cline { 1 - 2 } 2 & NEWSP & $b_{1} \times$ ALCON \\
3 & CANSP & $b_{2} \times b_{3} \times$ NOCAN \\
4 & WD & $b_{4}+\left(b_{5} \times\right.$ PSCP $)$ \\
5 & OLDSP & WD $\times$ INV \\
6 & DCRSP & $b_{6} \times$ CARSC \\
7 & SCON1 & CANSP + OLDSP + DCRSP + WST - EXP \\
8 & SCON2 & SCON1 + NEWSP \\
9 & SCON3 & $b_{7} \times$ SCON1 \\
10 & SCON4 & $b_{7} \times$ SCON3 \\
11 & TRGT1 & SCON1/DOMPRD \\
12 & TRGT2 & SCON2/DOMPRD \\
13 & TRGT3 & SCON3/DOMPRD \\
& TRGT4 & SCON4/DOMPRD
\end{tabular}


TABLE $4.3-8$

DEFINITION OF VARIABLES AND PARAMETERS

ALUMINUM SCRAP MODEL

\section{Endogenous Variables}

1 NEWSP

2 CANSP

3 WD

4 OLDSP

5 DCRSP

6 SCON1

7 SCON2

8 SCON3

9 SCON4

10 TRGT1

11 TRGT2

12 TRGT3

13 TRGT4
New Scrap

Scrap from cans

Scrap withdrawal rate

Other old scrap supply

Scrap created by increased aluminum in vehicles

U.S. old scrap consumption (gross weight)

U.S. total scrap consumption (gross weight)

U.S. old scrap consumption (metallic recovery)

U.S. total scrap consumption (metallic recovery)

Target 1 - 01d scrap gross weight

Target 2 - Total scrap gross weight

Target 3 - 0ld scrap metallic recovery

Target 4 - Total scrap metallic recovery

\section{Exogenous Variables}
1 ALCON
2 NOCAN
3 PSCP
4 INV
5 CARSC
6 WST
7 EXP
8 DOMPRD

Aluminum consumption Number of aluminum cans produced

Price of aluminum scrap

Aluminum scrap inventory

Number of cars and Class 1 trucks scrapped

Scrap recovered from municipal solid waste Scrap exports

Domestic aluminum production from all sources

\section{Parameters}
$1 b_{1}$
$2 b_{2}$
$3 b_{3}$
$4 b_{4}$
$5 b_{5}$
$6 b_{6}$
$7 b_{7}$

Prompt scrap generation rate Aluminum recovered per can Can reclamation rate Withdrawal rate constant Withdrawal rate slupe Additional aluminum scrap recovered from vehicle scrapped in 1987 over vehicle scrapped in $19 / 6$ Metallic recovery factor 
TABLE 4.3-9

VALUES OF PARAMETERS USED IN TARGET EVALUATION

ALUMINUM INDUSTRY

Item

Prompt scrap generation rate, $b_{1}$

ATuminum recovered in U.S. per can, $b_{2}$

Can reclamation rate, $b_{3}$

Withdrawal rate constant, $b_{4}$

Withdrawal rate slope, $b_{5}$

Additional aluminum scrap in U.S.

recovered from vehicle scrapped in 1987

over vehicle scrapped in 1976, $b_{6}$ $\underline{1976}$

0.203

0.0453

$23 \%$

0.001755

0.000218

$---$

Metallic recovery factor, $b_{7} \quad 0.845 \quad 0.845$

$\underline{1987}$

0.203

0.0330

$40 \%$

0. .001755

0.000218

38

consumed to date less the scrap recycled. Thus the inventory at the beginning of a year is cstimated by adding to the inventory at the beginning of the previous year, the amount of aluminum consumed less the scrap recycled during the previous year. Values for the inventory series were obtained for the period 1965-19'/4 from Synergy, Inc. (7) 'I'lue values for 1975 and 1976 were calculated by Arthur D. Little, Inc., using the procedure described in the Syntery report. The forecast of the aluminum inventory variable was based on a linear extrapolation of the series to 1987 . The fit is represented by the following equation:

$$
\begin{array}{ccc}
\mathrm{INV}=-876189.4+15029(\mathrm{t}) & \mathrm{R}^{2} \\
(39.4) & (47.4) & .996
\end{array}
$$

The withdrawal rate variable is calculated by dividing old scrap consumption by the aluminum inventory variable for each year from 1961 to 1976 . We have hypothcoized that the withdrawal rate is a function of price of scrap. We feel that the withdrawal rate is a more appropriate dependent variable than old scrap consumptiun. The major problcm with trying to estimate the supply ul uld scrap as a function of price is that the supply curvo ghifts down and nut. with time as the amount of aluminum in the economy increases. However, by normalizing according to this, inventory variable, it is hoped that the supply dynamics can be captured by econometric estimation.

$$
\begin{array}{ccl}
W_{D}-0.001755+0.000218 & P S C P & R^{2} \\
(3.259) & (3.378) & 0.533
\end{array}
$$


From the above equation, the supply price elasticity (Es) (calculated at the mean value of dependent and independent values) can be calculated as follows:

$$
E s=(d W D)(P S C P) /(d P S P)(W D)=(0.000218)(8.0344)(0.0035)=0.50
$$

Equation 5: The supply of other old scrap in equation (4) does not include the increasing contribution due to the increasing aluminum content of cars and Class 1 trucks. The number of vehicles scrapped (in 1987) is multiplied by the incremental aluminum content, (incremental aluminum is defined as the difference in aluminum recovered from a vehicle scrapped in 1987 over a vehicle scrapped in 1976) in order to capture the contribution to aluminum scrap supply due to the increased use of aluminum in cars and Class 1 trucks.

Equation 6: Old U.S. scrap consumption is calculated. First, the aluminum can scrap prediction from equation (2), the other old scrap prediction from equation (4), and the incremental vehicle scrap from equation (6) are summed to give U.S. old scrap supply. Next, an exogenous scrap export is deducted from scrap supply to give U.S. old scrap consumption.

Equation 7: Total U.S. scrap consumption is computed by summing old scrap consumption as predicted by equation (6) and new scrap as predicted by equation (1).

Equations 8 and 9: U.S. scrap consumption is put on a metallic recovery basis. In equation (8), old scrap consumption on a gross weight basis from equation (6) is multiplied by a recovery factor to give metal recovered from old scrap. Equation (9) performs an analogous operation to give metal recovered from total scrap.

Equations 10 to 13: The four targets are calculated. The numerator of the first and second targets are on a gross weight basis and the numerators of the third and fourth are on a metallic recovery basis. In all cases, the denominator is domestic secondary metallic recovery plus domestic primary production.

The numerator of the first target is from equation (6) and is old scrap gross weight; the numerator of the second is total scrap gross weight and is predicted from equation (7); the numerator of the third is old scrap metallic recovery and is from equation (8); and the numerator of the fourth is total scrap metallic recovery.

\subsubsection{Special Considerations}

The targets in Section 4.3.6 do not consider the effect of nationwide legislation such as "bottle" bills that now apply in several states (Connecticut, Iowa, Maine, Vermont, Michigan and Delaware*) i.e., requiring deposits on beverage containers. This legislation can be either single tier ('uniform') or 'two tier' (discriminatory). In the two tier law, a lower deposit is required on refillable containers i.e., glass than on non-refillable containers. Although, in general, such legislation is likely to increase the reclamation ratio as it promotes increased source segregation, concerns have been expressed that a two tier legislation may promote a shift toward refillable beverage containers. In Oregon, for instance, it is claimed that the reclamation ratio has in-

\footnotetext{
* The law has been passed, but will take effect only when neighboring states Pennsylvania and Maryland adopt a
} 'bottle' bill. 
creased to $80 \%$. Any. federal legislation requiring mandatory segregation of recyclable materials might have a similar effect. Also, action taken to reduce solid waste in dumps might also result in increased aluminum supply.

Another important consideration is that in the past the primary and secondary aluminum industries have generally catered to different markets. Traditionally, the primary industry bought little scrap and supplied the wrought products market, while the secondary industry was scrap-based and supplied the cast product market. Recently, the secondary aluminum industry has supplied almost $75-80 \%$ of the ingot metal for the foundry and die casting trades and has depended on the casting industry to consume almost $90 \%$ of its production. In the period 19651976 , the amount of scrap consumed by secondary smelters has increased by about $19 \%$, whereas that consumed by primary producers has almost doubled. Part of this increased scrap supply has been the result of consumer recycling programs for can reclamation. Since not much additional primary capacity is planned, it is likely that the competition for scrap between secondary and primary producers will increase. The primary industry now ships hot metal to automotive foundries. These shipments represent about $5-6 \%$ of the secondary aluminum capacity of about 2.45 billion pounds. There is also the possibility of primary producers increasing their market share in shipments to foundries. Recycling targets may well accelerate those structural changes that are already taking place.

\subsubsection{Target Estimation}

Recycling targets for 1987 have been developed for the aluminum industry utilizing the economic model developed in Section 4.3.4. The model is designed to predict the volume of scrap that will be available for recycling from different sources based on forecasts for exogenous variables used in the model. These volumes are then used to calculate targets. Because the projected targets are based on forecasts for exogenous variables, various possible scenarios have been considered.

Case I - Most Probable Exogenous Variables

(a) Projected aluminum consumption in 1987. The Economic Advisory Service at Arthur D. Little, Inc. assumes a $5 \%$ growth rate which has been selected for this case. The U.S. Bureau of Mines, on the other hand, projects a probable annual growth rate of $7.1 \%$ for the period $1976-1985$, slowing to $4.3 \%$ between $1985-2000{ }^{(8)}$ This averages $5.3 \%$ frum 1976-2000.

(b) Price of scrap. The price of scrap is assumed to remain constant in real terms (1967\$).

(c) Scrap from cans. We project that this source of scrap will provide 505 million pounds by 1987 , and that the aluminum reclaimed per can will decrease by $27 \%$ between 1976 and $198 \%$. The can reclamation rate is expected to increase to $40 \%$ of cans made in 1987 and aluminum can production will increase from 20.1 billion in 1976 to 38.5 billion in 1987.

(d) Aluminum imports. During the 1968-1977 period, the U.S. produced $94 \%$ of the primary aluminum it consumed ${ }^{(\theta)}$ However, industry plans to increase its primary metal production capacity by less than $10 \%$ in the next five years. In 1985, domestic production of primary aluminum metal will comprise about $85 \%$ of the U.S. primary metal demand and $80 \%$ of the demand in $2000{ }^{(8)}$ We have assumed that in 1987 , the United States will produce about $85 \%$ of its primary metal demand. In the model, the 
estimated scrap supply is based on aluminum consumption and the price of scrap from which secondary recovery is estimated. When the ratio of pr.imary production to primary plus imports is known, primary production can be determined.

(e) Scrap recovered from municipal solid waste. We have assumed a reasonably optimistic view of aluminum recovery from solid waste streams of 100 million pounds in 1987. There is considerable uncertainty, however, about the ability of resource recovery plants equipped for aluminum recovery to operate on a sustained basis and about the amount of aluminum scrap available from this source. We have, therefore, examined the effects of $+50 \%$ variation in supply from this source in the section on sensitivity analysis.

(f) Aluminum scrap inventory. The time series of inventory (defined as the cumulative total of domestic aluminum consumption, less the cumulative scrap reclamation to date) for the period 1965-1976, described in Section 4.3.4, was extrapolated to 1987 to yield an estimate of 43.1 billion pounds.

(g) Number of vehicles scrapped in 1987. The number of vehicles scrapped in a given year has been around $70 \%$ of the number of cars sold in that year. On the basis of an estimated 15.8 million cars and Class I trucks projected to be produced in 1987, and using the $70 \%$ factor for scrappage, we estimate that 11 million cars will be scrapped and $80 \%$ of these, or 8.8 million vehicles, will be processed. If each of these vehicles yields about 38 pounds more of aluminum than cars processed in 1976, 334 million pounds of aluminum will be added to the scrap supply. If current trends continue, more scrap will be available from this source after 1987. We expect this trend to continue up to the early 1990's, after which the scrap from this source is likely to level off, as cars scarpped will be post 1985 cars.

(h) Scrap export. Exports of aluminum scrap are expected to increase slightly but decrease as a percentage of scrap consumption. For 1987, scrap exports are estimated at 200 million pounds.

Case II - Identical to the base case except that the real price of scrap rises to 131 cents per pound (1975).

Although the ratio of the price of secondary ingot to the price of old scrap is about 3.5 in 1976 (base case scrap price of $7.55 \mathrm{c} / \mathrm{lb}$ ), it has been as low as 2 historically.

We have assumed that this ratio represents the minimum feasible margin under which secondary smelters may operate. A price of $13.1 \mathrm{~d} / \mathrm{lb}$ (1975) for scrap with the price of secondary ingot held constant in real terms simulates this minimum ratio. This results in an increase in withdrawal rate for old scrap of 0.00461 compared to the base case withdrawal rate of 0.0034 .

Case III -Identical to the base case, except exports in in 1987 drop to zero, to simulate a policy of restricting scrap exports.

Case IV -Identical to the base case, except that the new scrap generation coefficient is 0.19 compared to the base case coefficient of 0.206 . This represents about a $1 \%$ improvement in fabrication yields, which Battelle believes to be technically feasible and economically practicable. ${ }^{(11,12)}$ 
Recycling targets are presented in Table 4.3-10 for the 1987 scenarios. These targets represent ratios of:

(a) gross weight of old scrap

(b) gross weight of total scrap

(c) metallic recovery from old scrap, and

(d) total scrap metallic recovery to domestic primary production plus domestic secondary metallic production.

Table 4.3-10 shows that the recycle targets for total purchased scrap consumed increases $8.8 \%$ on a gross weight basis and $8.9 \%$ on a metallic recovery basis between 1.976 and 1.987 (hase. case). The target for old scrap consumed increases $18.0 \%$ on a gross weight basis and $18.3 \%$ nn a metallic recovery basis between 1976 and 1987 (base case).

A comparison of the targets for the various cases indicates:

- Increasing the price of scrap by $73.5 \%$ over the base price of scrap increases old scrap target by about $23.7 \%$ on a gross weight basis and on a metallic recovery basis by $23 \%$. The total scrap target increases approximately $7.5 \%$, both on a total scrap and metallic recovery basis.

- Reducing exports to zero increases old scrap target by about $9.3 \%$ on a gross weight basis and $9.0 \%$ on a metallic recovery basis. The total scrap targets increase $2.9 \%$ on a gross weight basis and $3.1 \%$ on a metallic recovery basis.

- Increasing the new scrap generation coefficient to 0.19 from 0.203 does not affect old scrap recovery targets. Total scrap recovery on a gross weight basis and recovered metal basis decreases by about $4 \%$ from the base case target.

\subsubsection{Sensitlvity of Target to Key Factors}

Table 4.3-11 shows the target in units selected by DOE for the target, i.e., the ratio of purchase scrap (prompt industrial and old, to total shipments or production of the primary and secondary industries.

The recycling targets presented in the previous section are directly affected by:

- Maximum withdrawal rate for old scrap, which is one of the most important determinants of old scrap supply. It has been as high as $0.53 \%$, thoigh it was only $0.34 \%$ in 1976 . We have examined the effect of the two-year maximum withdrawal rate of $0.48 \%$.

- Variation of new scrap generation coefficient.

- Scrap reclaimed from cans.

- Scrap recovered from municipal oolid wastc.

- Growth rate in consumption (a) $7 \%$ (b) $3 \%$.

- Level of imports. 
TABLE $4.3-10$

RECYCLING RATIOS FOR ALUMINUM INDUSTRY

FOR FOUR SCENARIOS - 1987

Scenario

Target Expressed as Ratio of

01d Scrap 01d Scrap " Total Scrap
Consumption Metallic Recovery Consumption Metallic Recovery to

Domestic Primary Production Plus Secondary Metallic Production

$\underline{1976}=$

0.100

0.0845

0.319

0.269

$1987=$

Case I

Base Case

0.118

0.100

0.347

0.293

\section{Case II}

Base Case except

Price of scrap $=13.1 \$ / 1 \mathrm{~b}$

$W D=0.00461$

0.146

0.123

0.373

0.315

Case III

Base Case except

Exports $=0$

0.129

0.109

0.357

0.302

Case IV

Base Case except

New Scrap Generation

Coefficient $=0.19$

0.118

0.100

0.333

0.281

TABLE $4 \cdot 3-11$

RECOVERED MATERIAL TARGET FOR ALUMINUM INDUSTRY - 1987

Recovered Matertal*

Domestic Primary \& Secondary Production

$\times 100=34.7 \%$

* Purchased scrap (prompt industrial and obsolete). 
The effect of these variables on the recycle targets is shown in Table 4.3-12.

- Increasing the withdrawal rate to the historic two-year high of 0.0477 increases old scrap consumption targets by $26.3 \%$ on a gross weight basis and $26 \%$ on a metallic recovery basis and total scrap consumption by $8.6 \%$ on a gross weight basis and $8.5 \%$ on a metallic recovery basis.

- Increasing new scrap generation rate by $10 \%$ increases total scrap consumption by about $6 \%$ on a gross weight basis and on a metallic recovery basis.

- Increasing scrap from cans by $10 \%$, or increasing the aluminum scrap recovered from MSW by $50 \%$ increases old scrap consumption target by $2.5 \%$ on a gross weight basis and $2.0 \%$ on a metallic recovery basis and the total scrap consumption by $0.6 \%$ on a gross weight basis and $0.7 \%$ on a metallic recovery basis.

- If imports increase to $20 \%$ of domestic primary metal demand (domestic primary plus imports), the old scrap target increases by $4.2 \%$ on a gross weight basis and $4.0 \%$ on a metallic recovery basis. The total scrap consumption target. increases by $4.3 \%$ un a gruss weight busis and $4.4 \%$ on à metallic recovery basis.

- For a $7 \%$ growth rate in consumption for the period, the old scrap consumption target decreases $18.6 \%$ on a gross weight basis and hy $19 \%$ on a metallic recovery basis. 'l'he total scrap target decreases by $3.7 \%$ on a gross weight basis and $3.75 \%$ on a metallic recovery basis.

- For a $3 \%$ increase in consumption of aluminum, the old scrap target increases by $30 \%$ on a gross weight basis and $29 \%$ on a metallic recovery basis. The total scrap consumption target increases by $13 \%$ on a gross weight basis and $13.3 \%$ on a metallic recovery basis.

\subsection{COPPER}

\subsubsection{Selection of Recoverable Materials}

Recoverable materials in the copper industry may come from a variety of solid wastes. In order to determine which of these should be included in the 1987 Recovered Materials Target, the criteria described in 4.1 Introduction have been used.

Table 4.4-1 lists all solid wastes containing copper, and notes which of them meet the criteria for inclusion in the 1987 Recovered Materials Target.

Materials meeting the criteria can be placed in the following categories:

- Nu. 1 wire and heauy copper scrap includes clean, uncoated, and unalloyed copper scrap containing more than $99 \%$ copper. This type of scrap normally does not require refining but is remelted and cast into shapes. Because of its high quality, this type of scrap is used by brass and bronze ingot makers, brass mills and secondary producers of unalloyed copper.

- No. 2 wire, mixed light and heavy scrap includes unalloyed copper relatively free of contaminants. The copper content normally is $92-96 \%$. This type of scrap is mainly consumed by brass and bronze ingot makers and secondary producers of unalloyed copper. 
TABLE $4.3-12$

SENSITIVITY OF TARGETS TO KEY FACTORS

ALUMINUM INDUSTRY

Factor

Target Expressed as Ratio of

\begin{tabular}{cccc} 
01d & 01d & Total & Total \\
Scrap & Scrap & Scrap & Scrap \\
Consumption & Metallic & Consumption Metallic \\
Recovery & & Recovery \\
\multicolumn{4}{c}{ to } \\
Domestic Primary Production plus Secondary \\
Metallic Production
\end{tabular}

1976:

0.100

0.0845

0.319

0.269

1987:

Base Case

Withdrawal rate is average of

historical two-year high $W D=0.00477$
0.118
0.100
0.347
0.293
0.149
0.126
0.377
0.318

New scrap generation coefficient rises $10 \%(.223)$

falls $10 \%(.183)$

0.118

0.118

0.100

0.100

0.368

0.325

0.311

Scrap from cans

rises 10\%

falls 10\%

0.121

0.116

0.102

0.098

0.349

0.349

0.295

Scrap from MSW

rises 50\%

falls 50\%

0.121

0.116

0.102

0.098

0.349

0.349

0.295

Imports as a ratio of primary

production plus imports

$$
\text { ratio } 20 \%
$$

ratio $10 \%$

0.123

0.114

0.104

0.096

0.362

0.333

0.306

Growth rate for aluminum

consumption

$$
\begin{aligned}
& \text { growth rate } 7 \% \\
& \text { growth rate } 3 \%
\end{aligned}
$$

0.096

0.153

0.081

0.129

0.334

0.392

0.282

0.332 
TABLE 4.4-1

\section{SELECTION OF RECOVERABLE MATERIALS}

\section{COPPER INDUSTRY}

Materials Possible

to Recover

No. 1 Wire \& heavy copper

No. 2 Wire, mix heavy and light

Does the Recoverable Material

Meet iriteria for Inclusion?

Composition of Red Brass

Railroad Car Boxes

Yes

No

Yellow Brass

$x$

Cartridge Cases \& Brass

$x$

Auto Radiators

$x$

Bronze

$x$

Nickel Silver \& Cupronickel

$x$

Aluminum Bronze

$x$

Low Brass

$x$

Refinery Brass

$x$

Low-Grade Scrap \& Residues

$x$

Aluminum Base Scrap

Nickel Base Scrap

Tin Basc Scrap

Zinc Base Scrap

$x$

$x$

$x$

$x$

Home Scrap

Smelter Waste Slag or Slag Tailings

$x$

sludgè

Skimming

Fume

Solution

Mine Waste

$x$

*Criteria for inclusion outlined in Section 4.1 . 
- Brass and bronze scrap includes various types of alloyed copper such as composition or red brass containing $82.5 \%$ copper; yellow brass containing $65 \%$; low brass scrap with $80 \%$; and bronze with $57.5 \%$ copper. These types of scrap are mainly consumed by brass and bronze ingot makers and brass mills.

- Other alloyed copper scrap such as railroad car boxes with $73 \%$ copper, consumed mainly by foundries; cartridge cases, $70 \%$, consumed almost entirely by brass mills; auto radiators, $70 \%$, consumed by brass and bronze ingot makers; nickelsilver and aluminum-bronze, consumed mainly by brass mills; refinery brass with $65 \%$ copper, consumed by primary refiners.

- Low-grade scrap and residues: this form of copper scrap, which is difficult to define, is estimated to contain an average of $34 \%$ copper and is consumed entirely by primary and secondary smelters making unalloyed copper. Although the copper content in this scrap category is low the copper is relatively free of unwanted contaminants, such as bismuth. A major part of low-grade scrap consists of armatures from electrical motors and consequently contains major amounts of iron besides the copper.

- Home scrap: the industry generates home scrap in various forms and, if it is not contaminated during processing and handling, it is generally recycled to $100 \%$ within the industry segments. Included in homescrap are the dusts generated in various air pollution control devices.

- Mine waste: this recoverable material is derived from leaching of mine waste dumps, that is, dumps containing mined material not classified as ore because the low grade of copper precludes economic processing in the beneficiation plant. Copper is recovered in the form of cement copper and is consumed entirely by primary smelters. The mine waste category does not include copper recovered from the leaching of copper concentrate.

Excluded as not meeting the criteria are the following materials:

- Sludge: The amount of copper contained in majority is not sufficient to make recovery economically viable by 1987 and is therefore excluded from the analysis.

- Skimming: Small amounts of skimmings are presently recycled. The amount is insignificant today, however, and no increase is foreseen before 1987.

- Slag: Waste smelter slags are usually low in copper (less than 1 percent). Recovery of copper from waste slag is unlikely in the foreseeable future and is excluded from the analysis.

- Fume: The amount of copper contained in fumes is insignificant and is excluded from the analysis.

- Solution: The amount of copper contained in solutions is insignificant and is excluded from the analysis.

- Aluminum-, Nickel-, Tin-, and Zinc-based scrap: These materials are recycled and the contained copper recovered. However, the recycling is not normally done within the copper industry. Therefore these materials are excluded from the 1987 Recoverable Materials Target for copper. 


\subsubsection{Selection of Process Subdivision for Inclusion in the Target}

Table 4.4-2 shows the consumption pattern of recoverable materials in the copper industry for the following four industry subdivisions:

- Primary Producers, including primary smelters and refiners producing refined copper,

- Secondary Smelters, producing refined copper, and brass and bronze ingot makers.

- Brass Mills

- Foundries, chemical plants and other manufacturers.

Table 4.4-3 shows that brass mills were the largest consumer of purchased copper scrap (i.e., all recoverable materials excluding home scrap and mine waste) consuming 662,454 short tons, which represents $44 \%$ of the total scrap consumption of $1,513,972$ short tons in 1976. Of this scrap, $95 \%$ was new and $5 \%$ was old scrap.

Primary producers used 425,790 short tons or $28 \%$ of total scrap consumed in 1976 . Of this, $44 \%$ was new and $56 \%$ old scrap. Secondary smelters consumed 356,786 short tons or $24 \%$ of total scrap consumption, of which $29 \%$ was new and $71 \%$ was old.

The remainder, 68,912 short tons or $5 \%$ of the purchased scrap consumed in 1976 went to foundries, chemical plants, and other manufacturers; $29 \%$ of this was new scrap and $71 \%$ old. A summary of the flow of purchased copper scrap in 1976, divided between new and old scrap is shown in Figure 4.4-1.

The historical (1970-1976) consumption of the recoverable materials meeting the criteria for inclusion in the 1987 copper recycling are shown in Table 4.4-4. This table also shows the average. dealers' buying prices for various types of purchased copper scrap in this period.

Table 4.4-5 shows the historical consumption of recoverable materials from 1970 to 1976 with consumption split among the four industry subdivisions.

\subsubsection{Technical Considerations}

\subsubsection{Process Constraints}

\subsection{Secondary Smelters}

Secondary smelters can be subdivided into two categories - those which can smelt and refine and those which are essentially remelters and refiners and have no smelting capability. Secondary smelters having smelting and refining capability can process a wide variety of scrap, low or high grade, old or new, to produce "black copper" which contains over $80 \%$ copper. The black copper is then fire or electrolytically-refined to produce secondary refined copper, or it is used to produce alloy ingot. These types of secondary smelters are $100 \%$ scrap based and have practically no process constraints in processing copper scrap.

A class of secondary smelters, mostly ingot makers, can process only those types of scrap which require no smelting or converting operations. They can only melt and fire refine high grade 
RECOVERABLE MATERIAL - SOURCE - INDUSTRY MATRIX -

COPPER INDUSTRY

Industry Subdivision

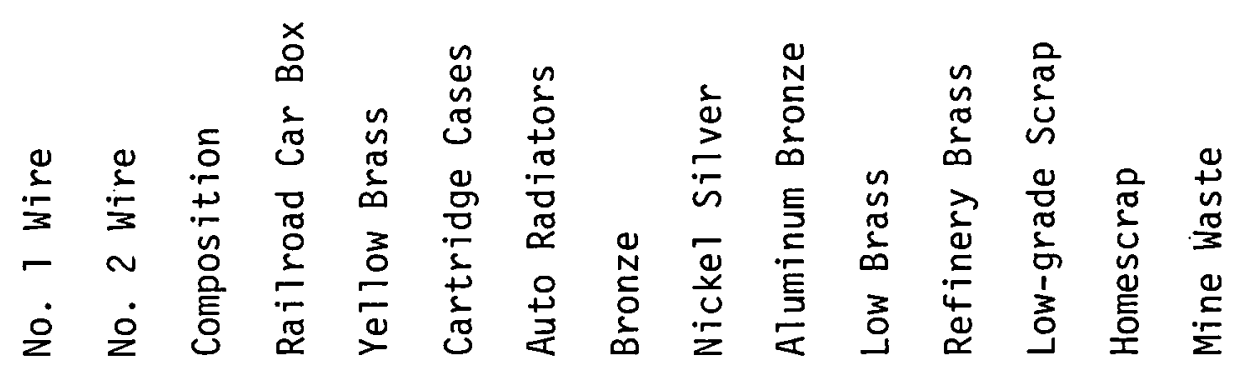

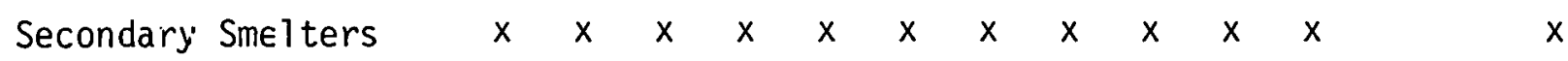

Primary Producers $x \quad x \quad x \quad x \quad x \quad x$

\section{Brass Mills}

Foundries

Chemical Plar.ts

$\begin{array}{llllllllllllll}x & x & & & & x & x & & x & x & x & x & & \\ x & x & x & x & x & x & x & x & x & x & x & & x & x\end{array}$

other Manuf.

Source: Arthur D. Little, Inc. 
TAELLE 4.4-3

CONSUMPTION OF RECIOVERABL इ MATERIALI 1976 - COPPER INDUSTRY ${ }^{7}$

Gross Weight in Tons)

Industry
Subdivision

Seccindary Smelters

Primary Producers

Brass Mills

Fouridries, Chemical

Plarits arid Other Manufacturers

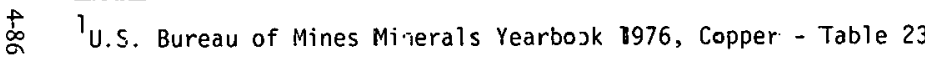
2 Net weicht of Copper, U.S. Bureau of Mines, Minera ts Kearbook 1976, Capper - Table 7.

\begin{tabular}{|c|c|c|}
\hline $\begin{array}{l}\text { No. } 1 \\
\text { Wire }\end{array}$ & $\begin{array}{l}\text { No. } 2 \\
\text { Wire }\end{array}$ & $\begin{array}{l}\text { Conpo- } \\
\text { gifion }\end{array}$ \\
\hline $27,0 \prec 8$ & 59,900 & 58.6055 \\
\hline $117,66 c$ & 128,340 & - \\
\hline 159,255 & 71,778 & - \\
\hline 29,18 & 9,928 & 4.518 \\
\hline
\end{tabular}

Railroad

Yeillow Cartridge

Box

Erass

46,27

Cases

Auto

57,823

$\frac{\text { Brorize: }}{19,320}$

Nickel Alum.

Alum. Low Refin. Grade

Low Home

Bronze Brass Brass

567

2,882

4,230

175,55

0

$4,217 \quad 33.791$

355

45,959

4,325

$3,0<8$

11), 258

593

82

449

1,455

$64 \quad 0$
Mine 2
Waste

126,144 


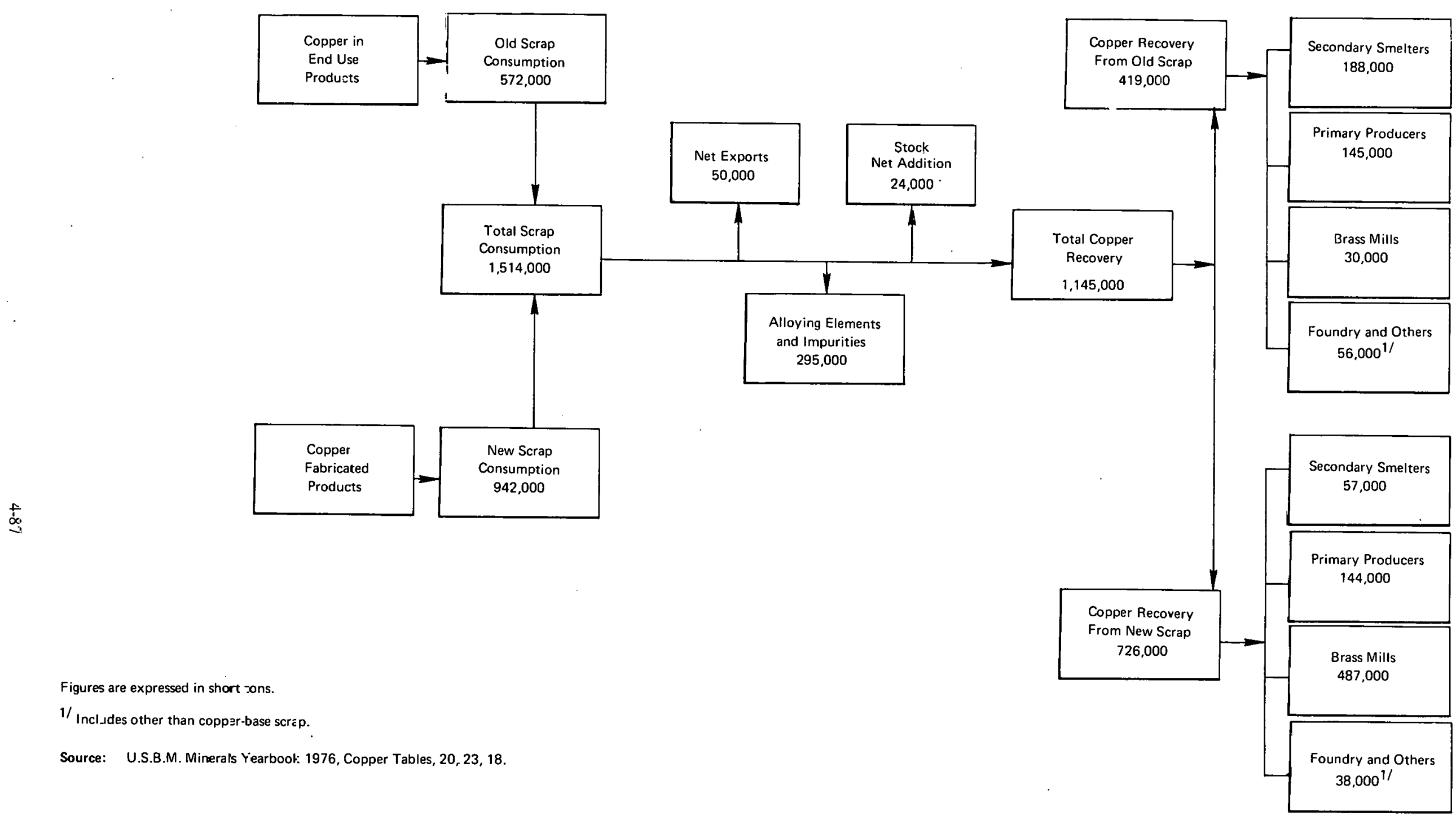

FIGURE 4.4-1 FLOW OF PURCHASED COPPER SCRAP IN 1976 
TABLE 4.4-4

PRICE/ ZUANTITY [IATA, FOR RECOVERABLE MATERIALS (1970-1976)

COPPER INDUSTRY

\begin{tabular}{|c|c|c|c|c|c|c|c|c|c|c|c|c|c|c|}
\hline \multirow[t]{2}{*}{$\begin{array}{c}\text { Recoverable } \\
\text { Material } \\
\end{array}$} & \multicolumn{7}{|c|}{$\begin{array}{l}\text { Consumption } 1 \\
\text { Gross Weight (short tons) }\end{array}$} & \multicolumn{7}{|c|}{ Price $(\$ / \text { ton })^{4}$} \\
\hline & 1975 & 1971 & 1972 & 4973 & 1974 & 1975 & 7976 & 1970 & 1971 & 1972 & 1973 & 1974 & 1975 & 1976 \\
\hline No. I Wire & $3048 \tilde{c}^{\circ}$ & 297752 & $\equiv 31470$ & $42: 75 ; 0$ & $4113+3$ & 285947 & 333134 & 921 & $(730)^{5}$ & $(880)$ & $(1140)$ & 1300 & $(810)$ & $(980)$ \\
\hline No. 2 Wire & $3463 C 0$ & 299872 & $£ 32476$ & 346366 & 3750083 & 242514 & 269946 & $789^{2}$ & $5 \overline{1}$ & 780 & 1004 & 1098 & 679 & 814 \\
\hline Composition & 84263 & 83716 & 87508 & 84692 & 31796 & 53968 & 63123 & $7 \geq 5^{3}$ & 578 & 591 & 817 & 875 & 649 & 681 \\
\hline Railroad Car & $280 \div 3$ & 10495 & 8994 & 9427 & $81: 07$ & 5668 & 6177 & 530 & $(440)$ & $(520)$ & $(740)$ & 750 & $(480)$ & $(580)$ \\
\hline Yellow Brass & 321138 & 307258 & $<04423$ & $4 C 5375$ & $358<91$ & 254769 & $3 \approx 3339$ & 480 & $(370)$ & $(460)$ & $(680)$ & 716 & $(420)$ & $(510)$ \\
\hline Cartridge Case & 116801 & 143946 & $\cdot 12684$ & ع90:53 & $77<50$ & 55062 & $7 \varepsilon 223$ & $(5-20)$ & $(400)$ & $(500)$ & $(710)$ & $(760)$ & $(460)$ & $(540)$ \\
\hline Auto Radiators & 56713 & 64985 & 73540 & 6.8774 & $69 \div 15$ & 53321 & $\epsilon \notin 081$ & 520 & $(400)$ & $(500)$ & $(710)$ & 800 & $(460)$ & $(540)$ \\
\hline Bronze & 34522 & 31306 & 32152 & 34575 & $32^{-} 53$ & 24114 & 24737 & $(430)$ & $(\equiv 10)$ & $(390)$ & $(630)$ & $(660)$ & $(380)$ & $(470)$ \\
\hline Nickel Silver & 22949 & 28161 & $3 \geq E 01$ & 32395 & $40^{-} 40$ & 42028 & 36958 & $(480)$ & $(\equiv 70)$ & $(460)$ & $(680)$ & $(720)$ & $(420)$ & $(510)$ \\
\hline Low Brass & $493=8$ & 54291 & 42481 & 29479 & 37.362 & 31317 & 50296 & $(6,25)$ & $(6,00)$ & $(590)$ & $(810)$ & $(860)$ & $(560)$ & $(650)$ \\
\hline Refinery Brass & 5570 & 695 & 6127 & 5112 & $9 \cdot 353$ & 3229 & 4230 & $(\angle 80)$ & $(370)$ & $(460)$ & $(680)$ & $(720)$ & $(420)$ & $(510)$ \\
\hline Lowgrade Scrap & $3818 € 2$ & 330495 & 315437 & 333938 & 311139 & 198629 & 254327 & 290 & $(-80)$ & $(240)$ & $(470)$ & 540 & $(210)$ & $(320)$ \\
\hline Home Scrap & NA & NA. & NA & NP & $N \mathrm{H}$ & NA & NA & & & & & & & \\
\hline Mine Waste 6 & $171 \subseteq 68$ & 154515 & 170993 & 159023 & 14608 & 144294 & 126144 & & & & & & & \\
\hline $\begin{array}{l}\text { 1USBM Minerals } \\
{ }^{2} \text { Metal Statistio } \\
{ }^{3} \text { Metal Statistio }\end{array}$ & $\begin{array}{l}\text { ok 1970- } \\
7, \text { p. } 10 \\
7, \text { p. } 10\end{array}$ & $\begin{array}{l}76, \text { Copp } \\
\text { Dealers } \\
\text { Dealers }\end{array}$ & $\begin{array}{l}\text { - Table } \\
\text { Lying } \mathrm{Pr} \\
\text { Lying } \mathrm{Pr}\end{array}$ & $\begin{array}{l}3(26) . \\
\text { e. }\end{array}$ & & $\begin{array}{l}{ }^{4} \text { Amer } \\
{ }^{5}(\quad) \\
{ }^{6} \text { Net }\end{array}$ & $\begin{array}{l}n \text { 'Yetal } \\
\text { thur } 0 . \\
\text { ght (st }\end{array}$ & $\begin{array}{l}\text { et } 1970 \\
\text { le Esti } \\
\text { ons) co }\end{array}$ & 77. & & & & & \\
\hline
\end{tabular}


TABLE 4,4-5

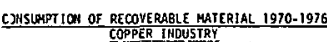

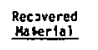
ive. 1 wi-e, Heaw

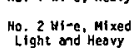
composition Rallroad Car bo Tellow Eross cortertige coses Auto Ractators

B Bronze Hickel Silver Low Brass

Ref Briners Bros

Lompradt Serap

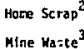

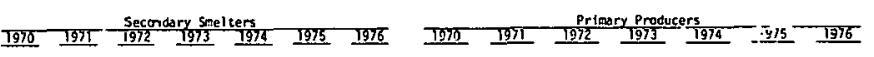
$22489 \quad 30774 \quad 32432 \quad 28058 \quad 31139025278 \quad 2028$ $\begin{array}{lllllll}76202 & 64391 & 64887 & 13699 & 7411 & 6017 & 59900\end{array}$ $78872 \quad 78419 \quad 2259 ; \quad 7916994917 \quad 49276 \quad 58605$ $\begin{array}{llllllll}2107 & 1534 & 271 & 2395 & 1365 & 1083 & 1852\end{array}$ $\begin{array}{llllllll}58730 & 64235 & 45488 & 60491 & 51993 & 38668 & 46217\end{array}$ $\begin{array}{lllllll}358 & 146 & 204 & 144 & 100 & 75 & 195\end{array}$ $\begin{array}{lllllll}49359 & 55502 & \mathbf{3} 328^{\circ} & 58220 & 50026 & 45659 & 57823\end{array}$ 27683 25530 $\quad$ :365:- $28144 \quad 26112 \quad 19642 \quad 19920$ $\begin{array}{llllllll}4034 & 4335 & 3571 . & 4681 & 4203 & 2785 & 3085\end{array}$

$\begin{array}{lllllll}478 & 284 & 425 & 917 & 583 & 339 & 567\end{array}$ $\begin{array}{lllllll}1535 & 4201 & 3711 & 3359 & 2644 & 2329 & 2882\end{array}$ $\begin{array}{lllllll}5125 & 93606 & 32124 & 59176 & 59127 & 56290 & 78712\end{array}$

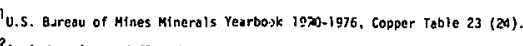

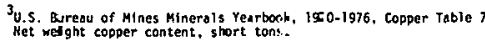
$\begin{array}{lllllll}6540 & 615 & 6127 & 5112 & 9953 & 3229 & 4230\end{array}$

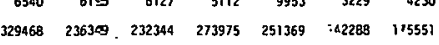

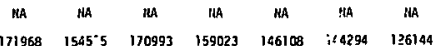

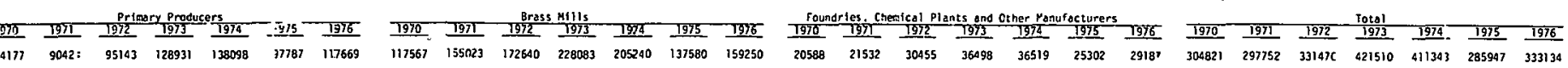
$\begin{array}{lllllll}35234 & 39666 & 56882 & 60275 & 59672 & 43061 & 71778\end{array}$ $256618 \quad 236967 \quad 333348 \quad 3400110290061 \quad 209592 \quad 269070$ $\begin{array}{lllllll}116443 & 143800 & 112480 & 88909 & 77550 & 55987 & 78020\end{array}$

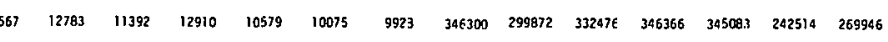
$\begin{array}{llllllllllllll}5789 & 5297 & 4911 & 5523 & 6879 & 4692 & 4513 & 84263 & 83716 & 8750 & 84692 & 81796 & 53968 & 63123\end{array}$ $\begin{array}{llllllllllllll}25966 & 8911 & 6282 & 7032 & 6741 & 4595 & 4325 & 28073 & 10995 & 8994 & 9427 & 8107 & 5668 & 6177\end{array}$ $\begin{array}{llllllllllllll}5783 & 6056 & 5593 & 4774 & 7237 & 6142 & 8004 & 321131 & 307250 & 404428 & 405375 & 358291 & 254769 & 323339\end{array}$ $\begin{array}{llllllll}116801 & 143948 & 112686 & 89053 & 7745) & 55052 & 78223\end{array}$

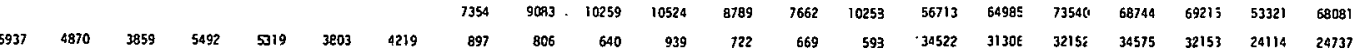

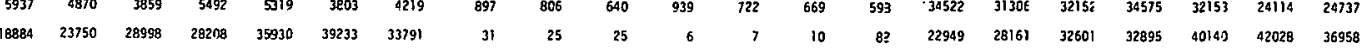

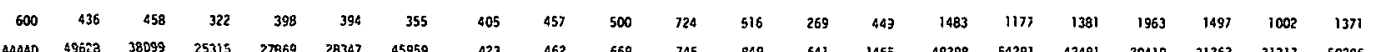

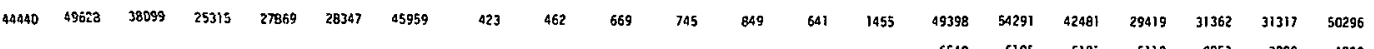
$6550 \quad 6195 \quad 612: \quad 5112 \quad 9953 \quad 3229 \quad 4230$

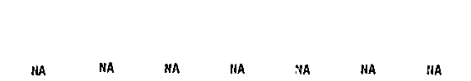

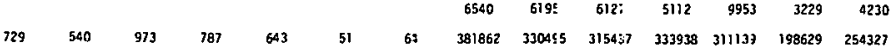

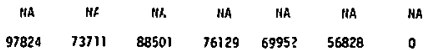

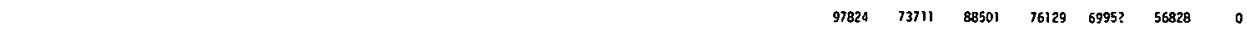


scraps because of process equipment limitations. Most low grade scraps require some form of melting and converting, or converting and complex fire refining; whereas high grade scrap can be just smelted and fire refined in a conventional manner.

In general, secondary smelters are $100 \%$ scrap based and can process a wide range of copper scrap. The process limitations depend on the type of equipment installed in the smelter.

\subsection{Primary Producers}

Primary refiners can producc anodes by melting high-grade scrap. The anodes are in turn used to produce electrolytically-refined copper. Although there are no process restraints on refining of high-grade scrap, there are definite limits to scrap utilization in the smelting process. Primary smelters, like secondary, purchase large amounts of low-grade scrap and residues for upgrading to blister. 'l'he scrap is normally added in the converter step. Smelting furnaces can, in principle, melt scrap, but they are designed for handling finely-powdered concentrates and nnt. heavy, bulky scrap. It is not likely that the furnaces will be altered for the feeding of substantial yuantities of heavy scrap in the near term .

Since there are no external heat inputs, the scrap handling ability of a converter is determined by its ability to absorb heat losses incurred from addition of scrap into the molten matte this in turn is determined by the mat.te grade. Assuming the avcragc mattc grade in the U.S. industry to be $35 \%$, the maximum consumption of recoverable materials in the converter step would be approximately $35 \%$ of blister output.

\subsection{Brass Mills}

Brass mills melt copper, copper scrap, a small amount of recycled alloy ingot, and alloying material into billets, slabs, or cakes. Frnm these they then fabricatc tubc3, sheets, rods, and mechanical wire. Because brass mills usually have only melting facilities, they purchase clean and well-sorted scrap and do not recycle any low-grade scrap or residues; the amount of old scrnp consumed is very small. Brass produced from scrap is, however, interchangeahle with brass produced from refined metal if alloying constituents are comparable.

\subsection{Foundries, Chemical Plants and Other Manufacturers}

Foundries, like brass mills, are basically remelters and as such have very limitcd ability to consume low-grade scrap and residues. Scrap consumption in foundries is based on high-grade unalloyed copper scrap used as a substitute for refined copper. For such high-grade scrap there are no process restraints. Consumption of lower grade scrap is limited to scrap with a desired and well-known composition.

Consumption of sopper scrap by powder manufacturcra, chrmical plants, and ullitr manu facturers, such as the steel and aluminum industries, is limited and will have no impact on the target setting for recoverable materials.

\subsubsection{Product Quality Constraints}

As secondary refined copper is a perfect substitute for primary refined copper and as brass and foundry products produced from scrap are interchangeable with brass produced from refined metal if alloying constituents are comparable, there are no product quality constraints that will have any impact on the 1987 recycling target. In specific plants, however, the requirement for impurity dilution will constrain the type and amount of recovered material that can be used. 


\subsubsection{Recoverable Materials Quality Constraints}

Purchased Scrap: Almost any type of copper-containing material can be reclaimed and used in the production of secondary copper, regardless of age, condition, or degree of contamination. Quality constraints must, however, be recognized when discussing the various consumers.

High-grade copper scrap can theoretically be used in all segments of the industry, although most of it is consumed by brass mills, ingot makers, and foundries, all remelters with process constraints on using low-grade scrap.

Low-grade scrap and residues can only be used by primary, and to a much lesser degree, secondary smelters because upgrading is required. Brass and bronze scrap cannot be used to produce refined copper. This type of scrap is consequently limited to brass mills, ingot makers, and foundries.

Home Scrap: There are no quality constraints to the recovery of copper in home scrap as long as the quality of the home scrap is well-defined. Included under the term home scrap are such recoverable materials generated within the consuming plant such as cuttings, grindings, trimmings, flue dust, spills, and sweeps.

Mine Wastes: Copper in mine wastes is recovered by leaching of mine waste dumps and precipitation on iron to form cement copper. Because of the iron and other impurities in the cement copper, and because the primary producers all of the cement copper, consumption is constrained to primary smelters.

\subsubsection{Economic Considerations in Recycling}

As with other metals, copper can be recovered from old and new scrap sources. New scrap is generated automatically from fabricating activities in copper processing and fabricating industries. Thus, the supply fluctuates with the level of copper-based production and is relatively independent of price considerations. Old scrap, on the other hand, represents recovery of the copper embodied in discarded materials, and some degree of price responsiveness in its availability is to be expected.

As Table 4.4-6 indicates, old scrap has played a significent, but not dominant role as a balancing agent in U.S. refined copper production. Since the production of copper ore is relatively inflexible in the short run, and new scrap production is largely determined by activity levels in the copper fabricating industry, old scrap plays an important role in meeting fluctuating levels of excess demand in the system. Because scrap copper can be recovered with varying degrees of difficulty from different materials, it is natural to expect some degree of price responsiveness from old scrap suppliers.

The major sources of secondary scrap copper are No. 1 and No. 2 wire, yellow brass, and lowgrade scrap, with cartridge cases and composition/red brass playing a significant but secondary role. Since the high-exploitation sources (No. 1 and No. 2 wire) are usable at low cost, most expansion in periods of heightened demand will come from the marginal sources at intermediate and low levels of exploitability (yellow. brass/ cartridge cases and low-grade scrap/composition, respectively). The resulting relatinnship between scrap price and supply levels is likely to be 
TABLE 4.4-6

COPPER PRODUCTION BY REFINERIES

(BY INPUT SOURCE), 1974-1976

$\begin{array}{lrrr} & \underline{1974} & \underline{1975} & \underline{1976} \\ \begin{array}{lrrr}\text { Total Production ('000 short } \\ \text { tons) }\end{array} & 2,068 & 1,714 & 1,826 \\ \text { Primary Refined (\%) } & 80.0 & 84.2 & 84.2 \\ \text { Secondary Refined (\%) } & 20.0 & 15.8 & 15.8 \\ \text { New Scrap (\%) } & 11.1 & 8.1 & 7.9 \\ \text { 01d Scrap (\%) } & 8.9 & 7.7 & 7.9\end{array}$

Source: U.S. Bureau of Mines, Mineral Industry Surveys, "Copper in 1976", Apri1 15, 1977, p. 4.

discontinuous. Nevertheless, it is useful for long-range policy planning to have some estimate of the average price elasticity of the secondary scrap supply. The best available numbers are provided by three econometric models of the copper industry that use recent time series data.

The three models are Furecasts and Analysis of the Coppcr Market, prepared for the General Services Administration by Charles River Assnciates, Inc., in May 1973 (henceforth referred to as CRA); An Economic Analysis of the Secondary Copper Industry in the United States, a Ph. D. disscrtation submitted to the College of Earth and Mineral Sciences, Pennsylvania State University, in August 1976 by Elizabeth S. Bonczar (henceforth PS); and An Econometric Model of the World Copper Industry by F.M. Fisher, O.H. Cootner, and M.N. Bailey (originally published in The Bell Journal of Economics and Management (1971)) (henrefnrth FCB). The evidence provided by each of these models is regarded as relevant, because all use acceptable corrections for the simultaneity problem and all make use of the Fair technique.*

The general approach to estimation in the three models is similar, but differences in estimates of short- and long-run price elasticities of copper scrap supply in the United States result from differences in the design of the estimating equations, the periods over which the estimates are taken, and the unit of time used for the econometric exercises. Although no final judgment on the relative quality of the three models can be made, it appears that the model of the market incorporated in the CRA and FCB approaches is superior to that in the PS effort.

The short-run estimates for the scrap supply elasticities do not differ widely for the three models: CRA (0.49), FCB (0.42), PS (0.24). Using the reported standard errors for the CRA and $\mathrm{FCB}$ results, it is also possible to estimate the interval of values within which it is $95 \%$ probable that the true short-run elasticity (SRE) lies by the standard statistical criteria: CRA $(0.30 \leq \mathrm{SRE}$

* See Section 2.1.6 on econometric estimation procedures for a discussion of these points. 
$0.68)$, FCB $(0.20 \leq \mathrm{SRE} \leq 0.65)$. If both results are considered as equal in value, any estimate of the SRE between 0.20 and 0.68 cannot be rejected as implausible.

The long-range estimates are quite different. The best estimates of long-run elasticities (LRE's) are quite different: CRA (0.66), FCB (0.31), PS (0.24). The CRA specification seems somewhat superior to the others, but the difference does not seem sufficient to generate such divergent long-run estimates. In any case, the existing estimates serve to define the range within which an appropriate estimate of the LRE's may be supposed to lie.

\subsubsection{Special Considerations}

One of the special considerations in recycling of copper is the proposed governmental pollution control regulations and their impact on the industry structure and the ability of the industry to process scrap and low quality materials in compliance with these regulations.

\subsubsection{Target Estimation}

Shown in Table 4.4-7 is the historical consumption of the various forms of recoverable material being considered for the 1987 target. The quantities are given in short tons of contained copper and are derived from Table 4.4-4 by applying the average figures for contained metal in the various forms of recoverable materials discussed in Section 4.4.1.1. Table 4.4-7 also gives the historical recycling ratio, which is defined as the ratio of recovered copper to (recovered copper plus primary production) expressed as a percentage for the period 1970-1976. The recycling ratio over this period has a mean value of $47.0 \%$, a maximum value of $49.4 \%$, and a minimum value of $44.8 \%$. Consequently, the recycling ratio has been relatively stable between 1970 and 1976 .

The econometric results discussed in Section 4.4.4 are useful for projecting copper recovery given projections of scrap price and the size of the recoverable copper reservoir can be provided. Calculation of the recycling ratio (recovered copper/(recovered copper plus primary production)) also requires a projection of primary refined copper production. This report employs the projected increase rates for scrap price and primary production which are found in the Arthur D. Little, Inc., report "Economic Impact of Environmental Regulations on the United States Copper Industry," submitted to the U.S. Environmental Protection Agency in January 1978. The Arthur D. Little projections also incorporate the anticipated impact of pollution abatement legislation during the coming decade. The increase in the recoverable copper reservoir has been calculated using an observable average lag of approximately 20 years between the use of copper in capital equipment and its release through scrapping. The estimated rate of increase from 1974 to 1987 has been extrapolated from data on copper consumption during the period 1954-1967.(1) The estimated short-run scrap price elasticities for the CRA/FCB models are similar, while the longrun elasticities diverge considerably: 0.45 is adopted here as a reasonable intermediate figure. The CRA estimate of the elasticity of recovery from the available reservoir $(0.55)$ is also employed. With these price, production, and reservoir growth rate projections (summarized in Table 4.4-8), and the CRA/FCB estimates of response elasticities for scrap price and reservoir recovery, the copper recovery level is projected to increase $26.3 \%$ through 1987 . Table $4.4-9$ shows the target in units selected by DOE for the target, i.e., recovered material as a percentage of total shipments or production of the primary and secondary industries. As Table 4.4-10 reveals, the target does differ significantly from the typical ratio that has prevailed during the 1970's. 
TABLE 4.4-7

$\frac{\text { IISTORICAL RECYCLING DATA - 1970-1976 }}{\text { COPER }}$

COPPER' INDUSTRY

(Short Tons Contained Copper)

Recovered
Material

No. 1 Wire

$-97 C$

19:1

1972

1973

1974

1975

$\underline{1976}$

No. 2 Wire

Composition

$304,51 \epsilon$

297,454

331,139

421,178

410,932

285,661

332,801

$231.522 \quad 281,880$

$31 \bar{c}, 527$

325,534

$\vdots 24, \vdots 78$

227,963

253,749

$7 \check{c}, 194$

69,871

$67,<82$

44,524

52,076

Railroad Car Boxes

$20: 493$

7,661

$\epsilon, 566$

6,832

$5, \subseteq 18$

4,138

4,509

Yellow Brass

208.735

199,718

262,875

263,434

$\approx 32, \varepsilon 89$

165,600

210,170

Cartridge Dases

Auto Radiazors

$81.761 \quad 100,7 \in 2$

78,879

$62,3.37$

$54, c 15$

39,243

54,756

$39.699 \quad 45,490$

51,478

48,121 .

48,451

37,325

47,657

Bronze

$\stackrel{+}{b}$

Nickel-Silver

19.850

18,0011

18,487

19,881

18,488

13,866

14,224

21,191

21,332

$26,[9]$

27,318

24,023

ATuminum-Bronze

964

$7 \in 5$

898

1,276

$\subseteq 73$

651

891

Low Brass

39.518

$43,4 \Xi 3$

33,985

23,535

$25, C 90$

25,054

40,237

Refinery Brass

4.251

$4,0 乞 7$

3,323

6,469

2,099

2,750

$107,249 \quad 113,533$

105,787

67,534

86,471

Mine Waste

171,968

154,515

170,993

159,023

146,108

144,294

126,144

TOTAL

COPPER RECOVERED

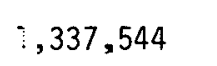

$1,353,445$

$1,472,444 \quad 1,539,395$

$1,473,271$

$1,055,270$

$1,250,458$

TOTAL PRIMARY*

$1,593,126$

$1,437,267$

$1,702.240$

$1,709,465$

$1,508,550$

$1,229,084$

$1,113,164$

RECOVERED COPPER

.456

.485

.464

.476

.497

.448

.469

RECOVERED COPPER

AND PRIMARV PRODUCTION

*Excluding mine waste - defined as secondary.

Source: U.S. Bureau of Mines Minerals Yearhook 1970-1976, Copper. Arthur [. Lit:le, Inc. estirates. 
TABLE 4.4-8

COPPER INDUSTRY ESTIMATED INCREASE (1974-1987)

$\begin{array}{ll}\text { Primary Refined Output } & 21.5 \% \star \\ \text { Scrap Price } & 17.0 \% \star \star \\ \text { Recoverable Reservoir } & 34.0 \% \star \star \star\end{array}$

* Economic Impact of Environmental Regulations on the United States Copper Industry, Report to the U.S. EPA by Arthur D. Little, Inc., January, 1978, Table XII-7, p. XII-9.

** Op. Cit., Table XII-9, p.XII-25.

*** Metal Statistics, (1955, 1962, 1971, 1976)

TABLE 4.4-9

RECOVERED MATERIAL TARGET FOR COPPER INDUSTRY (1987)

Recovered Material*

Domestic Primary \& Secondary Production

$\times 100=50.4 \%$

*Prompt industrial and obsolete scrap, plus precipitate copper from mine waste. 
TABLE 4.4-10

COPPER RECYCLING RATIOS, 1970-1976*

$\begin{array}{lr}\text { Year } & \text { Ratio } \\ 1970 & 45.6 \% \\ 1971 & 48.5 \% \\ 1972 & 46.4 \% \\ 1973 & 47.4 \% \\ 1974 & 49.4 \% \\ 1975 & 44.8 \% \\ 1976 & 46.9 \%\end{array}$

Mean Ratio: $47.0 \%$

* Ratios derived from Table 4.4-7. 


\subsubsection{Sensitivity of Target to Key Factors}

Key factors that could have a positive effect on the 1987 target are:

- Rising energy costs will probably be the most important commercial incentive for recycling of more copper in the near future. Industry sources estimate that energy consumed per pound of refined metal recovered from low-grade obsolete scrap is approximately one-third that needed to produce refined copper from virgin material.

- The high level of industrial activity during the 1960's will result in a surge of copper scrap entering the market in the 1980's. Regulatory and public pressure could influence increased recycling.

- Further regulations governing the mining industry which would drastically increase the cost of primary production.

- Changes in freight rates might favor scrap transportation.

Kcy factors that could have a negative effect on the 1987 target are:

- Legislative action that would reduce the amount of recycling, such as sale of emergency copper stockpiles.

- A decrease in the amount of less desirable scrap recycled. All industrial, or new scrap is already recycled to almost $100 \%$ which means that any change in the recycling ratio would have to be from obsolete or old scrap. A Battelle study' ${ }^{21}$ shows that the approximate compusition of old scrap that is not recycled is:

$16 \%$ - End uses in which copper is widely dispersed, as in consumer durables.

$15 \%$ - Magnet wire used primarily in small electric motors.

$10 \%$ - A copper used as sacrificial additives that disappear during processing.

$8 \%$ - Unrecovered cartridge brass, often spread out over large areas.

$51 \%$ - "Other brass" including thousands of relatively minor end uses.

Because the collection, sorting, and preparation of the above categories of copper scrap are extremely labor-intensive and costs for transportation are high, recycling of these categories is very dependent on scrap prices, particularly on a short-term basis. The only situation that could have an important positive influence on the recycling of this scrap would probably be a significant increase of scrap prices nver the long term, and no such long-term stability is evident in the scrap price historical data. Labor and transportation costs are likely to increase further, and reduction in recycling of the above described scrap categories could be the result by 1987 . 


\section{$4.5 \mathrm{ZINC}$}

\subsubsection{Selection of Recoverable Materials}

Recovered material for the zinc industry means zinc recovered from any waste. This includes both materials generated in the manufacture of zinc products (new scrap) and post consumer materials (old scrap) that have been collected or recovered from discarded products. The criteria that have been used to determine if a particular source of material should be considered in the context of this study include:

- The quality, dispersion, and quantity of existing sources;

- Any changes in existing sources for the period to 1987;

- Any potential new sources;

- Any wastes listed in the National Energy Conservation Act, such as mine wastes;

- Any sourcc that may provide recovered material to replace any virgin materials in any zine industry subdivision.

Materials specifically excluded are:

- Any wastes not among those listed in the National Energy Conservation Act;

- Any wastes that are not expected to be used as a recovered material by 1987 for whatever reason - technical, economic, or institutional.

The sources screened for inclusion as recoverable material are listed in Table 4.5-1. Each type of scrap is checked against the criteria for inclusion to see if it should he inclunded as a recoverable material in the target. Many of the new zinc scraps, hnth purchased and home scrap, are included in the target setting; these are most often recycled at present. For example, the zinc supplier to a galvanizer generally contracts to buy back all zinc-containing residues. The galvanizer residues repurchased under these agreements includes drosses, skimming, ashes, and sal skimmings. Zinc die casters generally do not enter into such contracts, but their scrap is generally recycled as home scrap or sold to dealers for recycle. Some chemical residues and flue dusts are also recycled as sources of recoverable materials. The main new stream source is electroplating liquors, which will not be reprocessed for their zinc content by any zins industry suhsertor hefnre 1987. Other industry sectors might reprocess these elestroplating solutions for their more valuable metal content.

The zinc contained in brass scrap is not included in the zinc target, primarily because it would result in double counting. Brass has its own targets (see discussion of the copper industry, Section 4.4) and zinc is included there. 'The concern about double counting zinc should not allow any recycle zinc to go unreported since the zinc in brass always remains in recovered brass alloys.

The old purchased scrap category shown in Table 4.5-1 includes several materials that will be included in the target and several that are not. The old die cast scrap, mainly rccovcred from automobiles and home appliances is included and is an area for increased recovery. The general zinc scrap includes old engravers plates and old zinc metal. The zinc-containing fractions from municipal incinerators are a category which might make a small contribution before 1987 . The 
TABLE $4.5-1$

\section{SELECTION OF RECOVERABLE MATERIALS}

ZINC INDUSTRY

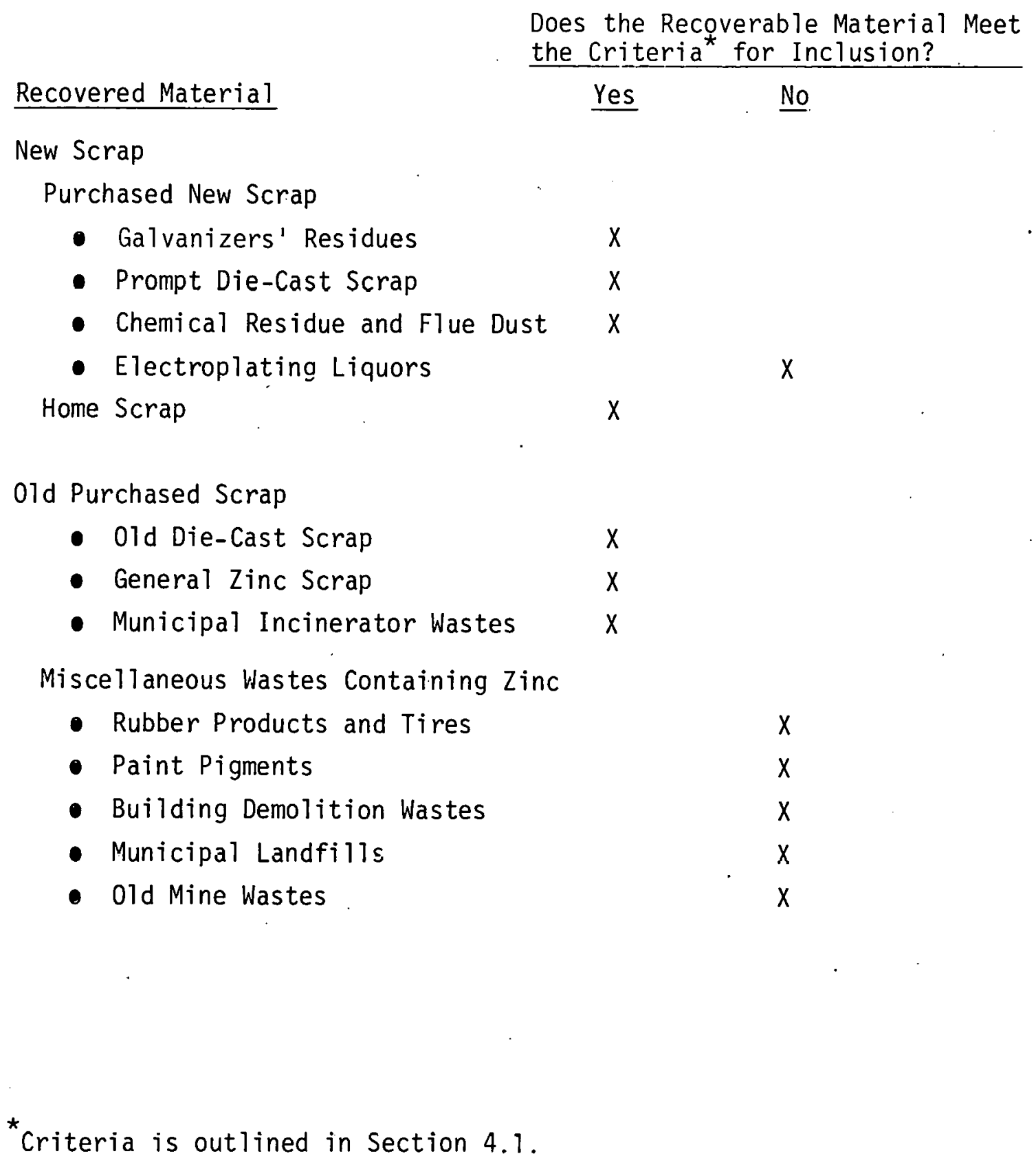


other miscellaneous wastes that contain zinc are not included in the target because they are either dissipative uses of zinc or they are not expected to be recovered before 1987. For example, the zinc oxide will not be recovered from rubber products until a process is developed to recover the energy or chemicals from the rubber. Paint pigments are a dissipative use of zinc, and building demolition wastes will not be sorted for metals because of labor costs. The zinc content of old municipal landfills or old mine wastes is not high enough to warrant its processing before 1987.

\subsubsection{Selection of Process Subdivision for Inclusion in the Target}

The historical consumption pattern for waste materials in each of the majur industry processes is given in Table 4.5-2. The different recoverable materials have historically gone to different types of processing depending upon the process and recoverable material constraints. One of the striking features of this table is that electrolytic reduction plants do not generally process any scrap except their home scrap. The major factor restricting the use of recovered materials in these plants is the necessity of avoiding contaminating metal ions in the electrolytic. bath solutions. Another feature of Table 4.5-2 is that secondary distillers process all types of scrap, both metallic and oxidized.

\subsubsection{Technical Considerations}

The technological factors controlling recycling can be discussed in terms of process constraints, product quality constraints, and recovered material quality constraints. The recoverable materials that pass all these constraints are the basis of the technological targets.

\subsubsection{Process Constraints}

Looking at the process contraints by class of recoverable material, the following statements can be made:

- The unly processes that generally recover zinc products from oxidized zinc materials are the vertical distillation retorts and the chemical and pigment plants. The types of scrap that are generally highly oxidized include the galvanizers's scrap, the chemical reoiduces, und the flue dusts.

- The foundries recover zinc from scrap that has a high metallic zinc content and controlled metallic impurities. They usually process their own home scrap and other inéw sinc die-cusl scrap.

- The secondary distillers process all zinc scrap, but can recover only the metallic zinc content of the scrap. They must sell the residues to other plants for recovery of the zinc values from the oxidized zinc content.

Table 4.5-3 shows the amounts of scrap utilized by each zinc producing process. The secondary distillers, vertical distillers, and chemical plants are the largest processors of scrap in that order.

If ull smelter capacity capable of processing scrap processed scrap rather than virgin ore, an additional 350,000 short tons of zinc scrap could be processed per year. Most of this additional capacity is in the primary vertical retorts, which could accept more scrap in their charge. The large excess smelting capacity indicates that processing is not a major restriction to increased zinc recycling. 
TABLE 4.5-2

RECOVERABLE MATERIAL - SOURCE - INDUSTRY MATRIX -

ZINC INDUSTRY

Types of Recoverable Materials

Process

Electrolytic

Reduction

Vertical Distillation

Retorts

Secondary Distillers

Foundries

Chemical and Pigment

Plants
Galvanizers' New Die Chemical Home 01d Die

Residues Cast Scrap Residues
General

Zinc Scrap 
TABLE $4.5-3$

\section{CONSIJMPTION OF RECOVERABLE NATERIALS - 1976}

ZINC INDUST:YY

Types of Recovered Materials in Tons of Zinc Contained

Process

Galvanizers'

New Die

Chemical

Home

01d Die Cast

General

Residues Cast Scrap

Residues

Scrap

scrap

Scrap

Total

Electrolytic

Reduction

NA

NA

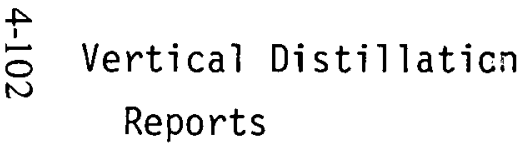

31,500

10,500

NA

43,000

Secondary Distillers

55,300

7,900

1,500

NA

53,3100

10,800

129,300

Foundries

NA

2,200

2,200

Chemical and Pigment

Plants

8,300

22,700

NA

0

31,000

NA: Data nat availabie.

Source: Estimates based on unpublished Tables 13, 14, 15 for Zinc to te in the 1976 Mineral Yearbook, Vslume I, Metals, Minerals and Fuels, U.S. Department of the Interior, Bureau of Mines. 


\subsubsection{Product Quality Constraints}

Very little recycle zinc is used by the die-cast industry except for home scrap because of the tight standards required for the main raw material, specification 49 zinc. This zinc can contain less than $0.001 \%$ of lead, tin, or cadmium, a degree of purity that is difficult to obtain from recycle zinc. The other applications, such as galvanizing and zinc oxide products, do not have the same stringent requirements. For example, prime western grade zinc with $98.5 \%$ zinc, the standard grade of zinc needed for galvanizing, can be produced from recovered materials. The presence of zinc oxides in the recoverable material is also not a major problem, since the vertical distillation retorts can reduce the oxides to metallic zinc.

\subsubsection{Recoverable Materials Quality Constraints}

The recoverable materials quality constraints are not very severe as long as there is some type of reducing distillation system available. All types of recoverable materials projected to be significant before 1987 could be processed.

\subsubsection{Economic Considerations in Recycling}

Economic considerations were not directly evaluated in this industry analysis. However, they are incorporated in assumptions used in the analysis and in the projection of historic trends.

The recovery of new materials, including galvanizers' residues and prompt die-cast scrap, has very favorable economics and is widely practiced. All galvanizers' residues are generally repurchased under contract by the zinc smelter or distiller supplying the zinc metal. Die-cast scrap also has a high value and is either reprocessed as home scrap or sold to dealers for subsequent use. With a stable consumption of zinc, the recovery of these new scraps should remain approximately at present levels. The recovery of chemical residue and flue dust is also fairly steady over the long term, although it is very sensitive to short-term swings in the zinc prices.

The great majority of old zinc scrap comes from the shredding of old automobiles and appliances. The resulting shredded materials are sorted into a ferrous fraction, a nonferrous fraction, and fluff by magnetic and air classifiers. The copper and brass are hand picked from the nonferrous fraction, leaving a mixture of aluminum, zinc, and solder. The zinc that is sweated from the remaining mixture and sold as ingot makes up the bulk of the old general zinc scrap. If the aluminum is separated from the zinc and solder by heavy media separation, the zinc and solder go into the old die-cast scrap category.

Automobiles scrapped in 1978 contain about 250,000 short tons of zinc die castings. Because new cars contain less zinc, those scrapped in 1987 will have only 125,000 short tons of zinc. More efficient recovery, however, could still meet a 1987 target of 70,000 short tons per year. This target is a growth rate of $3 \%$ annual increase of zinc from die-cast scrap. However, the level of 70,000 short tons per year of required old die castings predicted for 1987 should start dropping by 1990 as automobiles built in the very late 1.970's reach the shredders in significant numbers.

The other uses of zinc, such as galvanizing, rubber products, and paints are largely dissipative uses where the zinc is not generally recovered. The only exception is some zinc from galvanized steel recovered from electric arc furnace dusts. 


\subsubsection{Special Considerations}

Zinc is a metal with very mature types of demand patterns. It is unlikely that any large new uses or new regulatory pressures will shake the zinc industry before 1987. All zinc markets face competition from other metals such as aluminum and from plastics, which should severely limit any significant growth for zinc. However, zinc has sufficient advantage in price and properties to ensure its continued use in most existing applications. The consumer's perception of a metal product as being more durable than plastic and the acceptance of new thin-wall die-cast technology should help stabilize the important die-cast market.

The output of zinc products should not change dramatically from present levels before 1987 . By 1976 all of the older, marginal, and more polluting horizontal retort plants had been shut down. Some form of both electrolytic and pyrometallurgical reduction should survive to 1987 .

\subsubsection{Target Estimation}

As discussed in Section 4.5.5, increased recovery of zinc will center on old die castings. The recovery rate for old die casting should increase from a 1973-1976 average of 49,60n shnrt tonns per year to 70,000 short tons per year by 1987 . This increase in recovery coupled with a decrease in zinc content of automobiles would raise the proportion of old automobile die castings recovered from $20 \%$ in 1976 to $64 \%$ in 1987 . The other categories of recoverable materials should rcmain fairly constant if zinc consumption remains fairly level until 1987. The recovery target would then increase from $33 \%$ of production in 1976 to $36 \%$ of production in 1987.

\subsubsection{Sensitivity of Target to Key Factors}

Table 4.5-4 shows the target in units selected by DOE for the target, i.e., the ratio of purchased scrap (prompt industrial and old) to total shipments or production of the primary and secondary industries. The target of $36 \%$ recovery of the domestic zinc smelted by 1987 will depend on galvanizer zinc consumption, the rate of increase of automobile shredder sources with the ability to separate out the nonferrous fractions, any increase in the recovery of flue dust and cliemical residues, and domestic production rates. Since new galvanizers' scrap accounts for $49 \%$ of the $198^{\prime} /$ target, any major change in galvanized steel production would directly affect the overall zinc target. Several conflicting forces tend to obscure the actual level of recovery of new galvanizing residues by 1987 . Positive factors include predicted increased use of galvanized sheet in automobiles, galvanized rebar steel, and post-fabrication galvanized steel. Negative factors on zinc consumption include the penetration into the galvanizing market of steel sheet galvanizcd only on one side and the use of aluminum/zinc alloy (Galvalume) for galvanizing. The projected $29 \%$ of target represented by old die casting could change, depending on the technology for the separation of the nonferrous fraction from automobile shredders. Increased adoption of new methods for separating nonferrous at the shredder could produce a purer zinc fraction that would be a mure desirable recovered material. Based on historical patterns, the recovery of zinc from flue dust could fluctuate by about 30,000 short tons per year, depending on the price of zinc. The higher prices for zinc relative to the general price index would tend to lead to higher recovery rates. The final important assumption is that the domestic smelting of zinc in both primary and secondary smelters will remain constant for the next ten years. It is expected that any smelter capacity retired will be replaced, but that the economics in the industry may not justify much expansion of capacity. 
TABLE $4.5-4$

RECOVERED MATERIAL TARGET FOR ZINC INDUSTRY

(1987).

$\frac{\text { Recovered Material* }}{\text { Domestic Primary \& Secondary Production }} \times 100=36 \%$

* Purchased scrap, i.e., prompt industrial and obsolete scrap.

\subsection{LEAD}

\subsubsection{Selection of Recoverable Materials}

The scrap materials considered for inclusion in target selection are presented in Table 4.6-1. They are broadly grouped as new scrap, old scrap, slags, and dusts. Each category of scrap was assessed using the selection criteria (see Section 4.1) to determine whether it would contribute significantly to recycling in the lead industry by 1987 .

New scrap is composed of purchased drosses and residues that result from melting, smelting, refining, and manufacturing of lead and lead products (principally batteries and TEL). Drosses and residues normally contain various impurities and must be refined for reuse; they normally are sold to a reprocessor. Home scrap (or runaround scrap) also results from manufacturing operations and is generally in the form of lead metal. It requires only remelting for reuse and is normally recycled within the plant and is not sold. Home scrap is not included in target selection due to lack of data.

Old scrap, or post-consumer scrap, is broken down into the major categories by which scrap is normally sold or traded; battery plates, cable lead, soft lead, hard lead, type metal, babbit, and solders. All of the old scrap categories are in target selection.

Slags include secondary reverberatory slag, secondary blast furnace slag, and primary blast furnace slag. Secondary reverberatory slag contains significant quantities of lead and antimony and is normally recycled to a blast furnace; however due to lack of data it is not included in the target. Because of the low lead content of secondary blast furnace slag, it is normally dumped. A small quantity of secondary blast furnace slag is recycled to the blast furnace. It is used as a slagging agent however, not for its lead content. Because secondary blast furnace slag contains little recoverable lead and is not substitutable for virgin ore, it is excluded from this analysis. Primary blast furnace slag is normally dumped. Because of its low lead content, this slag will probably not be recycled by 1987 and, therefore, is not included in the target. The high sulfur matte from secondary blast furnace smelting of battery plates is normally dumped. Because it is produced in very small quantities and it is unlikely that it would be reprocessed for its lead content by 1987 , it is also excluded from this analysis.

Dusts are mainly from air pollution control equipment and are generally recycled because of their lead content. However, due to lack of data, neither primary nor secondary dusts are included in the target. 
TABLE $4.6-1$

SELECTION OF RECOVERABLE MATERIALS - LEAD INDUSTRY

Material

New Scrap:

Drosses and Residues

Home Scrap

01d Scrap:

Battery Plates

Cable Lead

Soft Lead

Hard Lead

Type Metal

Mixed Common Babbit

Solders and Tinny Lead

Primary Blast Furnace Slag

Primary Blast Furnace Dust

Secondary Reverberatory Slag

Secondary Reverberatory Dust

Secondary Blast Furnace Slag

Secondary Blast Furnace Dust

Matte from direct Secondary Blast

Furnace Melting
Does the Recoverable Material meet the Criteria* for Inclusion?

Yes No

$x$

$x$

$x$
$x$
$x$
$x$
$x$
$x$
$x$

$x$

$x$

$x$

$x$

$x$

$x$

$x$

* Criteria is outlined in Section 4.7 . 


\subsubsection{Selection of Process Subdivisions for Inclusion in the Target}

The historical consumption pattern for waste materials consumed by the primary and secondary lead industries is given in Table 4.6-2. The different recoverable materials (RM) have historically gone to different types of processing, depending upon the process and RM constraints. Primary blast furnaces use very little, if any, recoverable materials other than the small quantities of dusts, drosses, and skimmings generated in the plant. Secondary blast furnaces or reverberatory/blast furnace combinations can treat most wastes including oxides. Kettles can treat a variety of metallic lead materials but cannot handle wastes which require refining.

\subsubsection{Technical Considerations}

\subsubsection{Process Constraints}

The blast furnace is the principal process in the primary lead industry that can handle recoverable materials. The blast furnace is an efficient reducer (metallic oxides to metal) and could, therefore, process a wide range of recoverable materials including oxidized materials, dust, drosses, skimmings, etc. It could also be used to melt metallic scrap, although it is not designed for this use. The blast furnace reduces to metal most of the impurities found in the recoverable materials charge. Since the primary industry, for the most part, produces pure lead, these impurities will have to be removed from the lead by refining before use.

The blast furnace used by the secondary lead industry has process characteristics similar to those of the blast furnaces used in the primary industry. Reduction of impurities to metal is an advantage in this case, because of the difference in product and product specifications, i.e., alloys instead of pure lead. Unlike the primary blast furnace, the secondary blast furnace is used almost entirely to process recoverable material. Its ability to reduce to metal other elements in the recoverable materials (notably antimony), along with the lead, is a desirable feature for the secondary industry, which produces, for example, antimonial lead from high-antimony recoverable materials. A possible constraint on blast furnaces (both primary and secondary) is that very fine recoverable materials (e.g., dusts) must be agglomerated before use to avoid being blown out of the furnace.

The reverberatory furnace is employed only in the secondary lead industry. The furnace, even with furnace atmosphere control, is essentially a non-reducing process. In the secondary lead industry, reverbs are often used in conjunction with a blast furnace to process recoverable materials that contain both metallic lead and oxides. The recoverable material charge is melted in the reverberatory furnace, producing metallic lead and a slag layer containing any oxidized material (e.g., lead, antimony). The slag layer is reduced in the blast furnace, producing metallic lead (or alloy). Without the blast furnace, the reverb is extremely limited and can only process recoverable materials that contain metallic lead.

The kettle.is essentially a melter and can handle only scrap materials requiring melting only. The kettle is also used for refining operations. Because of heat transfer considerations and because kettle melting/refining is a batch operation, kettle melting is used only on small batches of scrap. 
TABLE 4.6-2

$\frac{\text { SCRAP CONSUMFTION IN THE LEAD INDUSTRY (1970-1976) }}{\text { (GroSS TONS) }}$

New Scrap:

Drosses \& Residues

Home Scrap

01d Scrap:

Battery Plates

Cable Lead

Soft Lead

Hard Lead

Type Metal

$\frac{p}{\infty}$

\begin{tabular}{|c|c|c|c|c|c|c|}
\hline 1970 & 1971 & 1972 & 1973 & 1974 & 1975 & 1976 \\
\hline 121,766 & 143,382 & 158,881 & 154,682 & 129,400 & 136,066 & 141,923 \\
\hline NA & NA & $N A$ & $N A$ & $N A$ & $N A$ & $N A$ \\
\hline 512,030 & 486,792 & 509,858 & 544,438 & 614,364 & 623,448 & 589,797 \\
\hline 26,544 & 29,455 & 26,775 & 26,397 & 45,507 & 50,569 & 47,738 \\
\hline 52,426 & 48,925 & 46,668 & 36,279 & 33,641 & 32,642 & 29,172 \\
\hline 19,015 & 27,254 & 27,641 & 51,992 & 54,778 & 26,912 & 30,395 \\
\hline 32,001 & 25,813 & 23,690 & 27,950 & 25,745 & 19,820 & 14,292 \\
\hline 11,799 & 11,665 & 11,049 & 13,534 & 12,025 & 8,552 & 7,839 \\
\hline 10,640 & 11,464 & 9,815 & 11,991 & 13,663 & 11,250 & 3,517 \\
\hline
\end{tabular}

Slag :

Secondary Reverberatory

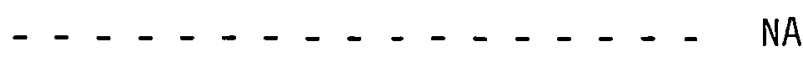

Dust :

Primary Blast Furnace

- - - - - - - - - - NA

Secondary Blast Furnace

- - - - . - . - . - - NA

Secondary Reverberatory

*includes consumption at foundries

NA: Not available.

Source: U.S. Bureau of Mines Minerals Yearbook, 1976.

Arthur D. Little, Inc. 


\subsubsection{Product Constraints}

Product constraints are set by the compositional limits imposed on the product by the applicable specification. Table 4.6-3 presents the specifications for pig lead; Table 4.6-4 presents the normal compositions for alloyed products.

\subsubsection{Recoverable Material Quality Constraints}

Constraints on the recoverable material are set by the product specifications, the technical limitations of the available equipment, and the chemistry of the process.

The recoverable material can be altered in the following ways:

- It can be melted.

- If oxides $(\mathrm{PbO})$ are present, they can be reduced to metallic lead in a blast furnace.

- If impurities cannot be removed, they can be diluted to acceptable limits by the addition of pure (or purer) metal.

- If higher levels of certain constituents are desired, the melt can be alloyed.

Normally, it is advantageous to match the feed material as closely as possible to the final product specifications. Thus, battery plates are normally recycled as antimonial lead, type metal is recycled to type, cable to soft lead, etc.

Theoretically, there is no technical limit to the amount of recoverable material a secondary plant can recycle, provided the product constraints are overcome.

However, on an industry level, the amount of recoverable material that can be recycled is limited by the availability of scrap materials. Based on historical recovery rates and the type of material under consideration, it is possible to estimate the maximum amount of material that can be recycled under foreseeable economic conditions. This information, along with projected growth rates for the various end uses, and knowledge of the lifetime (i.e., years from production to availability for recycle) allows the calculation of a theoretical maximum of production which is sustainable in the long run by the secondary producers, based on scrap availability.

For 1987, we estimate that the maximum secondary production based on scrap availability constraints is about $61 \%$ of total (primary plus secondary) production. The following assumptions were used in this calculation.

- Primary production will remain relatively constant at 700,000 short tons of lead annually.

- Demand for lead in batteries will grow at $4 \%$ annually.

- Demand for lead in metal products (except batteries and ammunition) will grow at 1 'i annually.

- Demand for lead in all other products together will grow little, if at all.

- In the long run, $75 \%$ of the lead used in batteries is recycled as scrap three years later. 
TABLE 4.6-3

\section{STANDARD SPEC-FICATIONS FOF: PIG LEAD}

Silver, max, percent

\begin{tabular}{|c|c|c|c|}
\hline $\begin{array}{c}\text { Corroding } \\
\quad \text { Lead* }^{\star} \\
\end{array}$ & $\begin{array}{l}\text { Chemical } \\
\text { Lead* }^{*}\end{array}$ & $\begin{array}{c}\text { Acid } \\
\text { Copper } \\
\text { Lead* }\end{array}$ & $\begin{array}{c}\text { Common } \\
\text { Desilverizec } \\
\text { Lead* }\end{array}$ \\
\hline 0.0015 & $0.020^{\prime}$ & 0.002 & 0.002 \\
\hline - & $0.00 \hat{c}$ & - & - \\
\hline 0.0015 & 0.080 & 0.080 & 0.0025 \\
\hline - & $0.04 C$ & 0.040. & - \\
\hline 0.0025 & - & - & - \\
\hline 0.002 & 0.002 & 0.002 & 0.005 \\
\hline 0.001 & 0.001 & 0.001 & 0.002 \\
\hline 0.002 & 0.002 & 0.002 & 0.002 \\
\hline 0.050 & 0.005 & 0.025 & 0.150 \\
\hline 99.94 & 99.90 & 99.90 & 99.85 \\
\hline
\end{tabular}

Silver, min, percent

Copper, max, percent

Copper, min, percent

Silver and copser together, max, percent

Arsenic, antimcny and tin together, max, percent

Zinc, max, percent

Iron, max, percent

Bismuth, max, percent

99.94

99.90

99.90

99.85

*NOTE: Corroding lead is a designation that has been used in the trade far many years to describe lead refined to a high degree of purity. Chemical lead has been used in the trade to describe the undesilverized lead produced from Southeastern Missouri ores. Acid-copper lead is made by addinc copper to fully refined lead. Common desilverized lead is a designation used to describe fully refined desilverized lead. Chemical analyses to be made in accordance $w^{-}$th methods prescribed in A.S.T.M. Designation E3T.

Source: Metal Statistics, 1977. 
TABLE $4.6-4$

COMPOSITION OF LEAD ALLOYS

$\ldots \ldots$ Percent - . . . . . . . -

Name

Babbitt, lead-antimony, No. 6

$\mathrm{Pb} \mathrm{Sb} \quad \mathrm{Sn} \mathrm{Cu} \mathrm{Ca} \quad \mathrm{Bi} \mathrm{Cd}$

Babbitt, lead-antimony,

No. 12

Cable sheathing, leadantimony

$\begin{array}{llllllll}63.5 & 15 & 20 & 1.5 & - & - & - & 0.15\end{array}$

$89.310-5 \quad 0.5 \quad-3 \quad-\quad-0.20$

$90.0 \quad 1.0$

Cable sheathing, leadcalcium

99.9

$\begin{array}{llll}- & - & - & 0.1\end{array}$

Fusible plug alloy, m.p., $68^{\circ} \mathrm{C}$

25.

$-\quad 12.5$

$-\quad 50.0 \quad 12.5$

Fusible plug alloy, m.p., $100^{\circ} \mathrm{C}$

Hard 1ead, $6 \%$ antimony

Hard 1ead, $12 \%$ antimony

Pewter

Shot

Solder, common

Solder, plumber's

Terne, low tin

Terne, high tin

Type meta1, foundry

electroytype

stereotype

$\begin{array}{lccc}20.0 & - & 40.0 & - \\ 94 & 6 & - & - \\ 88 & 12 & - & - \\ 10 & 10 & 79.8 & 0.2 \\ 94 & 6 & - & - \\ 50 & - & 50 & - \\ 60 & 2.5 & 37.5 & - \\ 75 & - & 25 & - \\ 50 & - & 50 & - \\ 62 & 24 & 14 & - \\ 94 & 3 & 3 & - \\ 81 & 14 & 5 & -\end{array}$

Source: Bray, J. L., Non-Ferrous Production Metallurgy. John Wiley \& Sons, Inc. New York, New York, 1947. 
- In the long run, $40 \%$ of the lead used in metal products is recycled ten years later.

- On the average, drosses amount to about $15 \%$ of the lead consumed in batteries in the same year.

- Net scrap exports will be zero.

\subsubsection{Economic Considerations}

Econometric modeling was not used to explicitly evaluate the economics of using recovered metals in this industry analysis. However, economic considerations are incorporated in assumptions used in the analysis and in the projection of historic trends.

Figure 4.6-1 presents data for the ratio of secondary to total production for the period 19701976 and a least-squares fit to that data. As can be seen, if historic trends continue, secondary production may reach $63 \%$ of total production by 1987 ,

The changeover to maintenance-fiee balteries may affect, the profitability of the secondary leaci industry. Traditionally, antimonial-lead battery plates (about 7\% antimony) have been produced by the secondary producers who purchase antimonial lead scrap at the cost of the lead and sell the antimony at a profit. With the introduction of maintenance-free batteries, the plities are being produced with low-antimony or calcium-lead alloys. With these alloys, the secondary producers lose the antimony credit (calcium is not recoverable with current technology) and also must produce costlier pure lead for the battery plates. The speed at which maintenance-free batteries penetrate the market and the type of alloy ultimately used for the plates may affect the profitability of the secondary industry as well as the supply structure of the lead industry (i.e., the cost to secondaries may be increased vis-à-vis the primaries).

\subsubsection{Special Considerations}

Significant baseline structural changes in the II.S. lead industry may result from dccreased demand foi lead lse:'isse of EPA regulations, the changeover from anlimunial-lead to ralrinm. lead maintenance-free batteries (discussed in Section 4.6.4), and the economic impact of proposed EPA and OSHA regulations which could potentially result in many plant closings and a lower rate of utilization of recovered materials.

'I'wo end-use markets, pigments and rhemicals, will probably cxperiente siguificunl du mand reductions over the next 5-10 years. Chemicals demand will decrease as a result of EPA regulations limiting the amount of TEL (about $99 \%$ of chemicals) in gasoline. Similarly, the demand for lead oxides in pigments will decrease as a result of various regulations concerning the lead content of paint. Demand reduction in these two end-use sectors will decrease lead demand proportionately. Most of the lead consumed in pigments and chemicals is refined soft lead and has historically come primarily from the primary industry (about two-thirds). Since primary and secondary lead are technical substitutes in most cases, this decrease in demand for soft lead may cause some market reorganization.

Finally, the outcome of proposed EPA air and OSHA air regulations may adversely affect both primary and secondary producers in the lead industry. The final economic outcome of these regulations is unknown at this time. 


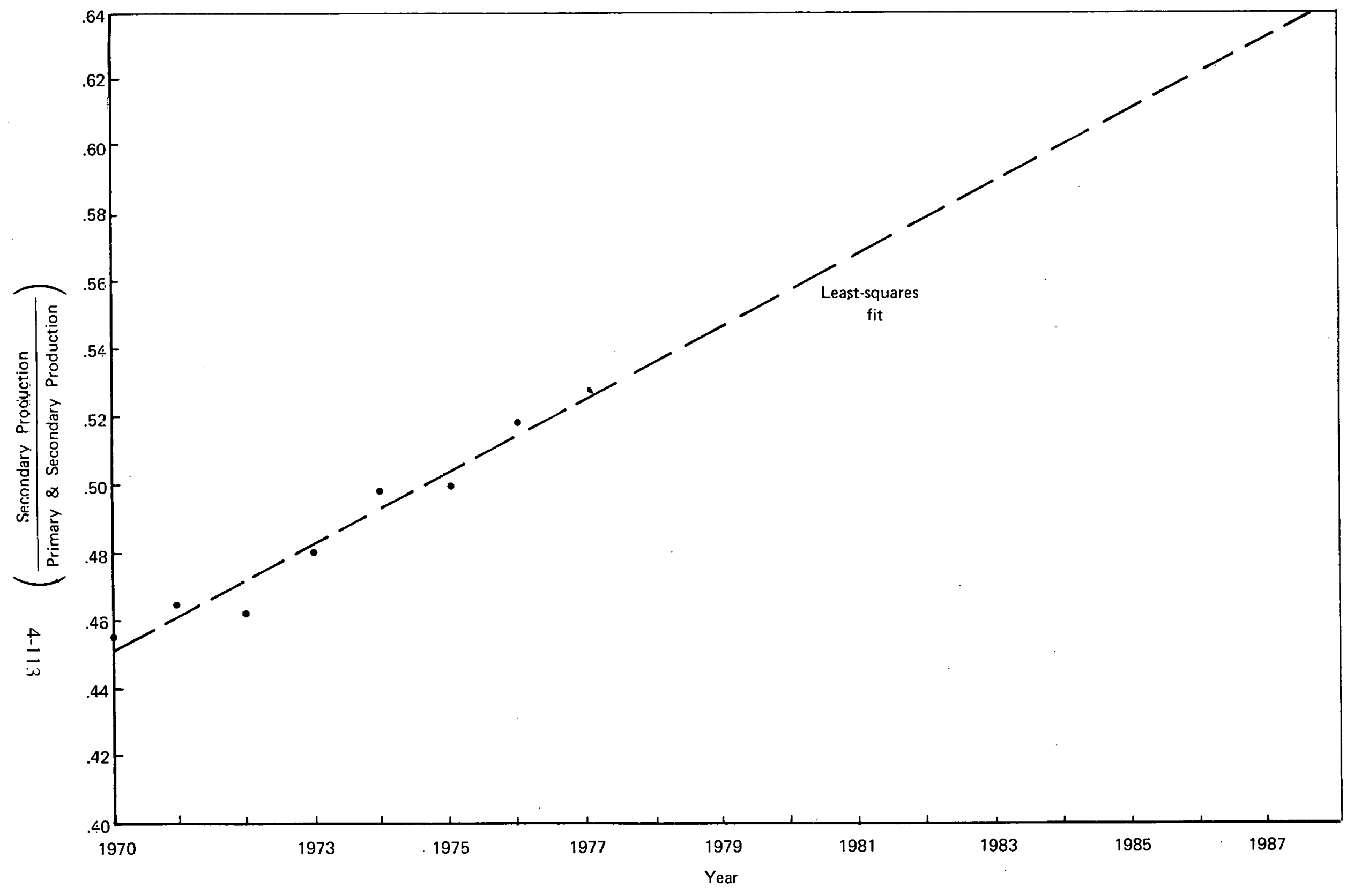

FIGURE 4.6.1 SECONDARY PRODUCTION RATIO - 1970-1976 


\subsubsection{Target Estimation}

The recycling target for the lead industry has been estimated based upon the following information and assumptions:

- There will be no significant use of recoverable material in the primary industry by 1987.

- The secondary industry uses recoverable material as $100 \%$ of its raw material.

- Based on DOE guidelines, the recycling target has been defined as the percentage of recovered material to primary plus secondary production (in net short tons).

- The capacity of the primary industry will remain at its 1976 level. Because of the lead-time requirements for mine/mill/smeltor/rcfincry, no new capacily will cume onstream by 1987. The net effect of any additions to capacity at existing smelters will be offset by capacity decreases caused by regulations.

- In the long tcrm, maximum capacity utilization by the primary industry is about $86 \%$ or 700,000 shurt tons of lead annually.

- Secondary capacity can be increased in a relatively short (several years) period of time.

- 'The changeover to maintenance-free batteries will not adversely affect the secondary industry.

- The demand reduction in chemicals and pigments will not adversely affect the primary industry.

- Based on scrap availability, the maximum secondary production of lead is $61 \%$ of total production.

- Based on historic projections, secondary production might increase to $63 \%$ of total production, without technical constraints.

- Total demand for lead will increase by 1987 ; demand in batteries will intredse at 4 in annually, and in metal producly at $1 \%$ aniiually.

- Net scrap exports in 1987 will be zero.

Based on this information, Table 4.6-5 shows the target in units selected by DOE. i.e., recóvered material as a percent of primary and sernndary production.

\subsubsection{Sensitivity of Target to Key Factor}

In developing the recycling target for the primary and secondary lead industry, it was necessary to make a variety of plausible assumptions concerning the evolution of the industry between 1976 and 1987. It was beyond the scope of this analysis to evaluate the effects of alternative assumptions.

The extent to which these assumptions hold true over the next eight years will affect the validity of the target; to the extent that these assumptions do not hold true, the larget should be modified. 
TABLE 4.6-5

$\frac{\text { RECOVERED MATERIAL TARGET FOR LEAD INDUSTRY }}{\underline{(1987)}}$

Recovered Material*

Domestic Primary \& Secondary Production

$\times 100=60 \%$

* Purchased scrap, i.e., prompt industrial and obsolete scrap.

The assumptions used in target estimation fall into two broad categories and were evaluated somewhat differently. The assumptions concerning the environment (scenario) within which the industry will evolve (e.g., effect of the introduction of maintenance-free batteries) could only be judged qualitatively based upon our knowledge of the industry. Numerical assumptions concerning the growth of the industry within this scenario (e.g., growth rate of demand for lead in batteries) were evaluated analytically using the economic concept of elasticity (i.e., the percentage change in the value of interest divided by percentage change of the variable in question). For example, an elasticity of 1.0 for the growth rate of battery lead demand implies that a $1 \%$ change in growth will change the target by $1 \%$; an elasticity of 0.5 implies a $1 \%$ change will cause a $0.5 \%$ change in the target, etc. In other words, the lower (relative to 0 ) the elasticity, the less sensitive the result to the variable in question.

There are four critical assumptions vis-à-vis scenario development: long run demand growth is $1.8 \%$ annually, net scrap exports are zero, maintenance-free batteries will not adversely affect the secondary industry, and the decrease in lead demand for TEL and pigments will not adversely affect the primary industry. The last two assumptions have been discussed in Section 4.6.5 : Special Considerations.

Because of the large amount of lead that is potentially recoverable after consumption, if demand for lead products does not continue increasing, scrap will be added tu the scrap pool, increasing its size. This, in turn, would tend to decrease the price of scrap and give secondary producers a cost advantage vis-à-vis the primaries. The minimum growth rate (based on 1976 consumption and the scrap availability equation) required to avoid this problem is $1.5 \%$ annually to 1987. This assumes that domestic producers can undersell imported metal. If imported metal remains at 1976 levels, the required growth is $2.2 \%$. If this overall level of growth is not obtained by 1987 , the target will be inaccurate, with the direction of the error depending upon where demand constraints occur. This analysis assumed an annual growth rate of $1.8 \%$ (as indicated by the Bureau of Mines) and surie displacement of imports.

Scrap exporters compete directly with secondary producers for lead scrap from the scrap pool. Therefore, scrap exports represent lost production to the secondaries (if the scrap is exported it cannot be used domestically) and their output in the long run will be reduced accordingly. This analysis assumed that by 1987 , net scrap exports of lead will be zero. If they are not, the target will be increased if there are net imports, or decreased if there are net cxporte. 
The marginal sensitivity of the target to the individual growth rates used in the scrap availability equation was evaluated relative to the projected 1987 data; the resultant elasticities are presented below, and expressed as:

$$
\left(\frac{\% \text { Change in Target }-\frac{\mathrm{P}_{2}}{\mathrm{P}_{1}+\mathrm{P}_{2}}}{\% \text { Change in Variable }}\right)
$$

$\underline{\text { Variable }}$

$P_{1}$

$\mathrm{K}_{\mathrm{B}}$

$i_{B}$

$K_{\mathrm{D}}$

$\mathrm{K}_{\mathrm{M}}$

$\mathrm{i}_{\mathrm{m}}$

\section{Elasticity}

0.39

0.31

0.12

007

0.02

0.00

where:

$P_{1} \quad=$ Domestic primary lead production.

$\mathrm{P}_{2} \quad=$ Domestic secondary production.

$\mathrm{C}_{\mathrm{B}} \quad$ = Consumption of lead in batteries.

$\mathrm{K}_{\mathrm{B}} \quad=$ Fraction of $\mathrm{C}_{\mathrm{B}}$ which is ultimately recycled.

$\mathrm{i}_{\mathrm{B}}=$ Annual growth rate of $\mathrm{C}_{\mathrm{B}}$.

$\mathrm{K}_{\mathrm{D}} \quad=$ Fraction of $\mathrm{C}_{\mathrm{M}}$ which is recycled as dross or residue.

$\mathrm{C}_{\mathrm{M}}=$ Consumption of lead in metal products, but not batteries, annunitiun, or brass or bronze.

$\mathrm{K}_{\mathrm{M}}=$ Fraction of $\mathrm{C}_{\mathrm{M}}$ which is ultimately recycled (old scrap).

$i_{\mathrm{M}} \quad=$ Annual growth rate of $\mathrm{C}_{\mathrm{M}}$.

As can be seen, the most, critical assumption is that primary production will remain al 700,000 short tons annually. For each 7,000 short ton difference (1\%), the target $(0.60)$ wnild change by $0.00234(0.39 \%)$. The second critical assumption is that $K_{\mathrm{R}}$ the ultimate recovery rate for batteries, is 0.75 . For each 0.0075 difference in $K_{B}(1 \%)$, the target would change by $0.0 n 19$ $(0.31 \%)$. 'T'he other variables have relatively little effect on the target, given their precision. 


\section{REFERENCES}

\section{REFERENCES: SECTION 4.2 FERROUS}

1 Assessment of Industrial Hazardous Waste Practices in the Metal Smelting and Refining Industry, Volume III, Calspan, April 1977.

2 An Overview of Steel Mill Dust Recycling Activity, Internal Memorandum Report by Arthur D. Little, Inc.

3 United States Steel Corporation, The Making, Shaping and Treating of Steel, H.E. McGannon, 1971.

4 U.S. Bureau of Mines Information Circular 8771, Energy Use Patterns for Metal Recycling, C.L. Kusik and C.B. Kenahan, 1978.

5 The Use of Steelmaking Slag as a Sinter Flux, M.R. Faigen, Applied Research Laboratories, U.S. Steel Corporation.

6 An Econometric Analysis of the Demand and Supply for Scrap Iron and Steel, (Unpublished Ph.D. Dissertation by R. Shriner, Indiana University, 1974).

7 The Economics of Ferrous Scrap Recycling, (Unpublished Ph.D. Dissertation by J. PlaterZyberk, Drexel University, 1972).

8 Purchased Ferrous Scrap: United States Demand and Supply Outlook, Fordham University Report to AISI, 1976.

9 Price-Volume Relationships for the Supply of Scrap Iron and Steel: A Study of the Price Elasticity of Supply, Report to Metal Scrap Research and Education Foundation by R. Nathan Associates, January 1978.

10 Mathematical Modeling of Raw Materials and Energy Needs of the Iron and Steel Industry in the U.S.A. Phase II. Report to the U.S. Bureau of Mines by J.F. Elliott, April 1975.

11 The Processing Capacity of the Ferrous Scrap Industry, Report to Metal Scrap Research and Education Foundation by Battelle Columbus Labs., August, 1.0, 1976.

12 AISI Annual Statistical Reports, 1960-1977.

13 Predicasts, 1978.

14 Private communications with Dr. B. Bovarnick, independent consultant.

15 Iron and Steel Engineer, Increasing Scrap Usage by the L-D Process - Theory, Practice and Prospects, J.K. Stone, June 1965. 
16 World Steel Industry Data Handbook, 33 Metal Producing, 1978.

17 Environmental Considerations of Selected Energy Conserving Manufacturing Process Options: Vol. III, Iron and Steel Industry Report, Report to the U.S. EPA by Arthur D. Little, Inc., December 1978.

18 The Operating, Economic and Quality Considerations of Scrap Preheating in the Basic Oxygen Process, Blast Furnace \& Steel Plant, W.F. Kemner, December 1969.

\section{REFERENCES: SECTION 4.3 ALUMINUM}

1 Aluminum, Preprint from 1976 Minerals Yearbook. U.S. Bureau of Mines.

2 A Study to Identify Opportunities for Increased Solid Waste Utilization, Vol. II to VII, Report to E'PA by Battelle Columbus Labs., 1972.

3 Recycling Opportunities and Challenges for the Aluminum Industry, Reynolds Metals Co., R.F. Testin, 1975.

4 Municipal Resource Recovery - What Impact Will It Have on Markets for Aluminum Scrap?, Reynolds Metals Co., Presented by R.F. Testin to NARI on March 10, 1978.

5 Recovery and Recycling of Automotive Aluminum, Society for Automotive Engineers, Inc., K.H. Dale, 1978.

6 Use of Aluminum in Automobiles - Effect on Energy Dilemma, Aluminum Association, April 1977.

7 Joint Aluminum/Copper Forecasting and Simulation Model, Prepared for U.S. Bureau of Mines by Synergy, Inc., June 1977.

8 Aluminum, Mineral Commodity Profile, U.S. Bureau of Mines. MCP-14, May 1978

9 The Recovery of Metal and Chemical Values from Aluminum Drosses, Alcan, International, Ltd., Han Spoel, 1975.

10 Furnace Dross - Its Fiormation and Recovery, Alumax, C.J. Moser.

11 Energy Efficiency Improvement Targets for Primary Metal Industries, SIC 33, Volume I. Draft Target Support Document, Battelle Columbus Labs., August 1976.

12 Energy Efficiency Improvement Targets for Primary Metal Industries. SIC 33. Volumc II, Draft Target System Document. Appendices, Battelle Columbus Labs., August 1976.

13 Communication from W. Pritsky, The Aluminum Association, May 8, 1979. 
REFERENCES: SECTION 4.4. COPPER

1 Economic Impact of Environmental Regulations on the U.S. Copper Industry, Report to the U.S. Bureau of Mines by Arthur D. Little, Inc., 1978.

2 A Study to Identify Opportunities for Increased Solid Waste Utilization, Vol. II to VII, Report to the U.S. EPA by Battelle Columbus Labs, 1972.

\section{REFERENCES: SECTION 4.6 LEAD}

1 U.S. Bureau of Mines, Mineral Commodity Profiles, Lead - 1977.

2 Preliminary Technological Feasibility, Cost of Compliance and Economic Impact Analysis of the Proposed OSHA Standard for Lead. Report to OSHA by John Short and Associates, January 4, 1977. 
Blank

$$
4-120
$$




\section{BIBLIOGRAPHY}

Albrecht, O.W. and R.G. McDermott. Economic and Technological Impediments to Recycling Obsolete Ferrous Solid Waste. EPA, October 1973.

Alter, H. Processes for the Recovery of Aluminum from Municipal Solid Waste. International Waste Equipment \& Technology Exposition, 1975.

Aluminum Association, Aluminum Statistical Review, 1976.

Aluminum Recycling Association. Use of Aluminum in Automobiles - Effect on Energy Dilemma. April 1977.

Amelung, E. Physical and Chemical Requirements for Scrap Deliveries to Steel Mills. Recycling Today, July 1976.

American Bureau of Metal Statistics, Inc. Nonferrous Metal Data, 1974, 1975, 1976.

American Institute of Mining, Metallurgical and Petroleum Engineers (AIME). Energy Use and Conservation in the Metals Industry. 104th AIME Annual Meeting, New York, February 16-20, 1975.

American Iron \& Steel Institute (AISI). Annual Statistical Report, 1976.

American Iron \& Steel Institute (AISI). Annual Statistical Report, 1977.

American Iron \& Steel Institute (AISI). Directory of Iron \& Steel Wurks of the U.S. and Canada, 1977.

American Iron \& Steel Institute (AISI). Directory of Iron \& Steel Plants, 1977.

Anderson, R.C. Economic Incentives for the Recovery of Secondary Lead. Resource Recovery \& Conservation, 1977.

Anderson, R.C. and R.D. Spiegelman. Impact of the Federal Tax Code on Resource Recovery. EPA, December 1976.

Annual Survey of Manufactures. Fuel and Electric Energy Consumed, 1976.

Annual Survey of Manufactures. General Statistics for Industry Groups and Industries (Including Supplemental Labor Costs), 1976.

Annual Survey of Manufactures. Value of Manufacturers' Inventories, 1976.

Annual Survey of Manufactures. Value of Product Shipments, 1976.

Annual Survey of Manufactures. Origin of Exports of Manufacturing Establishments, 1976. 
Ballance, J.B. Aluminum Update. Journal of Metals, October, 1978.

Baptizmanskii, V.I., et al. Fundamental Mechanisms Associated with the Melting of Steel Scrap in the Basic Oxygen Furnace. Steel in the USSR, February 1975.

Battelle, Columbus Laboratories. Energy Efficiency Improvement Targets for Primary Metal Industries. SIC 33. Vol. I. Draft Target Support Document. DOE. August 1976.

Battelle, Columbus Laboratories. Energy Efficiency Improvement Targets for Primary Metal Industries. SIC 33. Vol. II. Draft Target System Document. Appendices. DOE. August 1976.

Battelle, Columbus Laboratories. Energy Efficiency Improvement Target for SIC 34. Fabricated Metal Products. Vol. I. Draft Target Support Document. DOE. June 28, 1976.

Battelle, Columbus Laboratories. Energy Use Patterns in Metallurgical and Nonmetallic Mineral Processing (Phase 4 - Energy Data and Flowsheets High-Priority Commudities). Bureau of Miriés, June 27, 1976.

Battelle, Columbus Laboratories. Energy Use Patterns in Metallurgical and Nonmetallic Mineral Processing (Phase 5 - Energy Dala and Flowsheets, Intermcdiate - Priority Commodities). Bureau of Mines, September 16, 1975.

Battelle, Columbus Laboratories. Energy Use Patterns in Metallurgical and Nonmetallic Mineral Processing (Phase 7 - Summary of the Results of Phases 4,5 \& 6). Bureau of Mines, September 21, 1976.

Battelle, Columbus Laboratories. Energy Use Patterns in Metallurgical and Nonmetallic Mineral Processing (Phase 8 - Opportunities to Improve Energy Efficiency in Production of High-Priority Commodities Without Major Process Changes). Bureau of Mines, September 17, 1975.

Battelle, Columbus Laboratories. Energy Üse Patterns in Metallurgical and Nonmetallic Minteral Processing (Phase 9 - Areas Where Alternative Technologies Should be Developed to Lower Energy Use in Production of High-Priority Commodities). Bureau of Mines, August 25, 1976.

Battelle, Columbus Laboratories. The Processing Capacity of the Ferrous Scrap Industry. Metal Scrap Research and Education Foundation, August 10, 1976.

Battelle Memorial Insitute. A Study to Identify Upportunities for Increased Solid Waste Utilization, Vol. I - VII. EPA, 1972.

Bever, M.B. Recycling in the Materials System. Technology Review, February 1977.

Bonczar, E.S. An Economic Analysis of the Determinants of Metal Recycling in the United States: A Case St.udy of Secondary Copper. Bureau of Mines, May 1975.

Booz-Allen. An Analysis of the Abandoned Automobile Problem. Prepared for EPA, July 1973. 
Brinn, D.G. A Survey of the Published Literature Dealing with Steel Industry In-Plant Fines and Their Recycling. British Steel Corporation, August 1974.

Brooks, C. L. New Technology in Recovery and Reuse of Aluminum Scrap.

Brown, C. K. et al. Energy Analysis of Resource Recovery Options. Prepared for the Ministry of the Environment and the Ministry of Energy. Ontario Research Foundation, April 30, 1976.

Calspan. Assessment of Industrial Hazardous Waste Practices in the Metal Smelting and Refining Industry. April 1977.

Carney, D. J. Electric Furnace Steelmaking in the Next Decade. Journal of Metals, March 1974.

Carrillo, F. V. et al. Recovery of Secondary Copper and Zinc in the United States. Bureau of Mines, May 1974.

Coleman, R. T. et al. Final Report Pollution Control and Heat Recovery from Nonferrous Smelters Vol. I: Executive Summary. Radian Corp., February 28, 1977.

Commins, J. A. and V. Hathaway. Barriers to the Use of Secondary Metals. JACA Corp., August 1977.

Cooperman, R. M. Secondary Aluminum Shipment in First Quarter. Aluminum Recycling Association, July 31, 1978.

Cooperman, R. M. Shipments of Recycled Aluminum Update. Aluminum Recycling Association, November 8, 1978.

Copper Development Assoc. Annual Data 1975: Copper, Brass, Bronze.

Copper Development Assoc. Copper Supply \& Consumption, 1955-1974. 1975.

Coyle, B. H. and J. A. Koperski. Hydrometallurgical Separation of the Zinc-Base Fraction of Shredded Aulunubiles. Cunservaliun \& Recycling, Vol. 1, 1977.

Cutler, H. Snail Paced Progress Frustrates Year for Scrap Metal Industry. Institute of Scrap Iron \& Steel, (ISIS)January 1977.

Cutler, H. and G.S. Goldman. Transportation: Bugaboo of Scrap Iron Recycling. Vol. 7, No. 5. Environmental Science \& Technology, May 1977.

Dale, K.H. Recovery and Recycling of Automotive Aluminum. Society for Automotive Engineers, Inc., 1978.

Deily, R. L. Casting Raw Steel - U.S.A. Iron and Steel Maker, December 1977.

Dean, K. C. and J. W. Sterner. Metal Recovery by Dismantling of Scrapped Starter Motors, Auto Generators, and Alternators. Bureau of Mines, 1976. 
DeHuff, G. L. and T. S. Jones. Manganese, Mineral Commodity Profiles, MCP-7. U.S. Bureau of Mines, October 1977.

Dower, R. C. and R. C. Anderson. Futures Markets: An Alternative for Stabilizing Secondary Materials Markets? Resources Policy, December 1977.

Elliot, J. F. Mathematical Modeling of Raw Materials and Energy Needs of the Iron and Steel Industry in the U.S.A. - Phase I - A Model of the Raw Materials Requirements of the U.S. Steel Industry. Bureau of Mines, April 24, 1973.

Elliott, J.F. Phase II - Metallic Supply for Steelmaking - A Dynamic System. Bureau of Mines, April ?, 1975 .

Elliott, J.F. Future Raw Materials Needs of the American Steel Industry. Iron \& Steel Maker, April 1 $\mathbf{y}^{\prime} / \mathrm{b}$.

Elliott, J.F. Kecycling and Einergy Use in the Production of Metals, Abstract No. 297. The Electrochemical Society, May 16, 1975.

Faigen, M.R. The Use of Steelmaking Slag as a Sinter Flux, Applied Research Laboratories, U.S. Steel Corporation.

Federal Register. Proposed Criteria for Classification of Solid Waste Disposal Facilities, Vol. 43, No. 79. April 24, 1978.

Federal Register. Standards Applicable to Transporters of Hazardous Wastes, Part IV, Vol. 43, No. 83. $\Lambda$ pril 28, 1978.

Federal Register. Preliminary Notification of Hazardous Waste Activities, Vol. 43, No. 133. July 11, 1978.

Federal Register. Resource Recovery Project Development Grants Under the President's Urban Policy, Part VII, Vol. 43, No. 147. July 31, 1978.

Federal Register. Public Participation in Programs Under the Resource Conservation and Recovery Act, the Safe Drinking Water Act, and the Clean Water Act. Vol. 43, No. 152. August 7, 1978.

Federal Register. PSD Permit Denial, Resource Conservation and Recovery Act of 1976, Public Meeting, Vol. 43, No. 159. August 16, 1978.

Federal Register. State Solid Waste Management Plans, Guidelines for Development and Implementation, Part IV, EPA. August 28, 1978.

Federal Register. Vol. 44, No. 5. January 8, 1979.

Fernandes, J.H. Processing and Recycling: Producing End Products and Energy. Combustion, February 1977. 
Fink, D.A. Market Structure and Recycling in the Nonferrous Metals Industries. Resource Conservation, D.W. Pearce and I. Walter, eds., New York: New York University Press, 1977.

Fletcher, A.W. Review Lecture: Metal Recycling from Scrap and Waste Materials, A. 351. Proc. Royal Society, London, October 22, 1976.

Fordham University. Purchased Ferrous Scrap: United States Demand and Supply Outlook. Report to American Iron and Steel Institute, June 1977.

Gill, D. R. Exports of Ferrous Scrap. Iron and Steel Maker, March 1979.

Gordon, R. L. et al. Effective Systems of Scrap Utilization: Copper, Aluminum, and Nickel. Pennsylvania State University, July 1972.

Graham, W. O. Marketing and Equipment Design-Municipal Solid Waste-Ferrous Metal Recovery. Scrap Agc, June 1976.

Great Lakes Research Institute. Evaluation, Extraction, and Recycling of Certain Solid Waste Components. Report for EPA, 1971.

Gross. Energy Saving Recovered Materials Targets Guidance to Methodology. Internal Memorandum, U.S. Department of Energy. January 10, 1979.

Harwood, J. J. Recycling the Junk Car. Technology Review, February 1977.

Henn, J. J. Updated Cost Evaluation of a Metal and Mineral Recovery Process for Treating Municipal Incinerator Residues. Bureau of Mines, December 1975.

Hickman, H. L. Review of EPA's OSWMP Activities for Fiscal Year 1977. Waste Age, November 1976.

Higley, L. W. and M. M. Fine. Electric Furnace Steelmaking Dusts-A Zinc Raw Material. Bureau of Mines, 1977.

Hogan, W. T. Steel Demand, Capital Costs, and Imports: Impact on the Steel Industry's Capital Needs. Fordham University, October 1975.

Hogan, W. T. and F. T. Koelble. Purchased Ferrous Scrap- United States Demand and Supply Outlook. Fordham University Study for American Iron \& Steel Institute, June 1977.

Hogan, W. T. and F. T. Koelble. Ibid. Appendix I-1- Forecast of U.S. Steel Demand in 1982.

Institute of Scrap Iron and Steel. Identification of Opportunities for Increased Recycling of Ferrous Solid Waste. 1972.

Institute of Scrap Iron and Steel. FACTS: 32nd Edition, 1974 Yearbook. 1975.

Institute of Scrap Iron and Steel. Ihid. 33rd Fdition, 1975 Yearbonk. 1976. 
Institute of Scrap Iron and Steel. Ibid. 34th Edition, 1976 Yearbook. 1977.

Institute of Scrap Iron and Steel. Ibid. 35th Edition, 1977 Yearbook. 1978.

Iron Age. Classification by Firm, 1977 Steel Industry Financial Analysis. April 24, 1977.

Iron \& Steel Engineer. Statistical Highlights-1967-1976, U.S. Iron and Steel Industry. July 1977.

Jackson, D. V. The Recovery of Metals-General Considerations. Chemistry \& Industry, December 6,1975 .

Jacobi, J. S. Recovery and Reuse of Metals. Iron \& Steel International, June 1976.

Jones, T. S. Silicon, Preprint from the 1975 Bureau of Mines Minerals Yearbook.

Jones, T. S. Ferroalloys. Bureau of Mines Yearbook, 1976.

Kearney, A. T. Inc. Economic Analysis of Effluent Guidelines: Ferroalloys Industry. Report to EPA, June 1974.

Kearney, A. T. Inc. Ferrous Scrap Geographical Distributions Demand vs. Newly Available Supply 1975-1985. Report to Bureau of Mines, July 1976.

Kellogg, H. H. The Role of Recycling in Conservation of Metals and Energy. Journal of Metals, December 1976.

Kemner, W. F. The Operating, Economic and Quality Considerations of Scrap Preheating in the Basic Oxygen Process. Blast Furnace \& Steel Plant, December 1969.

Kotsch, J. A. et al. Developments in the Iron and Steel Industry, U.S. and Canada-1976. Iron \& Steel Engineer, February 1977.

Little, Arthur D., Inc. Steel and the Environment-A Cost Impact Analysis. Study for the AISI, 1.975.

Little, Arthur D., Inc. Economic Analysis of Pretreatment Standards for the Secondary Copper and Aluminum Subcategories of the Nonferrous Metals Manufacturing Paint Source Category. Report to EPA, October 1976.

Little, Arthur D., Inc. Environmental Considerations of Selected Energy Conserving Manufacturing Process Options: Vol. VIII, Alumina/Aluminum Industry. Report to EPA, December 1976.

Little, Arthur D., Inc. Preliminary Assessment of Woolworth Scrap Preheater. Report to ERDA, Scptcmbcr 6, 1977.

Little, Arthur D., Inc. Economic Impact of Environmental Regulations on the United States Copper Industry. Report to EPA, January 1978. 
Little, Arthur D., Inc. Energy Use Patterns for Metal Recycling. Final Report to U.S. Bureau of Mines, January 1978.

Little, Arthur D. Inc. Computer Search of Chemical Abstracts, Engineering Index and Metals Abstract (4,000 References). December 1978.

Little, Arthur D., Inc. Computer Search of NTIS Publications on Metal Recycling (700 References). December 1978.

MacKallor, J. A. and G. H. K. Schenck. Future U.S. Supplies and Demands for Lead. American Institute of Mining, Metallurgical and Petroleum Engineers (AIME).

Mahoney, L. R. and J. J. Harwood. The Automobile as a Renewable Resource. Resources Policy, September 1975.

Makar, H. V. and P. J. Gallagher. Deoxidation of Steel Using Waste Aluminizing Dross (A Feasibility Study). Bureau of Mines, July 1972.

Mantle, E. C. Advances in the Recovery of Waste Non-Ferrous Metals. Chemistry \& Industry, September 1976.

Manzone, M. G. Recycling Copper Scrap at United States Metals Refining Company. CIM Bulletin, August 1977.

Marketing Economics. Employment of SIC 33 Companies Arranged by 4 Digit SIC Classifications. 1977-1978.

Matyas, A. G. Utilization of Steelmaking Slag. Iron \& Steel Engineer, August 1978.

Mautz, E. W. The Ferrous and Common Nonferrous Metals Industries and Associated Scrap Metals-A Review. National Lead Co. of Ohio, November 1975.

McGannon, Harold, ed. United States Steel Corporation. The Making, Shaping and Treating of St.e.l. 9th Ed., 1971.

McManus, G. The View from '77: How Steel's Future Stacks Up. Iron Age, May 23, 1977.

Meier, P. M. et al. An Assessment of Wet Systems for Residential Refuse Collection: Summary Report. Curran Associates, August 1974.

Metal Progress. Steel Availability...Short and Long Term Aspects. September 1974.

Metals \& Materials. The Recovery of Secondary Copper- Its Technology \& Economics. September 1977 .

Midwest Research Institute. Base Line Forecasts of Resource Recovery, 1972 to 1990. Prepared for EPA, March 1975. 
Modern Casting. Iron-Steel Distribution in U.S.A. October 1977.

Morgan, J. D. World Distribution and Flow of Major Mineral Commodities. Bureau of Mines, April 28, 1976.

Morning, J. L. Chromium, Mineral Commodity Profiles. U.S. Bureau of Mines, MCP-1, May 1977.

Moser, C. J. Furnace Dross-Its Formation and Recovery. Alumax, San Mateo, CA.

Nathan, Robert R. Associates, Inc. Iron and Steel Scrap: Its Accumulation and Availability as of December 31, 1975. Report to Metal Scrap Research \& Education Foundation, August 22, 1977.

Nathan, Robert R. Associates, Inc. Ibid. Updated to December 31, 1977. August 25, 1978.

Nathan, Robert R. Associates, Inc. Price-Volume Relationships for the Supply of Scrap Iron and Steel: A Study of the Price Elasticity of Supply. Report to Metal Scrap Research \& Education Foundation, January 8, 1979.

National Association of Recycling Industries. Membership Directory, 1976-1977. July 1976.

National Center for Resource Recovery, Inc. Magnetic Separation: Recovery of Saleable Iron and Steel from Municipal Waste. March 1977.

Nicola, A. G. Blast Furnaces-U.S. \& Canada. Iron \& Steel Engineer, September 1978.

Nicola, A. G. Open Hearth Facilities in the U.S. Op. cit., October 1978.

Nicola, A. G. Electric Arc Furnace Shops in the U.S. and Canada. Op. cit., November 1978.

Nussbaum, A. I. Remelt Shop Systems for Aluminum Mill Scrap Recycling. Light Metal Age, April 1975.

Opie, W. R. Problems in Smelting Copper. Scrap Journal, pp. 52-54.

Organization for European Economic Co-Operation (OEEC). Zinc and Lead Smelting and Refining in the U.S.A. Technical Assistance Mission No. 85, Vol. II, January 1955.

Organization for European Economic Co-Operation (OEEC). Industrial Adaptation in the Primary Aluminum Industry, 1976.

Ostrowski, E. J. Recycling of Solid Waste Ferrous Scrap in the Blast Furnace. Minnesota AIME.

Ottmar, H. et al. Technical and Economic Effects of the Substitution of Scrap by Sponge Iron in the Arc Furnace. Stahl u. Eisen 97, July 28, 1977.

Page, T. Conservation and Economic Efficiency, Resources for the Future. Baltimore, John Hopkins University Press, 1977. 
Parfet, H. B. Manganese for Steelmaking: A Crisis of the Future? Iron \& Steel Maker, January 1975.

Penton Publications. Foundry File. 1977.

Phillips, T. A. An Economic Evaluation of a Process to Separate Raw Urban Refuse into its Metal, Mineral, and Energy Components. Bureau of Mines, 1977.

Pietrucha, W. E. and R. L. Deily. Steel Industry in Brief: Databook, U.S.A. 1977. Institute for Iron \& Steel, 1977.

Plater-Zyberk, J. The Economics of Ferrous Scrap Recycling. Unpublished Ph.D. Dissertation: Drexel University, 1972.

Powell, H. E. et al. Converting Stainless Steel Furnace Flue Dusts and Wastes to Recyclable Alloy. Bureáu of Mines, June 1975.

Predicasts Basebook. Predicasts Annual Cumulative Edition. Issue No. 72, 1978.

Predicasts Basebook-Iron \& Steel. 1978.

Predicasts Basebook-Slag: Iron \& Steel. 1978.

Predicasts Basebook. Computer Printout of Scrap Consumption in Ferroalloys Industry. 1978.

Reade, K.H. Recovery and Recycling of Automotive Aluminum, Society for Automotive Engineers, Inc., 1978.

Regan, W. J. et al. Identification of Opportunities for Increased Recycling of Ferrous Solid Waste. Institute of Scrap Iron and Steel, 1972.

Reuter, F. H. et al. A Cost-Effectiveness Analysis of Junk Vehicle Abatement Programs. CONSAD Research Corp. for Motor Vehicle Mfgrs. October 31, 1975.

Roscrow, W. J. Furnaces and Processes for Non-Ferrous Metal Recovery. Metallurgia and Metal Forming, August 1975.

Schloemann, E. Recovering Metal from Trash. Iron \& Steel International, June 1976.

Schottman, F. J. Silicon: Preprint from the Bureau of Mines Minerals Yearbook, 1976.

Short, John, and Assoc. Preliminary Technological Feasibility, Cost of Compliance and Economic Impact Analysis of the Proposed OSHA Standard for Lead. OSHA, January 4, 1977.

Shriner, R. An Econometric Analysis of the Demand and Supply for Scrap Iron and Steel. Unpublished Ph.D. Dissertation: Indiana University, 1974.

"

Silk, L. Lighter Cars Add Problems. Fconomic. Scene. New York Times, January 17, 1979. 
Sizemore, R. C. Lead Recyclers Face Market Shift. AMN-Batteries Section, April 1977.

Smith, M. F. Lead Batteries (Citations from the Engineering Index Data Base), August 1978.

Solow, R.M. The Economics of Resources or the Resources of Economics. The American Economic Review, Vol. 67, No. 1, February 1977.

Spendlove, M. J. Methods for Producing Secondary Copper. Bureau of Mines, 1961.

Spendlove, M. J. Recycling Trends in the United States: A Review. Bureau of Mines, May 1976.

Spoel, Hans. The Recovery of Metal and Chemical Values from Aluminum Drosses. Alcan Inter., Ltd., 1975.

Staker, W. L. and R. D. Groves. Use of Shredded Automobile Scrap for Copper Cementation. Bureau of Mines, 1976.

Stevens, B. J. Impact of the Federal Tax Code on Resource Recovery: A Condensation. Report by Columbia University for EPA, August 1977.

Stone, J. K. Joint Venture Iron and Steel Plants. Iron \& Steel Maker, June 1977.

Stone, J. K. Worldwide Roundup of Basic Oxygen Steelmaking. Iron \& Steel Maker, September 1977.

Strauss, S.D. Competition in the Non-Ferrous Metal Markets. Presentation before the Annual Meeting of the American Insitute of Mining, Metallurgical and Petroleum Engineers, Atlanta, GA, March 9, 1977.

Synergy, Inc. Joint Aluminum/Copper Forecasting and Simulation Model, Prepared for U.S. Bureau of Mines, June $1 y^{\prime} \%$.

Testin, R.F. Municipal Resource Recovery - What Impact Will it Have on Markets for Aluminum Scrap? Reynolds Metals Co., Presented to NARI on March 10, 1978.

Testin, R.F. Recycling Opportunities and Challenges for the Aluminum Industry. Reynolds Metals Company, American C'hemical Society Symposiumm, June 11, 1975.

'l'ownsend, N.A. A Keview of Kecent Developments in Scrap Preparation. British Steel Corp., April $19 \%$ '

Tress, J.E. and W.L. Hunter. Secondary Pig Iron from Shredded Auto Scrap. Bureau of Mines, November 1973.

United Nations. The Steel Market in 1977, U.N. ECE/ STEEL/23, 1978.

U.S. Bureau of Census. Annual Survey of Manufactures - General Statistics for Industry Groups \& Industries, 1976. 
U.S. Bureau of Mines. Minerals Yearbooks, 1974, 1975, 1976 (preprints).

U.S. Bureau of Mines. Energy Use Patterns in Metallurgical and Nonmetallic Processing (Phase 5 - Energy Data and Flowsheets, Intermediate Priority Commodities.) September 1975.

U.S. Bureau of Mines. Mineral Commodity Profiles, 1976 and 1977.

U.S. Bureau of Mines. Mineral Industry Surveys, 1976.

U.S. Bureau of Mines. Recycling Trends in the United States: A Review. May 1976.

U.S. Bureau of Mines. Commodity Data Summaries, 1977.

U.S. Bureau of Mines. Mineral Industry Surveys, 1970 through 1977.

U.S. Code Annotated, June 1978. Public Health and Welfare, 1977-1978. p. 845-858. No. 1.

U.S. Code Annotated, October 20, 1978. Title II Solid Waste Disposal Act. P.L. 89-272.

U.S. Code Congressional \& Administration News. President's Messages: National Urban Policy. No. 3. April 1978.

U.S. Department of Commerce. Annual Statistical Review, Metal Prices and Production as of December 31, 1977, Steel Production. Iron Age, January 1, 1978.

U.S. Department of Commerce. Annual Statistical Review. Metal Prices and Production as of December 31, 1978. Iron Age, January 1, 1979.

U.S. Department of Commerce. Legislative History of Solid Waste: 1976-1978, Resource Conservation and Recovery Act of 1976. P.L. 94-580, October 11, 1976.

U.S. Department of Commerce. Legislative History: Resource Conservation and Recovery Act of 1976, P.L. 94-576, October 11, 1976.

U.S. Deparlinent of Commerce. The Foundry Industry: A Current Overview of Factors Affecting the Availability of Castings for Project Independence and Suggested Actions to Alleviate Problems. March 1975.

U.S. Department of Energy. Industrial Energy Efficiency Improvement Program, Annual Report Support Document. Vol. II. June 1978.

U.S. Department of Energy. Solid Waste Reclamation and Recycling Part 3. Metals - A Bibliography with Abstracts. 1978.

U.S. Executive Office of the President, Council on Wage and Price Stability. Aluminum Prices 1974-1975. Staff Report, September 1976.

U.S. Executive Office of the President, Office of Management and Budget. Statistical Policy Division. Standard Industrial Classification Manual, 1972. 
U.S. Federal Energy Administration, Industrial Energy Conservation Program. Final Industrial Energy Efficiency Improvement Targets, Part II. June 9, 1977.

Wallace, John F. Foundries: A New Market for Reclaimed Ferrous Scrap. Recycling Today, March 1977.

Watson, G.A. The Ferroalloy Industry. Speech given at Ferroalloy Association 32nd Electric Furnace Conference, December 11, 1974. 22 pp.

Watson, G.A. The Future of the Ferroalloy Industry. Iron \& Steel Maker, May 1977.

Weismantel, G.E. Needs and Knowhow Boost Aluminum Recycle. Chemical Engineering, May 9, 1977.

Wentz, C.N. Trends in Recycling Scrap-Sources of Secondary Metals. Colorado Mining Association. 1976 Mining Yearbook.

West, N.G. Recycling Ferruginous Wastes: Practice and Trends. Iron \& Steel International, June 1976.

Westinform Service. Iron and Steel Scrap on the Ocean Routes up to 1980. January 1974.

Whalley, L. and V.F. Broadie. U.K. Metal Reclamation: Prospects for Improvement. Resources Policy, December 1977.

Whitten, H.O. \& Associates. Recyclamation: Rail Transport Economics of Substitutability of Recycled Scrap or Waste for Basic Raw Materials. DOT, December 1971.

Ziegler, R.C. et al. Environmental Impacts of Virgin and Recycled Steel and Aluminum. EPA, February 1974.

33 Magazine. World Steel Industry Data Handbook. 1978. 